Prepared in cooperation with the

New Jersey Department of Environmental Protection

\title{
Streamflow Characteristics and Trends in New Jersey, Water Years 1897-2003
}

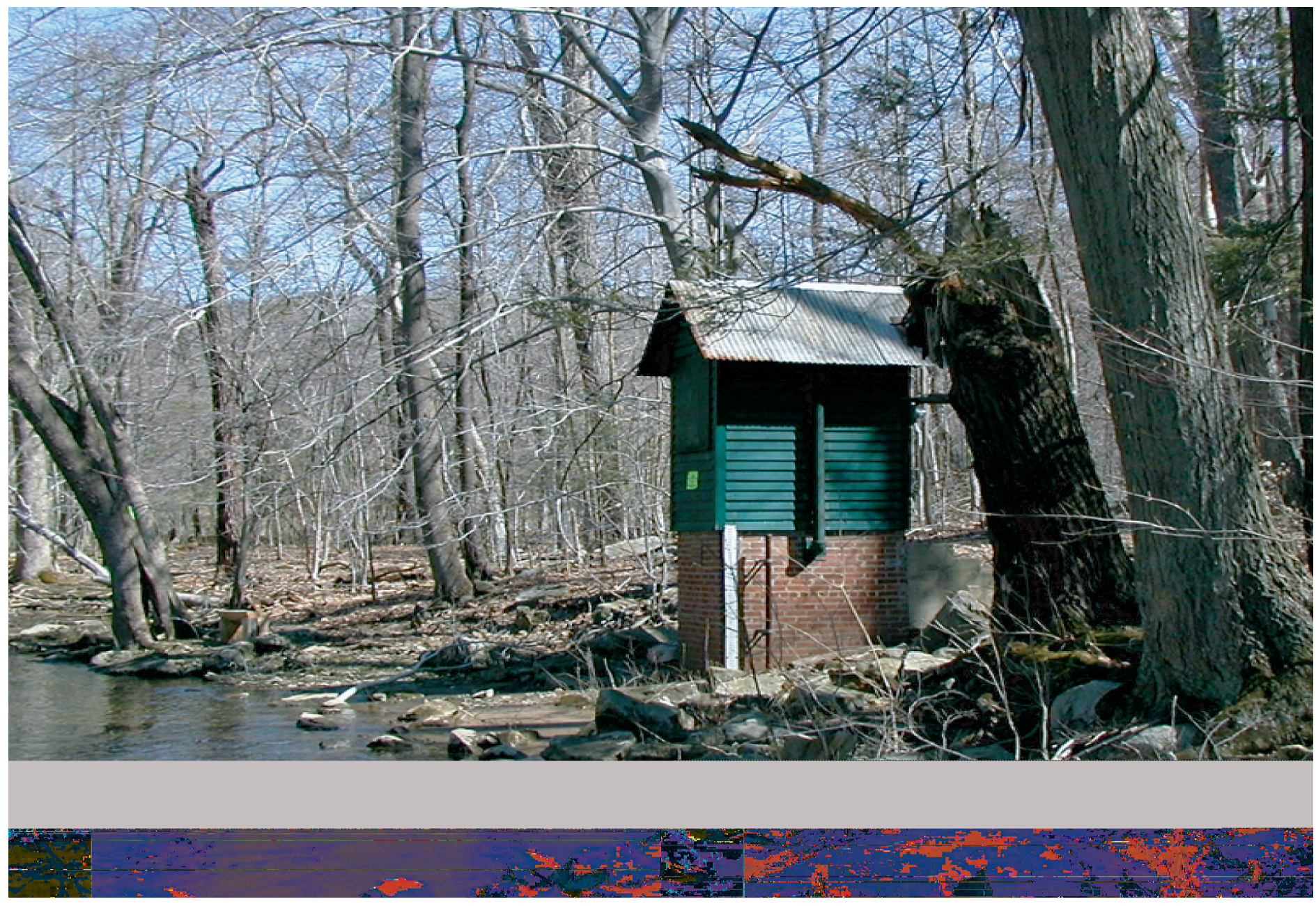

Scientific Investigations Report 2005-5105 
Cover. Photo on cover shows U.S. Geological Survey streamflow-gaging station 01396500, South Branch Raritan River near High Bridge, New Jersey. (Photograph by Rick Edwards, U.S. Geological Survey) 


\section{Streamflow Characteristics and Trends in New Jersey, Water Years 1897-2003}

By Kara M. Watson, Robert G. Reiser, Steven P. Nieswand, and Robert D. Schopp

Scientific Investigations Report 2005-5105 


\title{
U.S. Department of the Interior \\ Gale A. Norton, Secretary
}

\section{U.S. Geological Survey \\ P. Patrick Leahy, Acting Director}

U.S. Geological Survey, Reston, Virginia: 2005

\author{
For sale by \\ U.S. Geological Survey, Information Services \\ Box 25286, Denver Federal Center \\ Denver, CO 80225 \\ For more information about the USGS and its products: \\ Telephone: 1-888-ASK-USGS \\ World Wide Web: http://www.usgs.gov/
}

\footnotetext{
Any use of trade, product, or firm names in this publication is for descriptive purposes only and does not imply endorsement by the U.S. Government.

Although this report is in the public domain, permission must be secured from the individual copyright owners to reproduce any copyrighted materials contained within this report.
} 


\section{Contents}

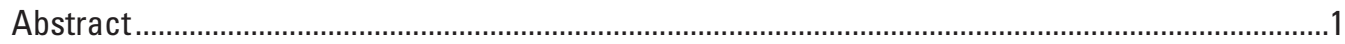

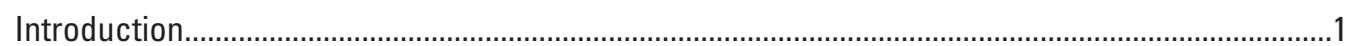

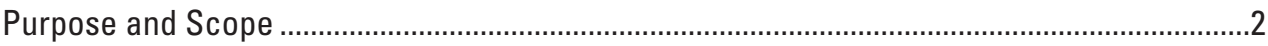

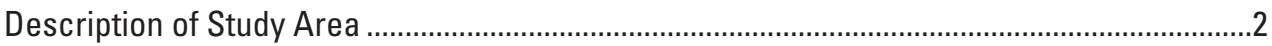

Previous Investigations.................................................................................................

Methods of Study

Continuous-Record Streamflow-Gaging Stations ...............................................................

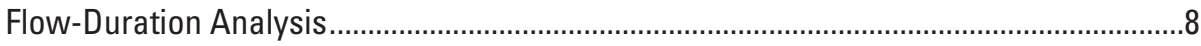

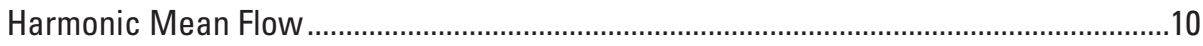

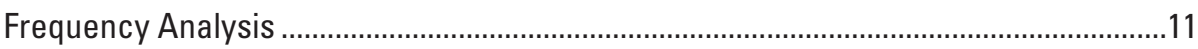

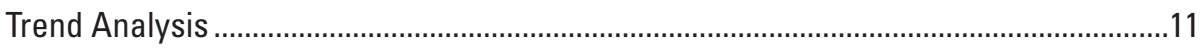

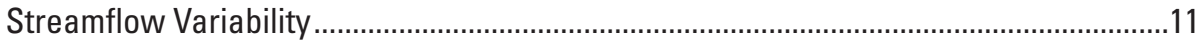

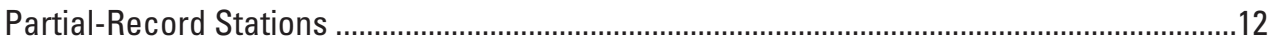

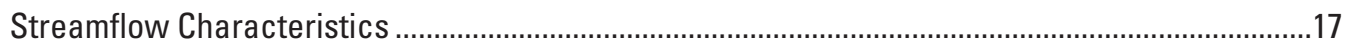

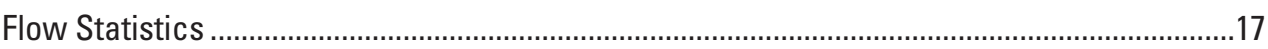

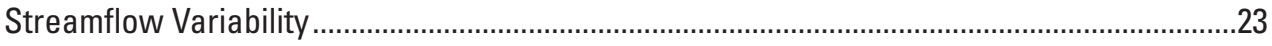

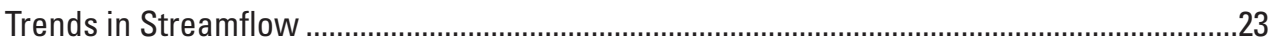

Comparison of Trends in Precipitation to Trends in Flow at Undeveloped Sites ............................29

Trends in Peak Ratio at Selected Streamflow-Gaging Stations....................................................32

Estimates of Low-Flow Statistics at Ungaged Sites ..................................................................

Ungaged Sites on Streams with Streamflow Data and No Regulation ...................................35

Ungaged Sites on Streams with Streamflow Data and Regulation.......................................35

Ungaged Sites on Streams with No Streamflow Data and No Regulation ..............................39

Ungaged Sites Downstream from a Permitted Point Source .....................................................39

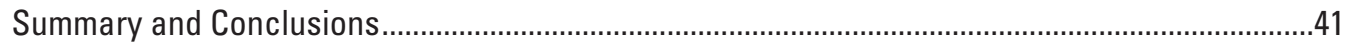

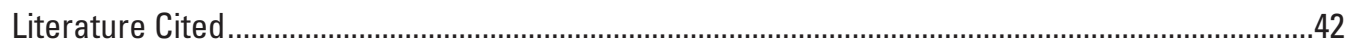

Appendix 1. Indexes of selected continuous-record streamflow-gaging stations, low-flow partial-record stations, and gaging stations analyzed as partial-record stations in

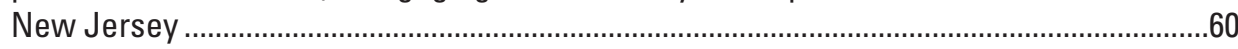

Appendix 2. Locations of streamflow-gaging stations by Watershed Management Areas ..........98

Appendix 3 . Results of trend tests on annual $n$-day low and high flow at 138 gaging stations

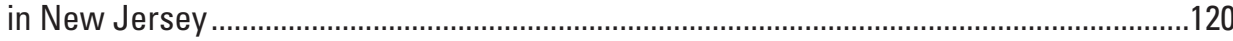

\section{Figures}

1-5. Maps showing-

1. Locations of selected continuous-record streamflow-gaging stations, low-flow partial-record stations, and streams within Climate Division 1, in New Jersey..........3

2. Locations of selected continuous-record streamflow-gaging stations, low-flow partial-record stations, and streams within Climate Division 2, in New Jersey.........4 
3. Locations of continuous-record streamflow-gaging stations, low-flow partialrecord stations, Watershed Management Areas, and water regions in New Jersey and vicinity

4. Physiographic provinces, climate divisions, and locations of National Weather Service rain gages in New Jersey.....

5. Locations of continuous-record streamflow-gaging stations with land use in New Jersey, 1995-97

6-7. Graphs showing-

6. Flow-duration curves for South Branch Raritan River at High Bridge, N.J., (01396500), and Great Egg Harbor River at Folsom, N.J. (01411000)

7. Low-flow frequency curves for South Branch Raritan River at High Bridge, N.J. (01396500)

8-12. Examples of-

8. Results generated by the MOVE1 correlation program listing statistics at an index site and the estimated statistics at a partial-record station in New Jersey .

9. Plots generated by the Maintenance of Variance Extension Type 1 (MOVE1) correlation analysis program to evaluate the relation between base-flow measurements at a low-flow partial-record station and daily mean flow at an index site in New Jersey.

10. Summary statistics estimated by use of the Maintenance of Variance Extension Type 1 (MOVE1) correlation program for South Branch Raritan River at Middle Valley, N.J (site 01396280), and the weighted mean of the estimates based on the standard error of estimation.

11. Summary statistics for continuous-record streamflow-gaging stations in New Jersey with 20 or more years of continuous streamflow record. .18

12. Summary statistics for low-flow partial-record stations in New Jersey

13-17. Graphs showing-

13. Relation of harmonic mean flow to 75 -percent flow duration for 158 periods of record at 138 gaging stations with greater than 10 years of record on selected streams in New Jersey.....

14. Kendal Tau trend lines for 1-day high and 7-day low flows at continuous-record streamflow-gaging stations on Flat Brook near Flatbrookville, N.J. (01440000), and Rockaway River above the Reservoir at Boonton, N.J. (01380500).

15. Total annual precipitation for New Jersey Climatic Divisions 1 and 2, water years 1895-2001.

16. Annual 7-day low flow from water year 1919 through 2001 with a 10-year moving average line for the continuous-record streamflow-gaging station South Branch Raritan River near High Bridge, N.J. (01396500).

17. Results from Kendall Tau trend analysis of annual precipitation in New Jersey

(a) Climatic Divisions 1 and (b) 2 and from rain gages at (c) Boonton and

(d) Wertsville, New Jersey.

18-22. Maps showing-

18. Results of peak-ratio trend analysis, by physiographic province, in New Jersey...

19. Location of continuous-record streamflow-gaging stations and low-flow partial-record stations in the North and South Branch Raritan Watershed Management Area (WMA) in New Jersey. 
20. Location of lakes, reservoirs, and selected streamflow-gaging stations upstream from the Hackensack River in New Jersey and vicinity.

21. Locations of continuous-record streamflow-gaging stations, low-flow partialrecord stations, and an ungaged site in the Hackensack and Pascack and the Lower Passaic and Saddle Watershed Management Areas, New Jersey.....

22. Locations of an ungaged site on an unnamed tributary to Lake lliff and continuous-record streamflow-gaging stations and low-flow partial-record stations in the Upper Delaware and Wallkill Watershed Management Areas in New Jersey.

\section{Tables}

1. Watershed Management Areas in New Jersey ................................................................5

2. Streamflow-gaging stations on unregulated streams that drain undeveloped basins in New Jersey.

3. Results of trend tests on the lowest annual $n$-day flow for the climatic year ending March 31 and the winter period from November through April at 138 streamflow-gaging stations in New Jersey.

4. Results of trend tests on the highest annual $n$-day flow for the water year ending September 30 and the winter period from November through April at 138 streamflow-gaging stations in New Jersey

5a. Results of trend tests on records of highest and lowest annual $n$-day flow for streamflow-gaging stations in New Jersey.

5b. Significant results of trend tests on records of highest and lowest annual $n$-day flow for streamflow-gaging stations in New Jersey.

6. Results from Kendall Tau trend analysis for total annual precipitation at selected sites in New Jersey

7. Results of analysis for trends in peak ratios at selected streamflow-gaging stations in New Jersey.

\section{Conversion Factors and Datum}

\section{Inch/Pound to SI}

\begin{tabular}{|c|c|c|}
\hline Multiply & By & To obtain \\
\hline \multicolumn{3}{|c|}{ Length } \\
\hline inch (in.) & 2.54 & centimeter $(\mathrm{cm})$ \\
\hline inch (in.) & 25.4 & millimeter (mm) \\
\hline \multicolumn{3}{|c|}{ Area } \\
\hline square mile $\left(\mathrm{mi}^{2}\right)$ & 259.0 & hectare (ha) \\
\hline square mile $\left(\mathrm{mi}^{2}\right)$ & 2.590 & square kilometer $\left(\mathrm{km}^{2}\right)$ \\
\hline \multicolumn{3}{|c|}{ Flow rate } \\
\hline cubic foot per second $\left(\mathrm{ft}^{3} / \mathrm{s}\right)$ & 0.02832 & cubic meter per second $\left(\mathrm{m}^{3} / \mathrm{s}\right)$ \\
\hline
\end{tabular}

Horizontal coordinate information is referenced to the North American Datum of 1983 (NAD 83). 


\title{
Streamflow Characteristics and Trends in New Jersey, Water Years 1897-2003
}

\author{
By Kara M. Watson, Robert G. Reiser, Steven P. Nieswand, and Robert D. Schopp
}

\section{Abstract}

Streamflow statistics were computed for 111 continuousrecord streamflow-gaging stations with 20 or more years of continuous record and for 500 low-flow partial-record stations, including 66 gaging stations with less than 20 years of continuous record. Daily mean streamflow data from water year 1897 through water year 2001 were used for the computations at the gaging stations. (The water year is the 12-month period, October 1 through September 30, designated by the calendar year in which it ends). The characteristics presented for the long-term continuous-record stations are daily streamflow, harmonic mean flow, flow frequency, daily flow durations, trend analysis, and streamflow variability.

Low-flow statistics for gaging stations with less than 20 years of record and for partial-record stations were estimated by correlating base-flow measurements with daily mean flows at long-term (more than 20 years) continuous-record stations. Instantaneous streamflow measurements through water year 2003 were used to estimate low-flow statistics at the partial-record stations. The characteristics presented for partial-record stations are mean annual flow; harmonic mean flow; and annual and winter low-flow frequency.

The annual 1-, 7-, and 30-day low- and high-flow data sets were tested for trends. The results of trend tests for high flows indicate relations between upward trends for high flows and stream regulation, and high flows and development in the basin. The relation between development and low-flow trends does not appear to be as strong as for development and highflow trends.

Monthly, seasonal, and annual precipitation data for selected long-term meteorological stations also were tested for trends to analyze the effects of climate. A significant upward trend in precipitation in northern New Jersey, Climate Division 1 was identified. For Climate Division 2, no general increase in average precipitation was observed. Trend test results indicate that high flows at undeveloped, unregulated sites have not been affected by the increase in average precipitation.

The ratio of instantaneous peak flow to 3-day mean flow, ratios of flow duration, ratios of high-flow/low-flow frequency, and coefficient of variation were used to define streamflow variability. Streamflow variability was significantly greater among the group of gaging stations located outside the Coastal Plain than among the group of gaging stations located in the Coastal Plain.

\section{Introduction}

Streamflow measurements and statistics are needed by water managers and planners. The magnitude and frequency of low and high streamflows in New Jersey are used for watershed management and planning purposes. High-flow statistics are used by engineers to design bridges, dams, and flood-control structures. Low-flow statistics are used by water-supply planners and regulatory agencies for reservoir design and for permitting purposes. Minimum passing flows and reservoir safe yields are concerns for water suppliers across New Jersey. The New Jersey Department of Environmental Protection (NJDEP) uses low-flow statistics for allocating surface-water withdrawals and for setting waste-load allocation limits for municipal and industrial facilities that discharge effluent to surface water. The statistics also are a critical part of studies of total maximum daily loads ${ }^{1}$ (TMDLs) and studies of the effects of point and nonpoint sources of contamination on the chemical and biological qualities of streams.

The U.S. Geological Survey (USGS), in cooperation with other Federal, State, and local agencies, has collected daily mean streamflow data in New Jersey since 1897 (Gillespie and Schopp, 1982). Daily mean flows currently (2005) are recorded at 92 continuous-record streamflow-gaging stations $^{2}$ and previously were recorded at an additional 104 gaging stations (Reed and others, 2003). Daily mean flows are used to compute streamflow statistics such as flow duration, and high-flow and low-flow frequency. They are used to describe the volume of water flowing past a site and the frequency of occurrence of flows of a given magnitude. The last published report of low-flow and flow-duration statistics for New Jersey streams included data through the 1975 water year $^{3}$ (Gillespie and Schopp, 1982). Since the 1975 water

\footnotetext{
${ }^{1}$ Words in bold are defined in the Glossary at the end of the report.

${ }^{2}$ Referred to as gaging station in this report.

${ }^{3}$ Water year is the 12-month period, October 1 through September 30, designated by the calendar year in which it ends.
} 
year, an additional 26 years of data has been collected at many gaging stations. Twenty or more years of data have been collected at some new gaging stations that did not have any data available for analysis in the last study (Gillespie and Schopp, 1982). Streamflow-gaging stations, streams, and climate divisions referenced in this report are shown in figures 1 and 2.

The USGS, in cooperation with the NJDEP, has analyzed the continuous records of streamflow through the 2001 water year and the low-flow instantaneous measurements of streamflow at low-flow partial-record stations ${ }^{4}$ through the 2003 water year to update low-flow statistics and flow-duration statistics and to compute other streamflow statistics for New Jersey streams. The additional data will provide more accurate long-term statistics for water managers. The statistics provided in this report, but not in previous reports, such as low-flow frequency for the winter season and harmonic mean flow, have been used by water managers in recent years for regulatory purposes. Statistics on high-flow frequencies for winter and annual periods, streamflow variability, and trend analysis also are provided in this report to assist those studying surfacewater hydrology and hydraulics in New Jersey.

\section{Purpose and Scope}

The purpose of this report is to update and expand the previous information on flow characteristics and flow duration of New Jersey streams provided by Gillespie and Schopp (1982). This report provides a source of updated streamflow statistics for water-resource managers and planners. Streamflow characteristics are presented for 111 gaging stations with 20 or more years of record and 500 partial-record stations, including 42 gaging stations with less than 10 years of record and 24 gaging stations with 10 to 19 years of record, which were analyzed as partial-record stations. This report presents streamflow statistics for stations in New Jersey and a few stations in Pennsylvania and New York on major streams that could have an effect on New Jersey streams. Appendixes include an inventory of all gaging stations and partial-record stations analyzed in this study; maps of all continuous-record streamflow-gaging stations and low-flow partial-record stations in this report, by Watershed Management Area; and high and low-flow trend results.

\section{Description of Study Area}

New Jersey is divided into five water regions-the Passaic, Raritan, Upper Delaware, Lower Delaware, and Atlantic Coastal water regions. These regions are divided into 20 Watershed Management Areas (table 1), which are subdivided into more than 100 individual watersheds. These management areas were established by NJDEP to manage and protect the freshwater resources in New Jersey (Watt, 2000). The Raritan River Basin (Watershed Management Areas 7, 8, 9, and 10) comprises an area of $1,105 \mathrm{mi}^{2}$ in central and northern New

\footnotetext{
${ }^{4}$ Referred to as partial-record stations in this report.
}

Jersey. It is the largest drainage basin entirely within the State of New Jersey (fig. 3).

New Jersey river basins drain areas spanning four physiographic provinces (fig. 4). The Piedmont, New England, and Valley and Ridge Provinces lie in northern New Jersey above the Fall line (fig. 4). The Coastal Plain Province encompasses southern New Jersey below the Fall line. The Valley and Ridge Province covers the northwestern part of the State in the Delaware River Basin and the Wallkill River Basin. The area is underlain by faulted and folded sedimentary layers of sandstone, shale, and limestone. Alternating belts of erosionresistant sandstone and less-resistant eroded shale and limestone create the long, parallel, northeast-southwest-trending ridges and valleys that are characteristic of the province. The New England Province is underlain predominately by granite, gneiss, and small amounts of marble of Precambrian age. These rocks are resistant to erosion and create a hilly upland dissected by the deep steep-sided valleys of major streams. The Piedmont Physiographic Province is a broad lowland that contains ridges underlain by interbedded sandstone, shale, conglomerate, basalt, and diabase. The Coastal Plain is mainly flat and is underlain by unconsolidated layers of sand, silt, and clay (New Jersey Department of Environmental Protection and Energy, 1992).

Land-use information was derived for each of the drainage basins associated with the gaging stations studied. The land uses for gaging stations with drainage areas entirely in New Jersey were derived from a geographic information system (GIS) coverage developed from 1995/97 digital infrared aerial photos (N.J. Department of Environmental Protection, 2000) through use of the Anderson method of classification (Anderson and others, 1976). For these gaging stations, a 30-meter-grid digital elevation model (DEM) coverage of New Jersey and coordinates of the site location were used to create a basin boundary for each site. The 1995/97 land-use coverage was overlaid on the basin polygon. The size of the basin and the size of each land-use area within the basin were used to compute the land-use percentages. Land-use information for the Delaware, Neversink, Lehigh, and Schuykill River gaging stations is from 1992 Multi-Resolution Land Characteristics/National Land Cover Data (MRLC/NLCD) produced by a Federal consortium at the Earth Resource Observation Systems (EROS) data center. The base data set was Landsat Thematic Mapper data, nominal-1992 acquisitions (Jeffrey Fischer, U.S. Geological Survey, written commun., 2003). Land use was characterized as developed or undeveloped on the basis of the percentages of urban, agricultural, forested, wetland, open water, and barren land in each basin. The urban land-use category is a composite of residential, commercial, and industrial uses. Developed land is defined as the sum of urban and agricultural land uses. Undeveloped land is defined as the sum of forested, wetland, open water, and barren land areas. For this study, 14 gaging stations with drainage basins in which 86 to 100 percent of the area is undeveloped were categorized as undeveloped (table 2). 

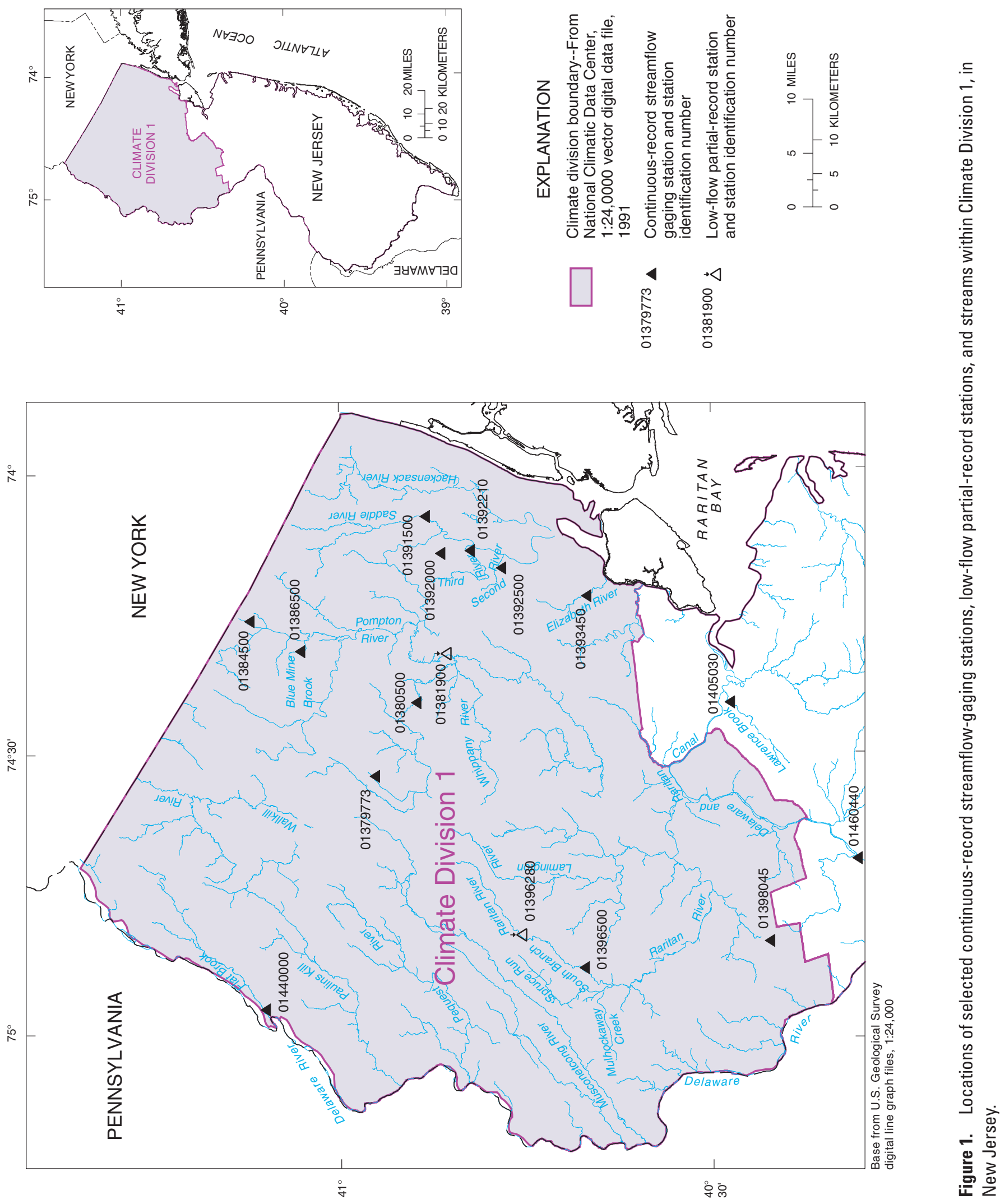

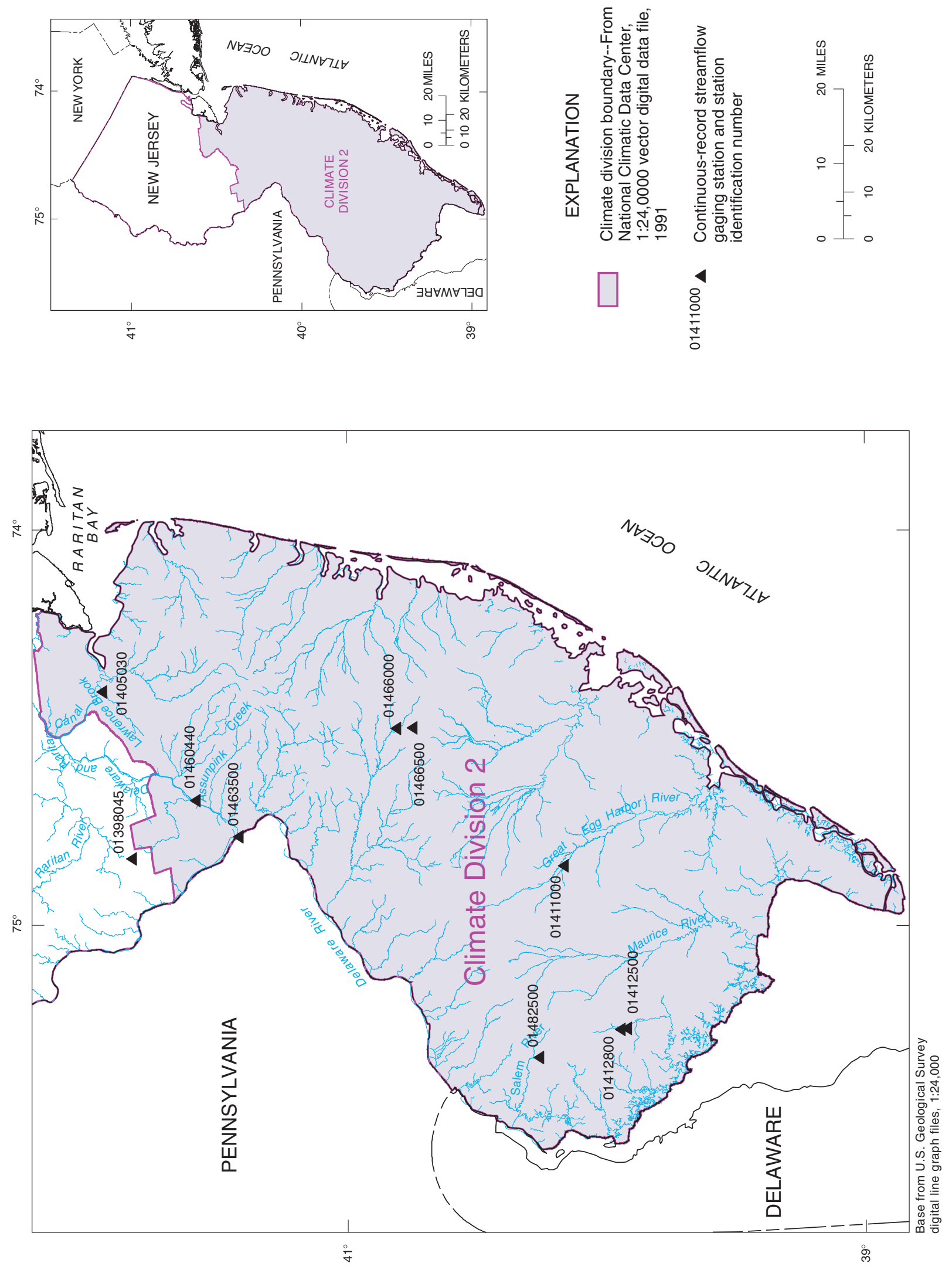

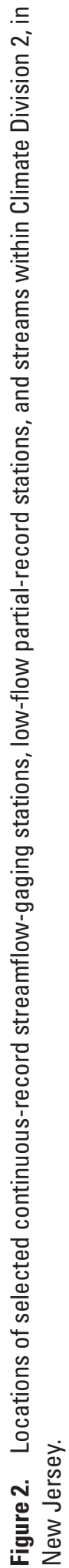


The land uses in the drainage basins upstream from the gaging stations studied range from 100-percent undeveloped to 93-percent developed. Gaging stations on McDonalds Branch in Lebanon State Forest (01466500) and Middle Branch Mount Misery Brook in Lebanon State Forest (01466000) (fig. 5) are in areas that are 100-percent undeveloped. These two gaging stations are in the Pinelands area of southern New Jersey. A total of seven gaging stations in the Pinelands area of southern New Jersey, three gaging stations in northwestern New Jersey, and one gaging station on the east coast of New Jersey drain areas that are more than 90 percent undeveloped. More than 90-percent of the land use upstream from Second River at Belleville (01392500), Elizabeth River at Ursino Lake at Elizabeth (01393450), Third River at Passaic (01392210), and Weasel Brook at Clifton (01392000) (fig. 5) is urban. More than 70 percent of the land use upstream from West Branch Cohansey River at Seeley (01412500), Cohansey River at Seeley (01412800), and Salem River at Woodstown (01482500) (fig. 5) is agricultural.

\section{Previous Investigations}

The USGS began a statewide program of base-flow monitoring in 1958, in cooperation with the New Jersey Department of Conservation and Economic Development, Division of Water Policy and Supply. The purpose of the program was to determine minimum daily flow for streams in the State as required by a surface-water diversion law. Minimum daily flows at partial-record stations were estimated by graphically correlating base-flow measurements to daily mean flows at gaging stations. A report by Buchanan and others (1965) documents minimum daily flows at gaging stations and locations of partial-record stations and gives an example of the graphical correlation technique.

The monitoring program has been continued through the years as a cooperative project with NJDEP to collect base-flow data at locations with little or no streamflow data. Gillespie and Schopp (1982) computed 7-day 2-year low flow (7Q2), 7-day 10-year low flow (7Q10), and flow durations for 105 gaging stations in New Jersey and neighboring States. A regression method was used to calculate $7 \mathrm{Q} 2$ and $7 \mathrm{Q} 10$ for 417 low-flow partial-record stations and gaging stations in New Jersey with less than 7 years of record. The statistics were computed from flow data for gaging stations through water year 1975 .

\section{Methods of Study}

Streamflow characteristics were analyzed for long-term gaging stations, partial-record stations, and gaging stations with less then 20 years of record analyzed as partial-record stations. The characteristics studied for gaging stations are daily streamflow, harmonic mean flow, flow frequency, daily flow durations, trend analysis, and streamflow variability.
Table 1. Watershed Management Areas in New Jersey.

[See figure 1 for New Jersey Department of Environmental Protection Watershed Management Areas]

\begin{tabular}{|c|c|c|}
\hline \multirow{2}{*}{ Number } & Watershed Management Area & \multirow{2}{*}{ Water region } \\
\hline & Name & \\
\hline 01 & Upper Delaware & Upper Delaware \\
\hline 02 & Wallkill & Upper Delaware \\
\hline 03 & $\begin{array}{l}\text { Pompton, Pequannock, Wanaque, } \\
\text { Ramapo }\end{array}$ & Passaic \\
\hline 04 & Lower Passaic, Saddle & Passaic \\
\hline 05 & Hackensack, Hudson, Pascack & Passaic \\
\hline 06 & $\begin{array}{l}\text { Upper and Mid Passaic, Whippany, } \\
\text { Rockaway }\end{array}$ & Passaic \\
\hline 07 & Arthur Kill & Raritan \\
\hline 08 & North and South Branch Raritan & Raritan \\
\hline 09 & Lower Raritan, South River, Lawrence & Raritan \\
\hline 10 & Millstone & Raritan \\
\hline 11 & Central Delaware & Upper Delaware \\
\hline 12 & Monmouth & Atlantic Coastal \\
\hline 13 & Barnegat Bay & Atlantic Coastal \\
\hline 14 & Mullica & Atlantic Coastal \\
\hline 15 & Great Egg Harbor & Atlantic Coastal \\
\hline 16 & Cape May & Atlantic Coastal \\
\hline 17 & Maurice, Salem, Cohansey & Lower Delaware \\
\hline 18 & Lower Delaware & Lower Delaware \\
\hline 19 & Rancocas & Lower Delaware \\
\hline 20 & Assiscunk, Crosswicks, Doctors & Lower Delaware \\
\hline
\end{tabular}

Characteristics studied for partial-record stations are mean annual flow, harmonic mean flow, and annual and winter lowflow frequency.

\section{Continuous-Record Streamflow-Gaging Stations}

Low-flow and high-flow statistics were computed from continuous records of streamflow collected at 111 gaging stations across New Jersey that have 20 or more years of record. Streamflow-gaging stations provide flow data at regular intervals throughout the day. The data, usually collected at 15-minute intervals, are used to compute daily mean-flow values. A series of data sets representing the lowest mean discharge for each year for a specified number of consecutive days are generated for each gaging station. A Log Pearson Type III frequency distribution typically is used to compute low-flow statistics for gaging stations. 


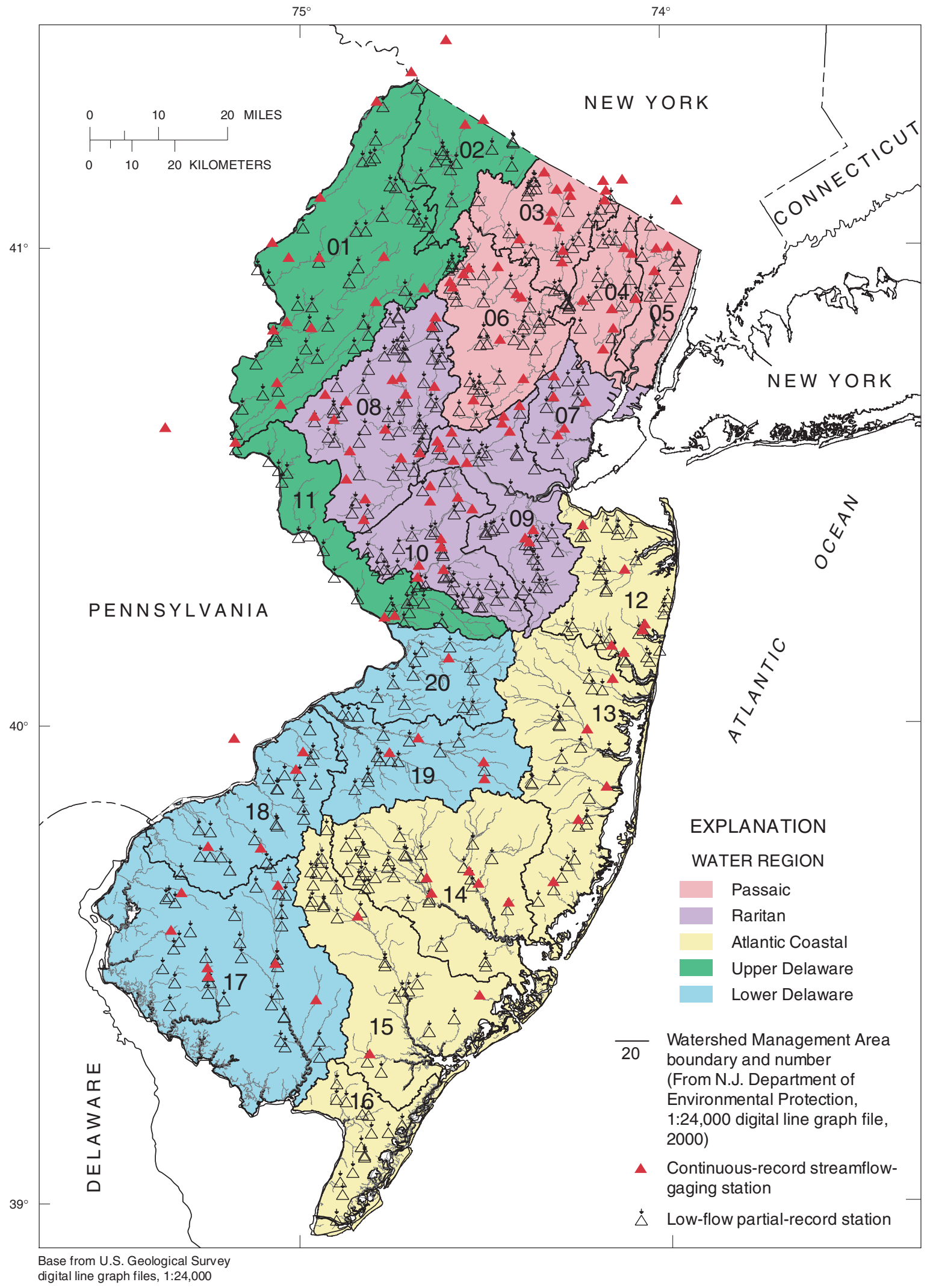

Figure 3. Locations of continuous-record streamflow-gaging stations, low-flow partial-record stations, Watershed Management Areas, and water regions in New Jersey and vicinity. (Watershed Management Area names are listed in table 1.) 


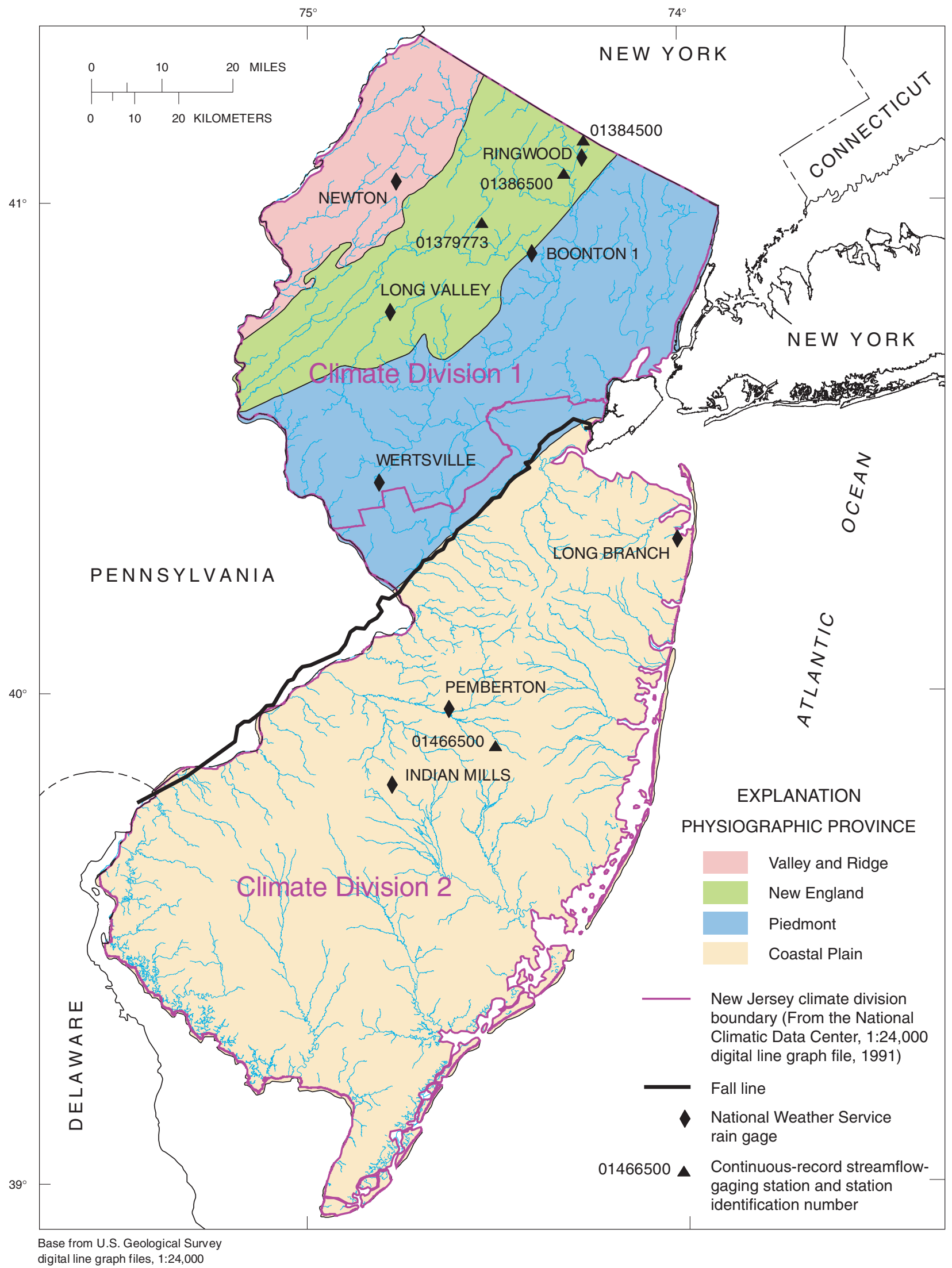

Figure 4. Physiographic provinces, climate divisions, and locations of National Weather Service rain gages in New Jersey. 
Table 2. Streamflow-gaging stations on unregulated streams that drain undeveloped basins in New Jersey.

[Undeveloped basins contain less than 15-percent developed land; \%, percent; ID, identification; see figure 5 for gaging station locations with land use]

\begin{tabular}{|c|c|c|c|c|c|}
\hline Station ID & Station name & $\begin{array}{c}\text { Urban } \\
(\%)\end{array}$ & $\begin{array}{c}\text { Agriculture } \\
(\%)\end{array}$ & $\begin{array}{c}\text { Total developed } \\
(\%)\end{array}$ & $\begin{array}{l}\text { Climate } \\
\text { division }\end{array}$ \\
\hline 01384500 & Ringwood Creek near Wanaque, N.J. & 14.03 & 0.00 & 14.03 & 1 \\
\hline 01409400 & Mullica River near Batsto, N.J. & 6.31 & 5.99 & 12.30 & 2 \\
\hline 01379773 & Green Pond Brook at Picatinny Arsenal, N.J. & 11.53 & .31 & 11.83 & 1 \\
\hline 01411300 & Tuckahoe River at Head of River, N.J. & 3.96 & 7.75 & 11.71 & 2 \\
\hline 01440000 & Flat Brook near Flatbrookville, N.J. & 3.03 & 5.34 & 8.37 & 1 \\
\hline 01409810 & West Branch Wading River near Jenkins, N.J. & .84 & 6.60 & 7.44 & 2 \\
\hline 01409000 & Cedar Creek at Lanoka Harbor, N.J. & 5.41 & .52 & 5.93 & 2 \\
\hline 01386500 & Blue Mine Brook near Wanaque, N.J. & 5.01 & .46 & 5.47 & 1 \\
\hline 01409095 & Oyster Creek near Brookville, N.J. & 2.66 & .65 & 3.31 & 2 \\
\hline 01410000 & Oswego River at Harrisville, N.J. & .93 & 1.85 & 2.78 & 2 \\
\hline 01410150 & East Branch Bass River near New Gretna, N.J. & 2.00 & .00 & 2.00 & 2 \\
\hline 01409280 & Westecunk Creek at Stafford Forge, N.J. & .80 & .50 & 1.30 & 2 \\
\hline 01466000 & MB Mt Misery Bk in Lebanon State Forest, N.J. & .00 & .00 & .00 & 2 \\
\hline 01466500 & McDonalds Branch in Lebanon State Forest, N.J. & .00 & .00 & .00 & 2 \\
\hline
\end{tabular}

A low-flow frequency curve is computed for each series of measurements as described in Riggs (1972). The statistics computed at the gaging stations are used as a basis for estimating low-flow statistics at ungaged sites and at the 66 gaging stations with less than 20 years of record.

Two exceptions were made to the guideline established for categorizing gaging stations with 20 or more years of record as continuous-record stations. The gaging station on Lawrence Brook at Westons Mills, N.J. (01405030) (fig. 1), has less than 20 years of continuous record. For this study, statistics were computed using the continuous-gage record because the flow passing the gaging station is regulated and statistically significant correlations with other long-term gaging stations do not exist. The other exception is the gaging station at Passaic River at Pine Brook, N.J. (01381900)

(fig. 1), with 22 years of continuous record. This gaging station is considered to be a partial-record station for this study because of its proximity to other gaging stations upstream and downstream from the site with more than 70 years of record.

\section{Flow-Duration Analysis}

A flow-duration curve is a cumulative frequency curve that shows the percentage of time specified flows are equaled or exceeded for a given period of time (Searcy, 1959). Flowduration curves were computed for each gaging station from daily mean flows for the entire period of record. Daily mean flows for the entire period of record were arranged in order of magnitude and divided into 35 classes. A curve was drawn through the average discharge for each class in relation to the percentage of time that flow was equaled or exceeded. The flow-duration curve shows the daily mean flow that was exceeded for the indicated percentage of time.

The flow-duration curve is useful for analyzing the availability and variability of streamflow. The flow-duration curve, when based on many years of record, indicates the probable future behavior of a stream, assuming the basin will not be substantially altered by man's activities (Searcy, 1959). The shape of the flow-duration curve is indicative of hydrologic conditions in the drainage basin. A curve with a steep slope is indicative of a basin with highly variable flow with most of the streamflow coming from direct runoff. A gaging station on a stream that drains an area with steep topography and shallow soils will have a flow-duration curve with a steep slope. A flat flow-duration curve is typical of a stream that drains an area with flat topography and a high percentage of land area classified as wetlands. An appreciable part of streamflow at these gaging stations is contributed by ground water.

The flow-duration curves at two gaging stations with similar drainage areas are shown in figure 6. The Great Egg Harbor River (fig. 2) drains an area that is representative of flat topography in the Coastal Plain Physiographic Province of southern New Jersey. The South Branch Raritan River (fig. 1) drains an area of steeper topography in the New England Physiographic Province. The flow-duration curve for the South Branch Raritan River gaging station (01396500) has 


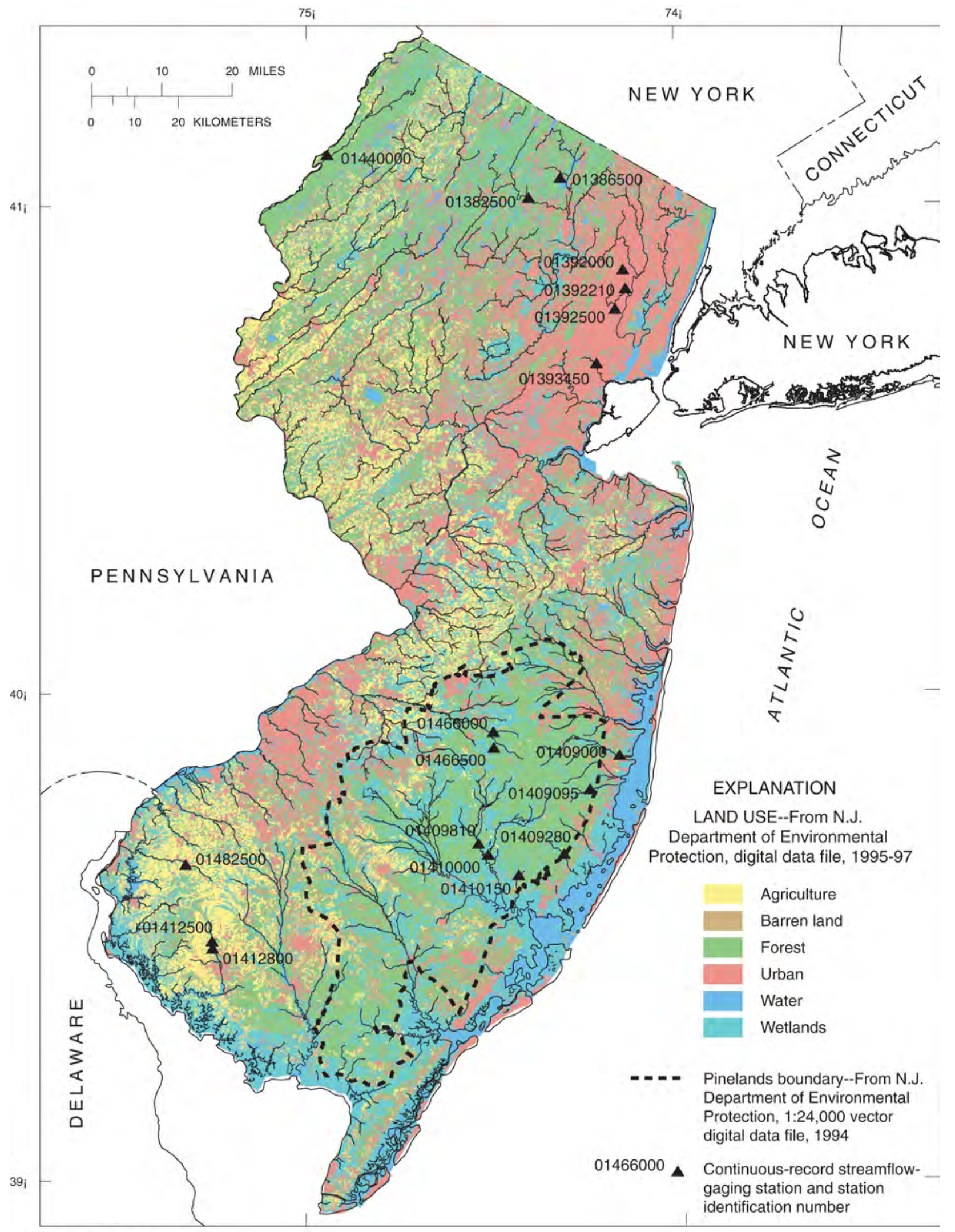

Base from U.S. Geological Survey

digital line graph files, 1:24,000

Figure 5. Locations of continuous-record streamflow-gaging stations with land use in New Jersey, 1995-97. 


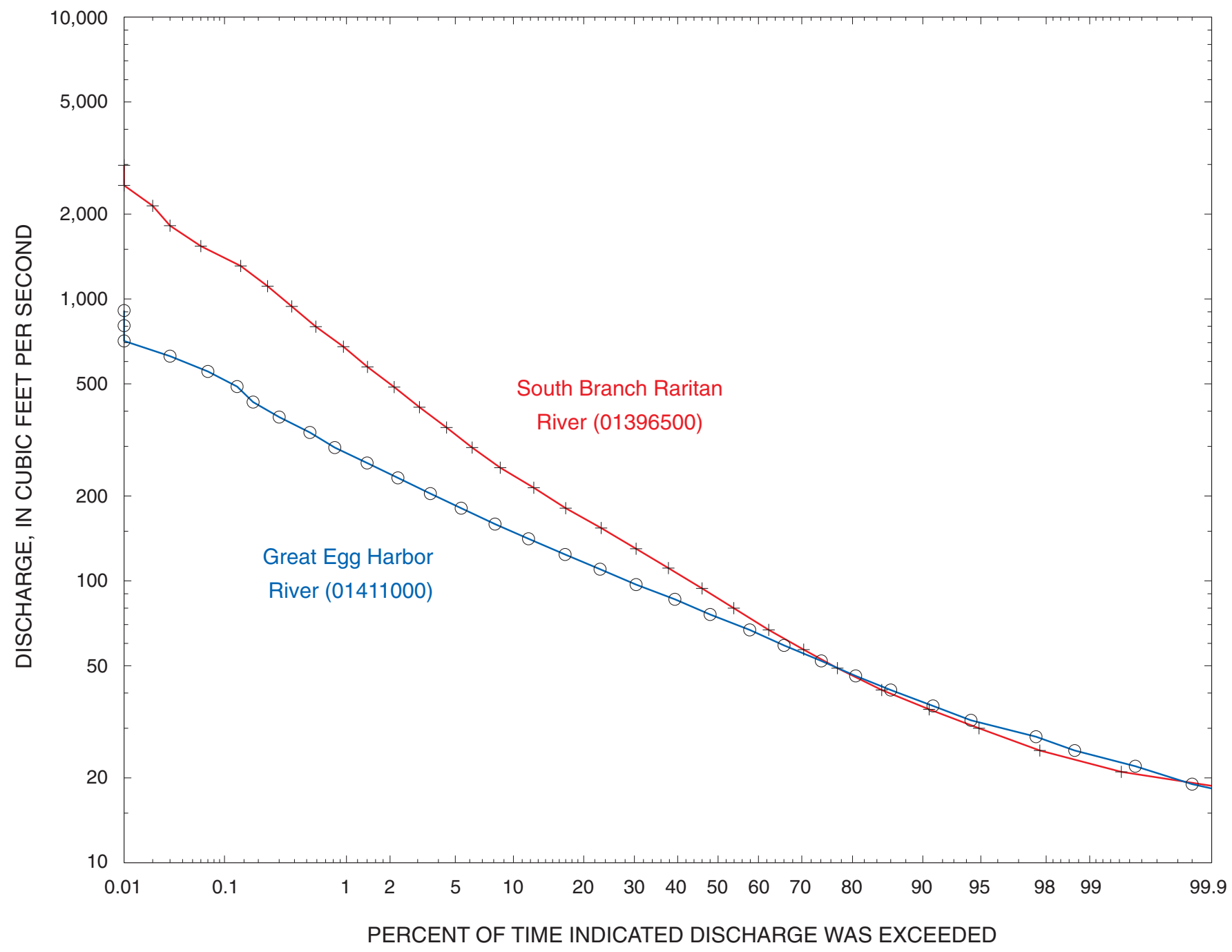

Figure 6. Flow-duration curves for South Branch Raritan River at High Bridge, N.J., (01396500), and Great Egg Harbor River at Folsom, N.J. (01411000).

a steeper slope than the flow-duration curve for the Great Egg Harbor River gaging station (01411000). The flow per square mile at 1-percent flow duration at gaging station 01396500 is twice as high as at gaging station 01411000. Flows greater than 70-percent flow duration are higher and flows less than 80-percent flow duration are lower at gaging station 01396500 than at gaging station 01411000 .

\section{Harmonic Mean Flow}

Harmonic mean flow is a statistic used as a design flow applied to water-quality criteria for the protection of human health under lifetime exposure to toxic contaminants (Rossman, 1990). The harmonic mean flow is defined as the reciprocal of the mean of the reciprocal of the daily flows or

$$
Q_{H M}=\frac{N}{1 / Q_{1}+1 / Q_{2}+\ldots+1 / Q_{N}} \text {, }
$$

where

$$
\begin{aligned}
Q_{H M} & =\text { harmonic mean flow }, \\
N & =\text { number of days },
\end{aligned}
$$

and

$$
Q_{1} \quad=\text { streamflow on day } 1 .
$$

The formula for harmonic mean flow cannot be used directly when daily mean flows of zero are present in the data set. To adjust for zero flows, the harmonic mean of the nonzero daily mean streamflows was multiplied by the ratio of 
the number of nonzero daily mean flows to the total number of daily mean flows in the period of record analyzed (Martin and Ruhl, 1993). The proportional adjustment for zero flows is consistent with current U.S. Environmental Protection Agency design flow methodology (Rossman, 1990). Harmonic mean flow is always lower or equal to the arithmetic mean flow because harmonic mean gives greater weight to the lowest daily mean flows.

\section{Frequency Analysis}

A frequency curve relates the magnitude of a variable to frequency of occurrence (Riggs, 1968). Daily streamflow data were analyzed to determine the frequency of occurrence of low-flow and high-flow events. Frequency curves of low- and high-flow events were developed for both annual and winter periods (November-April). The magnitude of low- and highflow events is inversely related to the frequency of occurrence. The recurrence interval is the average length of time between exceedances or non-exceedances of a particular magnitude (Riggs, 1968).

The minimum average flow for a given period of days is used to develop a low-flow frequency curve, and the maximum average flow is used to develop a high-flow frequency curve. The period of days used is referred to as the $n$-day period. For this study, frequency statistics were computed for the minimum and maximum average 1-day, 7-day, and 30-day flows for each year or season of each year for the period of record. When analyzing low flow, the probability that a streamflow is not exceeded for a given period of time (annual or winter season) is referred to as the non-exceedance probability. The probability that streamflow is exceeded for a given period of time is referred to as the exceedance probability.

A $\log$ Pearson Type III frequency distribution was used for this study because it usually fits the distribution of streamflows well. The log Pearson Type III frequency curves were examined for each gaging station using the USGS program SWSTAT (Flynn, and others, 1995). The log Pearson Type III distribution can be represented by the equation (Telis, 1991)

$$
\log \left(Q_{t}\right)=X+K_{t} S
$$

where

$$
\begin{aligned}
Q_{t}= & n \text {-day flow, } \\
t= & \text { recurrence interval in years, } \\
X \quad= & \text { mean of the base } 10 \text { logarithms of the } \\
& \text { annual or seasonal } n \text {-day flows, } \\
K_{t \quad=} & \text { frequency factor that is a function of the } \\
& \text { recurrence interval and the coefficient of } \\
& \text { skew, }
\end{aligned}
$$

and

$S \quad=$ standard deviation of the logarithms of the annual or seasonal $n$-day flows.
A frequency curve was hand drawn on log probability paper when the SWSTAT method for log Pearson Type III curve did not fit the data. The program did not generate frequency curves for various data sets at seven gaging stations because of large skews in the data, mainly as a result of regulation at low streamflow.

An example of low-flow frequency curves for South Branch Raritan River at High Bridge, New Jersey (01396500) is shown in figure 7. The plot shows the frequency distribution for 1-day, 3-day, 7-day, 30-day, and 90-day annual low flows. The curves are log Pearson Type III frequency distributions.

\section{Trend Analysis}

The time series of selected streamflow characteristics at each gaging station with more than 10 years of daily streamflow records were evaluated for trends using the Kendall's Tau test (Helsel and Hirsch, 2002). The same test was applied to annual and monthly precipitation data, annual coefficient of variation, and peak-flow ratios. This is a nonparametric test designed for data that are not normally distributed. Kendall's Tau was used to identify changes in the streamflow and precipitation data over time. The test determines the probability that the null hypothesis of no significant trend can be rejected with a low risk of error. A $p$-value equal to 0.05 indicates there is a 95-percent chance that a trend is present. For this study, a trend test on the annual and monthly data series with a $p$-value of less than or equal to 0.05 is considered a significant result. A negative Kendall Tau coefficient indicates a downward trend. A positive Tau value indicates an upward trend.

\section{Streamflow Variability}

The variability at a gaging station was measured using a few different statistics. The coefficient of variation, the ratio of instantaneous peak flow to 3-day mean flow surrounding the peak, the ratios of 25-percent/75-percent and 10-percent/ 90-percent flow durations, and the ratios of 1-day 2-year high flow/1-day 2-year low flow and 1-day 20-year high flow/ 1-day 20-year low flow were tested as measures of streamflow variability. The ratio statistics were computed for the entire period of record.

The Wilcoxon rank sum test was used to test for differences in the means of two data sets. It is the non-parametric equivalent to a $t$-test. The null hypothesis (HO) states that mean rank of the streamflow variability statistics are equal between two groups. A $p$-value of 0.05 was used to minimize the chance that the difference occurred by chance alone. Comparisons were made between gaging stations grouped by physiographic province and by land use.

The coefficient of variation was computed for the entire period of record at all gaging stations with 20 or more years of record and for each complete water year in the record. The coefficient of variation is the standard deviation divided by the mean of the data set (Ott, 1988). The coefficient of variation 


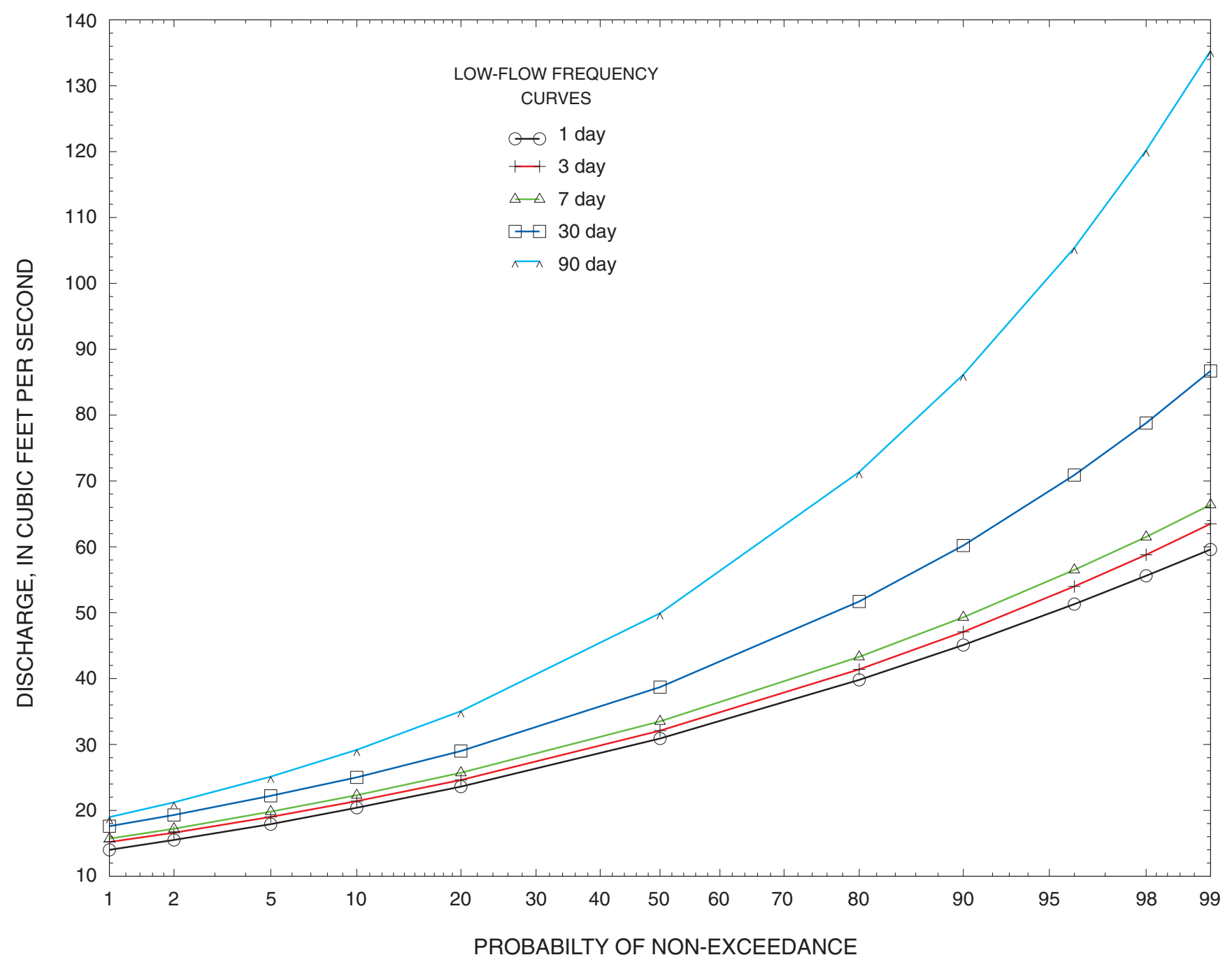

Figure 7. Low-flow frequency curves for South Branch Raritan River at High Bridge, N.J. (01396500).

allows for direct comparisons in variability of streamflow between gaging stations with differences in daily mean flows. The annual coefficient of variation was calculated for selected gaging stations and tested for trends.

The peak ratio is determined from annual peak flow, which is the maximum instantaneous streamflow value for the water year, divided by the 3-day mean flow for 3 consecutive days including the day before, day of, and day after the peak. Peak ratio is a measure of the magnitude of the rise and fall of a stream over a given period of time. Environmental factors can effect a change in the peak ratio at a gaging station for a given amount and duration of precipitation. Changes in the amount of impervious surfaces, vegetative cover in riparian areas, and land uses in a drainage area can cause changes in the capacity of a watershed to attenuate and store runoff, causing changes in the peak ratio over time. The peak ratio trend was determined for selected gaging stations using the Kendall's Tau test (Helsel and Hirsch, 2002). The test determines the probability that the null hypothesis of no significant trend can be rejected with a low risk of error. A $p$-value equal to 0.05 indicates there is a 95-percent chance that a trend is present. For this study, a trend test on the peak ratio with a $p$-value of less than or equal to 0.05 is considered a significant result.

\section{Partial-Record Stations}

Instantaneous streamflow measurements made at baseflow conditions are used to estimate low-flow statistics at gaging stations with less than 20 years of record and at sites on streams without any continuous record of streamflow. Base-flow measurements are made periodically at low-flow partial-record stations, water-quality sampling sites, creststage gaging stations, and miscellaneous sites established for special USGS studies. From 1959 through 2003, base-flow measurements were made at 500 low-flow partial-record 
stations. Currently (2005), base-flow conditions are measured 2 to 3 times a year at more than 40 low-flow sites. Typically, 10 to 12 base-flow measurements made over a 5- to 6-year period provide an adequate amount of data to establish a correlation between low-flow conditions at a continuousrecord gaging station and those at the low-flow station. Recently, base flow has been measured at sites that had been inactive for many years in order to investigate possible changes in base flow. During water year 2001, one or more measurements of base flow were made at 105 active and previously inactive low-flow stations.

Instantaneous base-flow measurements at partial-record stations were correlated to daily mean flow at gaging stations in basins with similar hydrologic conditions. The low-flow statistics were estimated by using the Maintenance of Variance Extension Type 1 (MOVE1) method of correlation analysis (Hirsch, 1982) when an adequate number of base-flow measurements were available. The MOVE1 method fits a straight line to a data set. MOVE1, also known as the organic line of correlation, was proposed as a linear fitting procedure in hydrology and is further explained by Helsel and Hirsch (2002). The flows are transformed to logarithms to make the distribution of data more symmetrical and the relation more linear. The correlation coefficient and standard error of estimate are used as measures of accuracy. Daily mean flows from at least three gaging stations, referred to as index sites in the MOVE1 program, are correlated with measurements at each partial-record station. A weighted mean of all the estimates is computed on the basis of the standard error of estimate.

Only measurements made at base-flow conditions are used in the MOVE1 analysis. Tests to evaluate base-flow conditions at the index site and changes in stage at the lowflow station are used to determine whether measurements were made at base-flow conditions. A base-flow test is applied to the daily mean flows at the index site. Data are defined as being base flow when the daily mean flow at the index site drops by less than 30 percent or rises by less than 10 percent from the previous day. A test of conditions during streamflow measurement is made to reject measurements with a change in stage during the measurement of greater than $0.02 \mathrm{ft}$, unless a tide or control structure adjustment was made to the measured flow.

An additional test is sometimes performed on the previous two days of daily flow at the index site before the measurement was made. This test is performed only when measurements in the database are flagged as being base flow. If the daily flows do not pass the base-flow test, an estimated daily base flow is used for the index site when the base-flow measurement is flagged as such. Linear extrapolation of the daily mean flow from the previous 2 days is used to estimate the daily mean flow on the day the measurement was made. This procedure allows the use of base-flow data that otherwise would be removed from the analysis. An example of the need for this procedure is when a measurement at a partial-record station is made at base-flow conditions in the morning and precipitation in the afternoon causes the stream at the index site to rise. Also, a test is available for base flow at streamflow-gaging stations with very low flows. The absolute value of the change in flow must be less than $0.2 \mathrm{ft}^{3} / \mathrm{s}$ from the previous day to the day in which the flow was measured to qualify as base flow. At very low flows, a change in stage of less than $0.01 \mathrm{ft}$ (the precision of the instrumentation) can change the flow by greater than 20 percent.

Estimated statistics for a partial-record station are computed on the basis of a weighted mean of results from MOVE1 correlations typically run with data from three or more index sites. If the estimates of flow statistics from these correlations vary widely, additional correlations with nearby gaging stations are run to obtain better estimates. Results from as few as one correlation could be used at a partial-record station located on the same stream in close proximity to a gaging station. In that case, correlations with other gaging stations in the vicinity would not considerably improve the estimate. The estimates from each correlation are weighted together inversely, on the basis of the standard error of estimate. Correlations with a lower standard error have a stronger effect on the estimate. This standard error of estimate is a function of the scatter of the data about the line, the number of measurements used to develop the line, how far the relation is extended from the measurements to predict statistics at the partial-record station, and the standard error of the index-gage statistics (Telis, 1991).

A table of the estimated statistics and plots of the data is generated for each MOVE1 correlation. Examples of the outputs from a correlation between an index site-South Branch Raritan River at High Bridge (01396500) (fig. 1) and a partial-record station - South Branch Raritan River at Middle Valley (01396280) (fig. 1)—are shown in figures 8 and 9 . The statistics estimated from each correlation and a weighted mean of all the estimates based on the standard error are summarized in a table, as shown in figure 10 , for each partial-record station.

The plots shown in figure 9 are used to assure the quality of the data and to look for trends in the relation between daily mean flows at the index site and instantaneous measurements of base flow at the low-flow sites. Outliers are identified by analyzing percent difference between actual and predicted values, as well as visual analysis of plots (fig. 9). When outliers are identified, the discharge measurement form on which the velocities, depths, and areas of measured flow were recorded is examined for mistakes. The flow on the measurement form is compared to the flow stored in the database, velocities on the form are compared with the rating table for the meter used, and measurement computations are checked. The residuals computed from the MOVE1 correlation program are defined as the difference between the predicted flow from the MOVE1 correlation equation and the measured flow at the partial-record station (predicted minus measured). The residuals are presented in plots as the percent difference between the MOVE1 predicted flow and the measured flow. The percent differences are plotted with index station flow, time, and season to examine changes in these relations. 


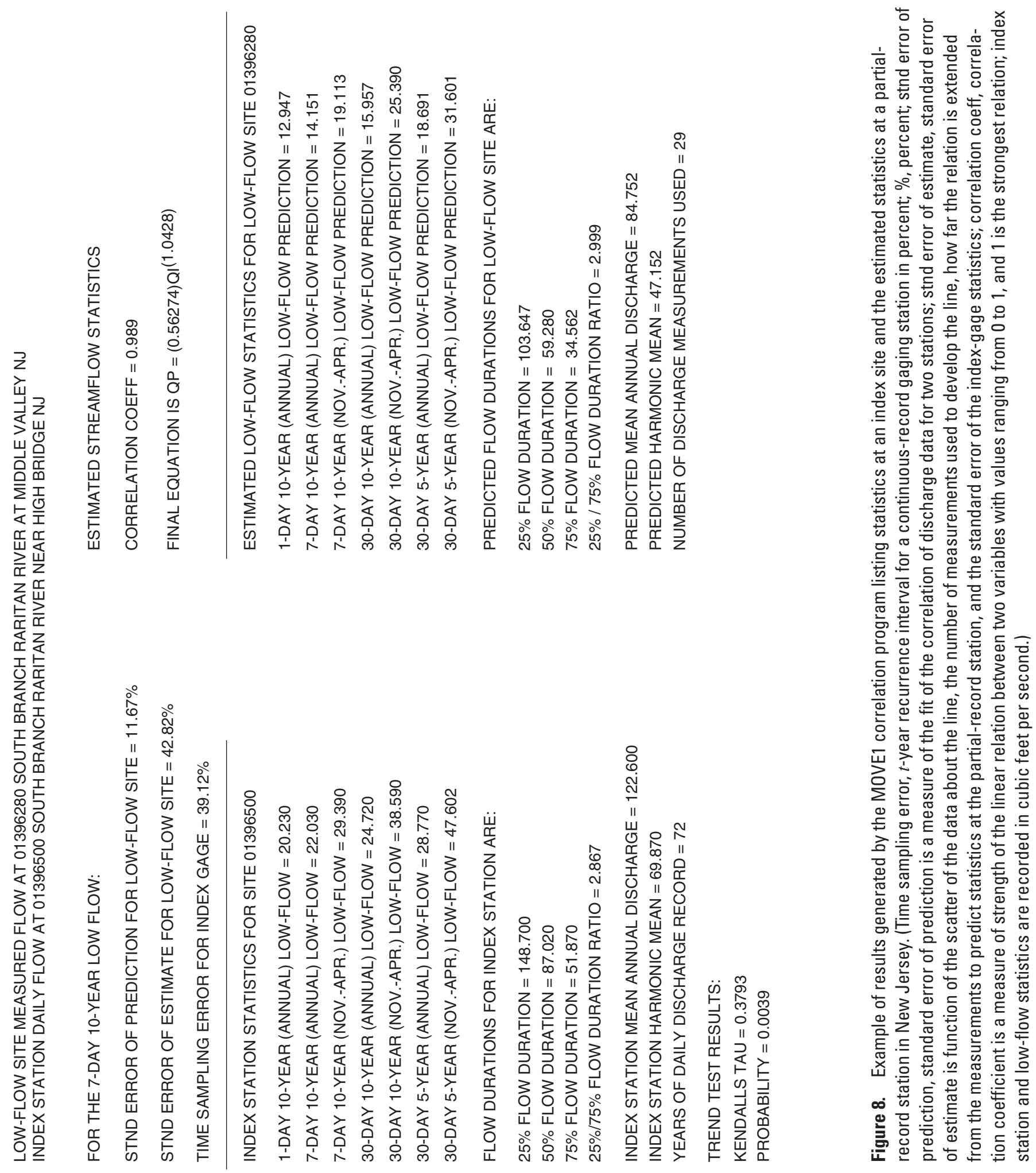




\section{LOW-FLOW CORRELATION ANALYSIS USING MOVE.1}

Partial-record site $=01396280$ Index site $={ }^{\prime} 01396500^{\prime}$

\section{$\mathbf{Q}$ at partial-record site vs $\mathbf{Q}$ at index site}

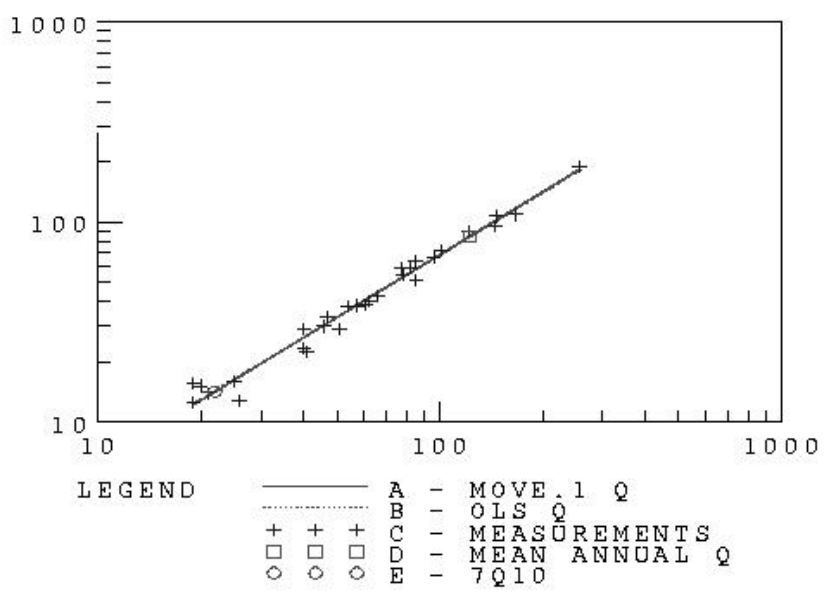

RESIDUALS vs. Time

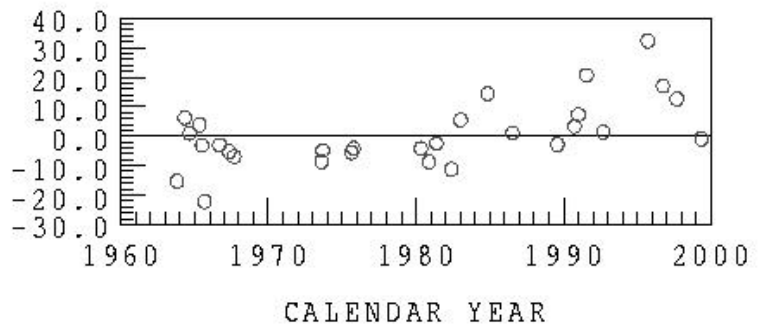

RESIDUALS vs. $Q$

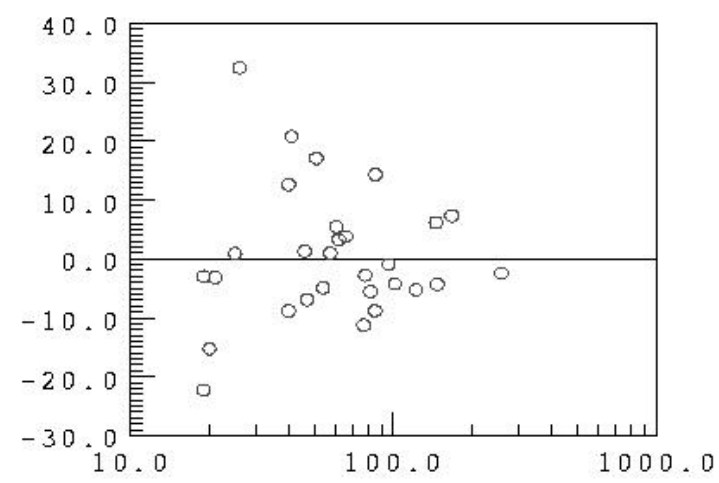

RESIDUALS vs. Month

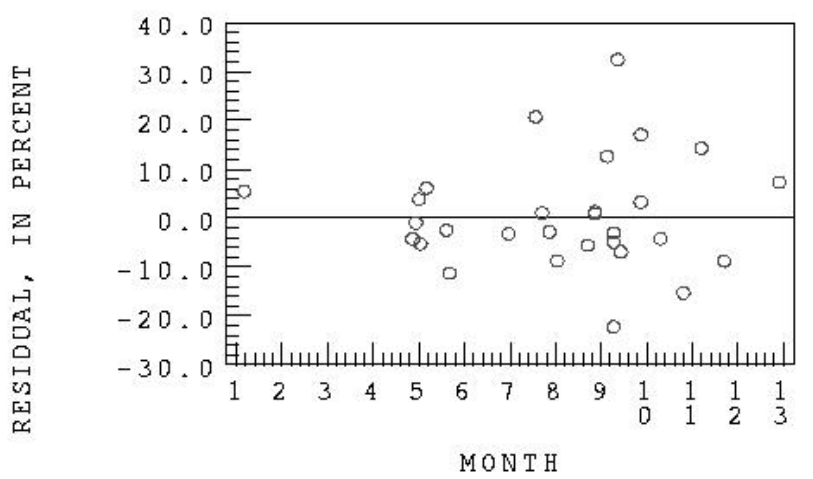

Figure 9. Example of plots generated by the Maintenance of Variance Extension Type 1 (MOVE1) correlation analysis program to evaluate the relation between base-flow measurements at a low-flow partial-record station and daily mean flow at an index site in New Jersey. ( 0 , flow in cubic feet per second; residuals, difference between predicted values and the actual values for the dependent variable; MOVE1 0 , relation between daily mean flow at $t$ streamflow-gaging station and instantaneous flow at the partial-record site; OLS, ordinary least squares; 7010, 7-day 10-year low flow.) 


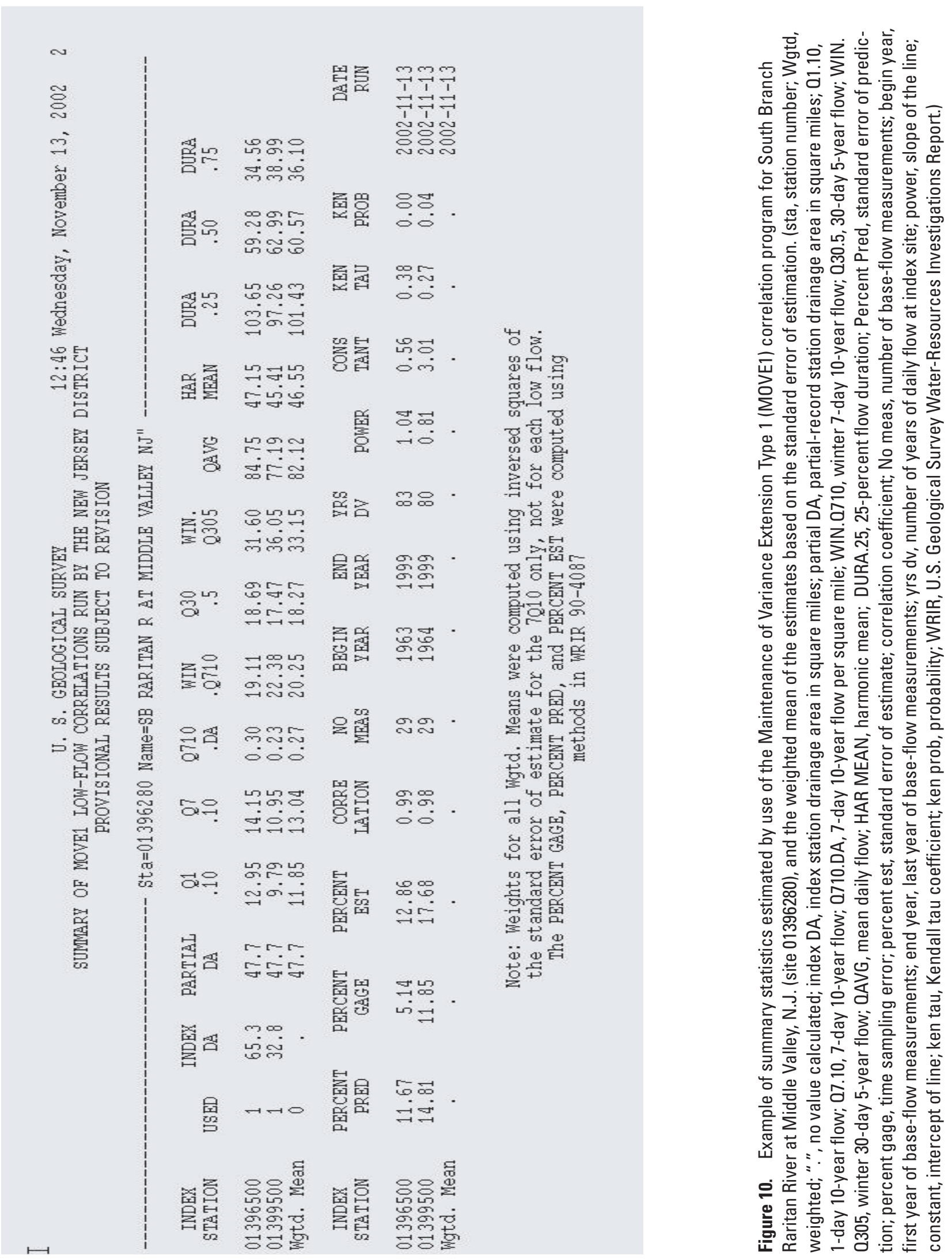


A Kendall Tau trend test is used to examine the residuals ordered from the beginning to the end of the data set. The test determines the probability that the null hypothesis of no significant trend can be rejected with a low risk of error. A $p$-value equal to 0.05 indicates there is a 95 -percent chance that a trend is present. For this study, a trend test with a $p$-value of less than or equal to 0.05 is considered a significant result. When a significant trend is detected, the data are examined more closely. If the plot of residuals in relation to time shows a noticeable shift in residuals at a particular point in time, the data after the shift may be examined separately.

The correlation between index site 01396500 and lowflow station 01396280 (fig. 1) is an example of a decrease in residuals over time or an increase in the percent difference of the predicted low flow from the measured flow. The Kendall Tau value (0.3793) and probability (0.0039) at the bottom of figure 8 show a significant positive trend in residuals. The plot of residuals in relation to time (fig. 9) shows the predicted flow from the equation as a percent difference from the actual measured flow. The plot shows a change starting in 1983. Ten of the 12 measurements after 1982 have a positive difference; flow predicted by the MOVE1 correlation equation is greater than the measured flow. Fourteen of the 17 measurements made before 1983 have a negative difference: flow predicted by the MOVE1 correlation equation is less than the measured flow. A correlation using only measurements made after 1982 would estimate lower streamflow statistics from data more indicative of recent hydrologic conditions.

The MOVE1 line does not fit the data at 9 partial-record stations. At these sites, a graphically determined best-fit line is used to determine the relation between the daily mean flows at the index gaging station and the measured flows at the partialrecord station. The MOVE1 program cannot be run directly on zero flow data because the logarithm of zero is undefined. A constant of $0.01 \mathrm{ft}^{3} / \mathrm{s}$ is added to adjust the flow at both index sites and low-flow sites to allow a logarithm to be taken. This constant can be adjusted to best fit the distribution of the nonzero flow data. The constant then is subtracted from the predicted statistics when appropriate. Another approach is to determine the frequency of flow at a nearby gaging station on the day the observed flow was zero at the low-flow site. For instance, if the flow at the gaging station is equal to the 7-day 2-year low flow (MA7CD2), it is estimated that the MA7CD2 flow and less frequently occurring non-exceedance frequencies (for example, 7-day 10-year low flow) at the low-flow site are zero.

\section{Streamflow Characteristics}

\section{Flow Statistics}

Streamflow at gaging stations is affected by changes in climate; natural factors such as river processes, sedimentation, and beaver dams; water-diversion trends, wastewater-discharge trends, and human activities. Streamflow at some gaging stations has changed over time as a result. Gaging stations with long periods of record reflect more of the inherent long-term variability of streamflow. Therefore, streamflow statistics are evaluated on the basis of the length of record and on the climatic conditions during the period of record to account for those changes.

Streamflow statistics were computed at 111 gaging stations with 20 or more years of continuous record in New Jersey and at gaging stations in surrounding States in close proximity to New Jersey. Daily mean streamflow data through water year 2001 were used for the computations at the continuous-record streamflow-gaging stations. The characteristics presented in a table of summary statistics for the long-term continuous-record stations are minimum, maximum, and daily mean streamflow; harmonic mean flow; 1-,7-, and 30day minimum average low flow with 2-, 5-, 10-, and 20-year recurrence intervals; 1-,7-, and 30-day maximum average high flow with 2-, 5-, 10-, and 25-year recurrence intervals; and 1-, 2-, 5-, 10-, 20-, 25-, 30-, 40-, 50-, 60-, 70-, 75-, 80-, 85-, 90-, 95-, 99-percent daily duration flows. The flow frequencies and flow durations are presented for both annual and winter (November through April) periods. The annual period used for frequency analysis is based on the climatic year (April 1 to March 31) for low-flow frequency analysis and the water year for high-flow frequency analysis. The annual 1-, 7-, and 30-day low- and high-flow data sets were tested for trends. Monthly, seasonal, and annual precipitation data for selected long-term meteorological stations (fig. 2) also were tested for trends to analyze the effect of climate on streamflow trends. The ratios of flow duration and high-flow to low-flow frequency, the ratio of instantaneous peak flow to 3-day mean flow, and the coefficient of variation were used to define streamflow variability.

Streamflow statistics were estimated for 500 partialrecord stations including 66 gaging stations with less than 20 years of record. MOVE1 correlation analysis was used to relate instantaneous base-flow measurements at the partialrecord stations to daily mean discharges at gaging stations. The characteristics presented for partial-record stations are daily mean flow; harmonic mean flow; and 1-, 7-, and 30-day minimum average low-flow with a 10 -year recurrence interval for the annual and winter periods.

Streamflow statistics are presented in tables for each continuous-record streamflow-gaging station and partial-record station. The tables are available at the USGS World Wide Web site http://pubs.water.usgs.gov/sir20055105/. The tables are updated as new data become available. An example of the presentation of summary statistics for South Branch Raritan River near High Bridge, N.J. (01396500), a continuous-record streamflow-gaging station with more than 20 years of record is shown in figure 11. Section A begins with the basin name from the NJDEP list of 20 Watershed Management Areas (WMA's) in the State. The WMA is followed by the USGS station identification number. Each continuous-record streamflow-gaging station is assigned a unique identification number, which 


\begin{tabular}{|c|c|}
\hline AORTH AND SOUTH BRANCH RARITAN BASIN \\
01396500 South Branch Raritan River near High Bridge, NJ
\end{tabular}

\section{B}

Location: $\quad$ Latitude $40^{\circ} 40^{\prime} 40^{\prime \prime}$, Longitude $74^{\circ} 52^{\prime} 45^{\prime \prime}$, Hunterdon County, Hydrologic Unit 02030105, on left bank 1.0 mi northeast of High Bridge, and 4.4 mi upstream from Spruce Run.

Drainage area: $\quad 65.3 \mathrm{mi}^{2}$

Station type: Continuous-record gaging station

Period of record: $\quad 1919-2001$

\begin{tabular}{|lcccc|}
\hline C & \multicolumn{3}{c|}{ Streamflow characteristics (cfs) } \\
Period of record: & Mean annual flow & Minimum daily flow & Maximum daily flow & Harmonic mean flow \\
$1919-2001$ & 123 & 13 & 3,340 & 70 \\
\hline
\end{tabular}

\begin{tabular}{|c|c|c|c|c|c|c|c|c|c|c|c|}
\hline \multirow{2}{*}{$\begin{array}{l}\text { D } \\
\text { Period } \\
\text { of } \\
\text { record }\end{array}$} & \multicolumn{5}{|c|}{$\begin{array}{l}\text { Magnitude and frequency of lowflow } \\
\text { for indicated periods }\end{array}$} & \multicolumn{6}{|c|}{$\begin{array}{c}\text { E Magnitude and frequency of high flow } \\
\text { for indicated periods }\end{array}$} \\
\hline & \multirow{2}{*}{$\begin{array}{c}\text { Number of } \\
\text { consecutive } \\
\text { days }\end{array}$} & \multicolumn{4}{|c|}{$\begin{array}{l}\text { Annual minimum streamflow (cfs) } \\
\text { for indicated recurrence interval } \\
\text { in years }\end{array}$} & \multirow{2}{*}{$\begin{array}{l}\begin{array}{l}\text { Period } \\
\text { of } \\
\text { record }\end{array} \\
1919-2001\end{array}$} & \multirow[t]{2}{*}{$\begin{array}{l}\text { Number of } \\
\text { consecutive } \\
\text { days }\end{array}$} & \multicolumn{4}{|c|}{$\begin{array}{c}\text { Annual maximum streamflow (cfs) } \\
\text { for indicated recurrence interval } \\
\text { in years }\end{array}$} \\
\hline $1920-2001$ & & 2 & 5 & 10 & 20 & & & 2 & 5 & 10 & 25 \\
\hline Annual & 1 & 31 & 24 & 20 & 18 & Annual & 1 & 1,070 & 1,540 & 1,890 & 2,360 \\
\hline \multirow[t]{2}{*}{ (Apr.-Mar.) } & 7 & 33 & 26 & 22 & 19 & \multirow[t]{2}{*}{ (Oct.-Sept.) } & 7 & 473 & 641 & 752 & 891 \\
\hline & 30 & 38 & 29 & 25 & 22 & & 30 & 278 & 362 & 415 & 479 \\
\hline \multirow{3}{*}{$\begin{array}{l}\text { Winter } \\
\text { (Nov.-Apr.) }\end{array}$} & 1 & 43 & 32 & 27 & 23 & \multirow{3}{*}{$\begin{array}{l}\text { Winter } \\
\text { (Nov.-Apr.) }\end{array}$} & 1 & 905 & -- & 1,720 & 2,250 \\
\hline & 7 & 50 & 35 & 29 & 25 & & 7 & 408 & 578 & 703 & 876 \\
\hline & 30 & 70 & 48 & 39 & 32 & & 30 & 259 & 347 & 406 & 481 \\
\hline
\end{tabular}

F

Period of

record

Duration of daily flow

\begin{tabular}{|lllllllllllllllllll} 
record & 1 & 2 & 5 & 10 & 20 & 25 & 30 & 40 & 50 & 60 & 70 & 75 & 80 & 90 & 95 & 98 & 99 & \\
\hline $1919-2001$ & & & & & & & & & & & & & & & & & & \\
Annual & 676 & 513 & 338 & 242 & 169 & 149 & 133 & 107 & 87 & 71 & 58 & 52 & 46 & 36 & 29 & 24 & 22 \\
Winter & 732 & 574 & 397 & 283 & 205 & 183 & 166 & 140 & 118 & 100 & 83 & 75 & 68 & 51 & 40 & 32 & 28 \\
\hline
\end{tabular}

Figure 11. Example of summary statistics for continuous-record streamflow-gaging stations in New Jersey with 20 or more years of continuous streamflow record. (This example represents summaries as they are presented on the World Wide Web site. Identifying letters A, B, C, D, E, and F are used only to facilitate discussion in the text. mi, miles; mi2; square miles; cfs, cubic feet per second; ,-- no value calculated.) 
follows the "downstream order" system. The gaging station name is included in this table as well as the WMA name.

Section B is a description of the gaging station, including the location. The drainage area of the gaging station is recorded in square miles $\left(\mathrm{mi}^{2}\right)$. The station type is continuous-record gaging station. A continuous-record gaging station records streamflow data at regular intervals throughout the day. The data, usually collected at 15-minute intervals, are used to compute daily mean-flow values. Gaging stations with less than 20 years of record were analyzed as partial-record stations and are labeled as such. The period of record is given in water years starting with the first complete year of record at that station.

Section C displays streamflow characteristics. In these summary statistics, cubic feet per second is abbreviated as cfs. This table contains five basic statistics for streamflow at the gaging station. The period of record for the station is in water years. Mean annual flow is the arithmetic mean of the individual daily mean discharges for the designated period. The minimum flow value is the minimum instantaneous discharge for the period of record. The maximum flow value is the maximum instantaneous discharge for the period of record. The value for harmonic mean flow is a statistic used as a design flow applied to water-quality criteria for the protection of human health under lifetime exposure to toxic contaminants (Rossman, 1990). Some gaging stations may have a split period of record as a result of the augmentation of regulation or the withdrawal of regulation.

Section D provides the magnitude and frequency of low flow for indicated periods separated into two categories, annual and winter. The period of record for annual low-flow data follows the climatic year, April through March, where the numeric year corresponds with January through March. Winter data are collected from November through April. The annual minimum streamflow for the indicated recurrence interval in years is listed in this table. For low-flow statistics, the recurrence interval is $2,5,10$, and 20 years.

Section E presents the magnitude and frequency of high flow for indicated periods separated into annual and winter. The period of record for high-flow data follows the water year, October through September. Winter data are collected from November through April. This table lists the annual maximum streamflow for the indicated recurrence interval in years. For high-flow statistics, the recurrence interval is $2,5,10$, and 25 years.

Section F presents the duration of daily flow, which is the output from the flow-duration curve. The flow-duration curve is a cumulative-frequency curve that shows the percentage of time that specified discharges are exceeded. The curve is based on the total period of record (water year), but the chronological sequence of flows is omitted from consideration in the preparation of the curve. Therefore, it is impossible to tell from the flow-duration curve alone whether varying periods of low flow all occurred during one drought period or were scattered over a number of years. The flow-duration curve is, however, useful for studying the flow characteristics of a stream over its entire range of discharge (Gillespie and Schopp, 1982).

An example of the presentation of estimated statistics for South Branch Raritan River at Middle Valley, N.J. (01396280), a low-flow partial-record station, is shown in figure 12. Instantaneous base-flow measurements are correlated to daily mean flow at gaging stations in basins with similar hydrologic conditions. The low-flow statistics were estimated by using the Maintenance of Variance Extension Type 1 (MOVE1) method of correlation analysis (Hirsch, 1982) when ample base-flow measurements were available. Section A identifies of the station name and USGS station identification number, a unique identification number that follows the "downstream order" system. The WMA name from the NJDEP list of $20 \mathrm{WMA}$ in the State also is displayed.

Section B is a description of the partial-record station, including the location. The drainage area of the partial-record station is recorded in square miles $\left(\mathrm{mi}^{2}\right)$. The station type is low-flow partial-record station (partial-record station), or gaging station analyzed as partial-record station. A partial-record station is a site where discrete measurements are obtained over a period of time without continuous data being recorded or computed (Reed and others, 2003). The period of record is given in water years. Remarks identify stations used for the statistical correlations and the rating given to the subject station for the confidence of the correlations. A rating of good, fair, or poor is assigned to the estimates for each partial-record site. A weighted mean of the individual standard errors of estimate for each correlation is used to rate the estimated statistics. A frequency distribution of all the weighted mean standard errors is used as a guide for rating the estimates for each site. All sites with weighted mean errors less than the $50^{\text {th }}$ percentile are rated good. Sites with weighted mean errors from the $50^{\text {th }}$ to the $75^{\text {th }}$ percentile are rated fair, and sites with errors greater than the $75^{\text {th }}$ percentile are rated poor. Ratings of good, fair, and poor correspond to the standard errors of prediction of less than 45 percent, 45 percent to 143 percent, and greater than 143 percent, respectively.

Section C presents streamflow characteristics. In these summary statistics, cubic feet per second is abbreviated as cfs. Three basic statistics for a partial-record station are given in this table. The period of record for these statistics is in water years and is the period of record of base-flow measurements for that station. Mean annual flow is the arithmetic mean of the individual daily mean discharges for the designated period. The value for harmonic mean flow is a statistic used as a design flow applied to water-quality criteria for the protection of human health under lifetime exposure to toxic contaminates (Rossman, 1990).

Section D is the magnitude and frequency of low flow for indicated periods separated into two categories, annual and winter. The period of record for low-flow data follows the climatic year, April through March. Winter data are collected from November through April. The annual minimum streamflow for a 10-year recurrence interval is listed in this table. 
A

NORTH AND SOUTH BRANCH RARITAN BASIN

01396280 South Branch Raritan River at Middle Valley, NJ

\section{B}

Location: $\quad$ Latitude $40^{\circ} 45^{\prime} 40^{\prime \prime}$, Longitude $74^{\circ} 49^{\prime} 17^{\prime \prime}$, Morris County, Hydrologic Unit 02030105, at bridge in Middle Valley, 6.9 mi downstream from Drakes Brook.

Drainage area: $\quad 47.7 \mathrm{mi}^{2}$

Station type: Low-flow partial-record station

Period of record: $\quad 1963-1999$

Remarks: Low-flow frequency estimates are based on correlations with gaging stations 01396500, 01398500 , and 01399500. The correlations are considered good.

\begin{tabular}{|c|c|c|c|}
\hline \multirow[t]{2}{*}{ C } & \multicolumn{3}{|c|}{ Estimated streamflow characteristics (cfs) } \\
\hline & Period of record & Mean annual flow & Harmonic mean flow \\
\hline & 1963-1999 & 82 & 47 \\
\hline
\end{tabular}

\begin{tabular}{|ccc|}
\hline $\begin{array}{c}\text { Magnitude and frequency of low flow for indicated periods } \\
\text { Period } \\
\text { of } \\
\text { record } \\
\text { 1963-1999 }\end{array}$ & $\begin{array}{c}\text { Number of } \\
\text { consecutive } \\
\text { days }\end{array}$ & $\begin{array}{c}\text { Annual minimum } \\
\text { streamflow (cfs) for a 10- } \\
\text { year recurrence interval }\end{array}$ \\
\hline Annual & & \\
(Apr.-Mar.) & 1 & 12 \\
& 7 & 13 \\
\hline Winter & 30 & 15 \\
(Nov.-Apr.) & 1 & 20 \\
& 7 & 27 \\
\hline
\end{tabular}

Figure 12. Example of summary statistics for low-flow partial-record stations in New Jersey. (This example represents summaries as they are presented on the World Wide Web site. Identifying letters $A, B, C$, and $D$ are used only to facilitate discussion in the text. mi, miles; mi2; square miles; cfs, cubic feet per second.) 
The standard error of estimate computed from the standard error of prediction of the MOVE1 line, and the error associated with statistics computed for the index sites, were used as measures of accuracy for estimates of summary statistics at the partial-record stations.

Harmonic mean flow was computed for all the continuous-record streamflow-gaging stations with 10 or more years of record and estimated for all partial-record stations. The statistic was computed for two separate periods of record at 20 gaging stations with 20 or more years for each separate period of record with a change in flow regulation at a given point in time. Harmonic mean flow for gaging stations ranged from 6,347 $\mathrm{ft}^{3} / \mathrm{s}$ at Delaware River at Trenton, N.J. (01463500) (fig. 2) to $0.17 \mathrm{ft}^{3} / \mathrm{s}$ at Back Brook Tributary near Ringoes, N.J. (01398045) (fig. 1).

Harmonic mean flows at gaging stations were compared to statistics of flow duration and low-flow frequency by evaluating the percent differences at each site and by using ordinary least squares regression. This analysis was done to investigate other flow statistics that could be used as alternatives to the harmonic mean flow. Harmonic mean flow cannot be transferred accurately from one site on a stream to another site. The proportional adjustment used for zero flows is another limitation of using harmonic mean flow as a design-flow criterion. The adjustment was found to yield illogical results when low-flow values of zero or close to zero were changed slightly (Martin and Ruhl, 1993).

Linear relations between harmonic mean flow and 50-, 60-, 70-, 75-, 80-, 90-, 95-percent flow durations and 7day 10-year and 7-day 2-year low flows were evaluated for comparability. All the relations with flow durations between 60- and 90-percent had $\mathrm{r}^{2}$ values greater than 0.97 , when all gaging stations for all periods of record were analyzed. The relations with low-flow frequency statistics resulted in lower $\mathrm{r}^{2}$ values.

Harmonic mean flows from individual gaging stations and from groups of gaging stations in close proximity geographically and(or) hydrologically were closest to flows ranging from 60- to 90-percent flow duration. Statistically the 75-percent flow duration is most closely associated with harmonic mean flow when evaluating all the gaging stations analyzed in this study (fig. 13). The 70-and 75-percent flow durations are closest to the harmonic mean flow. The harmonic mean averages 12 percent higher than the 75-percent flow duration and 2.5 percent less than the 70-percent flow duration. Differences at individual gaging stations range from 54 percent higher to 88 percent lower than the 75 -percent flow and from 32 percent higher to 89 percent lower than the 70-percent flow. The regression analyses yield similar results; $\mathrm{r}^{2}$ values were 0.999 and 0.997 when using untransformed values and 0.969 and 0.972 when using log-transformed values. The root mean square error was 61 percent for the regression with 70-percent flow duration and 38 percent for the regression with 75-percent flow duration. The 75-percent flow duration is considered to be the best alternative to the harmonic mean flow when making comparisons on a statewide basis. These statistics vary by 40 percent or more for only a few gaging stations on highly regulated streams and a few gaging stations on streams in the Piedmont Physiographic Province with drainage areas less than $10 \mathrm{mi}^{2}$.

Harmonic mean flow was less than the 50-percent flow duration at all gaging stations for all periods of record analyzed. The harmonic mean flow was greater than the 90-percent flow duration at all gaging stations except two on the highly regulated Delaware \& Raritan Canal and Lawrence Brook (fig. 1). Harmonic mean flow was greater than the 80 -percent flow duration at all gaging stations except those with reservoir regulation and most gaging stations draining areas less than $10 \mathrm{mi}^{2}$ in the Piedmont Physiographic Province. Harmonic mean flow was greater than the 75-percent flow and the 70-percent flow for more than 75 percent and 35 percent of the gaging station periods of record analyzed, respectively.

The harmonic mean flow was within 10 percent of the 60-percent flow duration at most gaging stations without substantial regulation in the Coastal Plain. At most gaging stations, the two statistics agreed within 5 percent. At four gaging stations in the outer Coastal Plain along the Atlantic Ocean, however, the harmonic mean flow was more than 30 percent lower than the 60-percent flow duration. The harmonic mean flow at these sites was within 10-percent of the 70-percent flow duration.

The harmonic mean flow was also within 10 percent of the 60-percent flow duration at unregulated gaging stations on the Lamington River, Mulhockaway Creek, Musconetcong River, Pequest River, South Branch Raritan River, Spruce Run, and Whippany River (fig. 1) in the New England Physiographic Province. Also, harmonic mean flows at gaging stations on the Elizabeth River, Second River, and Third River (fig. 1) in the Piedmont Physiographic Province in northeastern New Jersey were within 10 percent of the 60-percent flow duration. At regulated gaging stations on the Assunpink Creek (fig. 2), Delaware River, Hackensack River, Pompton River, Raritan River, Saddle River, and South Branch Raritan River (fig. 1) harmonic mean flows were within 13 percent of the 60-percent flow. Harmonic mean flows were less than the 60-percent flow duration at most unregulated gaging stations in the Piedmont and Valley and Ridge Physiographic Provinces.

Harmonic mean flows matched the 70-percent flow duration to within 10 percent at all four unregulated gaging stations on the Flat Brook, Paulins Kill, Pequest River, and Wallkill River (fig. 1) in the Valley and Ridge Physiographic Province. There are no clear similarities in physiographic province or flow regulation at the remaining gaging stations where the harmonic mean flows were closest to the 70-, 75-, or 80-percent flow durations. The gaging stations in each group are located across different regions of the State and on streams with and without regulation.

The harmonic mean flow was closest to the 90-percent flow at seven gaging stations in the Piedmont Physiographic Province. Four of the gaging stations monitor unregulated flow; three of these gaging stations measure flow draining 


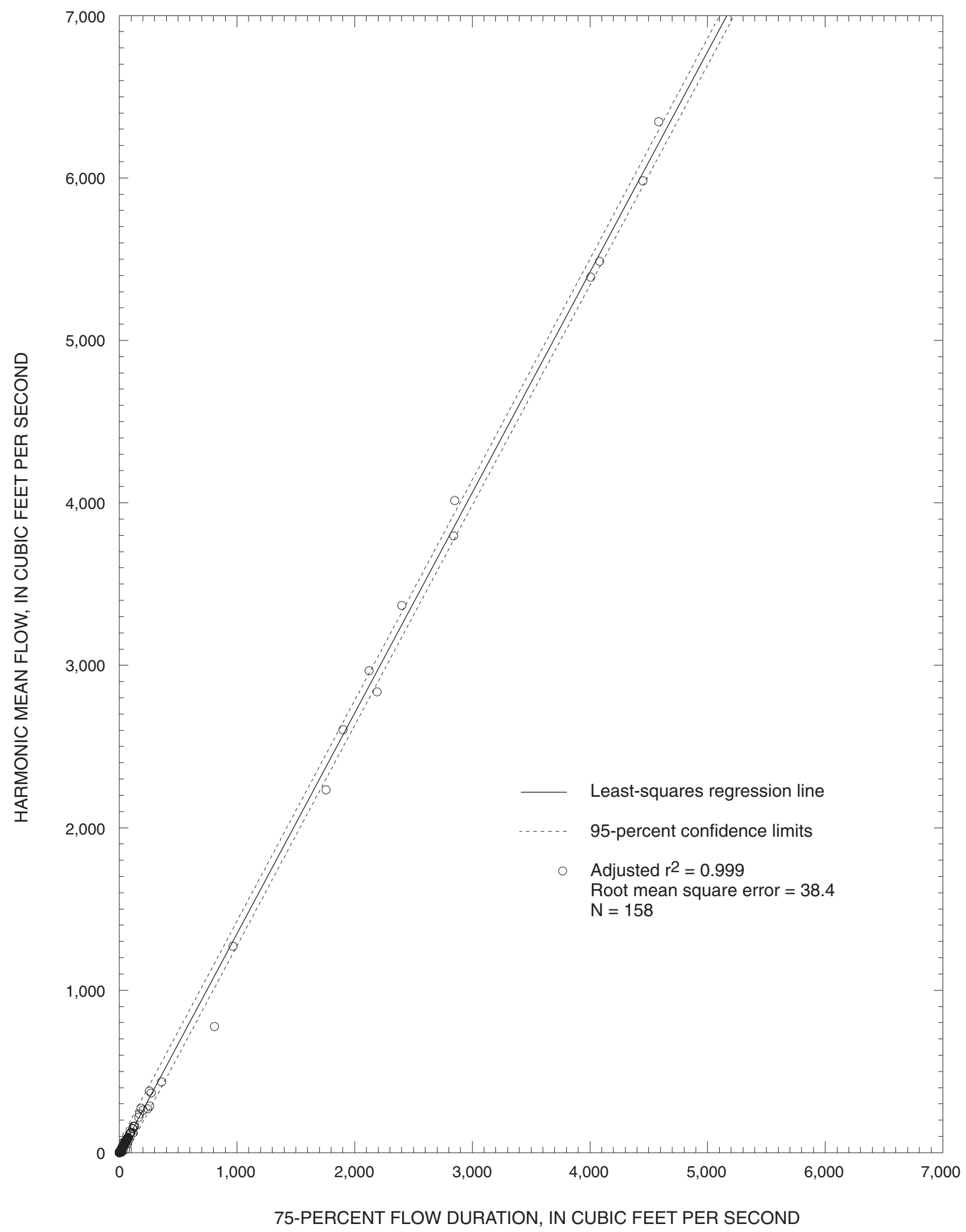

Figure 13. Relation of harmonic mean flow to 75-percent flow duration for 158 periods of record at 138 gaging stations with greater than 10 years of record on selected streams in New Jersey. ( $r^{2}$, correlation coefficient; N, number of records.) 
from less than $2.5 \mathrm{mi}^{2}$, and one gaging station measures flow draining from $7 \mathrm{mi}^{2}$. The other three gaging stations in the Piedmont Physiographic Province are on regulated streams.

\section{Streamflow Variability}

Streamflow variability as defined by the ratios of 25-percent/75-percent and 10-percent/90-percent flow durations, and the ratios of 1-day 2-year high flow/1-day 2-year low flow and 1-day 20-year high flow /1-day 20-year low flow was analyzed for all gaging stations with 10 or more years of record. Ratios at gaging stations in the Coastal Plain were compared with ratios at gaging stations located outside of the Coastal Plain. Comparisons also were made between gaging stations grouped by land-use category in the Coastal Plain and other physiographic provinces. Gaging stations affected by substantial regulation were removed from the groups before making comparisons.

Streamflow variability was substantially greater among the group of gaging stations located outside the Coastal Plain than the group of gaging stations located in the Coastal Plain. The median value of the 25-percent/75-percent ratio was 4.12 for the 38 analyzed stations outside the Coastal Plain and 2.16 for the 20 analyzed stations in the Coastal Plain. All four ratios were substantially higher for the group of gaging stations outside the Coastal Plain than for the group of gaging stations inside the Coastal Plain.

Streamflow variability was compared between gaging stations in different land-use categories. Gaging stations with greater than 30 percent of their drainage area categorized as developed land were compared with gaging stations with 70 percent or more of their land area categorized as undeveloped. Ratios of 1-day 2-year high flow/1-day 2-year low flow and 1-day 20-year high flow /1-day 20-year low flow were substantially higher at gaging stations draining developed basins than at gaging stations draining undeveloped basins in the Coastal Plain, indicating more variability in flow. No considerable differences in ratios of flow duration were observed between gaging stations in developed and undeveloped basins in the Coastal Plain. No considerable differences in streamflow variability were observed between the groups of gaging stations in developed and undeveloped basins located outside the Coastal Plain.

Developed sites were categorized as urban, agricultural, or mixed. Gaging stations with greater than 16-percent agricultural land were categorized as agricultural sites, and those with greater than 40-percent urban land use were categorized as urban sites. The ratios of high-flow to low-flow frequency were considerably different for gaging stations at undeveloped sites and both urban and agricultural sites in the Coastal Plain. Gaging stations that monitor flows from agricultural and urban areas had substantially higher streamflow variability than gaging stations with flows from undeveloped areas.

The coefficient of variation is another indicator of streamflow variability used to quantify the variability of daily mean streamflow. Streams with the lowest coefficient of variation have the least variability in daily mean streamflow. The coefficient of variation was highest (from 207 to 405) for small unregulated streams in the southern area of the Piedmont Physiographic Province and lowest (from 41 to 93) for streams in the Pinelands area (fig. 5) of the Coastal Plain. The only gaging station with a coefficient of variation lower than the gaging stations in the Pinelands region was the Delaware and Raritan Canal at Port Mercer (01460440) (fig. 2), which had a value of 16.7. The flow in the Delaware and Raritan Canal is regulated at a fairly constant rate for water-supply purposes. Streams in the Pinelands region have lower variability in daily mean flow than streams in other areas of New Jersey because a high percentage of total annual streamflow originates from ground water. Base flow accounts for 70 to 90 percent of mean annual flow at these gaging stations ( $\mathrm{CH} 2 \mathrm{M}$ Hill and others, 1992). Base flow accounts for approximately 30 to 50 percent of mean annual flow at the gaging stations with the highest coefficients of variation.

Gaging stations on the Lamington River, Pequest River, and Musconetcong River (fig. 1) are the only sites, other than those in the Coastal Plain, with coefficients of variation less than 100. Base flow in these streams is a higher percentage of mean annual flow (78-84 percent) than in most other streams in the study area, except those in the Pinelands area $(\mathrm{CH} 2 \mathrm{M}$ Hill and others, 1992). The only other sites outside the Piedmont Physiographic Province with a coefficient of variation greater than 200 are on the Salem River (fig. 2) in an agricultural area of the inner Coastal Plain, on Blue Mine Brook (fig. 1) in an undeveloped area of the New England Physiographic Province, and at four gaging stations on regulated streams scattered across the study area.

\section{Trends in Streamflow}

The goals of the streamflow trend analysis were to determine whether there were trends in specific annual $n$-day high flows and low flows and to provide a general assessment of the effects that development in watersheds upstream from streamflow-gaging stations could have on the trend results. A general assumption is that increased development in a watershed would result in lower streamflows during dry weather and higher streamflows during storms. Some of the factors that can cause these effects on streamflow are an increase in impervious cover, an increase in water use, an increase in stormwaterdrainage systems, and an increase in wastewater sewers and treatment facilities. Development patterns in New Jersey have left a few watersheds that have been sparsely developed over the past 40 years, and much of this development has occurred upstream from the gaging stations used in this analysis.

Trend analysis was done for 138 gaging stations with a total of 159 different records. For 20 stations, the period of record (length of time that data is collected at a gaging station) was often split into two periods as a result of substantial hydrologic changes in the watershed upstream from the 
station (for example, dams, diversions, wastewater discharges). Streamflow data through water year 2001 were used for the computations at the continuous-record stations. The Kendall Tau trend test was conducted with SWSTAT, a surface-water statistics program (Flynn, 1995), to analyze the annual 1-, 7-, and 30-day high- and low-flow data sets. The outcomes for each record were a Kendall Tau coefficient, a $p$-value, and a slope for each of the annual $n$-day high- and low-flow periods (table 3 and 4 [back of report]), the actual values are listed in appendix 3A-B). When the Kendall Tau coefficient is negative, there is a downward trend. When the Tau is positive, there is an upward trend. The $p$-value determines the significance of the results. A $p$-value equal to or less than 0.05 is considered a significant result. The results for three categories of gagingstation record-all gaging stations, regulated gaging stations, and unregulated gaging stations-for the 1-, 7-, and 30-day high- and low-flow are summarized in table 5a. The number and percentage of gaging stations with significant upward and downward trends are presented for each $n$-day flow condition in table $5 b$.

A stream is considered regulated if changes in the hydrologic characteristics of the drainage basin (reservoir, large sewage-treatment-plant discharge, large surface-water diversions) upstream from the gaging station could have a substantial effect on low flows and in some cases on high flows (Robert Schopp, U.S. Geological Survey, written commun., 2003). The unregulated gaging stations are those with manmade hydrologic changes in the drainage basin upstream from the gaging stations that are not considered substantial enough to affect low-flow statistics. Although these gaging stations are considered to be unregulated for this analysis, there have been some hydrologic modifications (ground-water diversions for example, wastewater-treatment facilities) over the period of record for some of the gaging stations. The designation of gaging stations as regulated or unregulated will be re-evaluated for any possible future flow-trend analysis studies performed by the USGS.

Trend results indicate upward trends at most sites for the annual 1-, 7-, and 30-consecutive-day high flows based on the Kendal Tau analysis; but not all results were statistically significant. The significant results for the 1- and 7-day high flows for records from all gaging stations indicate most trends were upward, but trends for 30-day high flows were almost evenly split. Five gaging stations had upward trends and six gaging stations had downward trends (table 5b). The percentages of all records with significant high-flow trends were 16, 11, and 7 for the 1-, 7-, and 30-day flows, respectively. The low-flow trends were essentially even for all records for each flow regime. The significant low-flow trend results for all records for all flow regimes were upward trends, though the 7-day flow was close to evenly split. The percentages of all records with significant low-flow trends were 25, 25, and 19 for the 1-, 7-, and 30-day periods, respectively.

Of the total 159 records, 86 records were for regulated gaging stations (appendix 1-A). Trend test results indicate an upward trend for the 1-, 7-, and 30-day high flows at most reg- ulated gaging stations. Not all results were significant. Of the significant results, trends were mostly upward for the 1- and 7-day high flows, and for the 30-day high flows, four trends were downward and three were upward. The percentages of regulated gaging stations with significant trends were 19, 13 , and 8 for the 1-, 7-, and 30-day high flows, respectively. Most of the low-flow trends for the regulated gaging stations were upward, and the significant results represent a relatively large percentage of the gaging station records compared with the results for the unregulated gaging station records. For the 1-, 7-, and 30-day low flows, the percentages of regulated gaging stations with significant results were 28, 33, and 26, respectively. It was expected that the statistics for low flows at regulated gaging stations might not be consistent with those for the unregulated stations, but it was not expected that most of the significant trend results for the low flows tested would be upward. An example of a regulated gaging station is Saddle River at Lodi (01391500), which has upward low-flow trends and upward high-flow trends. One factor that could have affected these trends is the addition of a major sewage-treatment plant upstream from the gaging station. Other factors that could affect the trend analysis are discussed below.

Seventy-three of the 159 periods of record analyzed are for unregulated gaging stations (appendix 1-A). Trend test results indicate an upward trend for the 1-, 7-, and 30-day high flows at most unregulated gaging stations. The significant high-flow trends were mainly upward for the 1- and 7-day flows. The significant 30-day flows were evenly split between upward and downward trends. The percentages of unregulated gaging stations with significant high-flow trends were 14, 12 , and 5 for the 1-, 7-, and 30-day flows, respectively. Trend test results indicate a downward trend for the 1-, 7-, and 30-day low flows at most unregulated gaging stations. Most significant results were determined to be downward for the 7- and 30-day flows, and the 1-day flows were evenly split. The percentages of unregulated gaging stations with significant low-flow trends were 22, 16, and 12 for the 1-, 7-, and 30-day, respectively.

Fourteen gaging stations in the unregulated gaging station data set are on streams with little developed land (less than 15-percent) upstream from the gaging station; the streams are considered to be natural streams because the areas they drain are undeveloped (table 2). Because of the sparse development upstream from these sites, changes in streamflow trends at these sites would be related more to climate or precipitation than to regulation or development. The trends for high flows were almost evenly split between upward and downward. Only one trend for high flows was significant, and it was an upward trend for the 7-day flow. The low-flow trends were mostly downward (11 out of 14 gaging stations) with three significant downward trends each for the 1-, 7-, and 30-day low flows and one significant upward trend result for the 1-day low flow. The unregulated gaging stations with greater than 15-percent developed land had mostly upward trends for the high flows, and the significant results also were mostly upward. Most of the low-flow trends were downward, but the significant low- 
Table 5a. Results of trend tests on records of highest and lowest annual $n$-day flow for streamflow-gaging stations in New Jersey.

$[n$, number of streamflow-gaging records; + , positive Kendall Tau value; - , negative Kendall Tau value; significant $=p$-value $<0.05]$

\begin{tabular}{|c|c|c|c|c|c|c|}
\hline \multirow{3}{*}{ Number of records } & \multicolumn{6}{|c|}{ Trend tests } \\
\hline & \multicolumn{2}{|c|}{ 1-Day } & \multicolumn{2}{|c|}{ 7-Day } & \multicolumn{2}{|c|}{ 30-Day } \\
\hline & Trend & $\begin{array}{c}\text { Percent } \\
(n)\end{array}$ & Trend & $\begin{array}{c}\text { Percent } \\
(n)\end{array}$ & Trend & $\begin{array}{c}\text { Percent } \\
(n)\end{array}$ \\
\hline & \multicolumn{6}{|c|}{ Annual high-flow trends } \\
\hline All gaging station records $n=159$ & + & $57(90)$ & + & $57(91)$ & + & $55(88)$ \\
\hline Regulated gaging station records $n=86$ & + & $62(53)$ & + & $57(49)$ & + & $55(47)$ \\
\hline \multirow[t]{2}{*}{ Unregulated gaging station records $n=73$} & + & $58(42)$ & + & $58(42)$ & + & $56(41)$ \\
\hline & \multicolumn{6}{|c|}{ Annual low-flow trends } \\
\hline All gaging station records $n=159$ & + & $56(89)$ & - & $51(81)$ & + & $50(80)$ \\
\hline Regulated gaging station records $n=86$ & + & $63(54)$ & + & $59(51)$ & + & $59(51)$ \\
\hline Unregulated gaging station records $n=73$ & - & $52(38)$ & - & $63(46)$ & - & $60(44)$ \\
\hline
\end{tabular}

Table 5b. Significant results of trend tests on records of highest and lowest annual $n$-day flow for streamflow-gaging stations in New Jersey.

$[n$, number of streamflow gaging records; + , positive Kendall Tau value; - , negative Kendall Tau value; significant $=p$-value $<0.05]$

\begin{tabular}{|c|c|c|c|c|c|c|c|c|c|}
\hline & \multicolumn{9}{|c|}{ Trend tests } \\
\hline & \multicolumn{3}{|c|}{ 1-Day, significant } & \multicolumn{3}{|c|}{ 7-Day, significant } & \multicolumn{3}{|c|}{ 30-Day, significant } \\
\hline & $\begin{array}{c}\text { Number of } \\
\text { stations }\end{array}$ & Trend & $\begin{array}{c}\text { Percent } \\
(n)\end{array}$ & $\begin{array}{l}\text { Number of } \\
\text { stations }\end{array}$ & Trend & $\begin{array}{c}\text { Percent } \\
(n)\end{array}$ & $\begin{array}{c}\text { Number of } \\
\text { stations }\end{array}$ & Trend & $\begin{array}{c}\text { Percent } \\
(n)\end{array}$ \\
\hline & \multicolumn{9}{|c|}{ Annual high-flow trends } \\
\hline All gaging stations & 26 & + & $77(20)$ & 18 & + & $78(14)$ & 11 & - & $55(6)$ \\
\hline Regulated gaging stations & 16 & + & $69(11)$ & 11 & + & $73(8)$ & 7 & - & $57(4)$ \\
\hline \multirow[t]{2}{*}{ Unregulated gaging stations } & 10 & + & $90(9)$ & 9 & + & $78(7)$ & 4 & - & $50(2)$ \\
\hline & \multicolumn{9}{|c|}{ Annual low-flow trends } \\
\hline All gaging stations & 40 & + & $68(27)$ & 40 & + & $53(21)$ & 31 & + & $61(19)$ \\
\hline Regulated gaging stations & 24 & + & 79 (19) & 28 & + & $61(17)$ & 22 & + & $68(15)$ \\
\hline Unregulated gaging stations & 16 & + & $50(8)$ & 12 & - & $67(8)$ & 9 & - & $56(5)$ \\
\hline
\end{tabular}


flow trends were mixed. Of the 1-day low flow trends, seven were upward and five were downward. Of the 30-day low flow trends, four were upward and two downward, and of the 7-day low-flow trends, four were upward and five were downward.

The overall results of the trends analysis show that highflow trends for the regulated and unregulated gaging stations were upward. The gaging stations with significant trend results also showed an upward trend for the regulated and unregulated gaging stations for the 1- and 7-day flows, whereas the 30-day flows were approximately evenly split between upward and downward trends. The trend results for the unregulated gaging stations at sties identified as undeveloped did not show highflow trends. The high-flow trend results indicate a relation between upward high-flow trends and stream regulation and development. An increase in development leads to increased impervious cover and, therefore, increased high and low flows.

The low-flow trend results for regulated gaging stations indicate that most of the gaging stations had an upward trend, and the significant trend results indicate that most of the gaging stations had upward trends. The results indicate a relation between regulated gaging stations and upward trends. Most of the low-flow trends for the unregulated gaging stations were downward, and most of the significant results were downward trends for the 7- and 30-day low flows. Significant results were evenly split for the 1-day low flows. In addition, the results might indicate a relation between downward flow trends and unregulated gaging stations and development, but the trend results for the undeveloped sites also were downward. This downward trend could indicate that there are other variables affecting the trends for the unregulated gaging stations. The relation of development to low-flow trends does not appear to be as strong as development to high-flow trends. The winter trend results for both high and low flows for each gaging station, in general, were similar to the trend results based on the annual data.

The trends results for two streamflow-gaging stations representing an undeveloped site and a drainage area undergoing development were compared to better assess the overall results of the trends analysis. Because both gaging stations are located in the same climate division, it was assumed that any trends in rainfall would have a similar effect on each gaging station. The two gaging stations are Flat Brook near Flatbrookville (01440000) (fig. 1), which is considered to represent an undeveloped, unregulated gaging station in northern New Jersey, and Rockaway River above Reservoir at Boonton (01380500) (fig. 1) in northern New Jersey, which is considered in the trend analysis to be an unregulated gaging station with development. Although the watershed is only 30-percent developed, the development has occurred throughout the period of record. In addition, the volume of ground-water withdrawals in the Rockaway River Basin has increased considerably over the period of record along with the amount of wastewater generated in the basin but discharged downstream from the gaging station. The trends for these two gaging stations for the 1-day high flow and 7-day low flow are illustrated in figure 14. The station at Flat
Brook near Flatbrookville had no significant results for low or high flows, although the trend was downward for all low flows and upward for all high flows. The station at Rockaway River above Reservoir at Boonton had a significant upward trend for the 1-day high flow and upward trends for the 7- and 30-day high flows. The low-flow trend results were downward for the 1- and 7-day low flows and upward for the 30-day low flow. No significant results were obtained for low-flow trends. Although this comparison is limited, it indicates a relation between development and high-flow trends and no strong relation between development and low-flow trends.

A greater number of significant trend results were expected for gaging stations with land-use changes during their period of record than were obtained. A number of variables directly affect streamflow and probably affected the results of the analysis. Some of these variables are precipitation trends, land-use changes, water-diversion trends, location of withdrawals, wastewater-discharge trends, location of discharges, and the period of record for the streamflow-gaging station being analyzed.

Long-term trends in precipitation have an obvious effect on streamflow trends, but short-term events can greatly affect the analysis. Data for 138 gaging stations with different periods of record (10 to 83 years of record) were used in the analysis. As the record used in the analysis gets shorter, the effects of a short-term event, such as the drought of the 1960s (4 to 5 year drought) (Bauersfeld and others, 1988) or the sharp increase in annual rainfall in the 1970s (fig. 15), could be significant. For example, if a gaging station period of record started in 1960 and ended in 1980 (20 years), the record would probably show a significant upward trend in low and high flows no matter how much development occurred in the drainage area. A plot of the 10-year moving average for the 7-day low flow at 01396500 South Branch Raritan River near High Bridge, N.J., is shown in figure 16. A definite downward slope during the late 1960s and an upward slope through the mid- to late 1970s is seen.

The drainage basins upstream from some gaging stations in New Jersey have had a dramatic increase in population and water use over the years of gaging-station record. In some areas, a large percentage of the water supply is coming from a source outside the basin, and the resultant wastewater is discharged upstream from the gaging station. In this situation, the increase in wastewater discharged could counteract an increase in impervious cover (decrease in infiltration) and result in no trend or an upward trend for low flow, especially where the discharge is a large percentage of low flow (Saddle River at Lodi, 01391500, fig. 1). In addition, many watersheds in New Jersey have changed from agricultural land use to suburban land use with an actual increase in forested acreage. In the Raritan River Basin, an estimated 13 percent of the land use was forested in the early 1900s (Smock, 1897), whereas in 1996 forested land use was estimated to be 35 percent of the watershed (Reiser and O'Brien, 1998). Use of watershed rainfall-runoff model, done for this study, rather than a statistical analysis probably could produce a better evaluation of the 

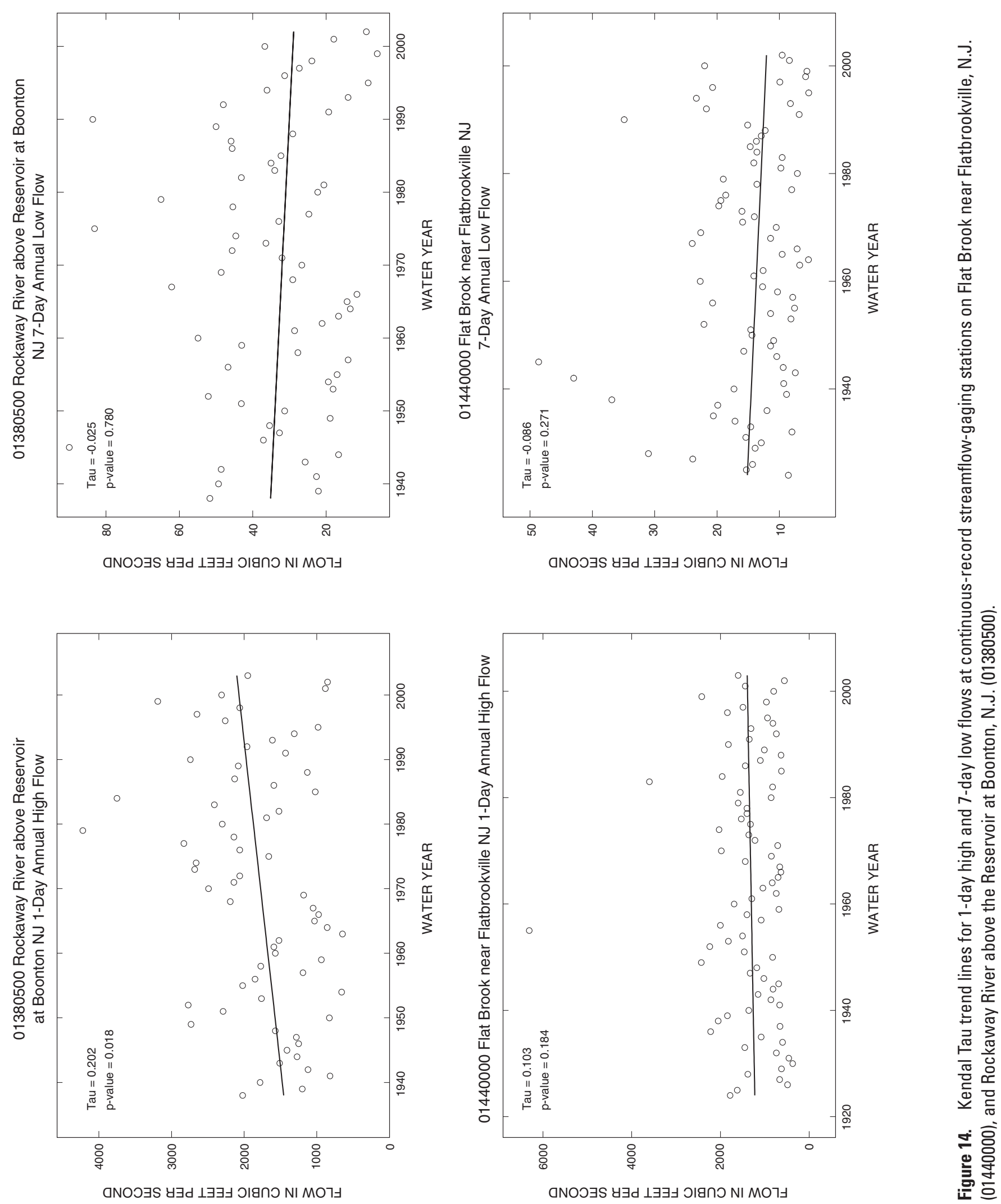
Total Annual Precipitation for New Jersey Climatic Division 1 1895-2001

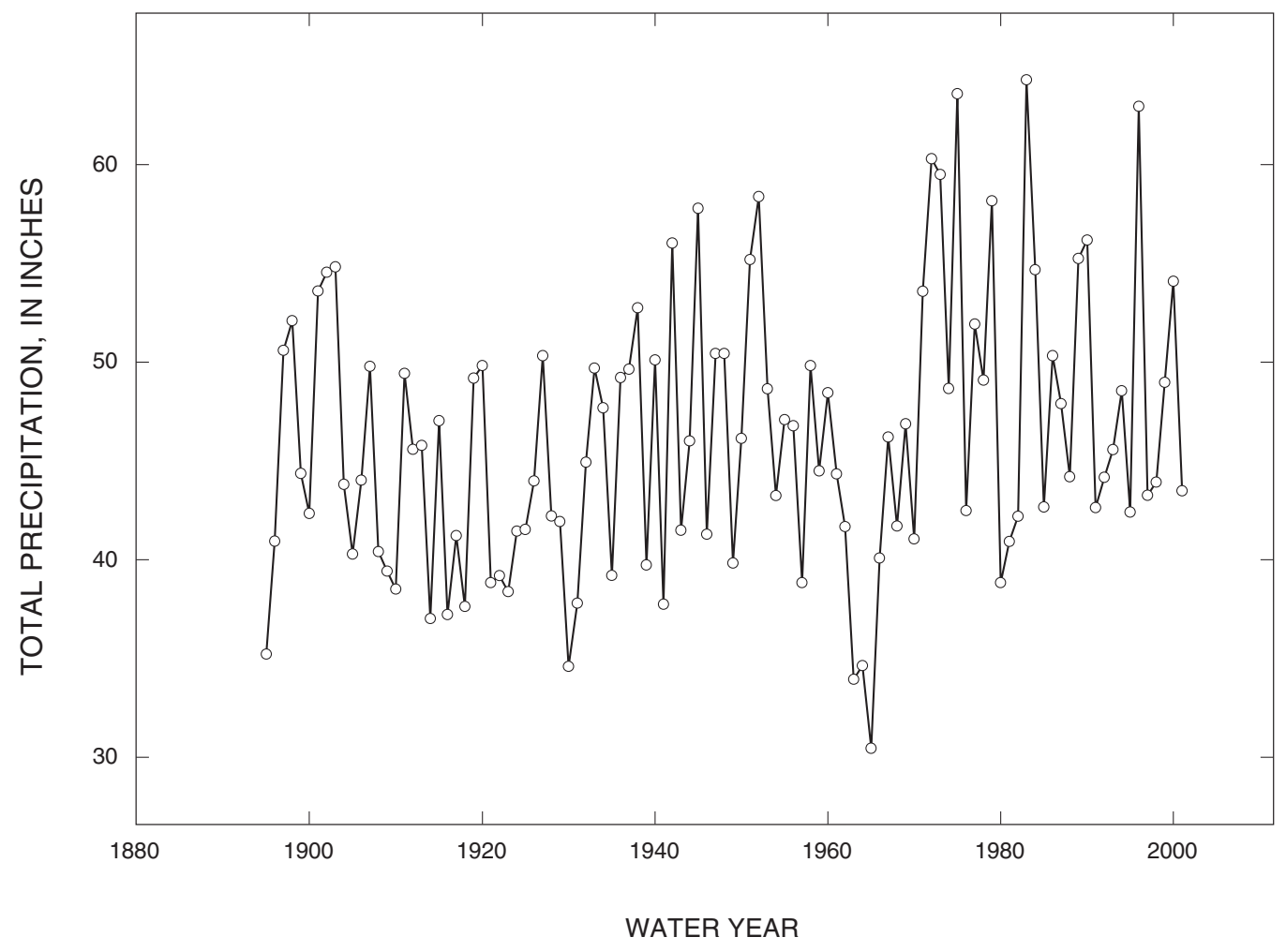

Total Annual Precipitation for New Jersey Climatic Division 2 1895-2001

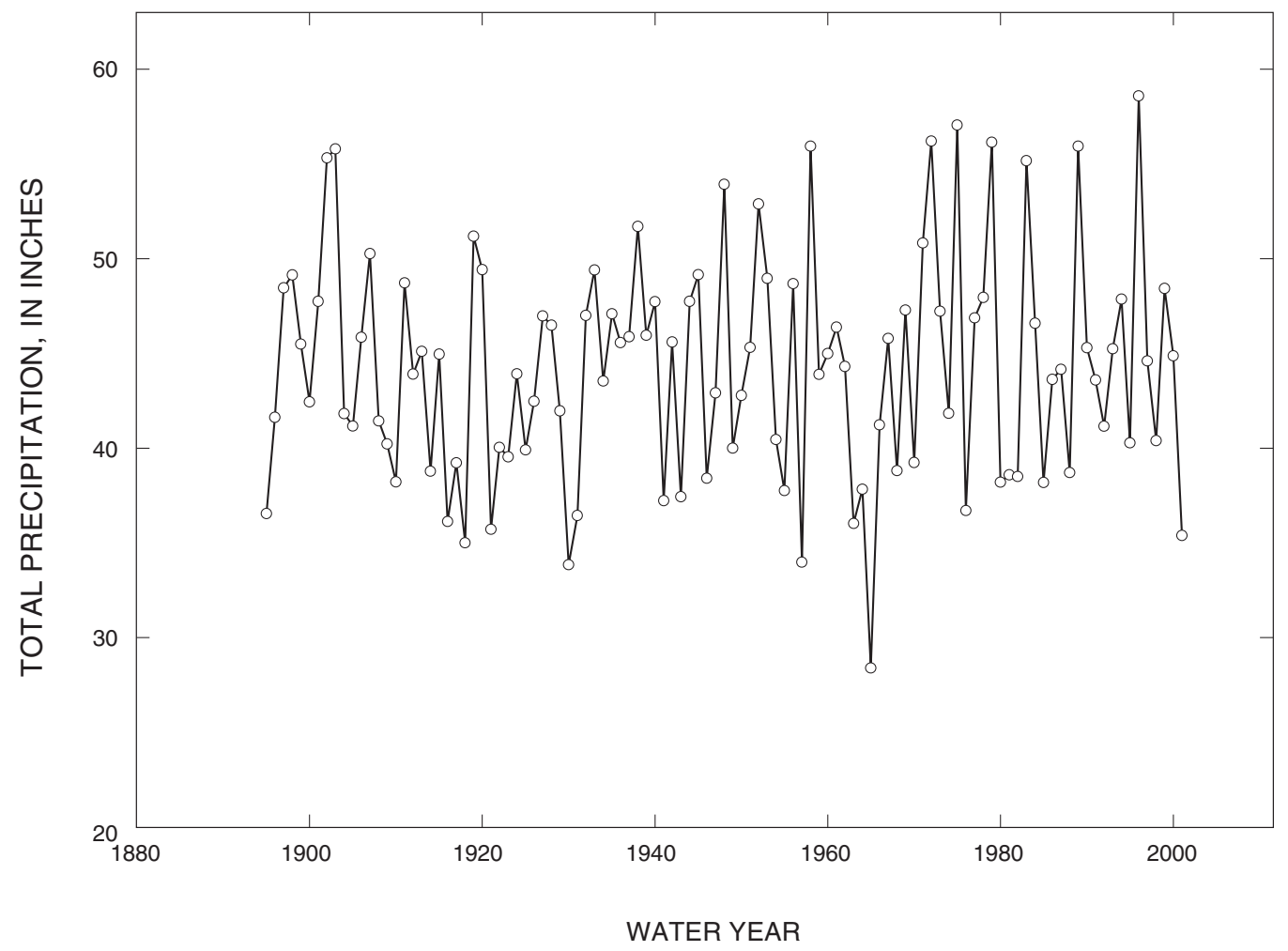

Figure 15. Total annual precipitation for New Jersey Climatic Divisions 1 and 2, water years 1895-2001. 


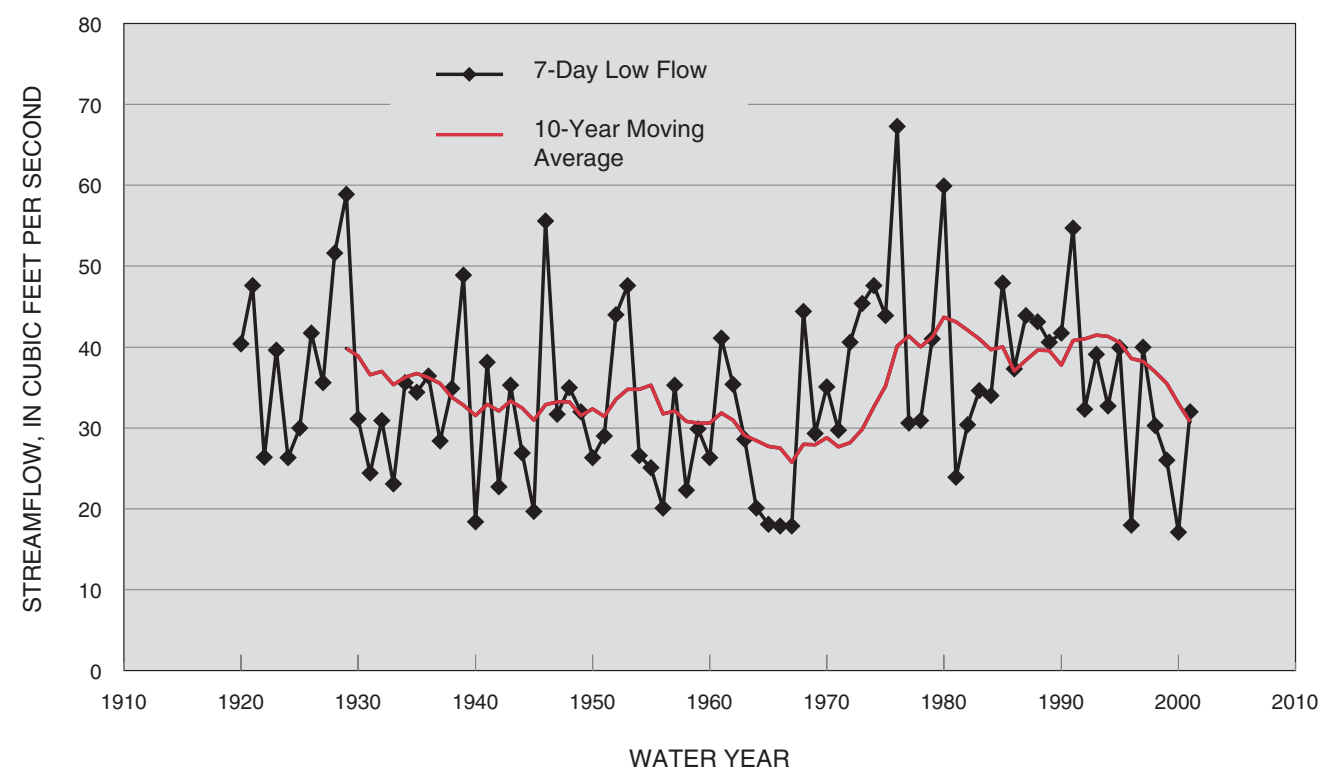

Figure 16. Annual 7-day low flow from water year 1919 through 2001 with a 10 -year moving average line for the continuous-record streamflow-gaging station South Branch Raritan River near High Bridge, N.J. (01396500). effects of land-use changes on streamflow trends. Even subtle land-use changes can affect flow trends. As stated previously, it is expected that suburban sprawl will decrease low flows and increase high flows because of greater withdrawals, more impervious cover, and larger stormwater systems. Since approximately the beginning of the 1980s, there has been a large increase in the use of detention/recharge basins to control storm runoff in housing developments in New Jersey. Such structures tend to modify streamflows and affect streamflow trends.

Stream regulation in a basin also can affect conditions in a watershed to various degrees. Increased wastewater discharges likely result in an upward trend for low and high flows as discussed above, whereas water-supply withdrawals likely result in a downward trend for low and high flows. Retention of water in a reservoir on a stream with a minimum passing flow could result in higher low flows but lower high flows by modifying peak runoff. The difficulty in analyzing the trend results is that many of these changes are occurring at different times and at varying rates in watersheds throughout New Jersey, and much of the data (long-term point-source discharge data, long-term withdrawal data, land-use data, and long-term streamflow data) needed to fully analyze flow trends are difficult to obtain or have not been collected.

\section{Comparison of Trends in Precipitation to Trends in Flow at Undeveloped Sites}

Precipitation trends can affect streamflow trends. An upward trend in precipitation likely results in an upward trend in high and low flows; the reverse likely results with a downward trend in precipitation. The season of the year along with an upward or downward precipitation trend may not affect the low or high streamflows. If the trend in precipitation is upward in winter and spring and downward in summer and fall, the result could be an upward trend for high flows but a downward trend for low flows. As presented in the streamflow trend analysis, short-term climate events (drought for 2-3 years or above average precipitation for 2-3 years) also can affect streamflow trends when one or both of these events constitute a large percentage of the gaging station record.

Monthly precipitation records for New Jersey Climate Divisions 1 and 2 and for eight individual rain gages in New Jersey were retrieved from the National Oceanic and Atmospheric Administration National Climatic Data Center (National Oceanic and Atmospheric Administration, 2000). Average annual precipitation values are given below. The longterm average annual precipitation for 1895 to 2001 in northern New Jersey Climate Division 1, which includes the Piedmont, New England, and Valley and Ridge Physiographic Provinces (fig. 4), is $46.1 \mathrm{in.}$ The average annual precipitation for 1895 to 2001 in southern New Jersey Climate Division 2, which includes the Coastal Plain and part of the Piedmont Physiographic Province (fig. 4), is 44.2 in.

\begin{tabular}{cccc}
\hline \multirow{2}{*}{$\begin{array}{c}\text { Climate division } \\
\text { (fig. 4) }\end{array}$} & \multicolumn{3}{c}{$\begin{array}{c}\text { Average annual precipitation, } \\
\text { in inches }\end{array}$} \\
\cline { 2 - 4 } & $\mathbf{1 8 9 5 - 2 0 0 1}$ & $\mathbf{1 8 9 5 - 1 9 7 0}$ & $\mathbf{1 9 7 1 - 2 0 0 1}$ \\
\hline 1 & 46.1 & 44.6 & 49.8 \\
2 & 44.2 & 43.7 & 45.6 \\
\hline
\end{tabular}

The Wilcoxon rank-sum nonparametric test was used to determine whether precipitation totals significantly differed from the 1895-1970 to the 1971-2001 periods. Total annual precipitation was significantly greater during the 1971-2001 
period than during the $1895-1970$ period in northern New Jersey (Climate Division 1). No significant difference was observed between the two periods in Climate Division 2. Total monthly precipitation also was compared between the two periods. The only significant difference found between the 1895-1970 and the 1971-2001 periods were greater precipitation in May in both Climate Divisions during 1971-2001 than during 1895-1970.

A Kendall Tau trend test was performed on the total annual (table 6) and total monthly precipitation data for Climate Divisions 1 and 2 and for each of the eight individual gages. Trend tests also were run on total precipitation during the growing season and during the non-growing season at the individual rain gages. Data for the period of precipitation that most closely matched the nearby gaging-station record were used for trend analysis. Significant upward trends were detected for total annual precipitation and total monthly precipitation for May and November during 1895-2001 in Climate Division 1 in northern New Jersey. The only significant trend in the precipitation data for Climate Division 2 was a downward trend in February during 1895-2001. Of the eight rain gages, the Wertsville gage (fig. 17) in Climate Division 1 had the highest number of significant trends. A significant increase was observed in annual, growing season, non-growing season, and monthly totals from January through March, May, and September during 1956-2001. Upward trends for annual precipitation were observed for the Boonton gage (fig. 17). October precipitation significantly increased during 1938-97 at the Boonton gage. No trends were observed in precipitation data for the Newton, Long Valley, Ringwood, and Long Branch gages. Precipitation in January and May significantly increased at the Pemberton gage during 1954-2001. June precipitation significantly decreased at the Indian Mills gage.

Precipitation data were compared to the trend results for the gaging stations in undeveloped sites (less than 15 percent developed). There are 4 gaging stations at undeveloped sites in Climate Division 1 and 10 in Climate Division 2 (table 2).

Table 6. Results from Kendall Tau trend analysis for total annual precipitation at selected sites in New Jersey.

\begin{tabular}{llrrl}
\hline \multicolumn{1}{c}{ Rain gage } & $\begin{array}{c}\text { Period of } \\
\text { record }\end{array}$ & Tau & p-value & Trend \\
\hline Boonton & $1926-97$ & 0.2074 & 0.010 & Upward \\
Indian Mills & $1926-2001$ & -.0561 & .473 & None \\
Long Branch & $1928-2001$ & .0026 & .974 & None \\
Long Valley & $1931-2001$ & .0535 & .509 & None \\
Newton & $1949-2001$ & .0639 & .500 & None \\
& & & & \\
Pemberton & $1949-2001$ & .0464 & .624 & None \\
Ringwood & $1949-2001$ & -.0145 & .878 & None \\
Wertsville & $1957-2001$ & .3212 & .002 & Upward \\
Climatic Division 1 & $1895-2001$ & .1469 & .025 & Upward \\
Climatic Division 2 & $1895-2001$ & .0180 & .784 & None \\
\hline
\end{tabular}

Overall, for the undeveloped sites, 11 of 14 gaging stations had downward trends for two or more low flows, and 8 of 14 gaging stations had upward trends for high flows. In Climate Division 1, two gaging stations had significant downward trends for at least one low flow, and one gaging station had a significant upward trend for one high flow. In Climate Division 2, one gaging station had a significant downward trend for at least one low flow. Although average rainfall in each Climate Division has increased between the period of 18951970 and 1971-2001 and Climate Division 1 had a significant upward trend for annual data, results of trend tests indicate downward low-flow trends for the undeveloped sites, which is contrary to the precipitation results.

Trend analysis was run on precipitation data for the five rain gages in Climate Division 1-Boonton, Ringwood, Newton, Wertsville, and Long Valley - and the three in Climate Division 2-Indian Mills, Long Branch, and Pemberton-to compare to streamflow trend data for gaging stations in undeveloped basins. Results of analysis indicated significant upward trends in precipitation at two of the rain gages, Boonton and Wertsville (fig. 4). No significant downward trends were determined at any rain gage. Significant downward trend results were determined for the 7- and 30-day low flows for Green Pond Brook at Picatinny Arsenal (01379773) (fig. 4), which is in the same drainage basin as the Boonton rain gage. Significant downward trends were observed for the 1-, 7-, and 30-day low flows at Blue Mine Brook near Wanaque (01386500) (fig. 4), and a significant upward trend was determined for the 7-day high flow. This gaging station is near the Ringwood rain gage, which did not have a significant precipitation trend. No significant trends were determined for Ringwood Creek near Wanaque (01384500) (fig. 4), but low flows decreased for each flow regime, and the high flow trend increased for the 7- and 30-day flow but decreased for the 1-day flow. A significant downward trend resulted for the 1-, 7-, and 30-day low flows at the gaging station at McDonalds Branch in Lebanon State Forest (01466500) (fig. 4) in Climate Division 2; no significant annual trends resulted for the precipitation gages Pemberton and Indian Mills in the same general area. A significant downward trend for June resulted for the Indian Mills rain gage, which could indicate the cause of the downward low-flow trends at the McDonalds Branch streamflow-gaging station.

The results of the comparison of the precipitation trend with the trend for streamflow in undeveloped basins, although limited, indicate that variables other than precipitation affect low flows in the State. Only one undeveloped site had significant upward high-flow trends, and the trends are nearly evenly split between upward and downward for other undeveloped sites for high flows. A general increase has occurred in average precipitation in Climate Division 2, and a significant increase has occurred in Climate Division 1. This result indicates that high flows from undeveloped, unregulated sites have not been affected by the increase in average precipitation and that the upward high-flow trends for the regulated and unregulated gaging stations are associated with increased development. 


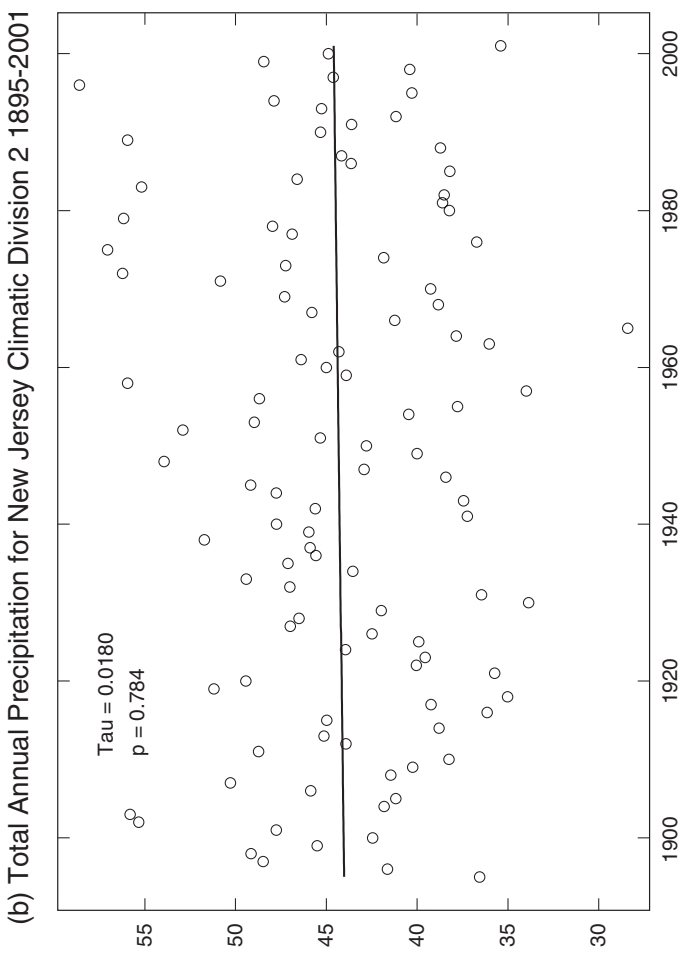

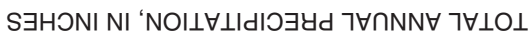

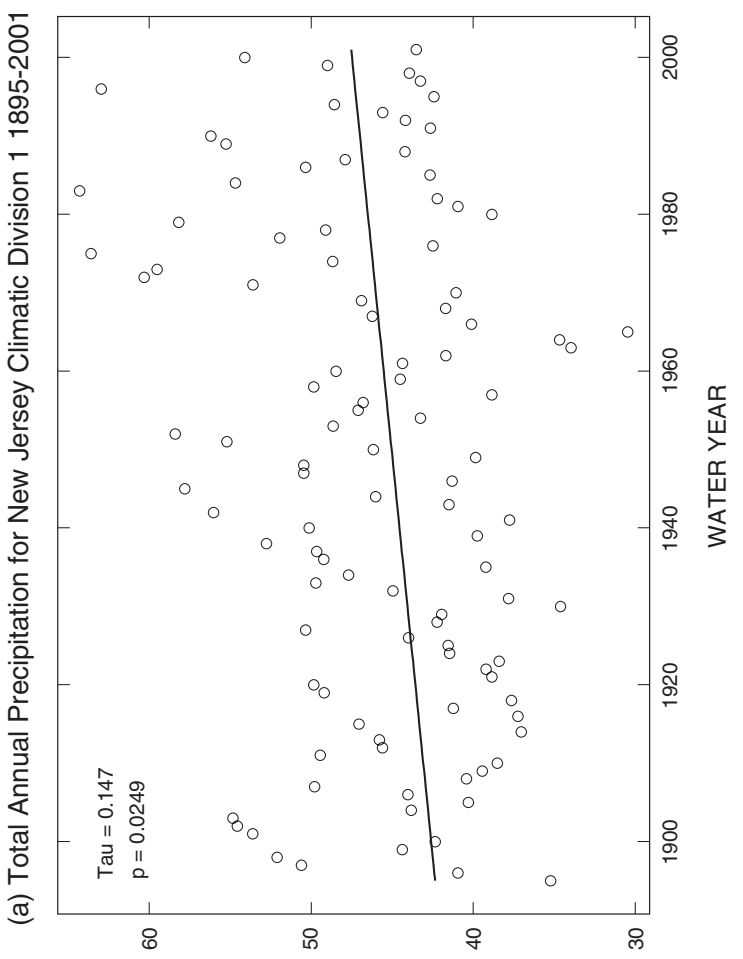

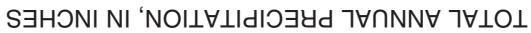

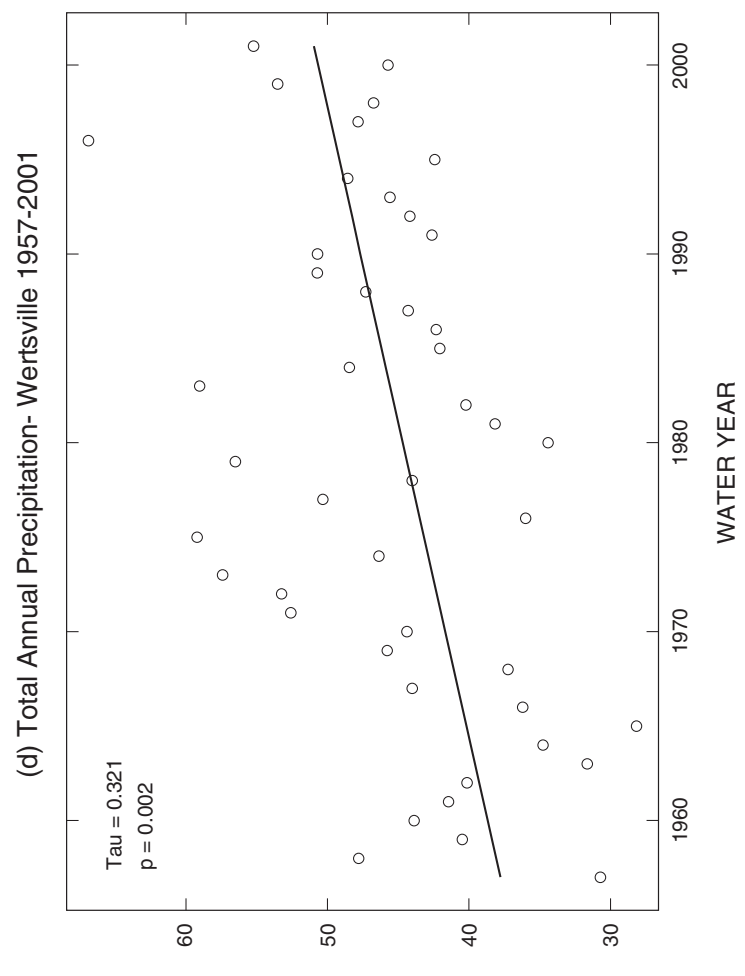

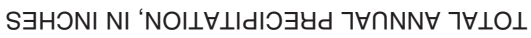

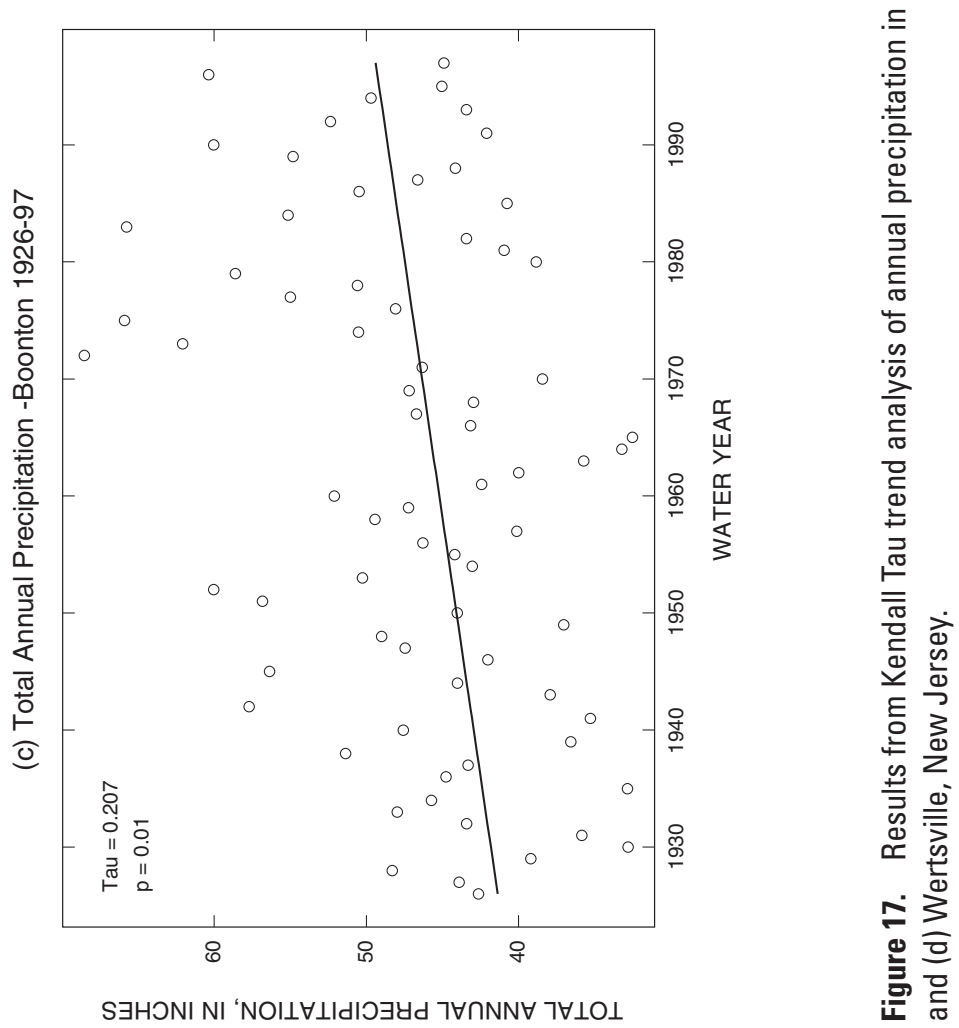




\section{Trends in Peak Ratio at Selected Streamflow-Gaging Stations}

Peak-ratio trend analysis was run on streamflow data for 28 gaging stations. These stations were chosen as representative of various levels of development and regulation throughout the State. Many of the gaging stations in regulated and unregulated areas have had substantial changes in land use and water use over the past 20 to 40 years. All gaging stations that were used in this analysis have minimal regulation at high flow and are considered appropriate for high-flow analysis.

The peak ratio is determined from annual peak flow, which is the value of the maximum instantaneous streamflow occurring in the water year divided by the 3-day mean flow for 3 consecutive days, including the days before, during, and after the peak. Peak ratio is a measure of the magnitude of the rise and fall of a stream over a given period of time. The peak ratio can be used as a method to define the flashiness of a stream. The higher the value, the greater the flashiness of the stream. The peak-ratio trend was determined for selected gaging stations using the Kendall's Tau test (Helsel and Hirsch, 2002). The test determines the probability that the null hypothesis of no significant trend can be rejected with a low risk of error. A $p$-value equal to 0.05 indicates there is a 95 -percent chance that a trend is present.

Kendall's Tau trend test was used to analyze whether increased development and urbanization of New Jersey basins was increasing the variability/flashiness of streams. As presented in the discussion on streamflow trends, there are some basins in New Jersey that have not had an appreciable increase in suburban sprawl over the last 20 to 30 years. Some of this sprawl has resulted in a decrease in forested lands, whereas some has resulted in a decrease in farmland. In some areas, forested land has increased along with an increase in suburban sprawl and a decrease in agricultural land.

The results of the analysis show that six gaging stations had significant upward trends (table 7). Five of the six gaging stations are located in northern New Jersey in the New England and Piedmont Physiographic Provinces. Three gaging stations had a significant downward trend. Two are located in the Atlantic Coastal Plain, and the other one in the New England Physiographic Province. The remaining 19 gaging stations had no significant peak-ratio trend. These gaging stations are distributed fairly evenly throughout the State (fig. 18).

Land use was determined for areas upstream from the 28 gaging stations. Results of peak-ratio trends at gaging stations are listed in table 7 in descending order of the percentage of land considered developed. A total of 17 gaging stations had positive Kendal Tau values, indicating a general upward trend, whereas 11 had negative Kendal Tau values, indicating downward trends. All six gaging stations with significant upward trends have greater than 30-percent developed land use with a large percentage of the developed land designated urban land use. Three gaging stations had significant downward trends; one has greater than 30-percent developed land use, and the other two have 21-percent and 17-percent developed land use. Gaging stations at three undeveloped sites were included in the analysis; no significant trends were observed at these sites. Although the increase in average precipitation and the upward precipitation trend in Climate Division 1 could be the cause of the upward trends in peak ratio, the peak-ratio trend results indicate that there is a relation between an increase in peak ratio and developed land use.

\section{Estimates of Low-Flow Statistics at Ungaged Sites}

The USGS receives many requests for low-flow statistics for stream sites that lack streamflow data, for example, points upstream from the outfall of permitted point-source discharges and surface-water intakes. The statistics are requested by Federal, State, and local agencies and by private consultants. The New Jersey Water Science Center has developed procedures for estimating low-flow statistics at these locations. Statistics, such as the 7-day 10-year low flow (7Q10), 1-day 10-year low flow, 30-day 10-year low flow for both the summer and winter periods, harmonic mean, mean annual flow, and flow durations (the flow that was exceeded for an indicated percentage of time less than or equal to the median flow), are the most commonly requested data. Long-term continuous records of daily streamflow at gaging stations and base-flow discharge measurements at low-flow sites are the data on which estimates of low-flow statistics at sites with no streamflow data-ungaged sites-are based.

An accurate location of the ungaged site is needed to provide the best estimate of streamflow. The location of tributaries, reservoir releases, surface-water withdrawals, point-source discharges, and well fields affects the low flow along a stream. The estimate of a low-flow statistic can vary substantially for a location upstream and a location downstream from these features.

Accuracy of the low-flow estimates at ungaged sites is a function of the sum of errors inherent in the collection and computation of streamflow data, the statistical methods used to compute the statistics at the gaging stations and low-flow sites, and the error involved in transferring those statistics to another stream site. These errors include discharge-measurement errors at the index site and at the low-flow sites ( \pm 5 percent), errors in the computation of the daily mean flows at the index site, the standard error of prediction of the MOVE1 correlation between daily mean flows at the index site, and instantaneous measurements of flow at the low-flow sites. For these reasons, the estimates of flow are rounded to the nearest $0.1 \mathrm{ft}^{3} / \mathrm{s}$. 


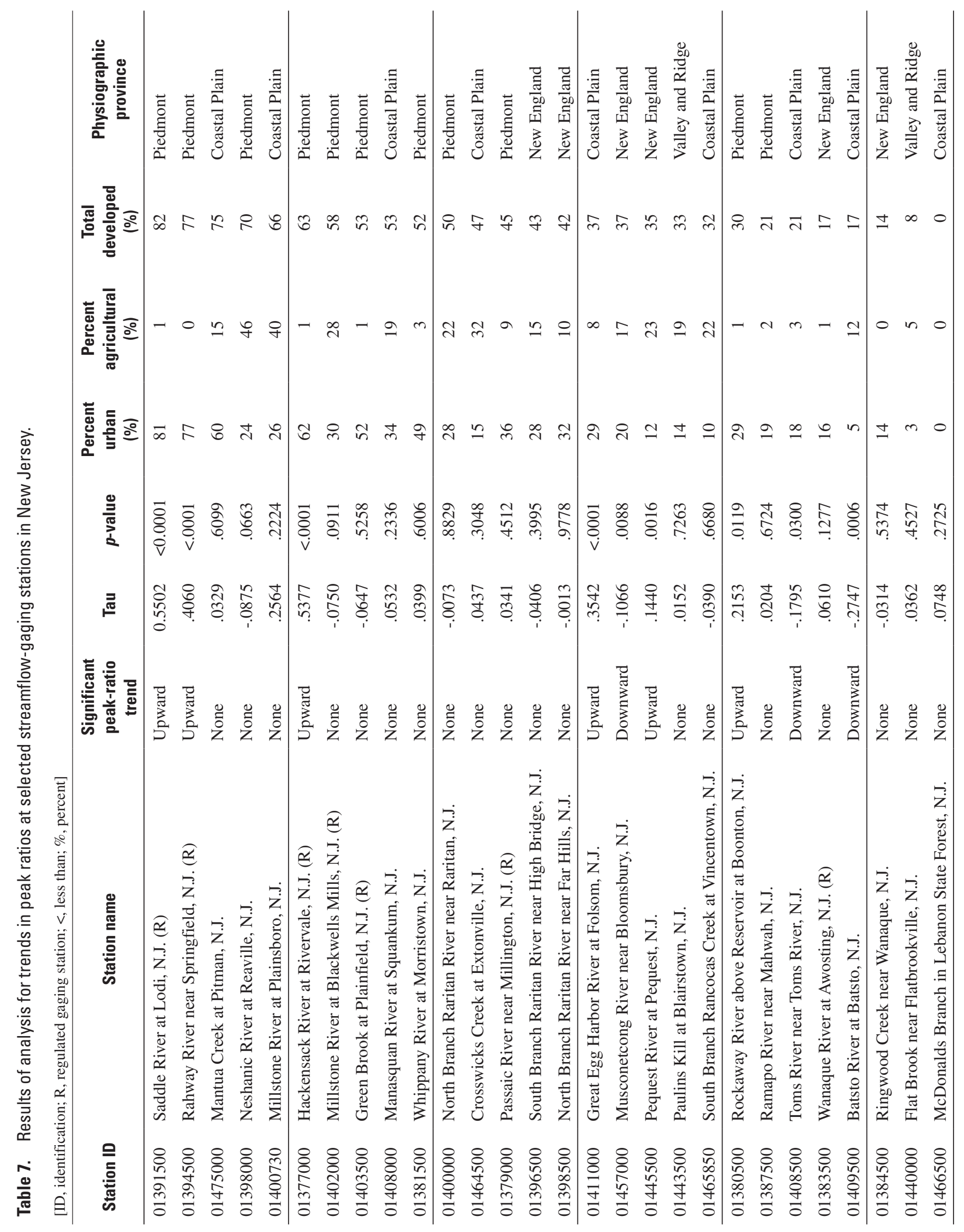




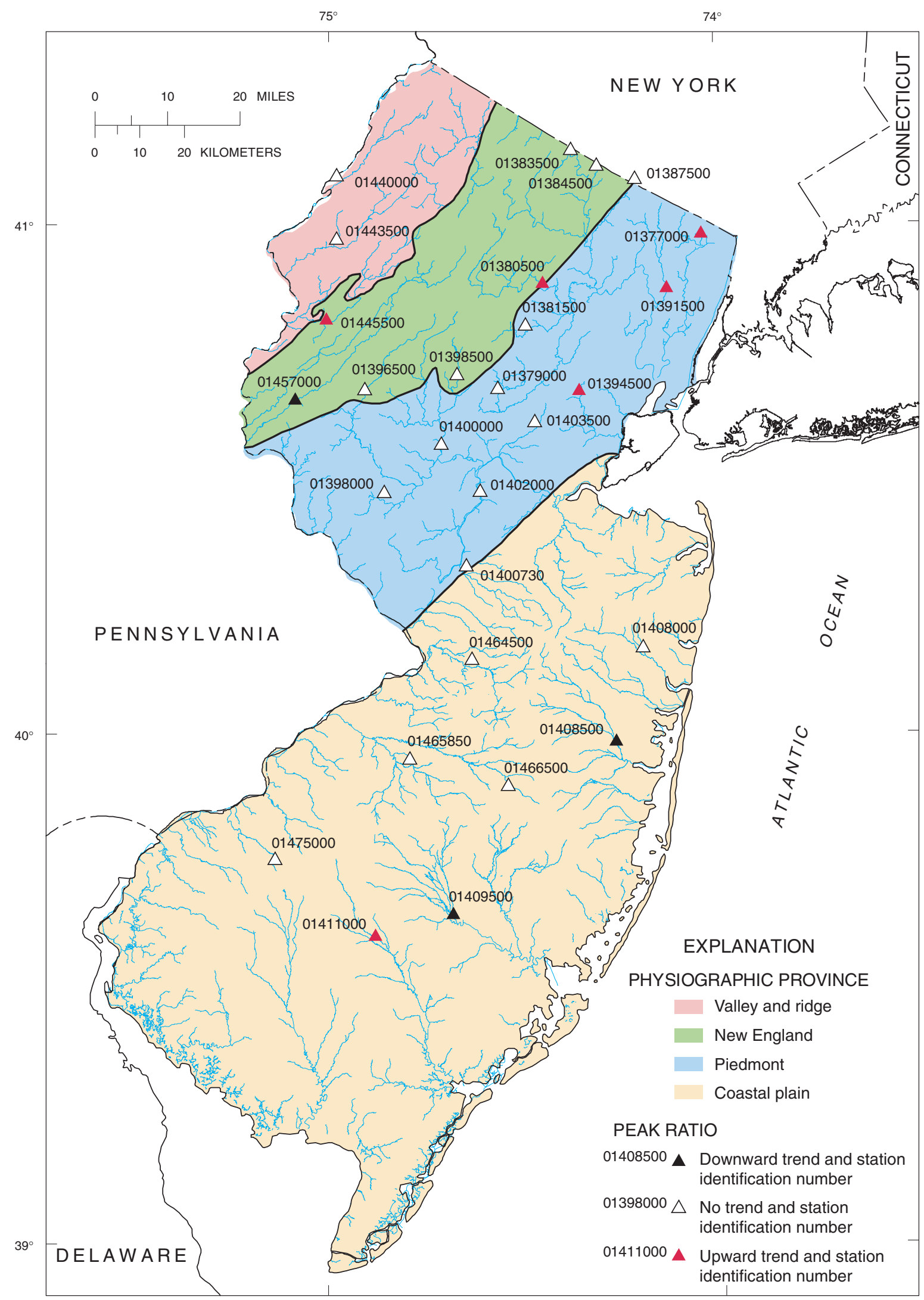

Base from U.S. Geological Survey digital line graph files, 1:24,000 North American Datum 1983, UTM, Zone 18N

Figure 18. Results of peak-ratio trend analysis, by physiographic province, in New Jersey. 


\section{Ungaged Sites on Streams with Streamflow Data and No Regulation}

Streamflow data from gaged sites located along the same stream as the ungaged site are the best sources of information on which to base an estimate of a low-flow statistic when no point-source discharges, diversions, or withdrawals occur between the sites. Drainage area is an essential factor used to transfer low-flow statistics from a gaged site to an ungaged site along a stream reach. The location of the ungaged site is used to calculate the drainage area upstream from the site. If the ungaged site is upstream or downstream from a gaging station or low-flow site on an unregulated stream, then a drainage-area ratio is used to transfer the low-flow data at the gaged site to the ungaged site. The flow contributed per unit area upstream from the gaged site is presumed to be same for the ungaged site.

The stream reach along the South Branch Raritan River from the low-flow site at Middle Valley (01396280) (fig. 19) downstream to the gaging station at High Bridge (01396500) (fig. 19) does not receive any discharge from point sources or lose any flow to withdrawals. In the previous section, data from these sites were used to demonstrate the MOVE1 correlation method of transferring statistics from a gaging station to a low-flow site. The drainage-area ratio method also can be used to transfer low-flow statistics from the gaging station to the site at Middle Valley. For the purpose of this example, the South Branch Raritan River at Middle Valley is treated as an ungaged site. In this example, the 7Q10 low flow is transferred from the gaging station at High Bridge to a low-flow site upstream on the South Branch Raritan River at Middle Valley. Estimates from the drainage-area ratio and the MOVE1 correlation technique are compared.

7Q10 flow is transferred from gaging station 01396500 South Branch Raritan River at High Bridge to a site upstream, 01396280 South Branch Raritan River at Middle Valley. The drainage area at gaging station 01396500 is $65.3 \mathrm{mi}^{2}$. The drainage area at the site at Middle Valley is $47.7 \mathrm{mi}^{2}$. The 7Q10 flow for gaging station 01396500 is $22.0 \mathrm{ft}^{3} / \mathrm{s}$. The $7 \mathrm{Q} 10$ flow for station 01396280 is to be determined.

(1) Determine the drainage area $(D A)$ ratio (no limits on the $D A$ were used):

$$
D A_{\text {ungaged }} / D A_{\text {gage }}=47.7 / 65.3=0.73
$$

(2) Multiply the calculated ratio by the low-flow statistic for the gaging station:

$$
0.73 \times 22.0 \mathrm{ft}^{3} / \mathrm{s}=16.5 \mathrm{ft}^{3} / \mathrm{s} \text { (7Q10 flow) }
$$

The MOVE1 correlation analysis between the base-flow measurements at South Branch Raritan River at Middle Valley (01396280) and daily mean flows at gaging station 01396500 predicts a 7Q10 low flow of $14.1 \mathrm{ft}^{3} / \mathrm{s}$ at 01396280 (fig. 8). The flow estimated from drainage-area adjustment is about 17 percent higher than the flow computed from the MOVE1 analysis. This example shows the difference between the estimate of 7Q10 low flow at a low-flow site using base-flow measurements and the estimate for the same site when no streamflow data are available. If no base-flow measurements had been made at the site, the result from the drainagearea ratio method would be used. Base-flow measurements allow for a more accurate estimate of 7Q10 low flow. Periods of base flow at the gaging station at High Bridge can be related directly to the base-flow measurements at the site at Middle Valley.

\section{Ungaged Sites on Streams with Streamflow Data and Regulation}

Surface-water withdrawals and point-source discharges are important factors to consider when transferring streamflow statistics from one site to another along a stream reach. When low-flow statistics are requested for a site downstream from a known withdrawal or point source, it is most effective to use data that reflect these human alterations. The drainage-area ratio method is not used to transfer the low-flow data from the gaged site to the ungaged site along a regulated stream reach. The Hackensack River Basin is an example of a highly regulated basin with streamflow-gaging stations and low-flow sites within the basin.

The streamflow in the Hackensack River downstream from the Oradell Reservoir is regulated by the DeForest Lake, Lake Tappan, Woodcliff Lake, and Oradell Reservoir (fig. 20). Water is diverted from Oradell Reservoir, DeForest Lake, and Hackensack River at West Nyack, New York, for municipal supply. Gaging stations on the Hackensack River at West Nyack, New York (01376800), at Rivervale, New Jersey (01377000), at New Milford, New Jersey (01378500), and Pascack Brook at Westwood, New Jersey (01377500) (fig. 20) record streamflows in the basin.

This following example shows the procedure for estimating the 7Q10 low flow at an ungaged site on the Hackensack River at Hackensack (fig. 21). The gaging station on the Hackensack River at New Milford (01378500) (fig. 21) is the most downstream streamflow-gaging station in the basin. This station records the flow in the Hackensack River downstream from all withdrawals and diversions. The Hackensack River between the gaging station and the city of Hackensack receives water from the regulated releases on the river and 


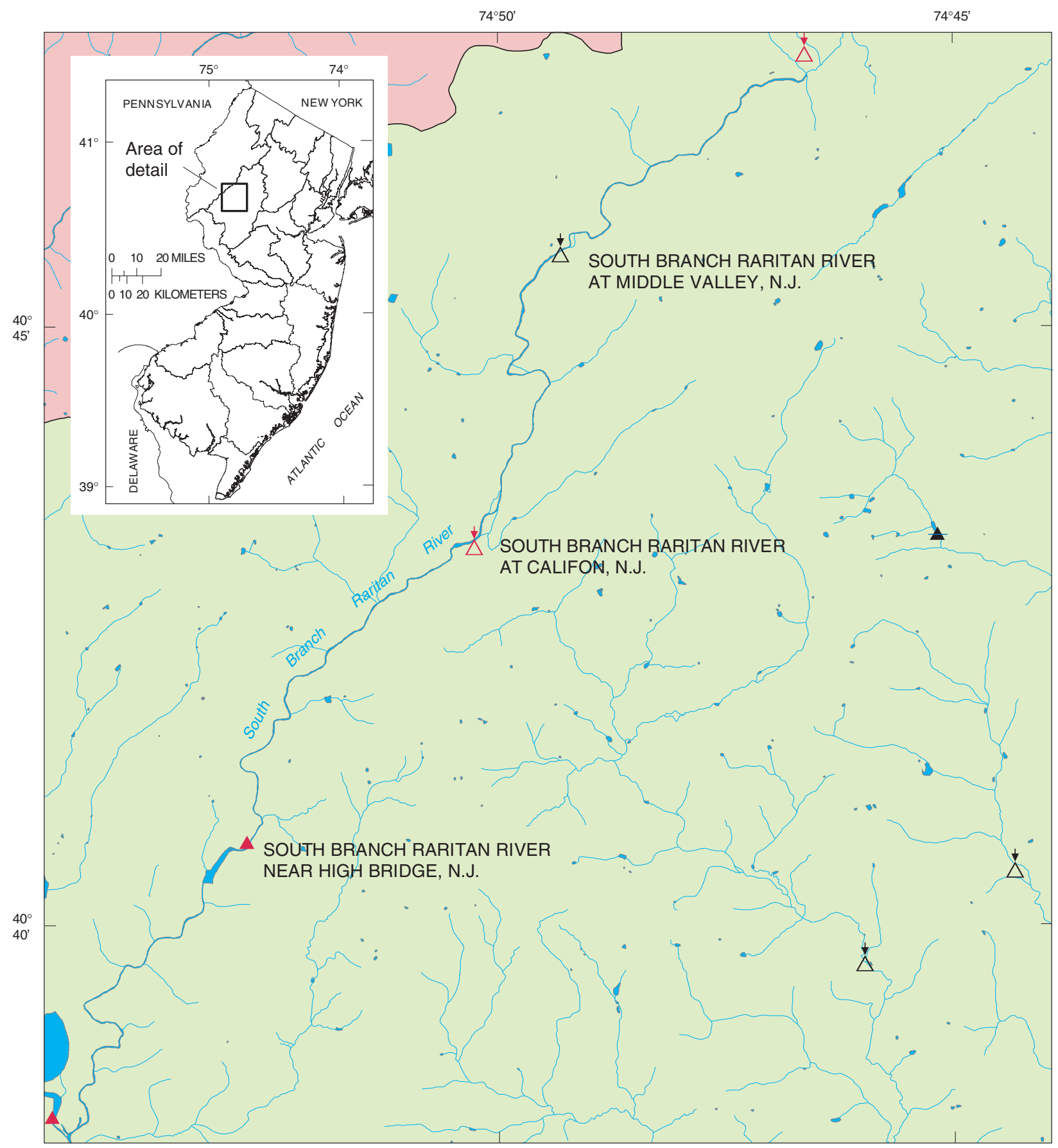

Base from U.S. Geological Survey digital line graph files, 1:24,000

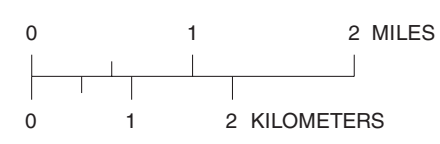

EXPLANATION

WATERSHED MANAGEMENT AREAS CONTINUOUS-RECORD STREAMFLOWGAGING STATIONS
- Active
- Inactive

LOW-FLOW PARTIAL-RECORD STATIONS

$\triangle$ Active

$\triangle$ Inactive

Figure 19. Location of continuous-record streamflow-gaging stations and low-flow partial-record stations in the North and South Branch Raritan Watershed Management Area (WMA) in New Jersey. 


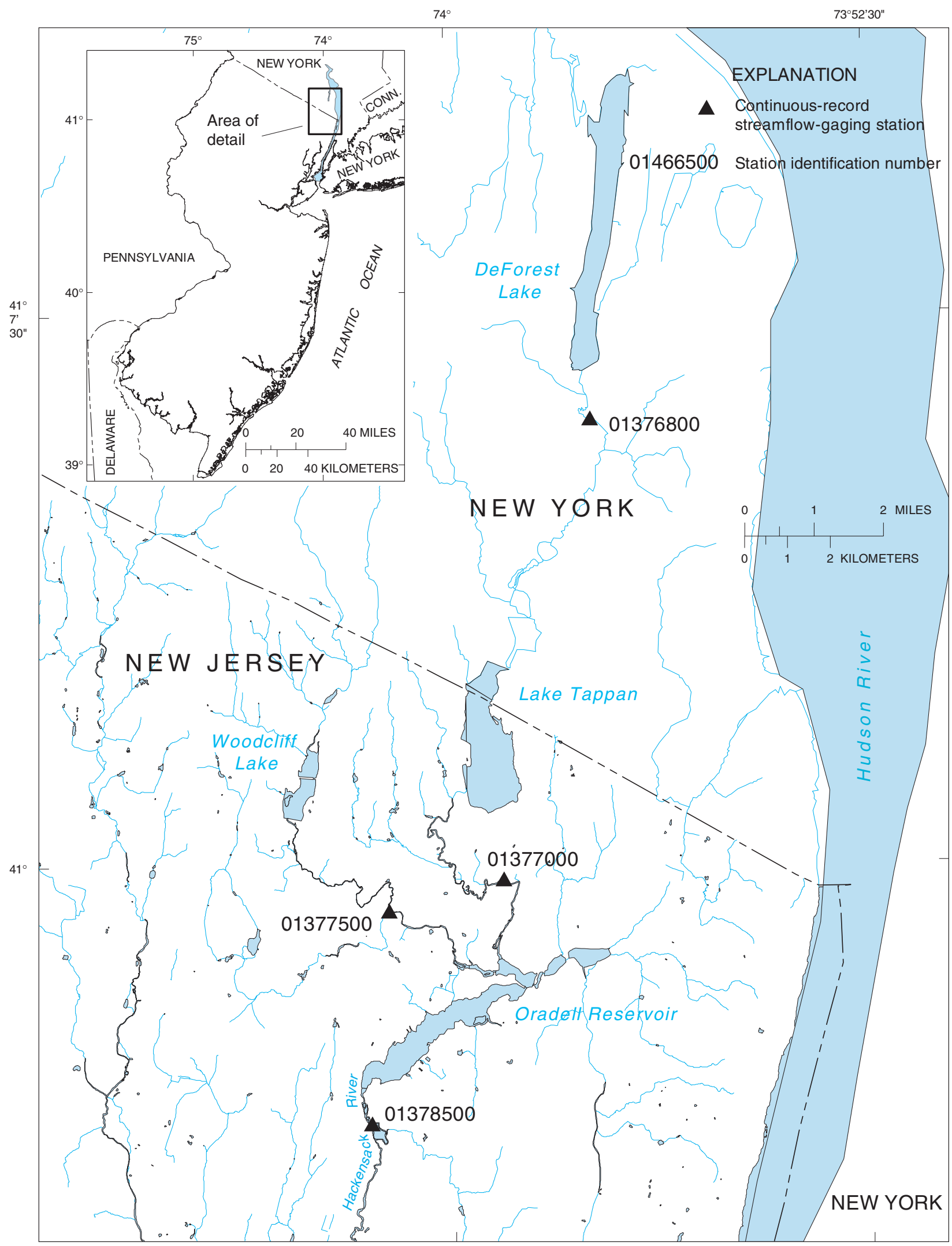

Base from U.S. Geological Survey

digital line graph files, 1:24,000

Figure 20. Location of lakes, reservoirs, and selected streamflow-gaging stations upstream from the Hackensack River in New Jersey and vicinity. 


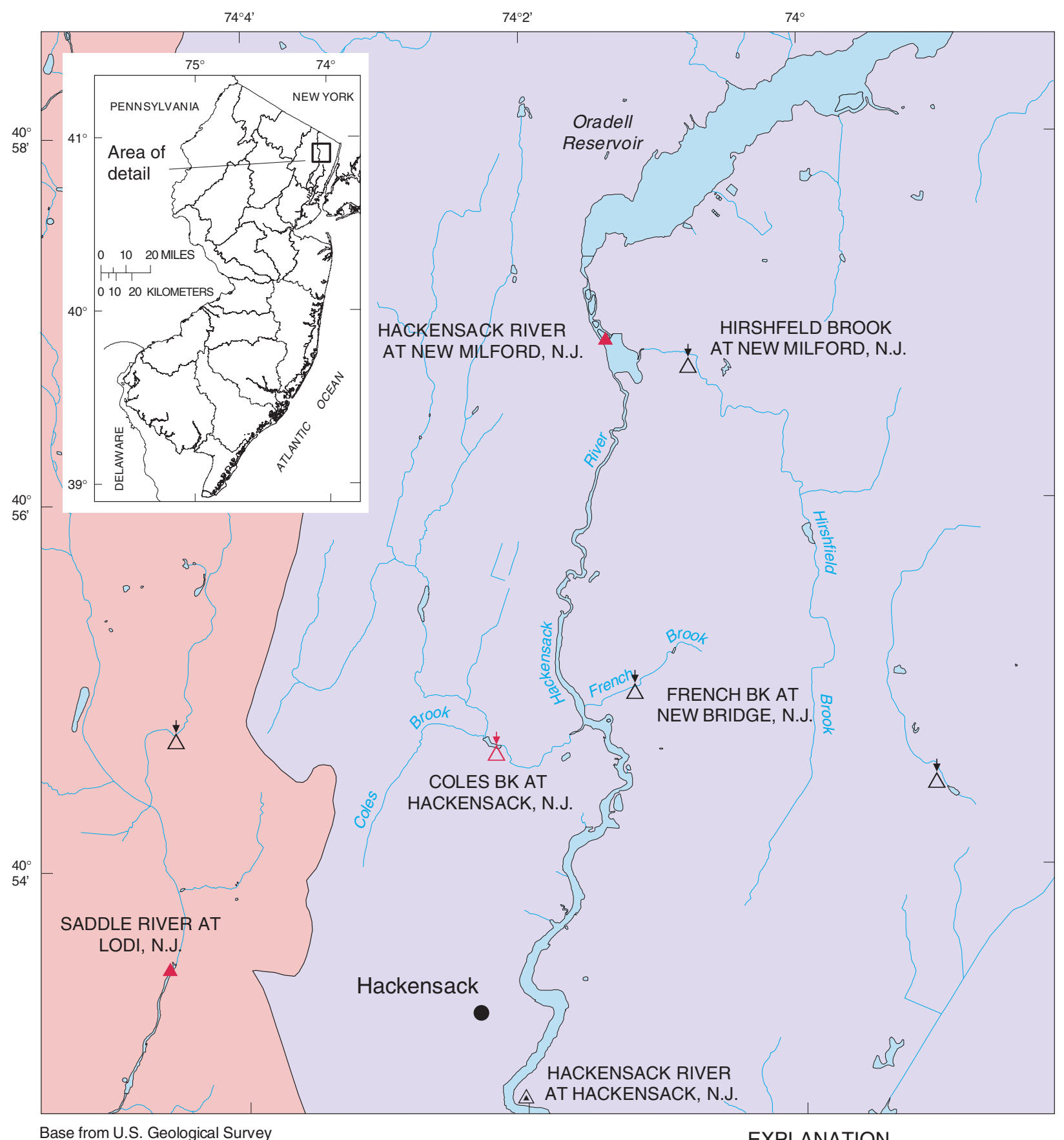

Base from U.S. Geological Survey digital line graph files, 1:24,000

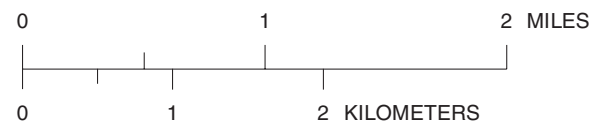

Figure 21. Locations of continuous-record streamflow-gaging stations, low-flow partial-record stations, and an ungaged site in the Hackensack and Pascack and the Lower Passaic and Saddle Watershed Management Areas, New Jersey. 
from various tributaries that drain to the river. The drainagearea method cannot be used to accurately transfer the low-flow statistics from the gaging station to the site on the Hackensack River at Hackensack because the intervening area receives streamflow from unregulated sources.

The drainage area at the point of interest along the Hackensack River at Hackensack is essential information for analysis. The drainage area delineated for the ungaged site is $131 \mathrm{mi}^{2}$. The drainage area at the gaging station is $113 \mathrm{mi}^{2}$. The 7Q10 flow at the gaging stations is known. The 7Q10 flow for the $18 \mathrm{mi}^{2}$ intervening area is unknown and will be estimated from data on unregulated low-flow sites in the area.

Three major tributaries with drainage areas greater than $0.5 \mathrm{mi}^{2}$ in size-Coles Brook, French Brook and Hirshfeld Brook-drain into the Hackensack River along the reach (fig. 21). A low-flow site is present on each of the three major tributaries. The MOVE1 correlation analysis, as explained in the section on low-flow sites, is used to compute the 7Q10 flow at each of these sites. The 7Q10 flow from the gaging station and the three low-flow sites were added together. The drainage areas at the gaging station in New Milford (01378500) (fig. 21) and at the three low-flow sites also were added together. The drainage areas at these sites total $125 \mathrm{mi}^{2}$, which is subtracted from the total drainage area at the Hackensack River at Hackensack. The remaining $6.00 \mathrm{mi}^{2}$ is the intervening area that contributes an unknown amount of flow to the Hackensack River. The flow estimated at the low-flow sites is representative of flow from this intervening area. The 7Q10 flow at each low-flow site is divided by the drainage area to give a flow per square mile value. The average 7Q10 flow per square mile for the three low-flow sites is used to estimate the contribution from the intervening area. In this case, the average 7Q10 flow per square mile is $0.145 \mathrm{ft}^{3} / \mathrm{s}$.

The total 7Q10 flow, in cubic feet per second, at the Hackensack River at Hackensack, New Jersey, is the sum of the following computed and estimated 7Q10 flows:

New Milford $\left(0.0 \mathrm{ft}^{3} / \mathrm{s}\right)+$ Coles Brook $\left(0.92 \mathrm{ft}^{3} / \mathrm{s}\right)+$ French Brook at mouth $\left(0.07 \mathrm{ft}^{3} / \mathrm{s}\right)+$

Hirschfeld Brook at mouth $\left(0.83 \mathrm{ft}^{3} / \mathrm{s}\right)+$ intervening area $\left(0.145 \mathrm{ft}^{3} / \mathrm{s} / \mathrm{mi}^{2} \times 6.0 \mathrm{mi}^{2}\right)=2.7 \mathrm{ft}^{3} / \mathrm{s}$

\section{Ungaged Sites on Streams with No Streamflow Data and No Regulation}

If no streamflow data are available for the stream on which the ungaged site is located, averages of the flow per square mile at three to six nearby gaging stations or partialrecord stations are used to estimate flows at the site of interest. No limits were set on distance from site, physiographic area, or drainage area. A map of gaging stations and partial-record stations in the area is used to locate the sites closest to the ungaged location. At least three gaging stations and(or) partial-record stations are chosen for the estimation of low-flow statistics at the ungaged site. Sites affected by known point sources or withdrawals are not chosen. The drainage area at the ungaged site, again, is an essential factor in estimating low-flow statistics. The low-flow values from each of the nearby sites are divided by the drainage area to give a flow per square mile value. The average flow per square mile from the nearby sites is multiplied by the drainage area at the ungaged site to obtain an estimated low-flow value.

The following example represents a calculation of determining the 1-, 7-, and 30-day 10-year low flows on an unnamed tributary to Lake Iliff. Lake Iliff is located on an unnamed tributary to the Pequest River (fig. 22). No streamflow data are available for the unnamed tributary to the Pequest River. The drainage basin at the specified location was delineated and found to drain an area of $0.28 \mathrm{mi}^{2}$. The low-flow sites on the Pequest River at Huntsville (01445000), the Wallkill River at the outlet of Lake Mohawk at Sparta (01367620), and the discontinued gaging station on the East Branch Paulins Kill tributary 2 at Woodruff (01443260) (fig. 22) were chosen to represent low flows in the area. All three sites are located within a 5-mile radius of the ungaged site. The flow statistics at each of the three sites were computed from MOVE1 correlation analysis. The statistics were converted to a flow-per-square-mile value and averaged with the flow-per-square-mile values estimated at the other two sites. For the 7Q10 flow, the flow-per-squaremile values were very close. The three values ranged from $0.062 \mathrm{ft}^{3} / \mathrm{s} / \mathrm{mi}^{2}$ to $0.075 \mathrm{ft}^{3} / \mathrm{s} / \mathrm{mi}^{2}$. The average flow per square mile $\left(0.068 \mathrm{ft}^{3} / \mathrm{s} / \mathrm{mi}^{2}\right)$ was multiplied by the drainage area of $0.28 \mathrm{mi}^{2}$ to give an estimate of $0.019 \mathrm{ft}^{3} / \mathrm{s}$. Estimated flows are rounded to the nearest $0.1 \mathrm{ft}^{3} / \mathrm{s}$, resulting in an estimate of $0.0 \mathrm{ft}^{3} / \mathrm{s}$.

\section{Ungaged Sites Downstream from a Permitted Point Source}

Low-flow statistics at ungaged sites downstream from major permitted point sources can be estimated from data for gaging stations or low-flow sites, including sites affected by permitted point-source discharge, or from data for sites that are unaffected by the discharge. Streamflow data for sites on the stream are preferred and are used when available. The flow-per-square-mile value at a site located downstream from the major point source is used when point-source discharge is included in the estimate. When natural streamflow estimates are requested, statistics are computed from streamflow data for gaging stations and partial-record stations upstream from the point source and other sites on unregulated streams in the area. Streamflow statistics for these sites are divided by the drainage area at the site. The flow-per-square-mile values for all the sites chosen in the area are averaged. The average value is multiplied by the drainage area at the ungaged site. When natural streamflow estimates are requested, data from sites downstream from the major point source are not used because the permitted discharge cannot be deducted accurately from the streamflow data because historical records of point-source 


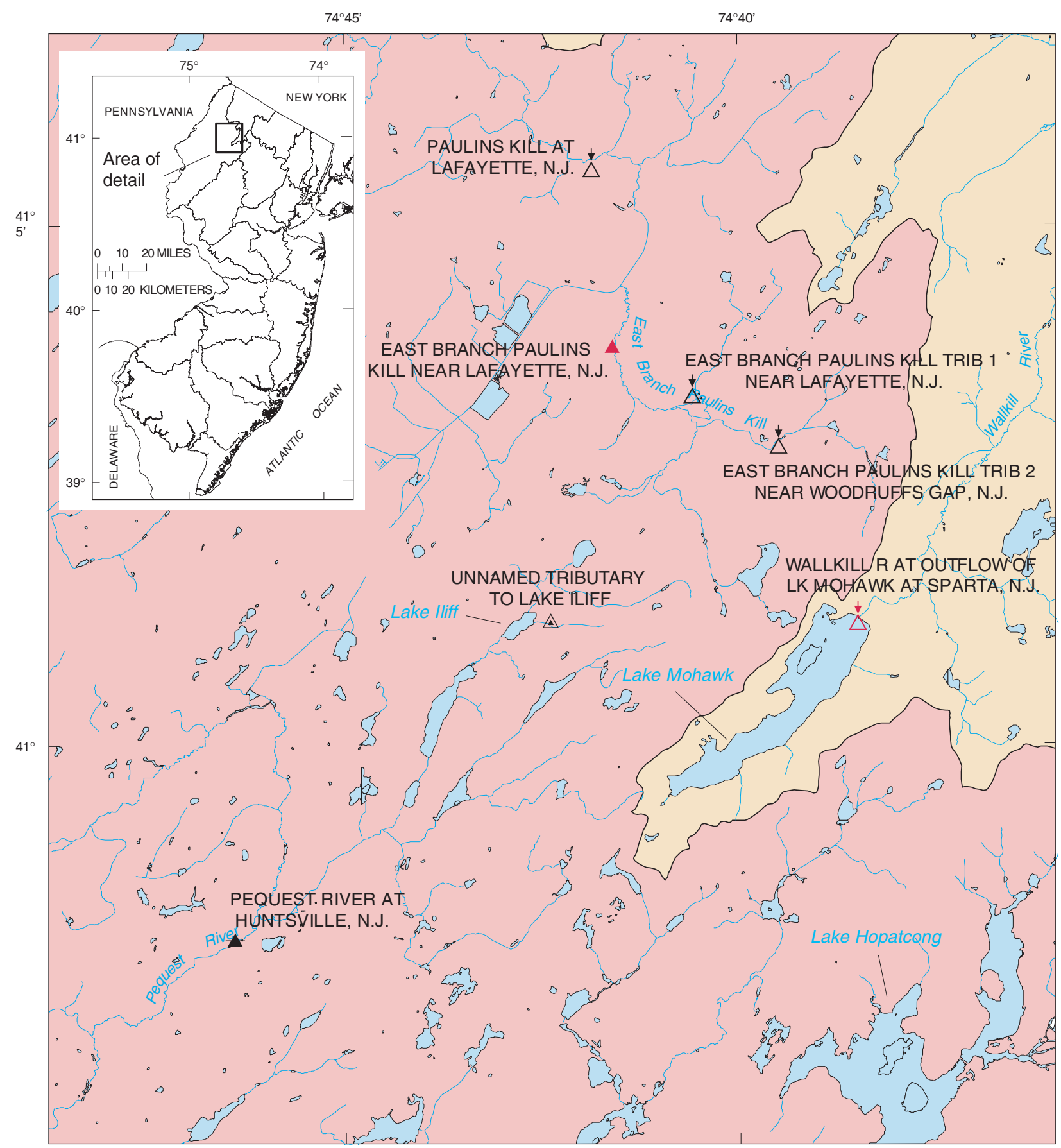

Base from U.S. Geological Survey digital line graph files, 1:24,000

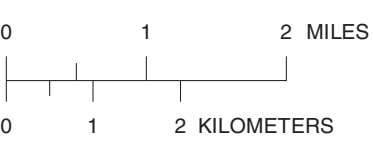
WATERSHED MANAGEMENT
AREAS

Upper Delaware

Wallkill

\section{EXPLANATION}

TREAMFLOW-GAGING STATIONS LOW-FLOW PARTIAL-RECORD

$\Delta$ Active

$\Delta$ Inactive

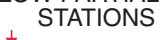

$\downarrow$

$\triangle$ Active

$\triangle$ Inactive

OTHER SITE

$\triangle$ Ungaged site

Figure 22. Locations of an ungaged site on an unnamed tributary to Lake lliff and continuous-record streamflow-gaging stations and low-flow partial-record stations in the Upper Delaware and Wallkill Watershed Management Areas in New Jersey. 
discharge usually are not readily available. Current data (2005) on discharges from permitted point sources are more readily available than historical data; however, discharges vary over time and accurate adjustments to historical streamflow cannot be computed.

\section{Summary and Conclusions}

Streamflow measurements and statistics are needed by engineers, water managers, and planners. High-flow statistics are used to design bridges, dams, and flood-control structures, whereas low-flow statistics are used for allocating surfacewater withdrawals and for setting waste-load allocation limits. The statistics also are a critical part of studies of total maximum daily loads. In order to update streamflow statistics for New Jersey the U.S. Geological Survey (USGS), in cooperation with the New Jersey Department of Environmental Protection (NJDEP), analyzed the continuous records of streamflow at 111 gaging stations throughout New Jersey with 20 or more years of record through the 2001 water year. The characteristics presented for the long-term continuous-record stations are minimum, maximum, and mean daily streamflow; harmonic mean flow; 1-,7-, and 30-day minimum average low flow with 2-, 5-, 10-, and 20-year recurrence intervals; 1-,7-, and 30-day maximum average high flow with 2-, 5-, 10-, and 25-year recurrence intervals; and 1-, 2-, 5-, 10-, 20-, 25-, 30-, 40-, 50-, 60-, 70-, 75-, 80-, 85-, 90-, 95-, 99-percent daily flow durations. Flow frequencies and flow durations are presented for both annual and winter (November through April) periods.

Instantaneous measurements of streamflow at low-flow conditions at 500 partial-record stations, including 66 gaging stations with less than 20 years of record, were used to estimate streamflow statistics for these sites. MOVE1 correlation analysis was used to relate instantaneous base-flow measurements at the partial-record stations to daily mean discharges at long-term continuous-record gaging stations. The characteristics presented for the partial-record stations are daily mean flow; harmonic mean flow; and 1-, 7-, and 30-day minimum average low flow with a 10 -year recurrence interval for the annual and winter periods.

Tables of the streamflow statistics reported in this document are available on the USGS World Wide Web site at http://pubs.water.usgs.gov/sir20055105/. Information presented on the Web site will be updated to include revised estimates of statistics at partial-record stations as new data are collected and MOVE1 correlations are rerun and analyzed.

Harmonic mean flow was computed for all the gaging stations with 10 or more years of record and estimated for all partial-record stations. Harmonic mean flows at gaging stations were compared to statistics of flow duration and low-flow frequency by evaluating percent differences at each site and by using ordinary least squares regression. The statistic most closely related to the harmonic mean flow, when studying all gaging stations in the study area, was the 75-percent flow.

The variability in streamflow at a gaging station was measured using the coefficient of variation, the ratio of instantaneous peak flow to 3-day mean flow surrounding the peak, the ratios of 25-percent/75-percent and 10-percent/90-percent flow durations, and the ratios of 1-day 2-year high flow/1-day 2-year low flow and 1-day 20-year high flow /1-day 20-year low flow. Streamflow variability was significantly greater among the group of gaging stations located outside the Coastal Plain than the group of gaging stations located inside the Coastal Plain. The median value of the 25 -percent/75-percent ratio was 4.12 for the 38 analyzed gaging stations outside the Coastal Plain and 2.16 for the 20 analyzed gaging stations in the Coastal Plain. Streamflow variability also was compared between gaging stations in different land-use categories. In the Coastal Plain, significant differences in streamflow variability were found between gaging stations draining areas with more than 30-percent developed land and those draining areas with more than 70-percent undeveloped land. Variability was greater in the developed basins.

Trend tests were run on the annual 1-, 7-, and 30-day high- and low-flow data sets. The percentages of gaging stations with significant high-flow trends were 16, 13, and 7 for the annual 1-, 7-, and 30-day periods, respectively. The percentages of gaging stations with significant low-flow trends were 25,25 , and 20 for the annual 1-, 7-, and 30-consecutiveday periods, respectively.

The trend analysis for the unregulated gaging stations identified as undeveloped sites did not indicate high-flow trends, except for the 7-day mean at one gaging station. The results of trend tests for high flows indicate relations between upward trends for high flows and stream regulation, and high flows and development in the basin. The relation between development and low-flow trends does not appear to be as strong as for development and high-flow trends.

A significant upward trend in precipitation in northern New Jersey, Climate Division 1 was identified. For Climatic Division 2, no general increase in average precipitation was observed. Trend test results indicate that high flows at undeveloped, unregulated sites have not been affected by the increase in average precipitation. The high-flow trends at regulated and unregulated gaging stations could be associated with increased development.

Low-flow statistics are estimated for stream sites with no flow data. Procedures are presented for estimating statistics at ungaged sites on streams with (1) streamflow data and no regulation, (2) streamflow data and regulation, (3) no streamflow data and no regulation, and (4) no streamflow data downstream from a permitted point source. 


\section{Literature Cited}

Anderson, J.R., Hardy, E.E., Roach, J.T., and Witmer, R.E., 1976, A land use and land cover classification system for use with remote sensor data: U.S. Geological Survey Professional Paper 964, $28 \mathrm{p}$.

Bauersfeld, W.R., and Schopp, R.D., U.S. Geological Survey, and M.D. Shulman, Rutgers University, 1988-89, National Water Summary 1988-1988—Floods and Droughts: New Jersey: U.S. Geological Survey Water-Supply Paper 2375, p. 401-408.

Buchanan, T.J., Miller, E.J., and Ludlow J.M., 1965, Baseflow relations for partial-record stations in New Jersey: U.S. Geological Survey Open-File Report, 19 p.

CH2M Hill, Metcalf \& Eddy, Inc., and New Jersey First, Inc., 1992, New Jersey Statewide Water Supply Masterplan, Task 2 Report, Water Supply Baseline Data Development and Analyses: Trenton, N.J., New Jersey Department of Environmental Protection and Energy, 36 p.

Flynn, K.M., Hummel, P.R., Lumb, A.M., and Kittle, J.L., 1995, User's manual for Annie, version 2, a computer program for interactive hydrologic data management: U.S. Geological Survey Water-Resources Investigation Report 95-4085, 211 p.

Gillespie, B.D., and Schopp, R.D., 1982, Low-flow characteristics and flow duration of New Jersey streams: U.S. Geological Survey Open-File Report 81-1110, 164 p.

Helsel, D.R., and Hirsch, R.M., 2002, Statistical methods in Water Resources: U.S. Geological Survey Techniques of Water-Resources Investigations, book 4, chap. A3, 510 p.

Hirsch, R.M., 1982, A comparison of four streamflow record extension techniques: Water Resources Research, v. 18, no. 4, p. 1081-1088.

Jarrell, W.M., 1999, Getting started with TMDLs: Portland, Oregon, Oregon Graduate Institute of Science and Technology, 86 p.

Langbein, W.B., and Iseri, K.T., 1960, General introduction and hydrologic definitions: U.S. Geological Survey WaterSupply Paper 1541-A, 29 p.

Martin, G.R., and Ruhl, K.J., 1993, Regionalization of harmonic mean streamflows in Kentucky: U.S. Geological Survey Water-Resources Investigations Report 92-4173, $47 \mathrm{p}$.
National Oceanic and Atmospheric Administration, 2000, Climate Division database (Last month with final data: September 2002) (Accessed February 3, 2003, from File Transfer Protocol site at URL ttp://ftp.ncdc.noaa.gov/pub/data/cirs/drd964x.pct.txt).

New Jersey Department of Environmental Protection and Energy, 1992, Geologic map of New Jersey: Trenton, N.J., New Jersey Department of Environmental Protection and Energy, New Jersey Geological Survey, scale 1:1,000,000.

New Jersey Department of Environmental Protection, 2000, 1995/97 Landuse/Landcover by Watershed Management Area (WMA): Trenton, N.J. (Available from http://www.state.nj.us/dep/gis/lulc95shp.html).

Ott, L., 1988, An introduction to statistical methods and data analysis: Boston, Mass., PWS-Kent Publishing Company, $835 \mathrm{p}$.

Reed, T.J., White, B.T., Centinaro, G.L., Dudek, J.F., Spehar, A.B., Protz, A.R., Shvanda, J.C., Watson, A.F., and Holzer, G.K., 2003,Water-resources data New Jersey-water year 2002, Volume 1. Surface-water data: U.S. Geological Survey Water-Data Report NJ-02-1, 364 p.

Reiser, R.G., and O'Brien, A.K., 1998, Occurrence and seasonal variability of volatile organic compounds in seven New Jersey streams: U.S. Geological Survey WaterResources Investigations Report 98-4074, 11 p.

Riggs, H.C., 1968, Frequency curves: U.S. Geological Survey Techniques of Water-Resources Investigations, book 4, chap. A2, 15 p.

Riggs, H.C., 1972, Low-flow investigations: U.S. Geological Survey Techniques of Water-Resources Investigations, book 4, chap. B1, $18 \mathrm{p}$.

Rossman, L.A., 1990, DFLOW user's manual: Cincinnati, Ohio, U.S. Environmental Protection Agency, Risk Reduction Engineering Laboratory, $26 \mathrm{p}$.

Searcy, J.K., 1959, Flow-duration curves: U.S. Geological Survey Water-Supply Paper 1542-A, 33 p.

Smock, J.C., 1897, Annual report of the State Geologist for the year 1896: Geological Survey of New Jersey, 374 p.

Telis, P.A., 1991, Low-flow and flow-duration characteristics of Mississippi streams: U.S. Geological Survey WaterResources Investigations Report 90-4087, 23 p.

Watt, M.K., 2000, A hydrologic primer for New Jersey watershed management: U.S. Geological Survey WaterResources Investigations Report 00-4140, 108 p. 


\section{Glossary}

\section{B}

base flow Sustained or fair weather streamflow in the absence of direct runoff. It includes natural and human-induced streamflows. Natural base flow is sustained largely by ground-water discharge.

\section{C}

climatic year A continuous 12-month period during which a complete annual cycle occurs, arbitrarily selected for the presentation of data relative to hydrologic or meteorlogic phenomena. The climatic year is usually designated by the calendar year during which the most of the 12 months occur.

coefficient of variation The standard deviation divided by the mean for a given data series, a dimensionless measure of relative variability.

continuous-record streamflow-gaging station (gaging station) A site on a stream, canal, lake, or reservoir where systematic observations of gage height or discharge are obtained, a site where data are recorded with sufficient frequency to define daily mean values and variations within a day.

cubic foot per second (ft $\mathbf{f t}^{3} / \mathbf{s}$ or $\mathbf{c f s}$ ) The rate of streamflow representing a volume of 1 cubic foot passing a given point in 1 second.

\section{D}

daily mean streamflow data Average of the continuous record of streamflow at regular, pre-determined intervals during the day.

design flow The regulatory streamflow used to establish New Jersey Department of Environmental Protection water-quality criteria and permit requirements.

diversion In this report, a diversion is the taking of water from a stream or other body of water into a canal, pipe, or other conduit.

drainage area Land area measured in the horizontal plane, upstream from a specific location on a stream where runoff from precipitation and discharge from ground-water sources drain by gravity into the stream.

$\mathbf{F}$

flow, natural The flow of a stream as it occurs under natural conditions; that is, not subjected to any regulation or diversion.

flow, regulated The flow of a stream that has been subjected to any artificial or manmade storage, augmentation, or diversion.

flow-duration curve A cumulative-frequency curve that shows the percentage of time that specified discharges are exceeded. The flow-duration curve is based on daily mean flow from the period of record, but the chronologic sequence of flows is omitted from consideration in the preparation of the curve. Therefore, it is impossible to tell from the flow-duration curve alone whether varying periods of low flow all occurred during one drought period or were scattered over a number of years. The flow-duration curve is, however, useful for studying the flow characteristics of a stream over its entire range of discharge.

\section{G}

gaging station A site on a stream, canal, lake, or reservoir where systematic observations of gage height or discharge are obtained.

\section{L}

low-flow frequency curve A graph showing the relation between the magnitude and frequency of the annual lowest mean flow for a given number of consecutive days. Lowflow frequency is expressed as the average interval, in years, between recurrences of an annual minimum flow less that shown by the magnitude scale. The low-flow frequency relation is commonly presented as a family of curves with a separate curve for each number of consecutive days. 
low-flow partial-record station (partialrecord station) A site where discrete measurements of one or more hydrologic characteristics are obtained over a period of time without continuous data being recorded or computed.

\section{$\mathbf{P}$}

peak flow The maximum instantaneous flow of a stream or river at a given location. This flow usually occurs at or near the time of maximum stage.

peak ratio Computed from annual peak flow, which is the maximum instantaneous streamflow value for the water year, divided by the 3-day mean flow for 3 consecutive days including the day before, day of, and day after the peak. Peak ratio is a measure of the magnitude of the rise and fall of a stream over a given period of time.

\section{R}

regulation Artificial manipulation of the flow of a stream, such as artificial lakes, the operation of reservoirs, and for example cranberry bogs in Southern New Jersey.

recurrence interval The time interval, in years, within which a given hydrologic event will, on the average, be less or more than a given value one time. It is the reciprocal of the probability that the given hydrologic event will not be exceeded or will be exceeded in any one year. For example, a 20-year low flow is one that has a 5 percent chance of not being exceeded in any one year.

\section{S}

standard error of estimate Computed using the standard error of prediction of the MOVE. 1 line and the time-sampling error for the index station (Telis, 1991).

standard error of prediction Measure of the fit of the correlation of discharge data for two stations for a MOVE.1 line (Telis, 1991).

\section{T}

total maximum daily loads (TMDLs) The maximum quantity of a contaminant that can enter a water body without adversely affecting the beneficial uses of the water body (Jarrell, 1999).

\section{W}

water year In U.S. Geological Survey reports dealing with surface-water supply, the water year is the 12-month period, October 1 through September 30, designated by the calendar year in which it ends. 


\section{Tables 3 and 4}




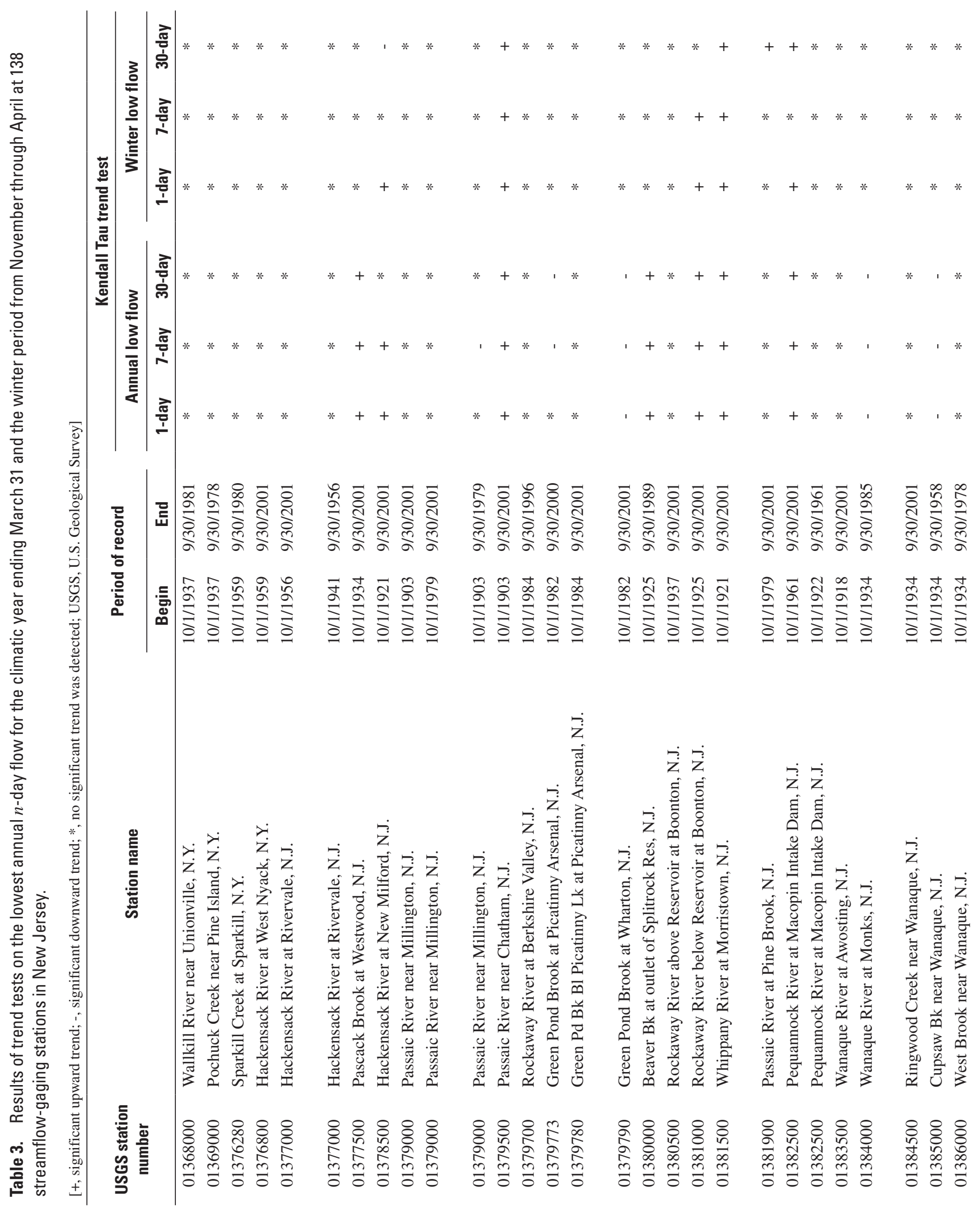




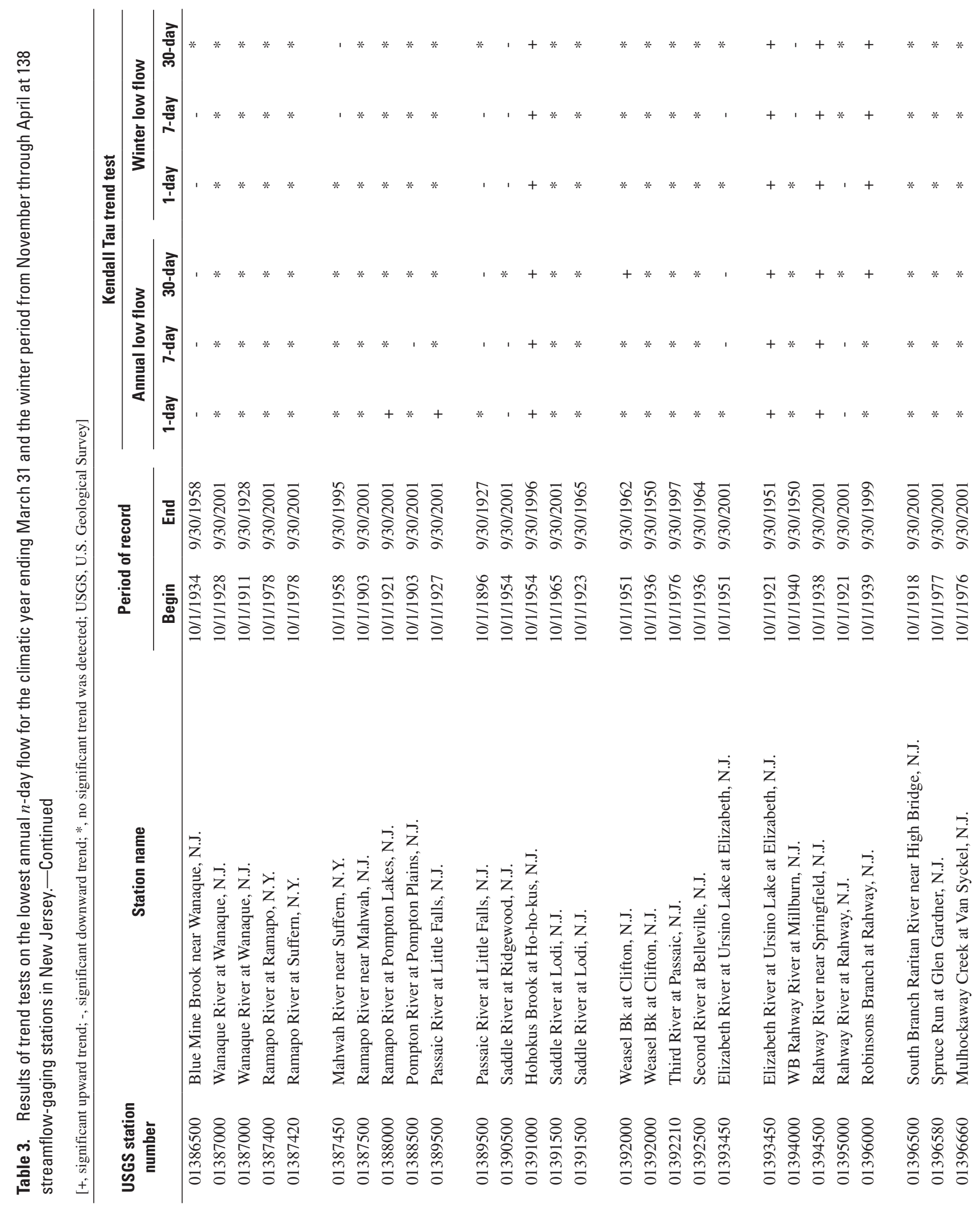




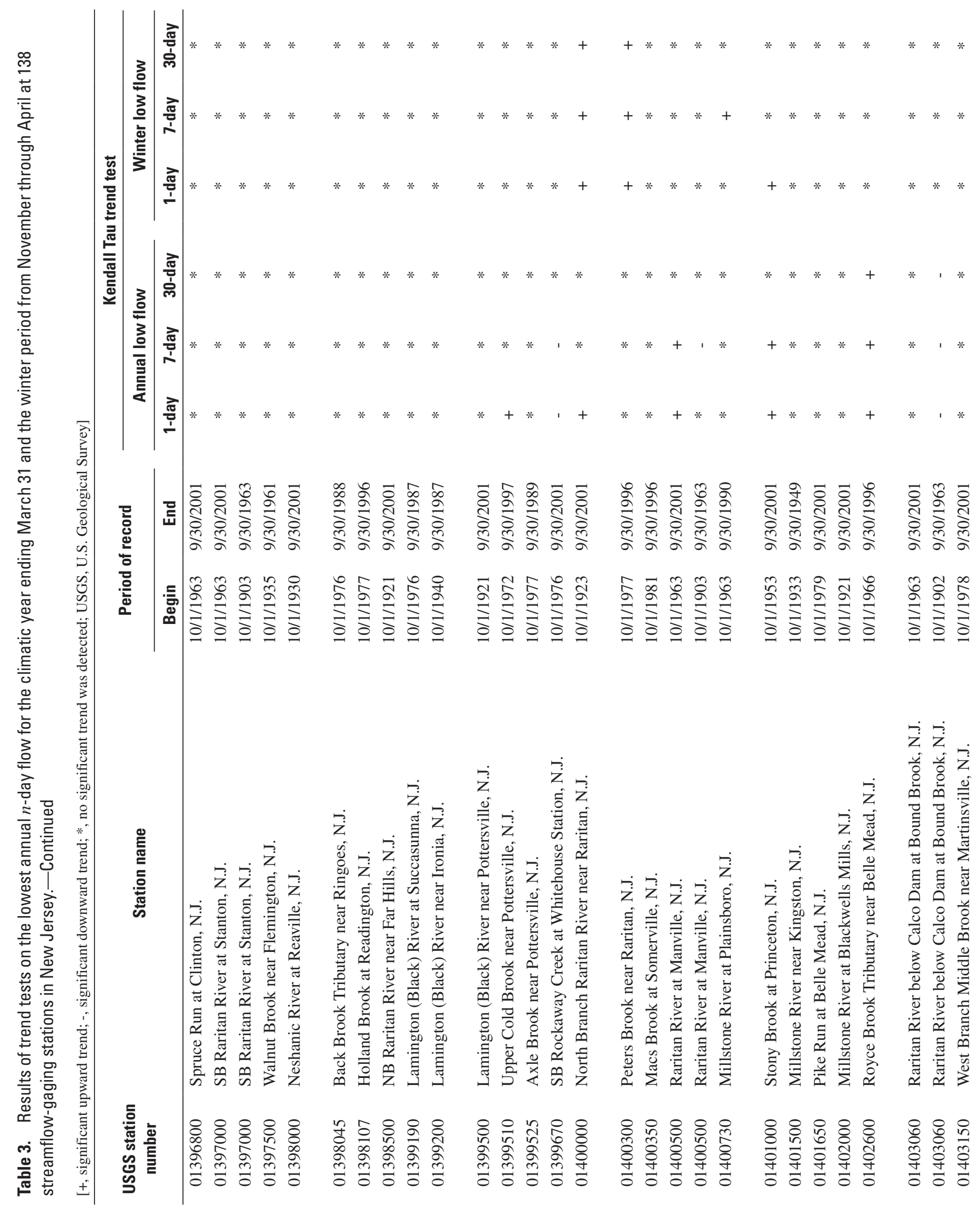




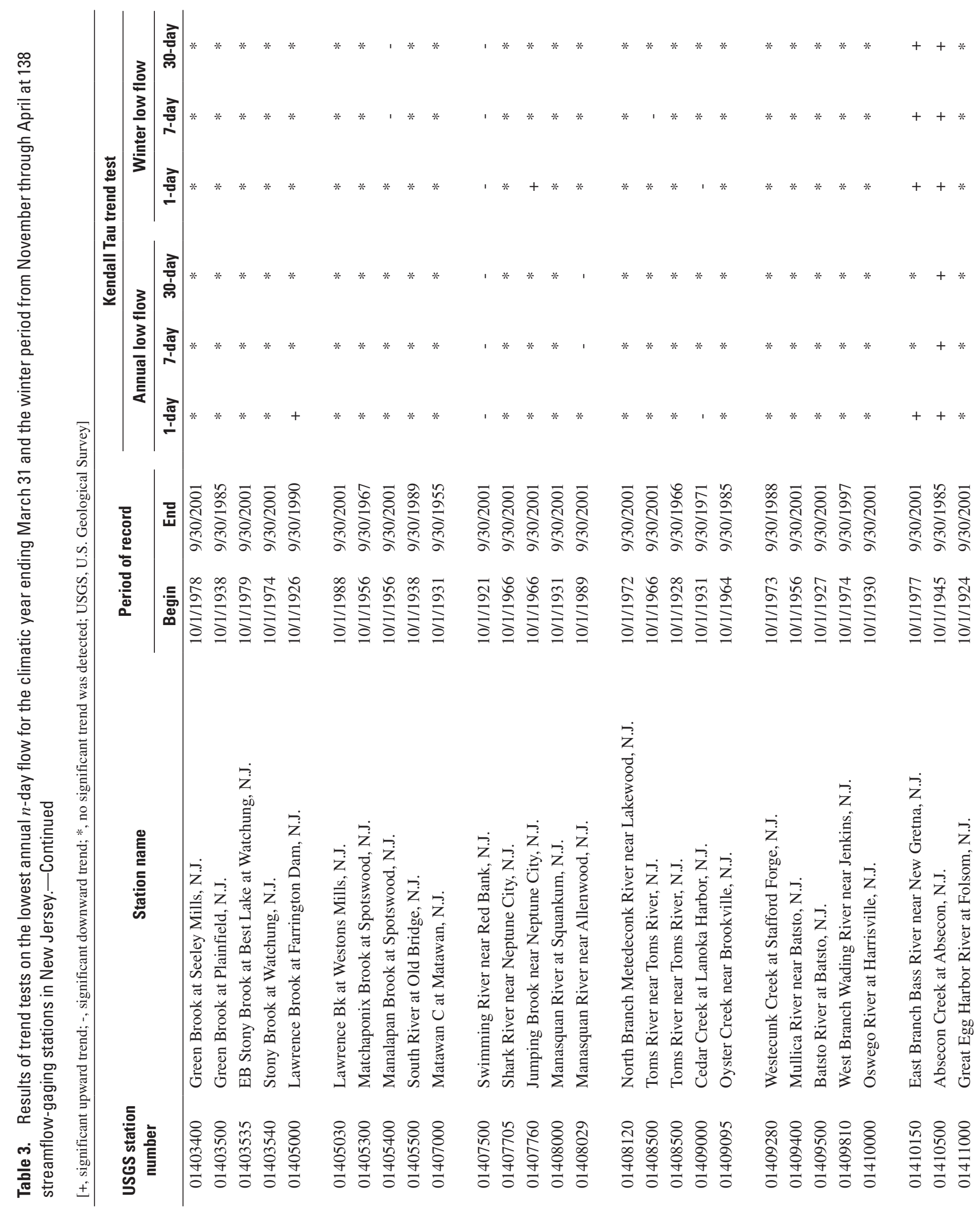




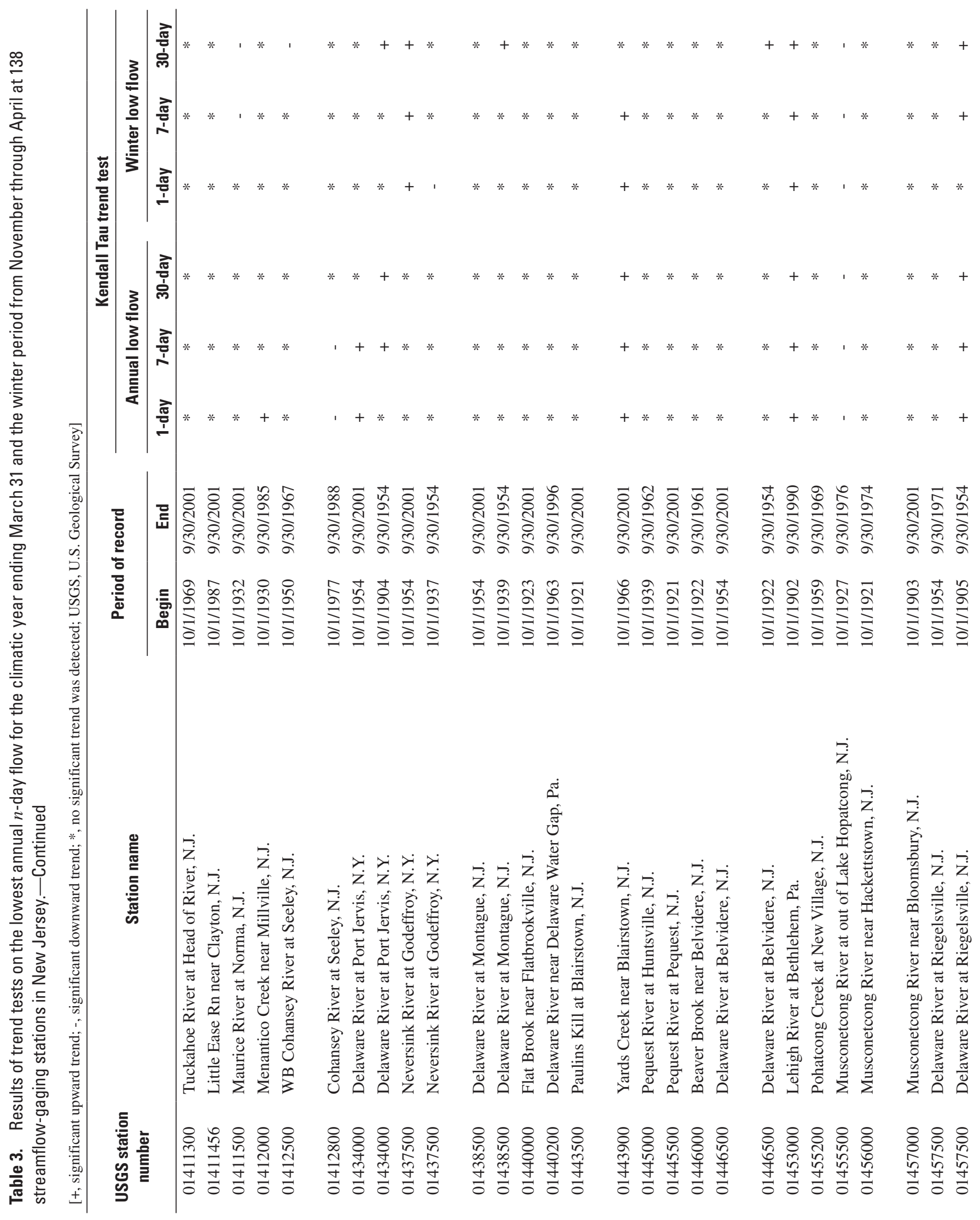




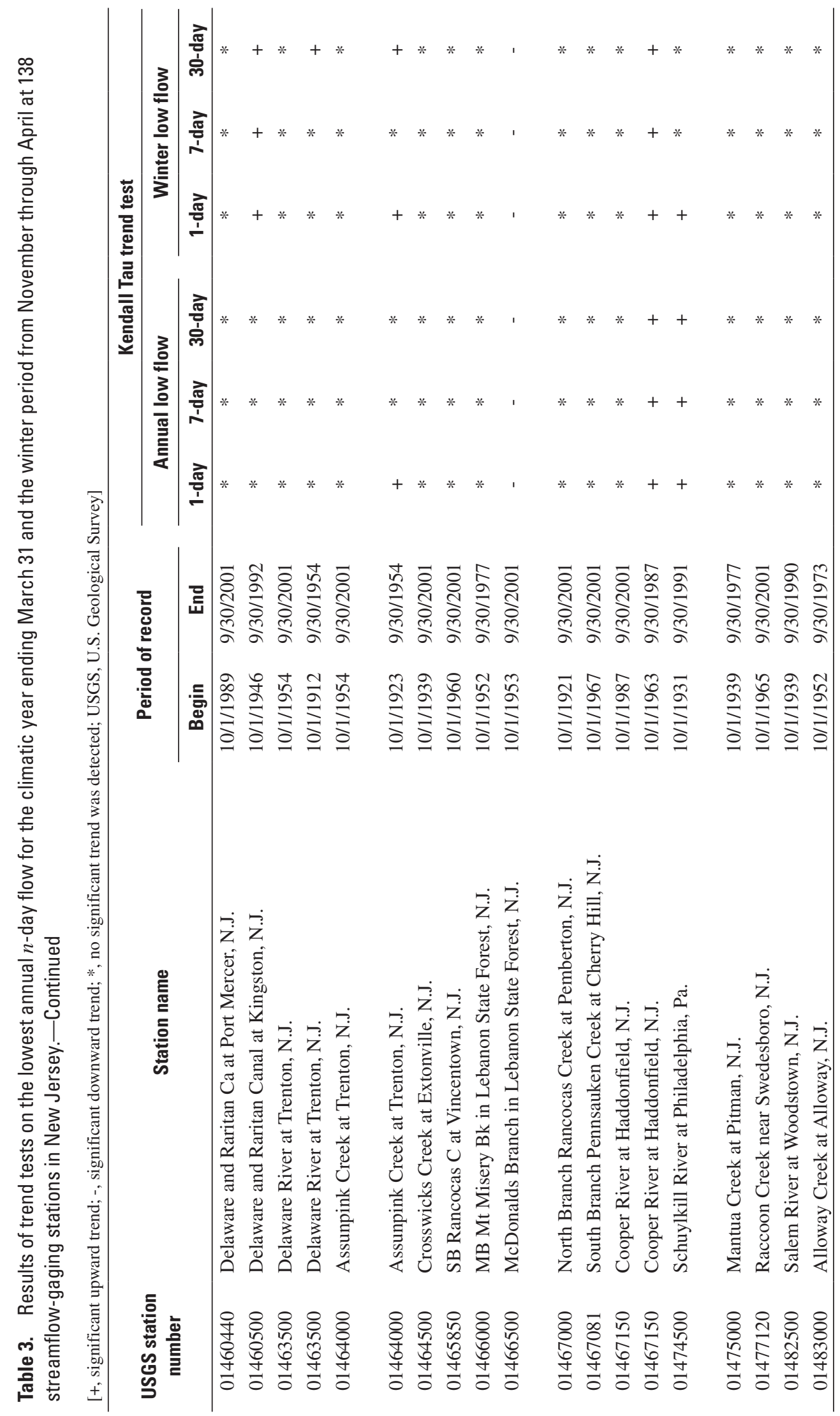



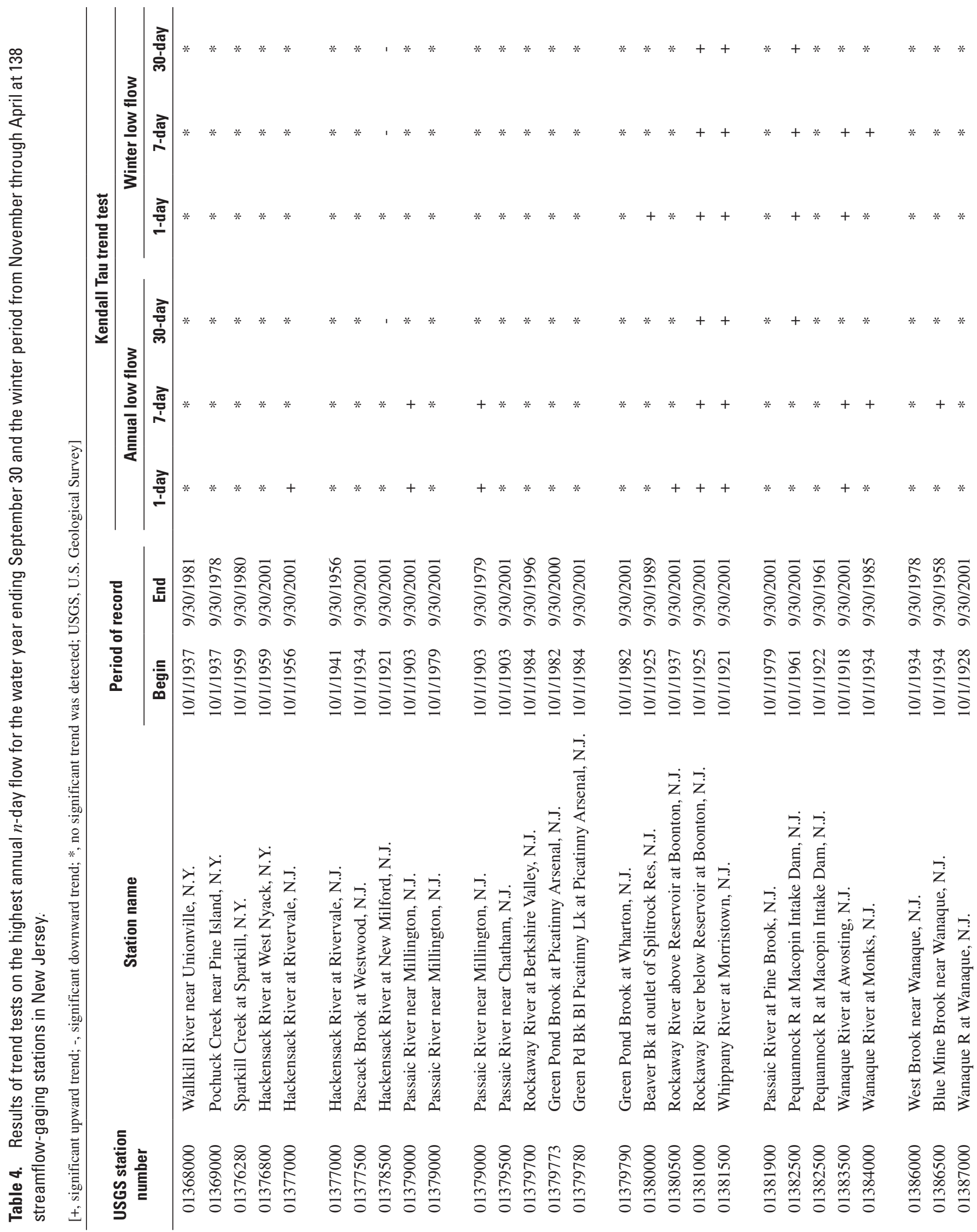


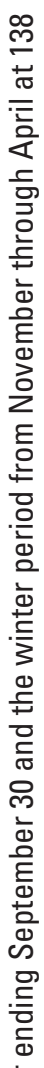

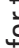

중

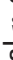

.

\section{茂}

흘

$\stackrel{\circ}{\leftrightarrows}$

등

足

过.

등

幽

的

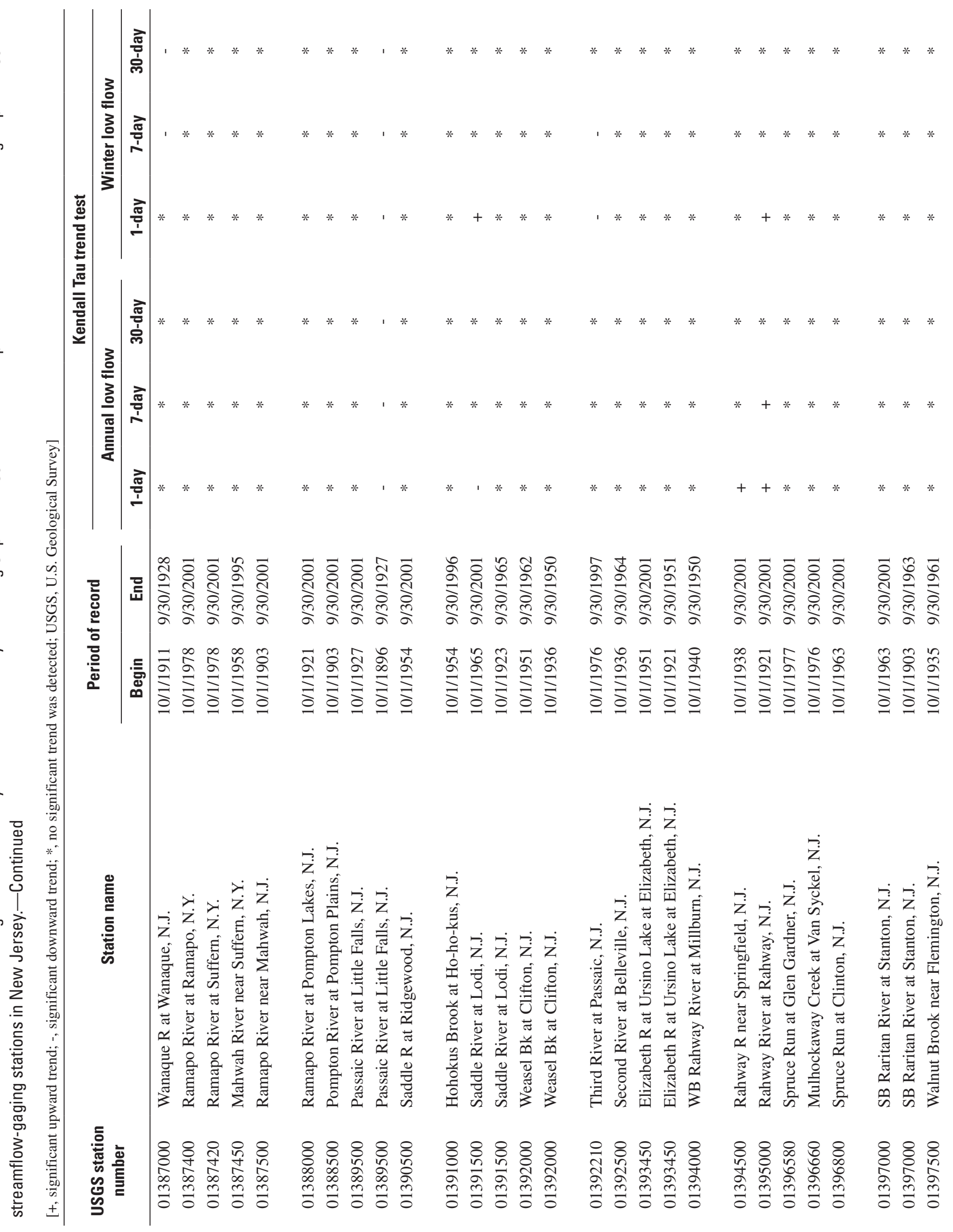



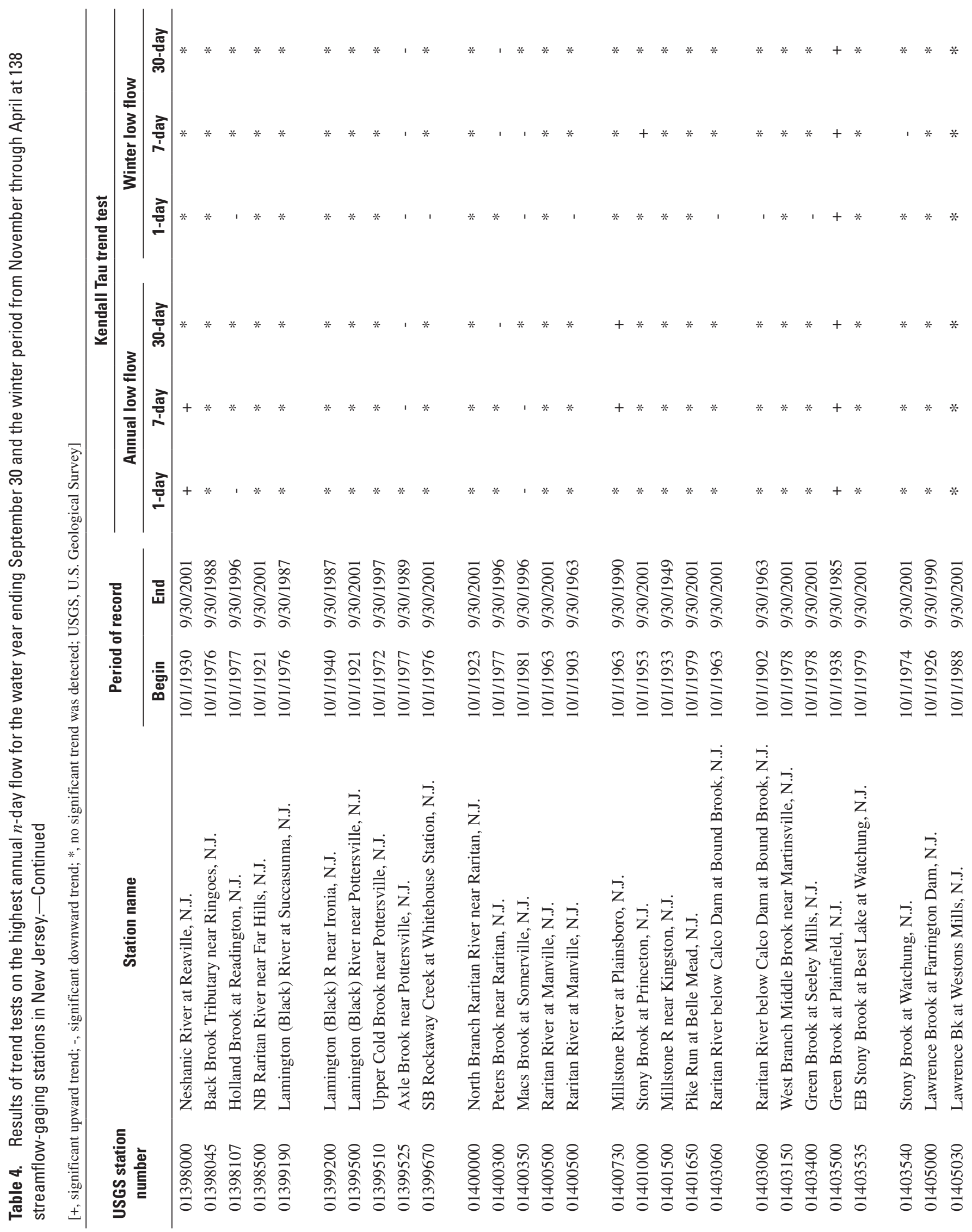
要

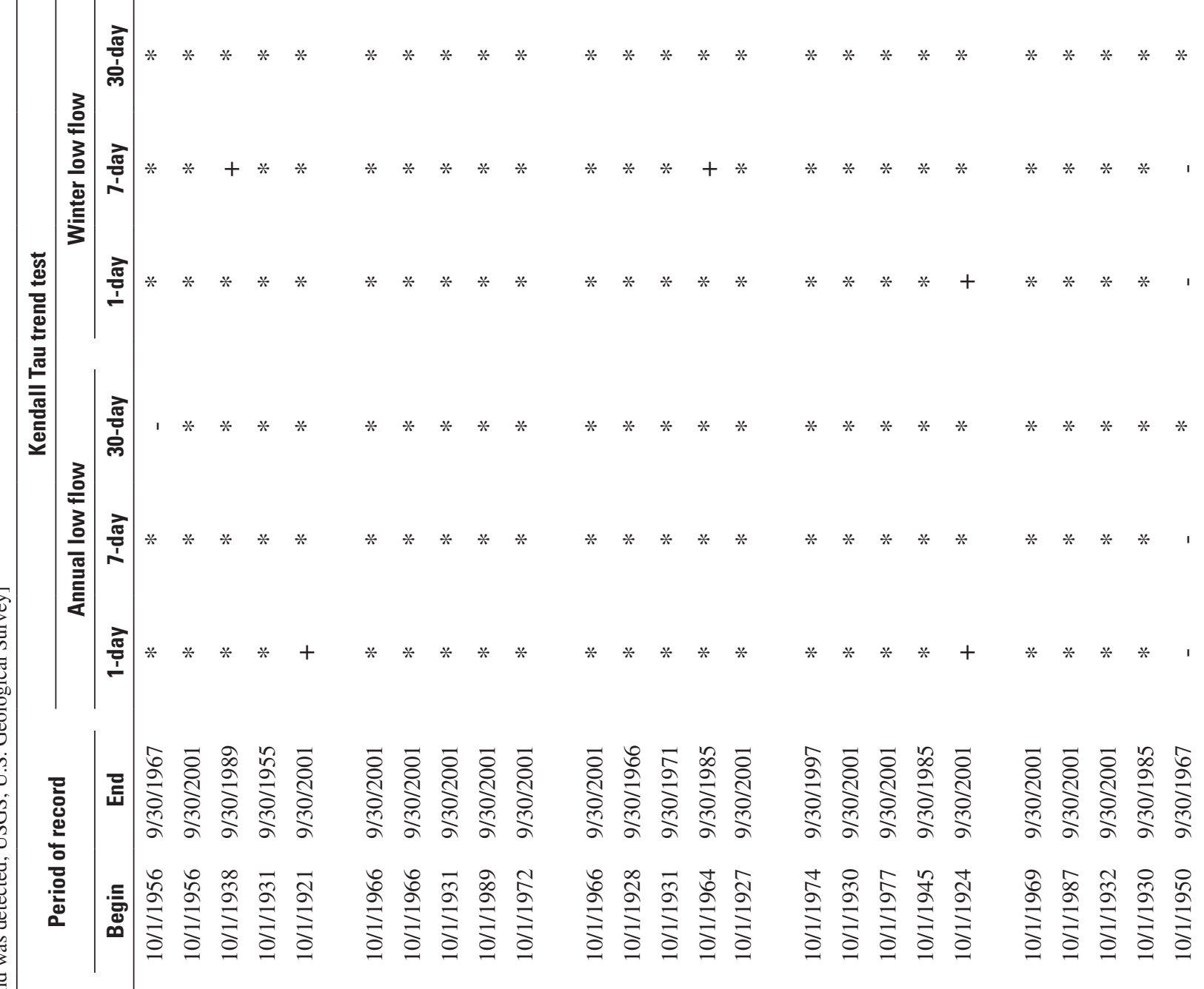

高

g

5 흘

象 Z

$\stackrel{\mathscr{J}}{\leftrightarrows}$

등

范

禀

d

சi 은

๘
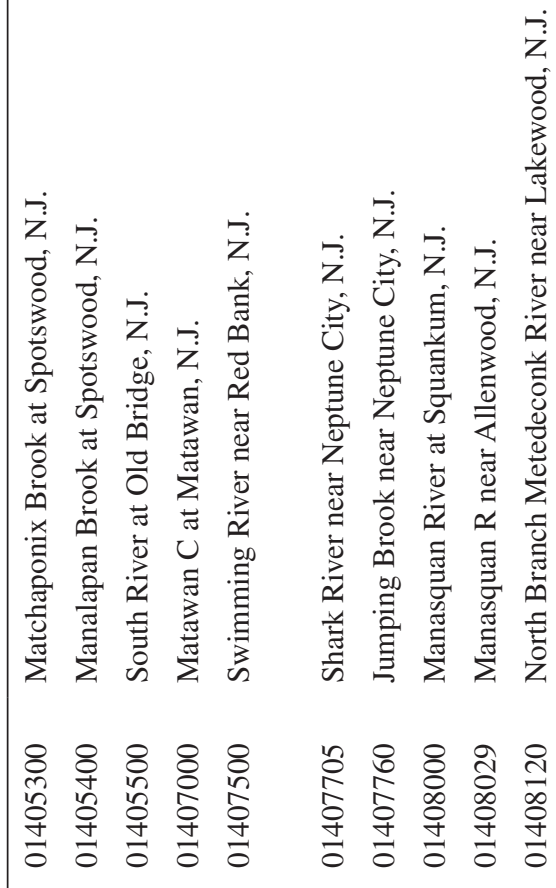

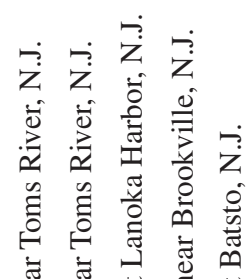

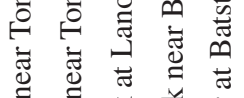

可

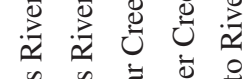

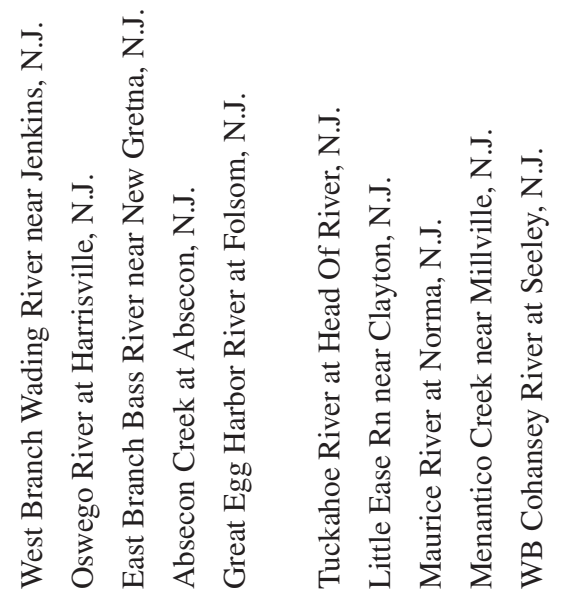

产

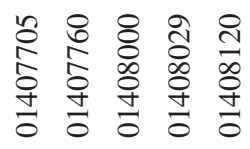

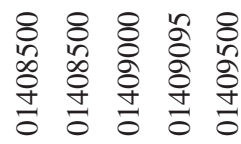

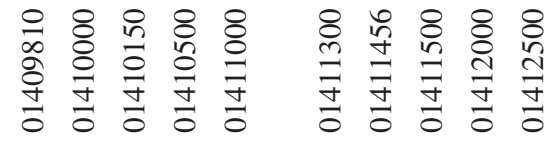




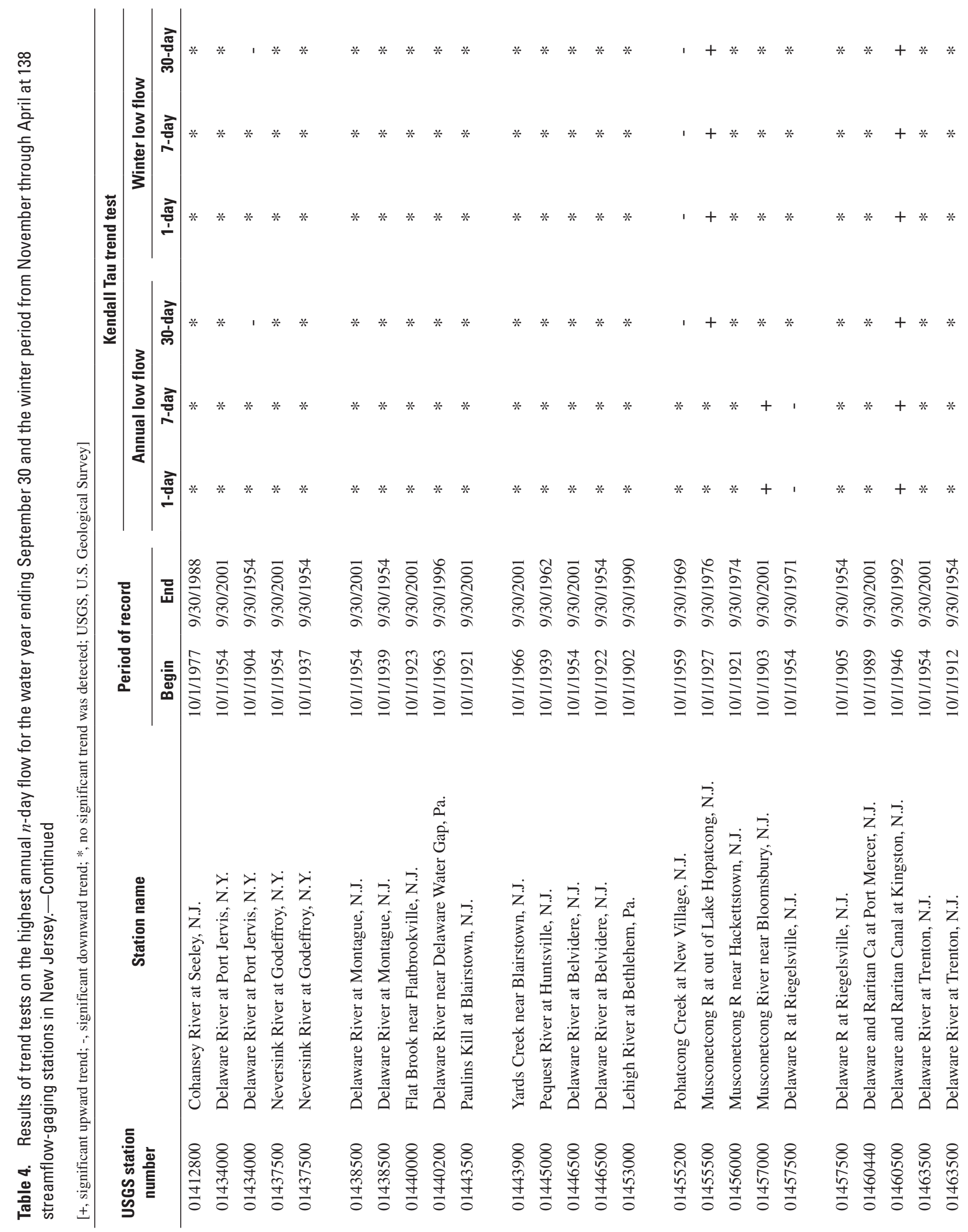




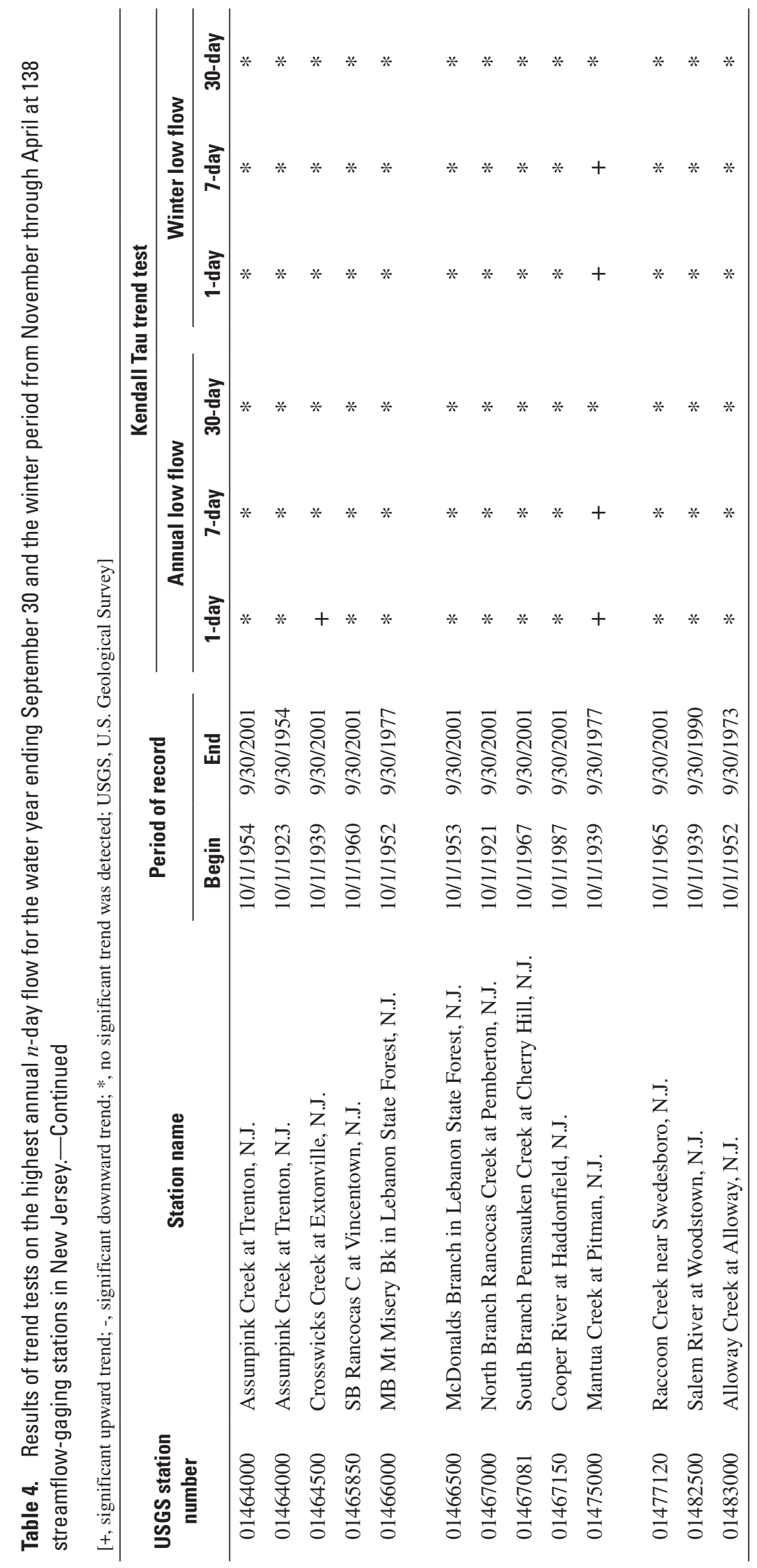



Appendix 1 
Table 1-1. Index, by station identification number, of selected continuous-record streamflow-gaging stations, low-flow partial-record stations, and gaging stations analyzed as a partial-record stations in New Jersey, New York, and Pennsylvania.

[Stations are listed in downstream order; ID, identification number]

\begin{tabular}{|c|c|c|c|c|}
\hline Station ID & Station name & Station type & $\begin{array}{l}\text { Regu- } \\
\text { lation }\end{array}$ & $\begin{array}{c}\text { Watershed } \\
\text { Manage- } \\
\text { ment Area }\end{array}$ \\
\hline 01367620 & Wallkill River at outflow of Lake Mohawk at Sparta, N.J. & Low-flow partial-record station & & 02 \\
\hline 01367700 & Wallkill River at Franklin, N.J. & Low-flow partial-record station & & 02 \\
\hline 01367750 & Beaver Run near Hamburg, N.J. & Low-flow partial-record station & & 02 \\
\hline 01367770 & Wallkill River near Sussex, N.J. & Low-flow partial-record station & & 02 \\
\hline 01367850 & West Branch Papakating Creek at McCoys Corner, N.J. & Low-flow partial-record station & & 02 \\
\hline 01367890 & Clove Brook above Clove Acres Lake, at Sussex, N.J. & Low-flow partial-record station & & 02 \\
\hline 01367900 & Clove Brook at Sussex, N.J. & Low-flow partial-record station & & 02 \\
\hline 01367910 & Papakating Creek at Sussex, N.J. & Low-flow partial-record station & & 02 \\
\hline 01368820 & Double Kill at Wawayanda, N.J. & Low-flow partial-record station & & 02 \\
\hline 01368840 & Double Kill at New Milford, N.Y. & Low-flow partial-record station & & 23 \\
\hline 01368950 & Black Creek near Vernon, N.J. & Low-flow partial-record station & & 02 \\
\hline 01369000 & Pochuck Creek near Pine Island, N.Y. & Continuous-record gaging station & & 23 \\
\hline 01376800 & Hackensack River at West Nyack, N.Y. & Continuous-record gaging station & Yes & 25 \\
\hline 01377000 & Hackensack River at Rivervale, N.J. & Continuous-record gaging station & Yes & 05 \\
\hline 01377300 & Pascack Brook at Pearl River, N.Y. & Low-flow partial-record station & & 25 \\
\hline 01377475 & Musquapsink Brook near Westwood, N.J. & Low-flow partial-record station & & 05 \\
\hline 01377500 & Pascack Brook at Westwood, N.J. & Continuous-record gaging station & Yes & 05 \\
\hline 01378520 & Hirshfeld Brook at New Milford, N.J. & Low-flow partial-record station & & 05 \\
\hline 01378530 & French Brook at New Bridge, N.J. & Low-flow partial-record station & & 05 \\
\hline 01378560 & Coles Brook at Hackensack, N.J. & Low-flow partial-record station & & 05 \\
\hline 01378590 & Metzler Brook at Englewood, N.J. & Low-flow partial-record station & & 05 \\
\hline 01378615 & Wolf Creek at Ridgefield, N.J. & Low-flow partial-record station & & 05 \\
\hline 01378690 & Passaic River near Bernardsville, N.J. & $\begin{array}{l}\text { Gaging station analyzed as a } \\
\text { partial-record station }\end{array}$ & & 06 \\
\hline 01378700 & Passaic River at outlet of Osborn Pond, N.J. & Low-flow partial-record station & & 06 \\
\hline 01378750 & Great Brook at Green Village, N.J. & Low-flow partial-record station & & 06 \\
\hline 01378800 & Primrose Brook near New Vernon, N.J. & Low-flow partial-record station & & 06 \\
\hline 01378850 & Great Brook near Basking Ridge, N.J. & Low-flow partial-record station & & 06 \\
\hline 01378900 & Black Brook near Meyersville, N.J. & Low-flow partial-record station & & 06 \\
\hline 01379000 & Passaic River near Millington, N.J. & Continuous-record gaging station & Yes & 06 \\
\hline
\end{tabular}


Table 1-1. Index, by station identification number, of selected continuous-record streamflow-gaging stations, low-flow partial-record stations, and gaging stations analyzed as a partial-record stations in New Jersey, New York, and Pennsylvania. - Continued

[Stations are listed in downstream order; ID, identification number]

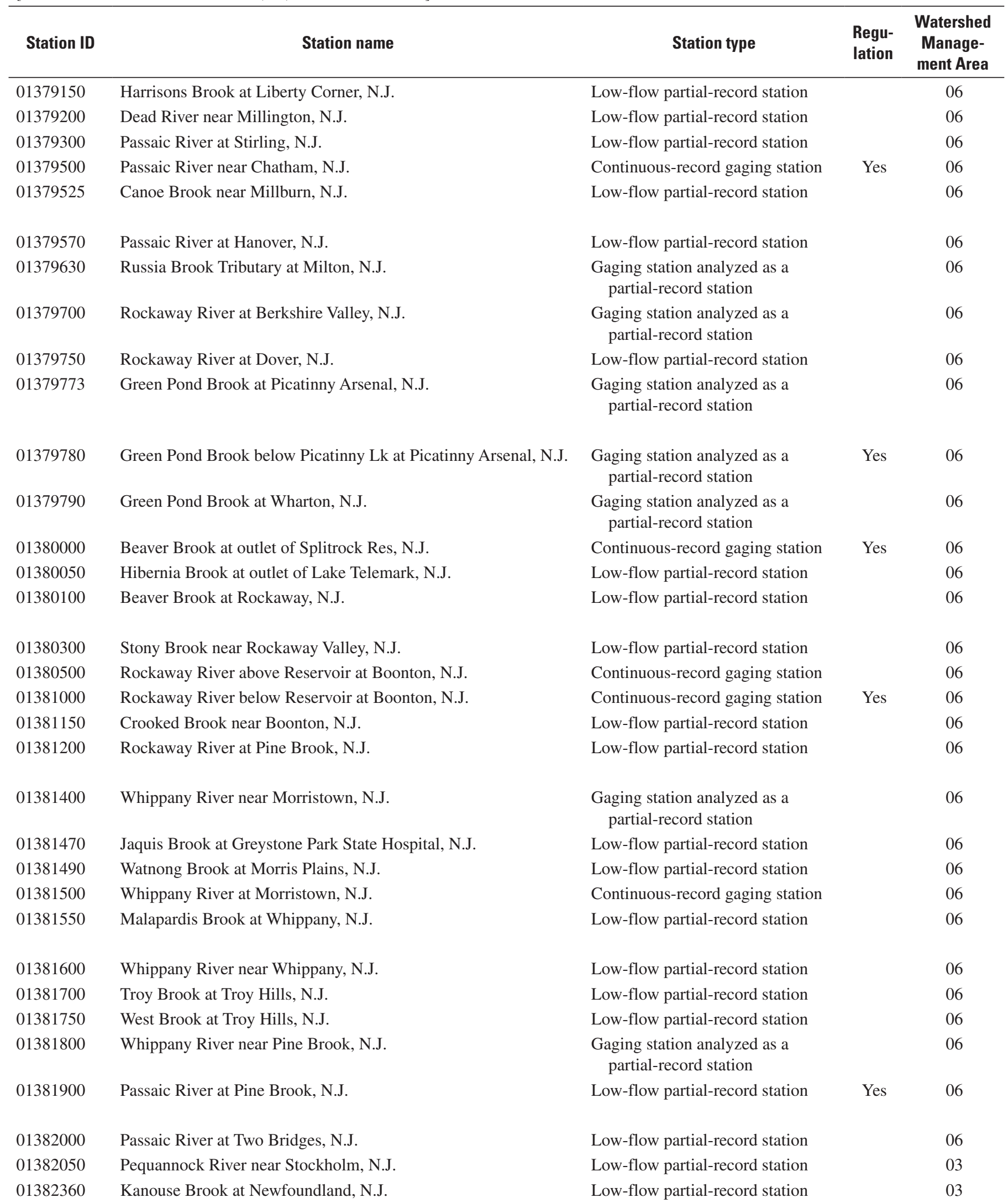


Table 1-1. Index, by station identification number, of selected continuous-record streamflow-gaging stations, low-flow partial-record stations, and gaging stations analyzed as a partial-record stations in New Jersey, New York, and Pennsylvania.-Continued

[Stations are listed in downstream order; ID, identification number]

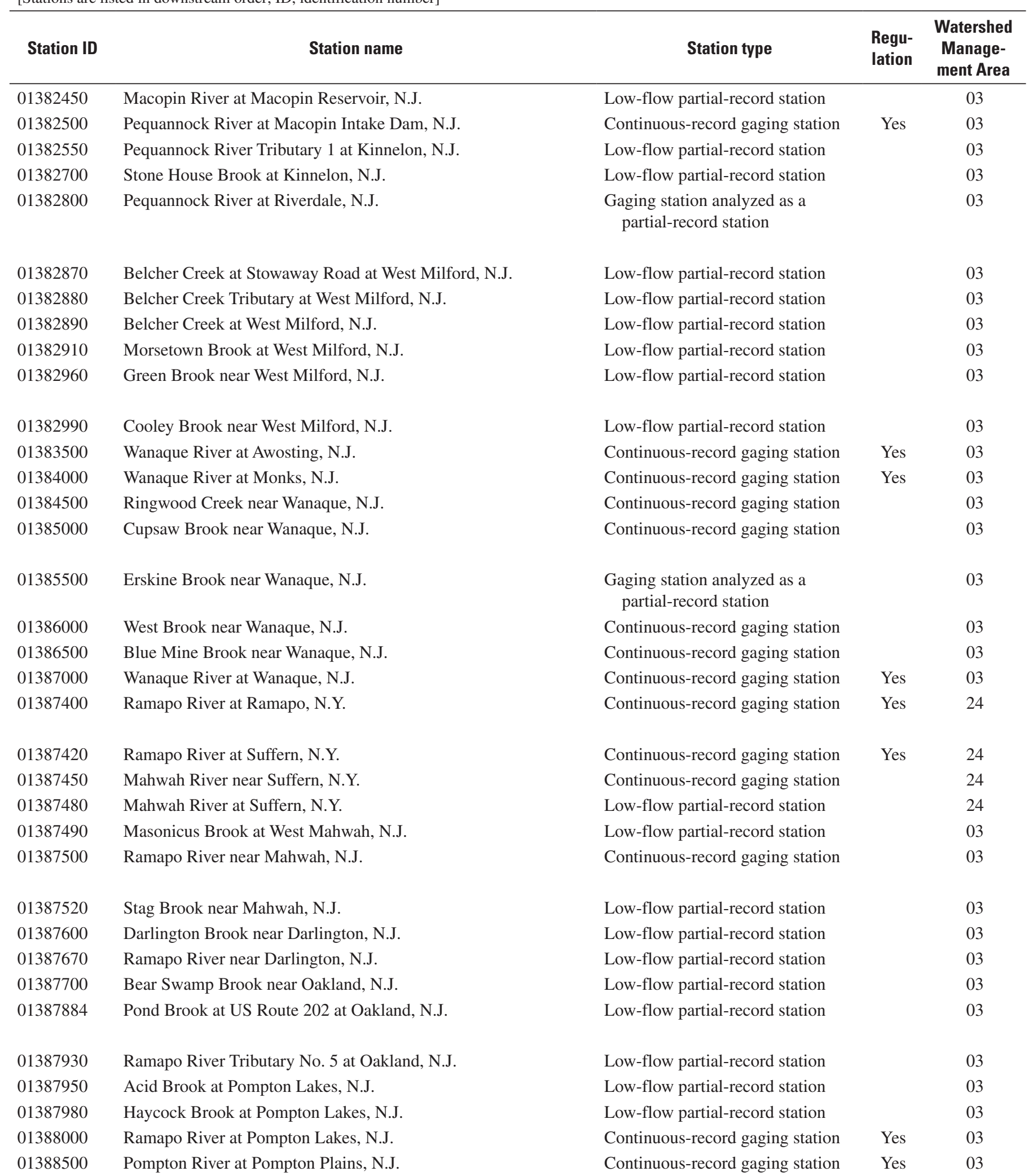


Table 1-1. Index, by station identification number, of selected continuous-record streamflow-gaging stations, low-flow partial-record stations, and gaging stations analyzed as a partial-record stations in New Jersey, New York, and Pennsylvania. - Continued

[Stations are listed in downstream order; ID, identification number]

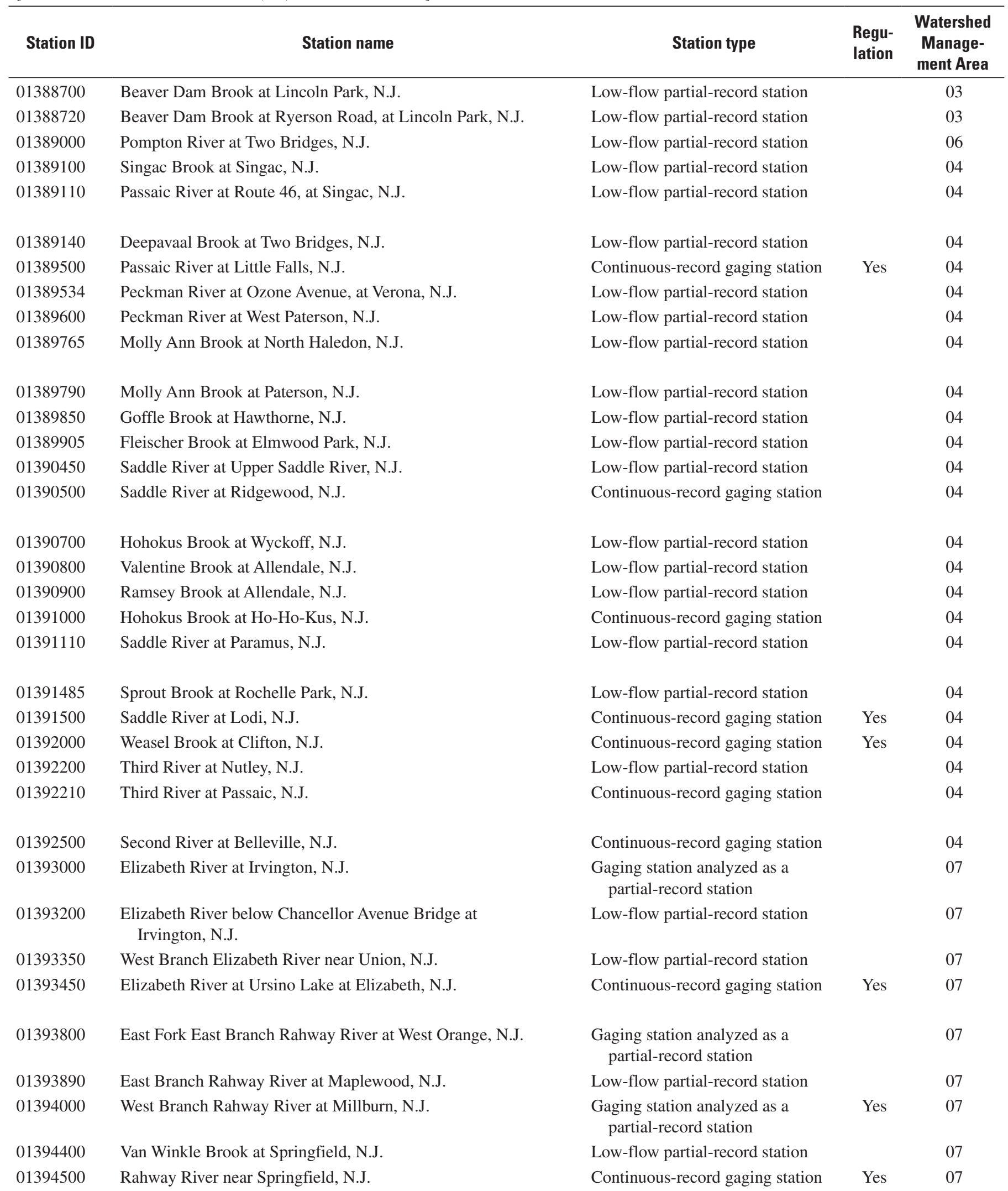


Table 1-1. Index, by station identification number, of selected continuous-record streamflow-gaging stations, low-flow partial-record stations, and gaging stations analyzed as a partial-record stations in New Jersey, New York, and Pennsylvania.-Continued

[Stations are listed in downstream order; ID, identification number]

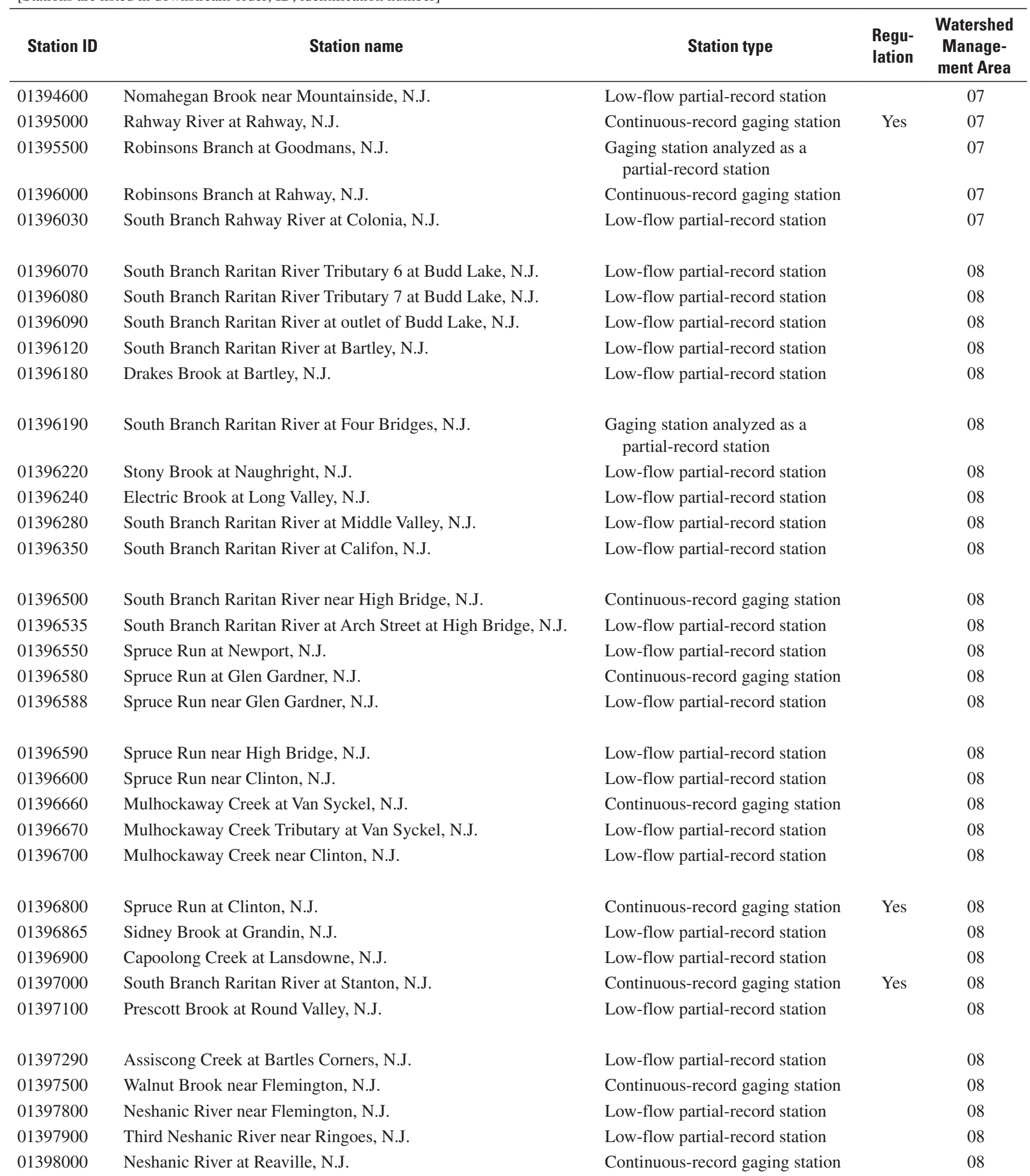


Table 1-1. Index, by station identification number, of selected continuous-record streamflow-gaging stations, low-flow partial-record stations, and gaging stations analyzed as a partial-record stations in New Jersey, New York, and Pennsylvania. - Continued

[Stations are listed in downstream order; ID, identification number]

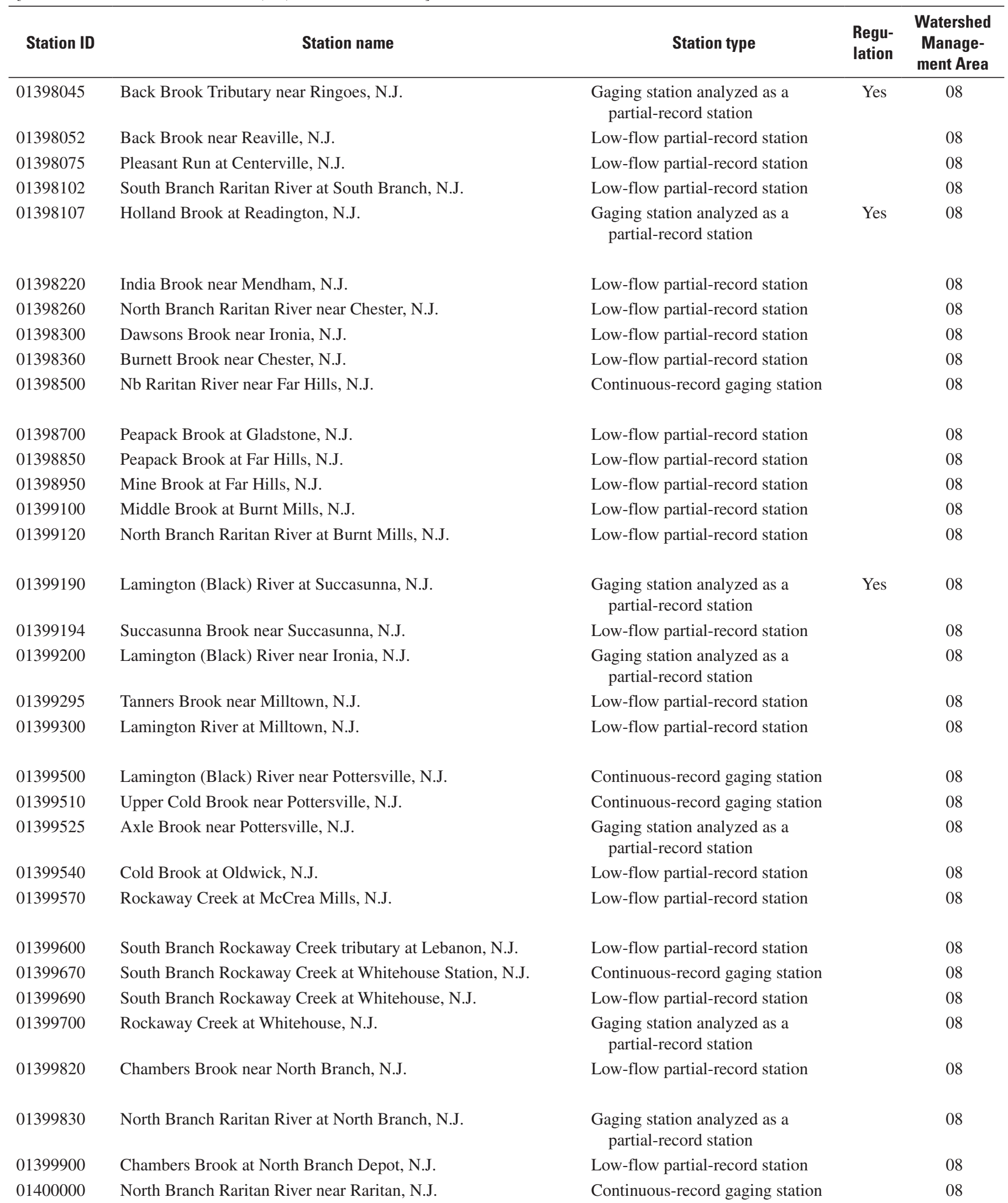


Table 1-1. Index, by station identification number, of selected continuous-record streamflow-gaging stations, low-flow partial-record stations, and gaging stations analyzed as a partial-record stations in New Jersey, New York, and Pennsylvania.-Continued

[Stations are listed in downstream order; ID, identification number]

\begin{tabular}{|c|c|c|c|c|}
\hline Station ID & Station name & Station type & $\begin{array}{l}\text { Regu- } \\
\text { lation }\end{array}$ & $\begin{array}{c}\text { Watershed } \\
\text { Manage- } \\
\text { ment Area }\end{array}$ \\
\hline 01400300 & Peters Brook near Raritan, N.J. & $\begin{array}{l}\text { Gaging station analyzed as a } \\
\text { partial-record station }\end{array}$ & Yes & 10 \\
\hline 01400350 & Macs Brook at Somerville, N.J. & $\begin{array}{l}\text { Gaging station analyzed as a } \\
\text { partial-record station }\end{array}$ & & 10 \\
\hline 01400560 & Millstone River at Applegarth, N.J. & Low-flow partial-record station & & 10 \\
\hline 01400580 & Millstone River at Hightstown, N.J. & Low-flow partial-record station & & 10 \\
\hline 01400593 & Rocky Brook at Hightstown, N.J. & Low-flow partial-record station & & 10 \\
\hline 01400670 & Cranbury Brook at Old Church, N.J. & Low-flow partial-record station & & 10 \\
\hline 01400700 & Cranbury Brook at Cranbury Station, N.J. & Low-flow partial-record station & & 10 \\
\hline 01400725 & Cranbury Brook at Plainsboro, N.J. & Low-flow partial-record station & & 10 \\
\hline 01400730 & Millstone River at Plainsboro, N.J. & $\begin{array}{l}\text { Gaging station analyzed as a } \\
\text { partial-record station }\end{array}$ & & 10 \\
\hline 01400750 & Bear Brook near Hickory Corner, N.J. & Low-flow partial-record station & & 10 \\
\hline 01400770 & Little Bear Brook at Hickory Corner, N.J. & Low-flow partial-record station & & 10 \\
\hline 01400800 & Bear Brook near Grovers Mill, N.J. & Low-flow partial-record station & & 10 \\
\hline 01400947 & Stony Brook at Pennington, N.J. & Low-flow partial-record station & & 10 \\
\hline 01400953 & Honey Branch near Pennington, N.J. & $\begin{array}{l}\text { Gaging station analyzed as a } \\
\text { partial-record station }\end{array}$ & & 10 \\
\hline 01400970 & Honey Branch near Rosedale, N.J. & Low-flow partial-record station & & 10 \\
\hline 01401000 & Stony Brook at Princeton, N.J. & Continuous-record gaging station & & 10 \\
\hline 01401100 & Stony Brook at Clarksville, N.J. & Low-flow partial-record station & & 10 \\
\hline 01401200 & Duck Pond Run at Clarksville, N.J. & Low-flow partial-record station & & 10 \\
\hline 01401301 & Millstone River at Carnegie Lake at Princeton, N.J. & $\begin{array}{l}\text { Gaging station analyzed as a } \\
\text { partial-record station }\end{array}$ & & 10 \\
\hline 01401400 & Heathcote Brook at Kingston, N.J. & Low-flow partial-record station & & 10 \\
\hline 01401500 & Millstone River near Kingston, N.J. & $\begin{array}{l}\text { Gaging station analyzed as a } \\
\text { partial-record station }\end{array}$ & Yes & 10 \\
\hline 01401520 & Beden Brook near Hopewell, N.J. & Low-flow partial-record station & & 10 \\
\hline 01401590 & Rock Brook at Blawenburg, N.J. & Low-flow partial-record station & & 10 \\
\hline
\end{tabular}


Table 1-1. Index, by station identification number, of selected continuous-record streamflow-gaging stations, low-flow partial-record stations, and gaging stations analyzed as a partial-record stations in New Jersey, New York, and Pennsylvania. - Continued

[Stations are listed in downstream order; ID, identification number]

\begin{tabular}{|c|c|c|c|c|}
\hline Station ID & Station name & Station type & $\begin{array}{l}\text { Regu- } \\
\text { lation }\end{array}$ & $\begin{array}{c}\text { Watershed } \\
\text { Manage- } \\
\text { ment Area }\end{array}$ \\
\hline 01401600 & Beden Brook near Rocky Hill, N.J. & Low-flow partial-record station & & 10 \\
\hline 01401650 & Pike Run at Belle Mead, N.J. & Continuous-record gaging station & & 10 \\
\hline 01401700 & Pike Run near Rocky Hill, N.J. & Low-flow partial-record station & & 10 \\
\hline 01401800 & Ten Mile Run near Blackwells Mills, N.J. & Low-flow partial-record station & & 10 \\
\hline 01402000 & Millstone River at Blackwells Mills, N.J. & Continuous-record gaging station & Yes & 10 \\
\hline 01402590 & Royce Brook Tributary at Frankfort, N.J. & $\begin{array}{l}\text { Gaging station analyzed as a } \\
\text { partial-record station }\end{array}$ & & 10 \\
\hline 01402600 & Royce Brook Tributary near Belle Mead, N.J. & Continuous-record gaging station & & 10 \\
\hline 01403100 & East Branch Middle Brook at Martinsville, N.J. & Low-flow partial-record station & & 09 \\
\hline 01403150 & West Branch Middle Brook near Martinsville, N.J. & Continuous-record gaging station & Yes & 09 \\
\hline 01403160 & West Branch Middle Brook near Somerville, N.J. & $\begin{array}{l}\text { Gaging station analyzed as a } \\
\text { partial-record station }\end{array}$ & & 09 \\
\hline 01403330 & Bound Brook at South Plainfield, N.J. & Low-flow partial-record station & & 09 \\
\hline 01403350 & Cedar Brook at South Plainfield, N.J. & Low-flow partial-record station & & 09 \\
\hline 01403385 & Bound Brook at Route 28 at Middlesex, N.J. & Low-flow partial-record station & & 09 \\
\hline 01403395 & Blue Brook at Seeleys Pond Dam near Berkeley Heights, N.J. & Low-flow partial-record station & & 09 \\
\hline 01403400 & Green Brook at Seeley Mills, N.J. & Continuous-record gaging station & & 09 \\
\hline 01404180 & Mill Brook at Highland Park, N.J. & Low-flow partial-record station & & 09 \\
\hline 01404300 & Lawrence Brook at outlet of Davidsons Mill Pond, N.J. & Low-flow partial-record station & & 09 \\
\hline 01404400 & Oakeys Brook near Patricks Corner, N.J. & Low-flow partial-record station & & 09 \\
\hline 01404470 & Ireland Brook at Patricks Corner, N.J. & Low-flow partial-record station & & 09 \\
\hline 01404500 & Lawrence Brook at Patricks Corner, N.J. & $\begin{array}{l}\text { Gaging station analyzed as a } \\
\text { partial-record station }\end{array}$ & & 09 \\
\hline 01404700 & Beaverdam Brook near Patricks Corner, N.J. & Low-flow partial-record station & & 09 \\
\hline 01405000 & Lawrence Brook at Farrington Dam, N.J. & Continuous-record gaging station & Yes & 09 \\
\hline 01405030 & Lawrence Brook at Westons Mills, N.J. & Continuous-record gaging station & Yes & 09 \\
\hline 01405170 & Milford Brook at Englishtown, N.J. & Low-flow partial-record station & & 09 \\
\hline 01405180 & Mcgellairds Brook at Englishtown, N.J. & Low-flow partial-record station & & 09 \\
\hline 01405210 & Pine Brook at Clarks Mills, N.J. & Low-flow partial-record station & & 09 \\
\hline 01405240 & Matchaponix Brook near Englishtown, N.J. & Low-flow partial-record station & & 09 \\
\hline
\end{tabular}


Table 1-1. Index, by station identification number, of selected continuous-record streamflow-gaging stations, low-flow partial-record stations, and gaging stations analyzed as a partial-record stations in New Jersey, New York, and Pennsylvania.-Continued

[Stations are listed in downstream order; ID, identification number]

\begin{tabular}{|c|c|c|c|c|}
\hline Station ID & Station name & Station type & $\begin{array}{l}\text { Regu- } \\
\text { lation }\end{array}$ & $\begin{array}{c}\text { Watershed } \\
\text { Manage- } \\
\text { ment Area }\end{array}$ \\
\hline 01405285 & Barclay Brook near Englishtown, N.J. & Low-flow partial-record station & & 09 \\
\hline 01405290 & Matchaponix Brook at Texas, N.J. & Low-flow partial-record station & & 09 \\
\hline 01405300 & Matchaponix Brook at Spotswood, N.J. & $\begin{array}{l}\text { Gaging station analyzed as a } \\
\text { partial-record station }\end{array}$ & & 09 \\
\hline 01405335 & Manalapan Brook near Manalapan, N.J. & Low-flow partial-record station & & 09 \\
\hline 01405340 & Manalapan Brook at Federal Road near Manalapan, N.J. & Low-flow partial-record station & & 09 \\
\hline 01405400 & Manalapan Brook at Spotswood, N.J. & Continuous-record gaging station & Yes & 09 \\
\hline 01405435 & Cedar Brook at Spotswood, N.J. & Low-flow partial-record station & & 09 \\
\hline 01405500 & South River at Old Bridge, N.J. & Continuous-record gaging station & Yes & 09 \\
\hline 01406000 & Deep Run near Browntown, N.J. & $\begin{array}{l}\text { Gaging station analyzed as a } \\
\text { partial-record station }\end{array}$ & & 09 \\
\hline 01406040 & Deep Run at Route 516, near Old Bridge, N.J. & Low-flow partial-record station & & 09 \\
\hline 01406050 & Deep Run at Old Bridge, N.J. & $\begin{array}{l}\text { Gaging station analyzed as a } \\
\text { partial-record station }\end{array}$ & & 09 \\
\hline 01406500 & Tennent Brook near Browntown, N.J. & $\begin{array}{l}\text { Gaging station analyzed as a } \\
\text { partial-record station }\end{array}$ & & 09 \\
\hline 01407000 & Matawan Creek at Matawan, N.J. & Continuous-record gaging station & Yes & 12 \\
\hline 01407200 & Hop Brook at Holmdel, N.J. & Low-flow partial-record station & & 12 \\
\hline 01407250 & Willow Brook at Holmdel, N.J. & Low-flow partial-record station & & 12 \\
\hline 01407300 & Big Brook at Vanderburg, N.J. & Low-flow partial-record station & & 12 \\
\hline 01407400 & Yellow Brook at Colts Neck, N.J. & Low-flow partial-record station & & 12 \\
\hline 01407450 & Mine Brook at Colts Neck, N.J. & Low-flow partial-record station & & 12 \\
\hline 01407500 & Swimming River near Red Bank, N.J. & Continuous-record gaging station & Yes & 12 \\
\hline 01407532 & Poricy Brook at Red Bank, N.J. & Low-flow partial-record station & & 12 \\
\hline 01407618 & Whale Pond Brook near Oakhurst, N.J. & Low-flow partial-record station & & 12 \\
\hline 01407628 & Poplar Brook near Deal, N.J. & Low-flow partial-record station & & 12 \\
\hline 01407636 & Harvey Brook at West Allenhurst, N.J. & Low-flow partial-record station & & 12 \\
\hline 01407700 & Shark River at Glendola, N.J. & Low-flow partial-record station & & 12 \\
\hline 01407705 & Shark River near Neptune City, N.J. & Continuous-record gaging station & Yes & 12 \\
\hline 01407755 & Jumping Brook above reservior, near Neptune City, N.J. & Low-flow partial-record station & & 12 \\
\hline
\end{tabular}


Table 1-1. Index, by station identification number, of selected continuous-record streamflow-gaging stations, low-flow partial-record stations, and gaging stations analyzed as a partial-record stations in New Jersey, New York, and Pennsylvania. - Continued

[Stations are listed in downstream order; ID, identification number]

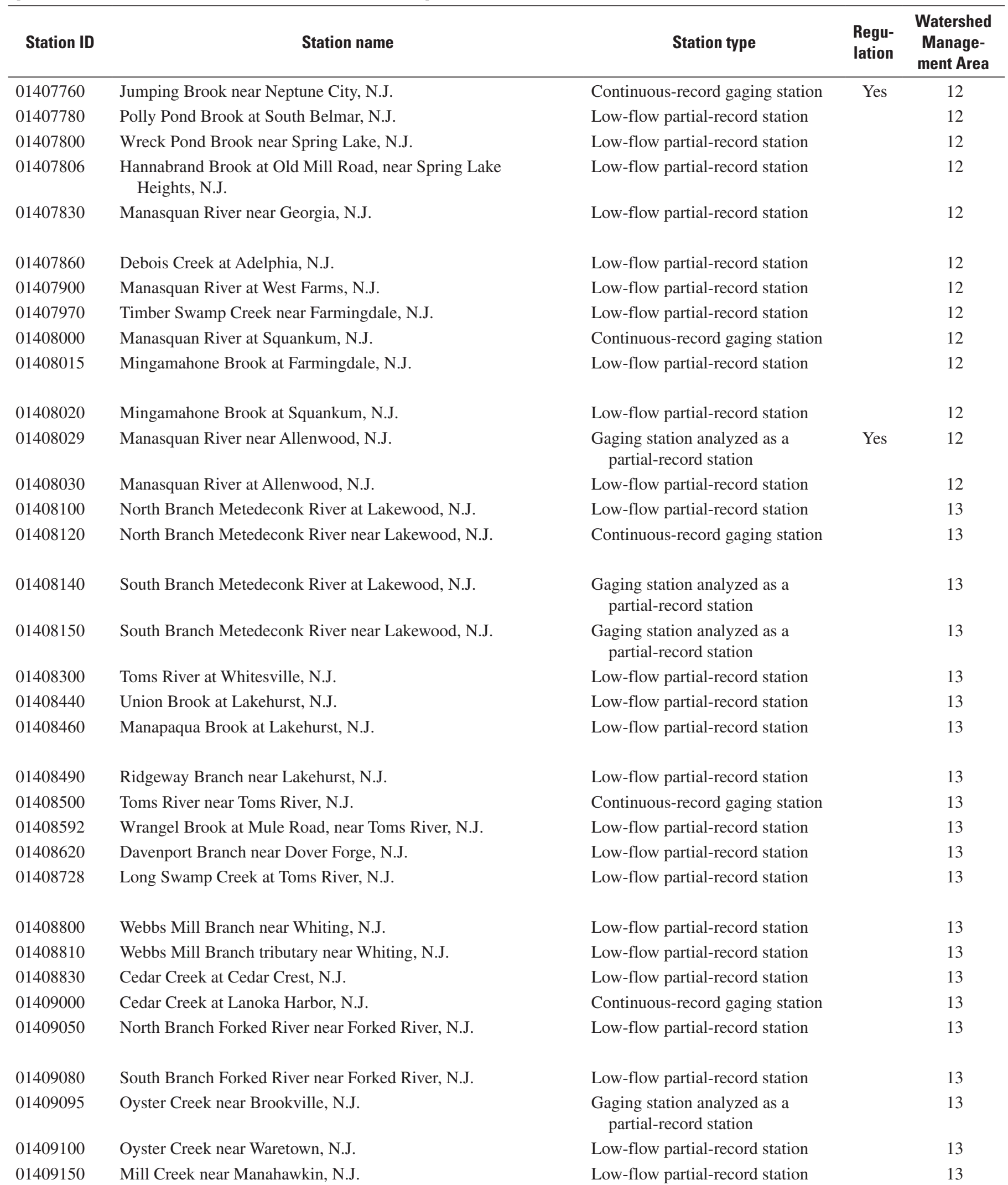


Table 1-1. Index, by station identification number, of selected continuous-record streamflow-gaging stations, low-flow partial-record stations, and gaging stations analyzed as a partial-record stations in New Jersey, New York, and Pennsylvania.—Continued

[Stations are listed in downstream order; ID, identification number]

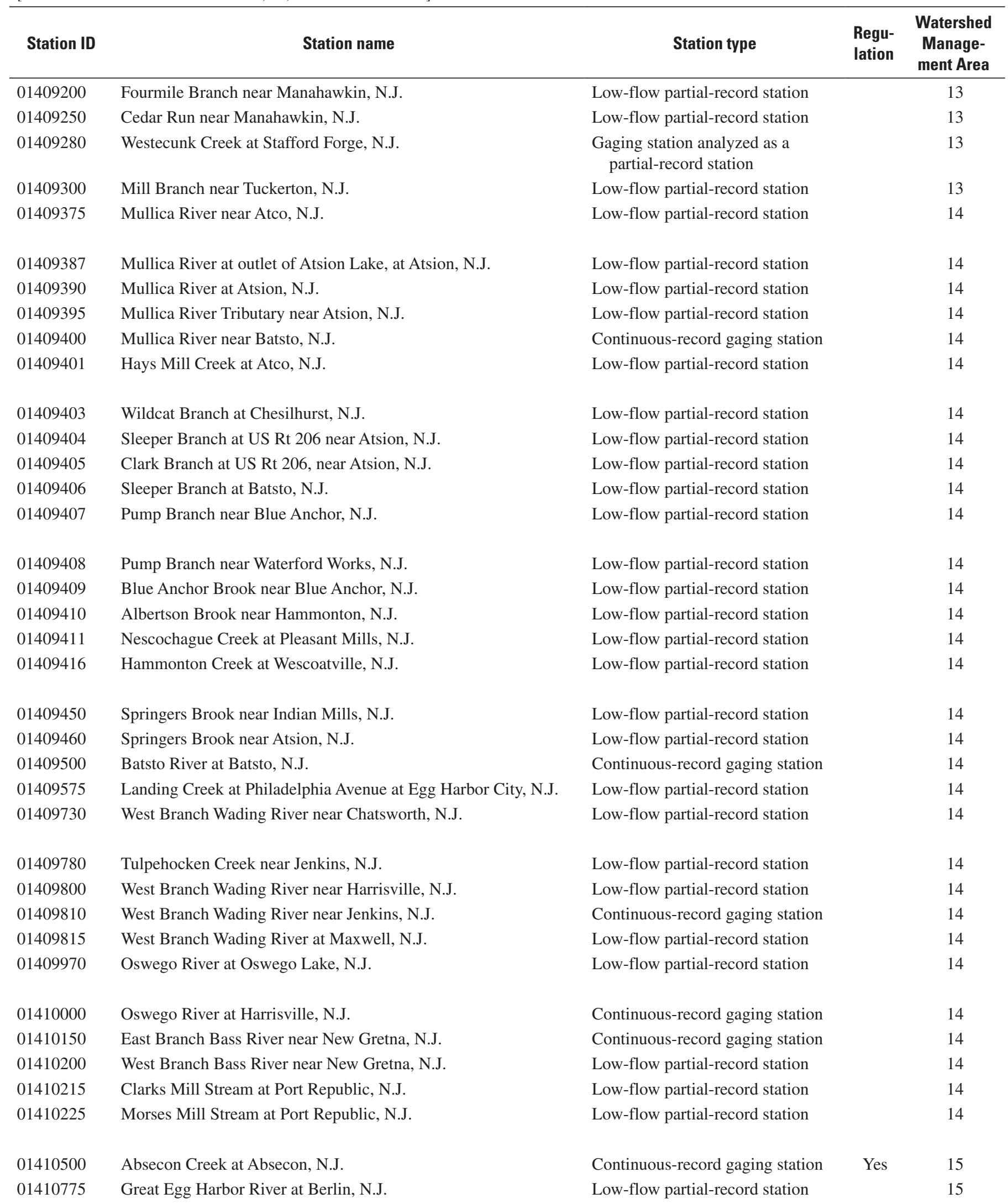


Table 1-1. Index, by station identification number, of selected continuous-record streamflow-gaging stations, low-flow partial-record stations, and gaging stations analyzed as a partial-record stations in New Jersey, New York, and Pennsylvania.-Continued

[Stations are listed in downstream order; ID, identification number]

$\begin{array}{ccc}\text { Station ID } & \text { Station name } & \text { Watershed } \\
\text { Manage- } \\
\text { ment Area }\end{array} \quad \begin{gathered}\text { Segu- } \\
\text { Iation type }\end{gathered} \quad$\begin{tabular}{c} 
Station \\
\hline
\end{tabular}

01410784 Great Egg Harbor River near Sicklerville, N.J.

01410787 Great Egg Harbor River Tributary at Sicklerville, N.J.

$01410800 \quad$ Fourmile Branch near Williamstown, N.J.

01410803 Fourmile Branch at Winslow Crossing, N.J.

$01410810 \quad$ Fourmile Branch at New Brooklyn, N.J.

01410820 Great Egg Harbor River near Blue Anchor, N.J.

01410855 Squankum Brook above sewage treatment plant, at Williamstown, N.J.

01410865 Squankum Branch at Malaga Road, near Williamstown, N.J.

01411000 Great Egg Harbor River at Folsom, N.J.

01411020 Penny Pot Stream near Folsom, N.J.

01411035 Hospitality Branch at Blue Bell Road, near Cecil, N.J.

$01411040 \quad$ Hospitality Branch near Cecil, N.J.

01411042 Whitehall Branch near Cecil, N.J.

01411047 Whitehall Branch below Victory Lakes, near Cecil, N.J.

01411053 Hospitality Branch at Berryland, N.J.

01411110 Great Egg Harbor River at Weymouth, N.J.

01411140 Deep Run at Weymouth, N.J.

01411170 Great Egg Harbor River at Mays Landing, N.J.

01411196 Babcock Creek near Mays Landing, N.J.

$01411200 \quad$ Babcock Creek at Mays Landing, N.J.

$01411220 \quad$ South River near Belcoville, N.J.

$01411250 \quad$ English Creek near Scullville, N.J.

01411299 Tarkiln Brook near Head of River, N.J.

01411300 Tuckahoe River at Head of River, N.J.

01411302 Mill Creek near Steelmantown, N.J.

01411305 Mill Branch near Northfield, N.J.

01411351 Mill Creek at outlet Magnolia Lake at Ocean View, N.J.

01411388 Mill Creek at Cold Spring, N.J.

$01411400 \quad$ Fishing Creek at Rio Grande, N.J.

01411404 Green Creek at Green Creek, N.J.

01411408 Dias Creek near Cape May Court House, N.J.

01411410 Bidwell Creek tributary near Cape May Court House, N.J.

01411412 Bidwell Creek tributary 2 near Cape May Court House, N.J.

01411418 Goshen Creek at Goshen, N.J.
Gaging station analyzed as a partial-record station

Gaging station analyzed as a partial-record station

Low-flow partial-record station $\quad 15$

Low-flow partial-record station $\quad 15$

Gaging station analyzed as a $\quad 15$

partial-record station

Gaging station analyzed as a partial-record station

Low-flow partial-record station $\quad 15$

Low-flow partial-record station $\quad 15$

Continuous-record gaging station $\quad 15$

Low-flow partial-record station $\quad 15$

Low-flow partial-record station $\quad 15$

Low-flow partial-record station $\quad 15$

Low-flow partial-record station $\quad 15$

Low-flow partial-record station $\quad 15$

Low-flow partial-record station $\quad 15$

Low-flow partial-record station $\quad 15$

Low-flow partial-record station $\quad 15$

Low-flow partial-record station $\quad 15$

Low-flow partial-record station $\quad 15$

Low-flow partial-record station $\quad 15$

Low-flow partial-record station $\quad 15$

Low-flow partial-record station $\quad 15$

Low-flow partial-record station $\quad 15$

Continuous-record gaging station $\quad 15$

Low-flow partial-record station $\quad 15$

Low-flow partial-record station $\quad 15$

Low-flow partial-record station $\quad 16$

Low-flow partial-record station $\quad 16$

Low-flow partial-record station $\quad 16$

Low-flow partial-record station $\quad 16$

Low-flow partial-record station $\quad 16$

Low-flow partial-record station $\quad 16$

Low-flow partial-record station $\quad 16$

Low-flow partial-record station $\quad 16$ 
Table 1-1. Index, by station identification number, of selected continuous-record streamflow-gaging stations, low-flow partial-record stations, and gaging stations analyzed as a partial-record stations in New Jersey, New York, and Pennsylvania.-Continued

[Stations are listed in downstream order; ID, identification number]

\begin{tabular}{|c|c|c|c|c|}
\hline Station ID & Station name & Station type & $\begin{array}{l}\text { Regu- } \\
\text { lation }\end{array}$ & $\begin{array}{c}\text { Watershed } \\
\text { Manage- } \\
\text { ment Area }\end{array}$ \\
\hline 01411428 & Dennis Creek Tributary 2 at Dennisville, N.J. & Low-flow partial-record station & & 16 \\
\hline 01411430 & Sluice Creek at Clermont, N.J. & Low-flow partial-record station & & 16 \\
\hline 01411434 & Sluice Creek at outlet Clint Mill Pond at South Dennis, N.J. & Low-flow partial-record station & & 16 \\
\hline 01411438 & Dennis Creek Tributary 1 near North Dennis, N.J. & Low-flow partial-record station & & 16 \\
\hline 01411444 & West Creek near Leesburg, N.J. & Low-flow partial-record station & & 16 \\
\hline 01411445 & West Creek near Eldora, N.J. & Low-flow partial-record station & & 16 \\
\hline 01411450 & Still Run at Aura, N.J. & Low-flow partial-record station & & 17 \\
\hline 01411456 & Little Ease Run near Clayton, N.J. & $\begin{array}{l}\text { Gaging station analyzed as a } \\
\text { partial-record station }\end{array}$ & & 17 \\
\hline 01411461 & Scotland Run at Fries Mill, N.J. & Low-flow partial-record station & & 17 \\
\hline 01411462 & Scotland Run at Franklinville, N.J. & Low-flow partial-record station & & 17 \\
\hline 01411466 & Indian Brook near Malaga, N.J. & Low-flow partial-record station & & 17 \\
\hline 01411485 & Maurice River at Brotmanville, N.J. & $\begin{array}{l}\text { Gaging station analyzed as a } \\
\text { partial-record station }\end{array}$ & & 17 \\
\hline 01411495 & Blackwater Branch at Norma, N.J. & $\begin{array}{l}\text { Gaging station analyzed as a } \\
\text { partial-record station }\end{array}$ & & 17 \\
\hline 01411500 & Maurice River at Norma, N.J. & Continuous-record gaging station & & 17 \\
\hline 01411650 & Muddy Run near Elmer, N.J. & Low-flow partial-record station & & 17 \\
\hline 01411880 & Maurice River at Sharp Street at Millville, N.J. & Low-flow partial-record station & & 17 \\
\hline 01411950 & Buckshutem Creek near Laurel Lake, N.J. & Low-flow partial-record station & & 17 \\
\hline 01411955 & Gravelly Run at Laurel Lake, N.J. & Low-flow partial-record station & & 17 \\
\hline 01412000 & Menantico Creek near Millville, N.J. & Continuous-record gaging station & & 17 \\
\hline 01412100 & Manumuskin River near Manumuskin, N.J. & Low-flow partial-record station & & 17 \\
\hline 01412120 & Muskee Creek near Port Elizabeth, N.J. & Low-flow partial-record station & & 17 \\
\hline 01412405 & Cohansey River near Beals Mill, N.J. & Low-flow partial-record station & & 17 \\
\hline 01412500 & West Branch Cohansey River at Seeley, N.J. & $\begin{array}{l}\text { Gaging station analyzed as a } \\
\text { partial-record station }\end{array}$ & Yes & 17 \\
\hline 01412800 & Cohansey River at Seeley, N.J. & $\begin{array}{l}\text { Gaging station analyzed as a } \\
\text { partial-record station }\end{array}$ & & 17 \\
\hline 01413010 & Barrett Run near Bridgeton, N.J. & Low-flow partial-record station & & 17 \\
\hline 01413020 & Indian Fields Branch at Bridgeton, N.J. & Low-flow partial-record station & & 17 \\
\hline
\end{tabular}


Table 1-1. Index, by station identification number, of selected continuous-record streamflow-gaging stations, low-flow partial-record stations, and gaging stations analyzed as a partial-record stations in New Jersey, New York, and Pennsylvania.-Continued

[Stations are listed in downstream order; ID, identification number]

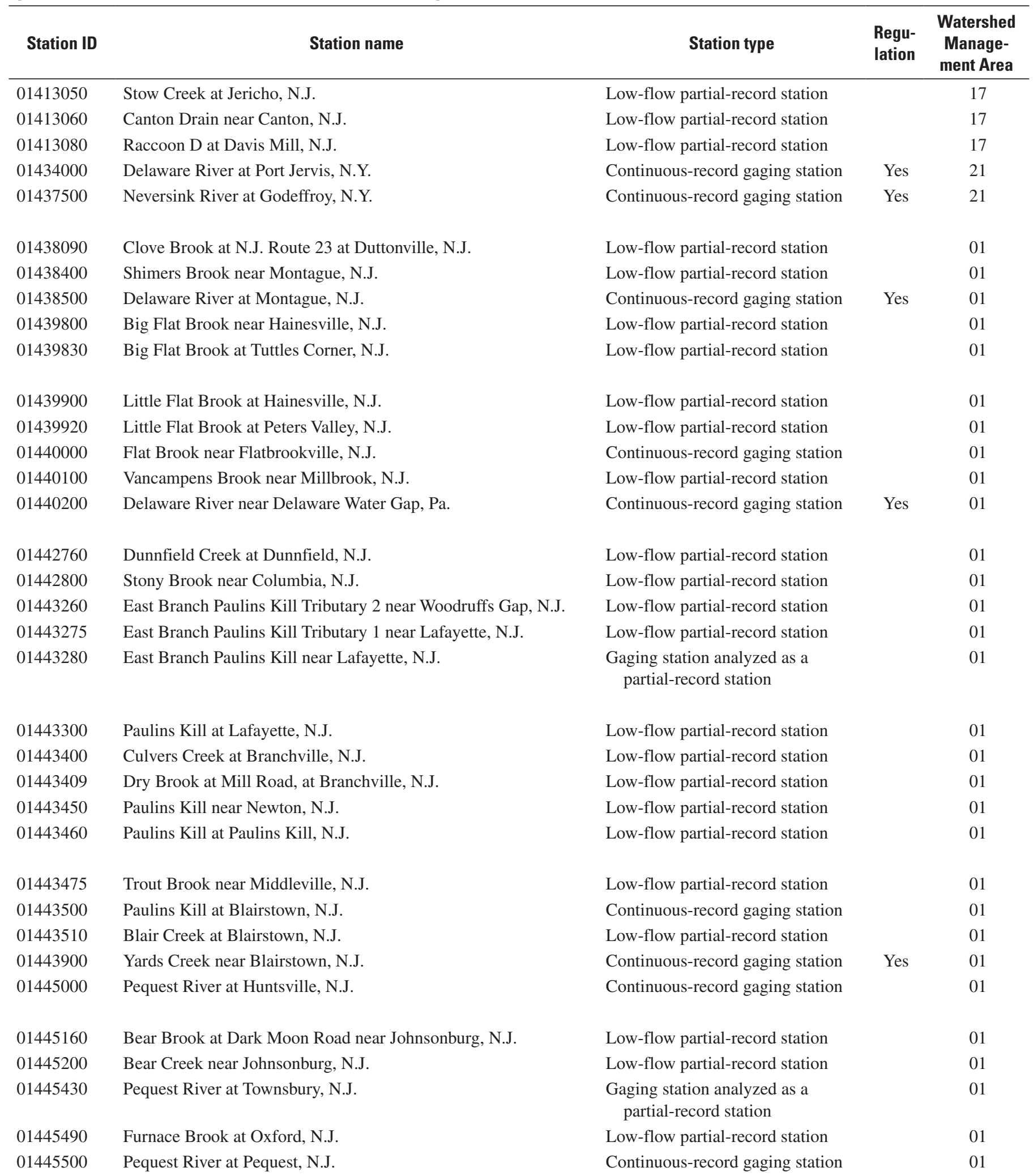


Table 1-1. Index, by station identification number, of selected continuous-record streamflow-gaging stations, low-flow partial-record stations, and gaging stations analyzed as a partial-record stations in New Jersey, New York, and Pennsylvania.-Continued

[Stations are listed in downstream order; ID, identification number]

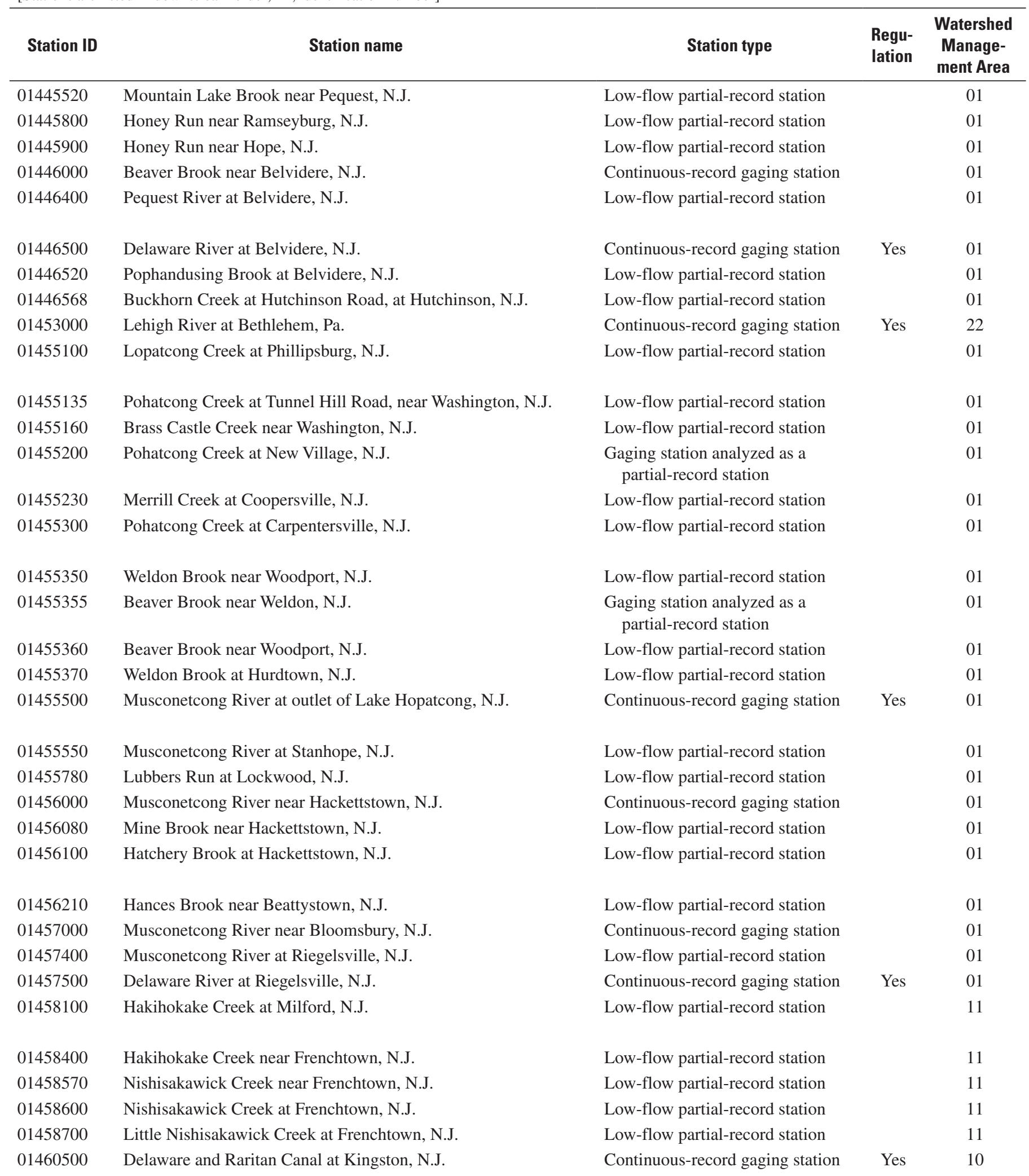


Table 1-1. Index, by station identification number, of selected continuous-record streamflow-gaging stations, low-flow partial-record stations, and gaging stations analyzed as a partial-record stations in New Jersey, New York, and Pennsylvania.-Continued

[Stations are listed in downstream order; ID, identification number]

\begin{tabular}{|c|c|c|c|c|}
\hline Station ID & Station name & Station type & $\begin{array}{l}\text { Regu- } \\
\text { lation }\end{array}$ & $\begin{array}{c}\text { Watershed } \\
\text { Manage- } \\
\text { ment Area }\end{array}$ \\
\hline 01460900 & Lockatong Creek near Raven Rock, N.J. & Low-flow partial-record station & & 11 \\
\hline 01461300 & Wickecheoke Creek at Stockton, N.J. & Low-flow partial-record station & & 11 \\
\hline 01461900 & Alexauken Creek near Lambertville, N.J. & Low-flow partial-record station & & 11 \\
\hline 01462200 & Moores Creek near Titusville, N.J. & Low-flow partial-record station & & 11 \\
\hline 01463500 & Delaware River at Trenton, N.J. & Continuous-record gaging station & Yes & 11 \\
\hline 01463620 & Assunpink Creek near Clarksville, N.J. & $\begin{array}{l}\text { Gaging station analyzed as a } \\
\text { partial-record station }\end{array}$ & & 11 \\
\hline 01463650 & Shipetaukin Creek at Lawrenceville, N.J. & Low-flow partial-record station & & 11 \\
\hline 01463750 & Shabakunk Creek at Ewingville, N.J. & Low-flow partial-record station & & 11 \\
\hline 01463790 & West Branch Shabakunk Creek near Ewingville, N.J. & Low-flow partial-record station & & 11 \\
\hline 01463830 & Miry Run at Robbinsville, N.J. & Low-flow partial-record station & & 11 \\
\hline 01463860 & Miry Run at Mercerville, N.J. & Low-flow partial-record station & & 11 \\
\hline 01463980 & Pond Run at Trenton, N.J. & Low-flow partial-record station & & 11 \\
\hline 01464000 & Assunpink Creek at Trenton, N.J. & Continuous-record gaging station & Yes & 11 \\
\hline 01464300 & Crosswicks Creek near Cookstown, N.J. & Low-flow partial-record station & & 20 \\
\hline 01464380 & North Run at Cookstown, N.J. & Low-flow partial-record station & & 20 \\
\hline 01464525 & Thorton Creek at Bordentown,, N.J. & $\begin{array}{l}\text { Gaging station analyzed as a } \\
\text { partial-record station }\end{array}$ & & 20 \\
\hline 01464530 & Blacks Creek at Mansfield Sqaure, N.J. & Low-flow partial-record station & & 20 \\
\hline 01464540 & Crafts Creek at Hedding, N.J. & Low-flow partial-record station & & 20 \\
\hline 01464580 & Assiscunk Creek at Columbus, N.J. & Low-flow partial-record station & & 20 \\
\hline 01464590 & Assiscunk Creek near Burlington, N.J. & Low-flow partial-record station & & 20 \\
\hline 01465847 & Jade Run at Vincentown, N.J. & Low-flow partial-record station & & 19 \\
\hline 01465850 & South Branch Rancocas Creek at Vincentown, N.J. & $\begin{array}{l}\text { Gaging station analyzed as a } \\
\text { partial-record station }\end{array}$ & & 19 \\
\hline 01465865 & Barton Run at Tuckerton Road, near Medford, N.J. & Low-flow partial-record station & & 19 \\
\hline 01465880 & Southwest Branch Rancocas Creek at Medford, N.J. & Low-flow partial-record station & & 19 \\
\hline 01465884 & Sharps Run at Route 541 at Medford, N.J. & Low-flow partial-record station & & 19 \\
\hline 01465898 & Little Creek near Lumberton, N.J. & Low-flow partial-record station & & 19 \\
\hline 01465900 & Southwest Branch Rancocas at Eayerstown, N.J. & Low-flow partial-record station & & 19 \\
\hline
\end{tabular}


Table 1-1. Index, by station identification number, of selected continuous-record streamflow-gaging stations, low-flow partial-record stations, and gaging stations analyzed as a partial-record stations in New Jersey, New York, and Pennsylvania.—Continued

[Stations are listed in downstream order; ID, identification number]

\begin{tabular}{|c|c|c|c|c|}
\hline Station ID & Station name & Station type & $\begin{array}{l}\text { Regu- } \\
\text { lation }\end{array}$ & $\begin{array}{l}\text { Watershed } \\
\text { Manage- } \\
\text { ment Area }\end{array}$ \\
\hline 01466000 & $\begin{array}{l}\text { Middle Branch Mount Misery Brook in Lebanon State } \\
\text { Forest, N.J. }\end{array}$ & $\begin{array}{l}\text { Gaging station analyzed as a } \\
\text { partial-record station }\end{array}$ & & 19 \\
\hline 01466500 & Mcdonalds Branch in Lebanon State Forest, N.J. & Continuous-record gaging station & & 19 \\
\hline 01467000 & North Branch Rancocas Creek at Pemberton, N.J. & Continuous-record gaging station & & 19 \\
\hline 01467005 & $\begin{array}{l}\text { North Branch Rancocas Creek at Iron Works Park, at } \\
\text { Mount Holly, N.J. }\end{array}$ & Low-flow partial-record station & & 19 \\
\hline 01467021 & Mill Creek at Levitt Parkway at Willingboro, N.J. & $\begin{array}{l}\text { Gaging station analyzed as a } \\
\text { partial-record station }\end{array}$ & & 19 \\
\hline 01467057 & Pompeston Creek at Cinnaminson, N.J. & Low-flow partial-record station & & 18 \\
\hline 01467070 & North Branch Pennsauken Creek at Maple Shade, N.J. & Low-flow partial-record station & & 18 \\
\hline 01467080 & South Branch Pennsauken Creek at Maple Shade, N.J. & Low-flow partial-record station & & 18 \\
\hline 01467081 & South Branch Pennsauken Creek at Cherry Hill, N.J. & Continuous-record gaging station & & 18 \\
\hline 01467130 & Cooper River at Kirkwood, N.J. & Low-flow partial-record station & & 18 \\
\hline 01467315 & $\begin{array}{l}\text { South Branch Newton Creek at Glover Av at Haddon } \\
\text { Heights, N.J. }\end{array}$ & Low-flow partial-record station & & 18 \\
\hline 01467317 & South Branch Newton Creek at Haddon Heights, N.J. & Low-flow partial-record station & & 18 \\
\hline 01467329 & South Branch Big Timber Creek at Blackwood Terrace, N.J. & Low-flow partial-record station & & 18 \\
\hline 01467330 & South Branch Big Timber Creek at Blackwood, N.J. & Low-flow partial-record station & & 18 \\
\hline 01467350 & North Branch Big Timber Creek at Laurel Springs, N.J. & Low-flow partial-record station & & 18 \\
\hline 01474500 & Schuylkill River at Philadelphia, Pa. & Continuous-record gaging station & Yes & 26 \\
\hline 01474950 & Mantua Creek at Glassboro, N.J. & Low-flow partial-record station & & 18 \\
\hline 01474970 & Mantua Creek at Greentree Road, at Glassboro, N.J. & Low-flow partial-record station & & 18 \\
\hline 01475000 & Mantua Creek at Pitman, N.J. & Continuous-record gaging station & & 18 \\
\hline 01475020 & Mantua Creek at Sewell, N.J. & Low-flow partial-record station & & 18 \\
\hline 01476600 & Still Run near Mickleton, N.J. & $\begin{array}{l}\text { Gaging station analyzed as a } \\
\text { partial-record station }\end{array}$ & & 18 \\
\hline 01476640 & Pargey Creek at Swedesboro Avenue at Repaupo, N.J. & Low-flow partial-record station & & 18 \\
\hline
\end{tabular}


Table 1-1. Index, by station identification number, of selected continuous-record streamflow-gaging stations, low-flow partial-record stations, and gaging stations analyzed as a partial-record stations in New Jersey, New York, and Pennsylvania.-Continued

[Stations are listed in downstream order; ID, identification number]

\begin{tabular}{|c|c|c|c|c|}
\hline Station ID & Station name & Station type & $\begin{array}{l}\text { Regu- } \\
\text { lation }\end{array}$ & $\begin{array}{c}\text { Watershed } \\
\text { Manage- } \\
\text { ment Area }\end{array}$ \\
\hline 01477100 & Raccoon Creek near Mullica Hill, N.J. & Low-flow partial-record station & & 18 \\
\hline 01477110 & Raccoon Creek at Mullica Hill, N.J. & Low-flow partial-record station & & 18 \\
\hline 01477118 & South Branch Raccoon Creek near Mullica Hill, N.J. & Low-flow partial-record station & & 18 \\
\hline 01477120 & Raccoon Creek near Swedesboro, N.J. & Continuous-record gaging station & & 18 \\
\hline 01477510 & Oldmans Creek at Porches Mill, N.J. & Low-flow partial-record station & & 18 \\
\hline 01482500 & Salem River at Woodstown, N.J. & Continuous-record gaging station & Yes & 17 \\
\hline 01482510 & Nichomus Run near Woodstown, N.J. & Low-flow partial-record station & & 17 \\
\hline 01482520 & Salem River at Sharptown, N.J. & Low-flow partial-record station & & 17 \\
\hline 01482950 & Cedar Brook near Alloway, N.J. & Low-flow partial-record station & & 17 \\
\hline 01483000 & Alloway Creek at Alloway, N.J. & Continuous-record gaging station & Yes & 17 \\
\hline 01483010 & Deep Run near Alloway, N.J. & Low-flow partial-record station & & 17 \\
\hline 0140940200 & Hays Mill Creek near Chesilhurst, N.J. & Low-flow partial-record station & & 14 \\
\hline 0140940250 & Cooper Branch near Chesilhurst, N.J. & Low-flow partial-record station & & 14 \\
\hline 0140940310 & Wildcat Branch near Chesilhurst, N.J. & Low-flow partial-record station & & 14 \\
\hline 0140940360 & Sleeper Branch above diversion, near Atsion, N.J. & Low-flow partial-record station & & 14 \\
\hline 0140940370 & Sleeper Branch near Atsion, N.J. & Low-flow partial-record station & & 14 \\
\hline 0140940480 & Clark Branch near Atsion, N.J. & Low-flow partial-record station & & 14 \\
\hline
\end{tabular}


Table 1-2. Index, by station name, of selected continuous-record streamflow-gaging stations, low-flow partial-record stations, and gaging stations analyzed as a partial-record stations in New Jersey, New York, and Pennsylvania.

[Stations are listed in downstream order; ID, identification number]

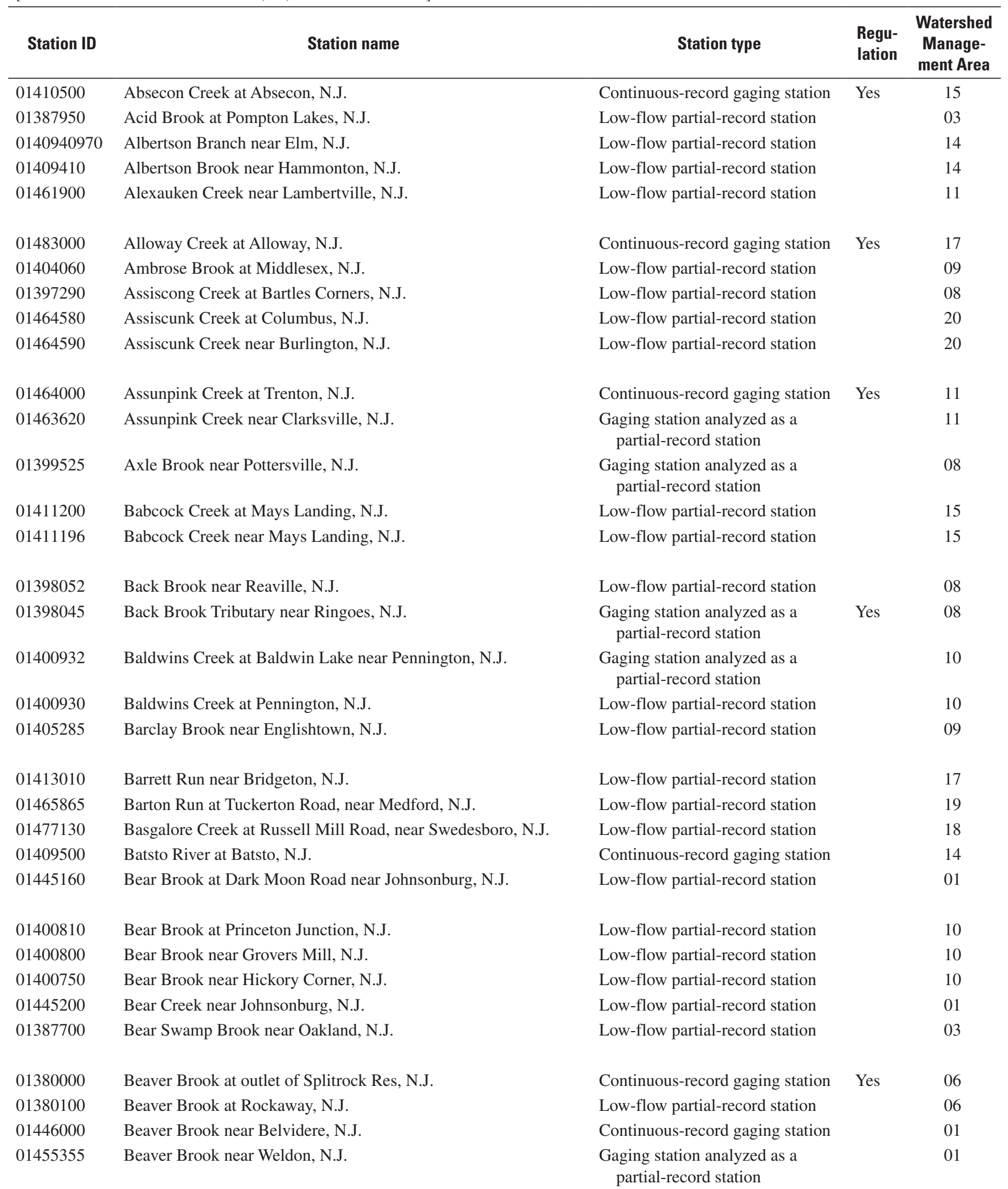


Table 1-2. Index, by station name, of selected continuous-record streamflow-gaging stations, low-flow partial-record stations, and gaging stations analyzed as a partial-record stations in New Jersey, New York, and Pennsylvania.-Continued

[Stations are listed in downstream order; ID, identification number]

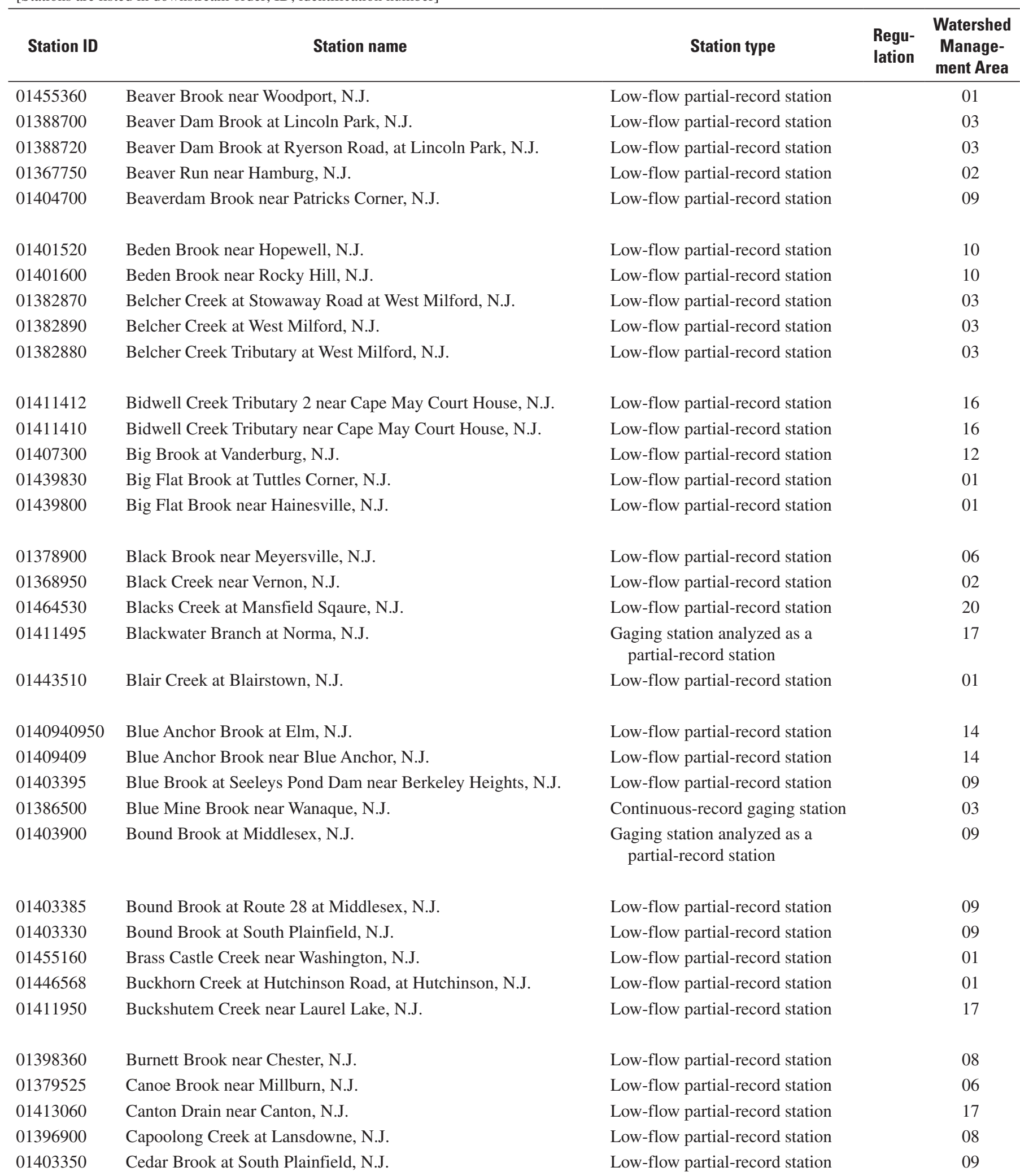


Table 1-2. Index, by station name, of selected continuous-record streamflow-gaging stations, low-flow partial-record stations, and gaging stations analyzed as a partial-record stations in New Jersey, New York, and Pennsylvania.-Continued

[Stations are listed in downstream order; ID, identification number]

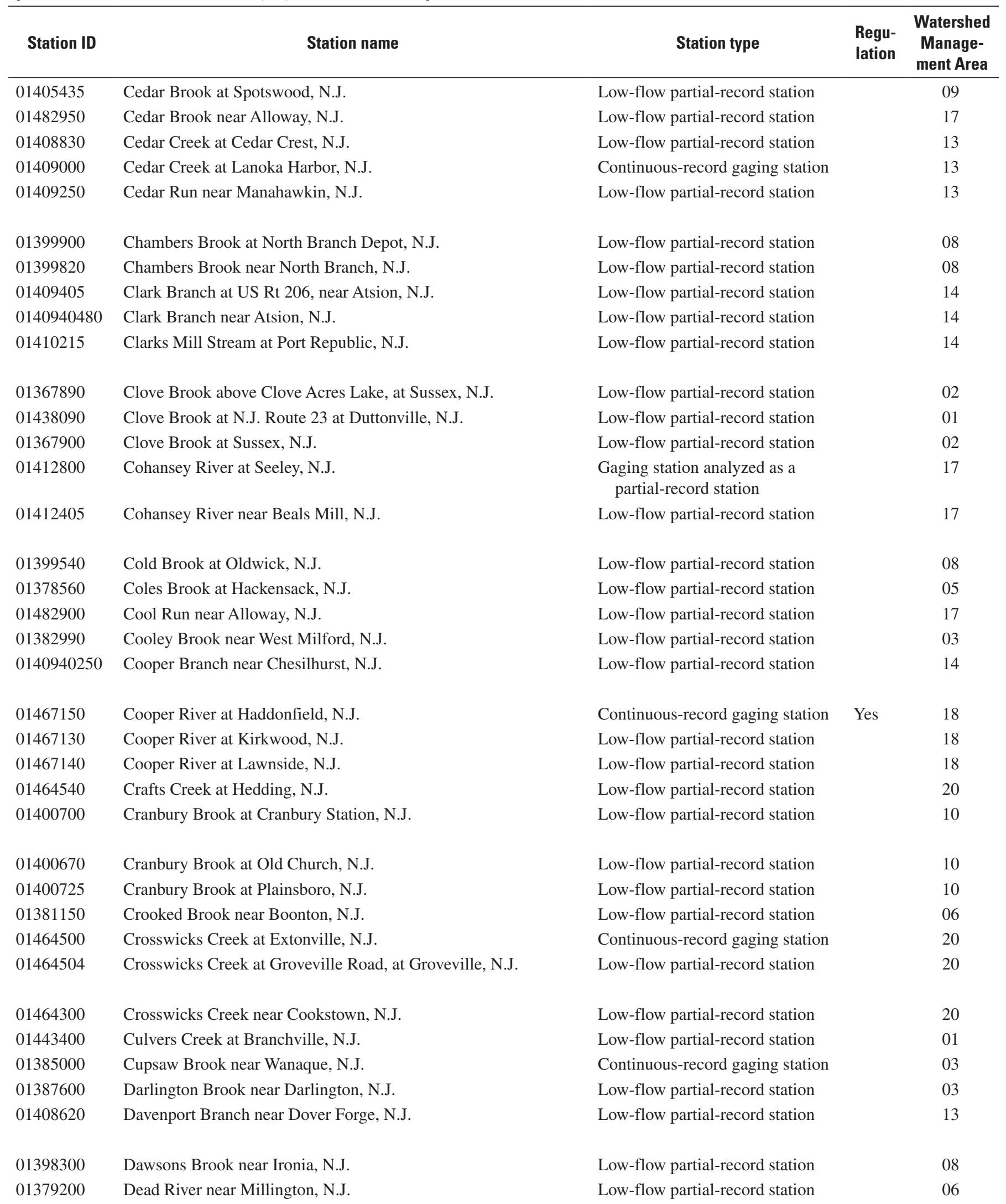


Table 1-2. Index, by station name, of selected continuous-record streamflow-gaging stations, low-flow partial-record stations, and gaging stations analyzed as a partial-record stations in New Jersey, New York, and Pennsylvania.—Continued

[Stations are listed in downstream order; ID, identification number]

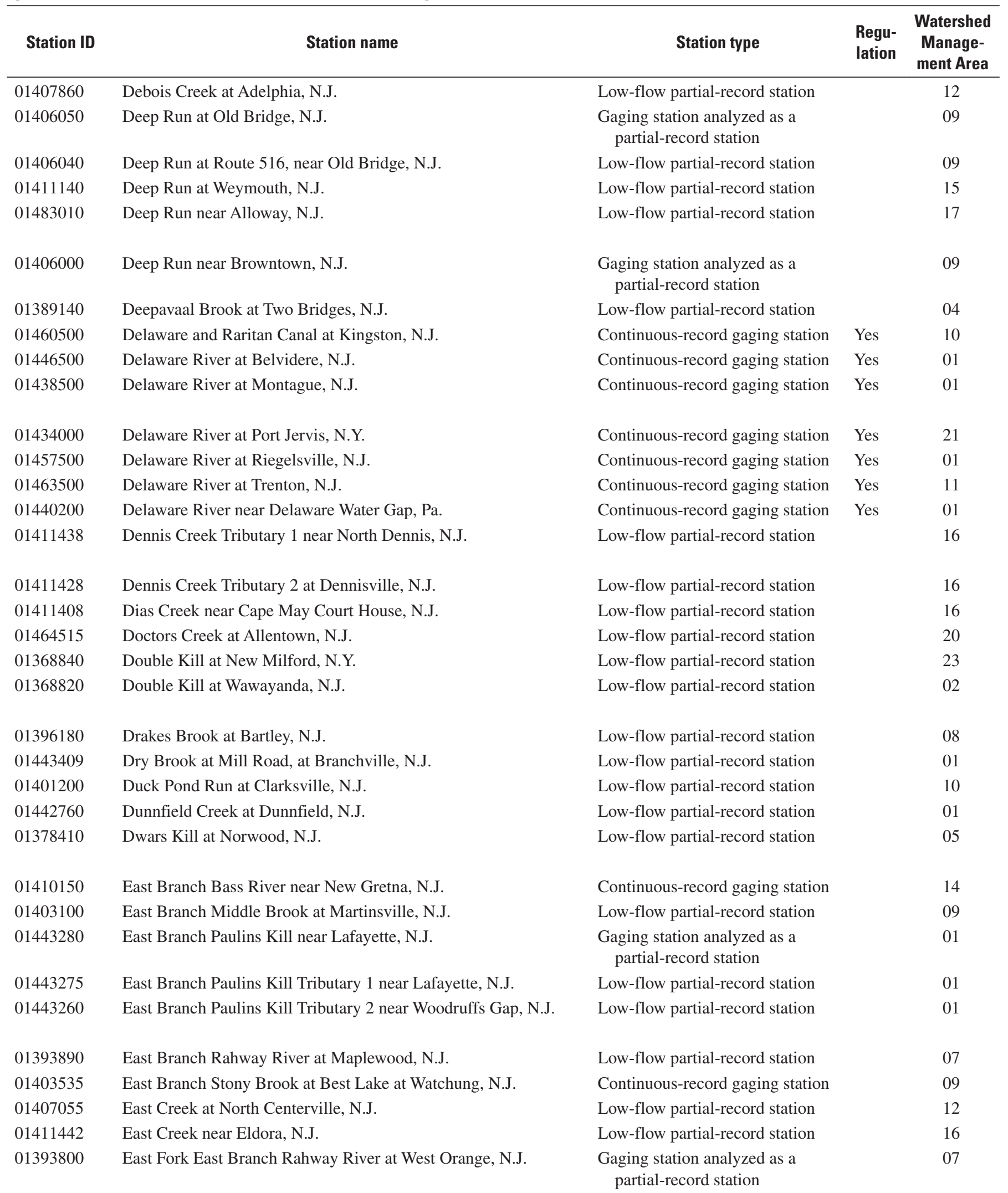


Table 1-2. Index, by station name, of selected continuous-record streamflow-gaging stations, low-flow partial-record stations, and gaging stations analyzed as a partial-record stations in New Jersey, New York, and Pennsylvania.-Continued

[Stations are listed in downstream order; ID, identification number]

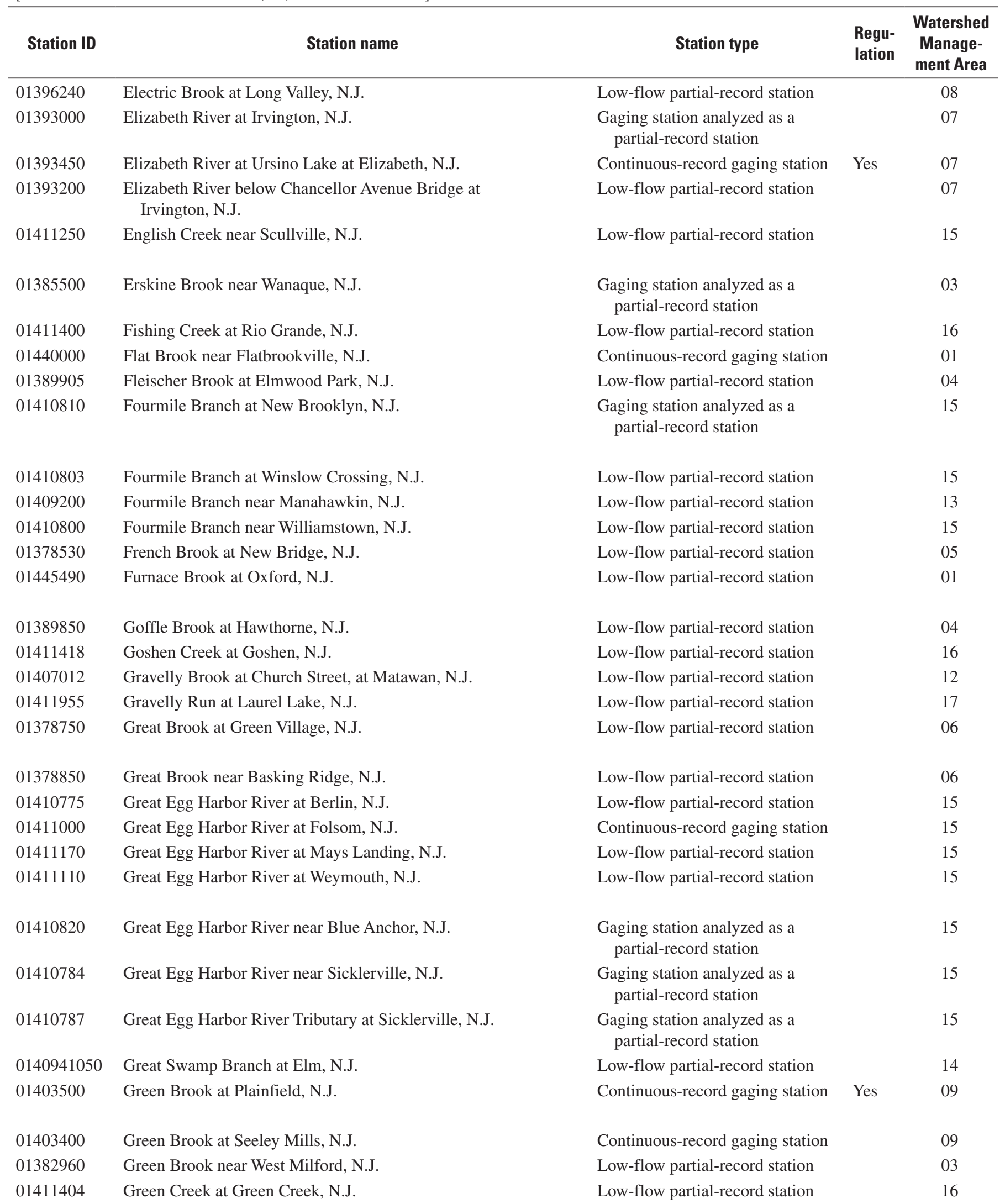


Table 1-2. Index, by station name, of selected continuous-record streamflow-gaging stations, low-flow partial-record stations, and gaging stations analyzed as a partial-record stations in New Jersey, New York, and Pennsylvania.—Continued

[Stations are listed in downstream order; ID, identification number]

\begin{tabular}{|c|c|c|c|c|}
\hline Station ID & Station name & Station type & $\begin{array}{l}\text { Regu- } \\
\text { lation }\end{array}$ & $\begin{array}{c}\text { Watershed } \\
\text { Manage- } \\
\text { ment Area }\end{array}$ \\
\hline 01379773 & Green Pond Brook at Picatinny Arsenal, N.J. & $\begin{array}{l}\text { Gaging station analyzed as a } \\
\text { partial-record station }\end{array}$ & & 06 \\
\hline 01379790 & Green Pond Brook at Wharton, N.J. & $\begin{array}{l}\text { Gaging station analyzed as a } \\
\text { partial-record station }\end{array}$ & & 06 \\
\hline 01466900 & Greenwood Brook at New Lisbon, N.J. & $\begin{array}{l}\text { Gaging station analyzed as a } \\
\text { partial-record station }\end{array}$ & & 19 \\
\hline 01378500 & Hackensack River at New Milford, N.J. & Continuous-record gaging station & Yes & 05 \\
\hline 01377000 & Hackensack River at Rivervale, N.J. & Continuous-record gaging station & Yes & 05 \\
\hline 01409416 & Hammonton Creek at Wescoatville, N.J. & Low-flow partial-record station & & 14 \\
\hline 01456210 & Hances Brook near Beattystown, N.J. & Low-flow partial-record station & & 01 \\
\hline 01407806 & $\begin{array}{l}\text { Hannabrand Brook at Old Mill Road, near Spring Lake } \\
\text { Heights, N.J. }\end{array}$ & Low-flow partial-record station & & 12 \\
\hline 01379150 & Harrisons Brook at Liberty Corner, N.J. & Low-flow partial-record station & & 06 \\
\hline 01407636 & Harvey Brook at West Allenhurst, N.J. & Low-flow partial-record station & & 12 \\
\hline 01456100 & Hatchery Brook at Hackettstown, N.J. & Low-flow partial-record station & & 01 \\
\hline 01387980 & Haycock Brook at Pompton Lakes, N.J. & Low-flow partial-record station & & 03 \\
\hline 01391000 & Hohokus Brook at Ho-Ho-Kus, N.J. & Continuous-record gaging station & & 04 \\
\hline 01390700 & Hohokus Brook at Wyckoff, N.J. & Low-flow partial-record station & & 04 \\
\hline 01398107 & Holland Brook at Readington, N.J. & $\begin{array}{l}\text { Gaging station analyzed as a } \\
\text { partial-record station }\end{array}$ & Yes & 08 \\
\hline 01400953 & Honey Branch near Pennington, N.J. & $\begin{array}{l}\text { Gaging station analyzed as a } \\
\text { partial-record station }\end{array}$ & & 10 \\
\hline 01400970 & Honey Branch near Rosedale, N.J. & Low-flow partial-record station & & 10 \\
\hline 01445900 & Honey Run near Hope, N.J. & Low-flow partial-record station & & 01 \\
\hline 01445800 & Honey Run near Ramseyburg, N.J. & Low-flow partial-record station & & 01 \\
\hline 01407200 & Hop Brook at Holmdel, N.J. & Low-flow partial-record station & & 12 \\
\hline 01411053 & Hospitality Branch at Berryland, N.J. & Low-flow partial-record station & & 15 \\
\hline 01411035 & Hospitality Branch at Blue Bell Road, near Cecil, N.J. & Low-flow partial-record station & & 15 \\
\hline 01411040 & Hospitality Branch near Cecil, N.J. & Low-flow partial-record station & & 15 \\
\hline 01398220 & India Brook near Mendham, N.J. & Low-flow partial-record station & & 08 \\
\hline
\end{tabular}


Table 1-2. Index, by station name, of selected continuous-record streamflow-gaging stations, low-flow partial-record stations, and gaging stations analyzed as a partial-record stations in New Jersey, New York, and Pennsylvania.-Continued

[Stations are listed in downstream order; ID, identification number]

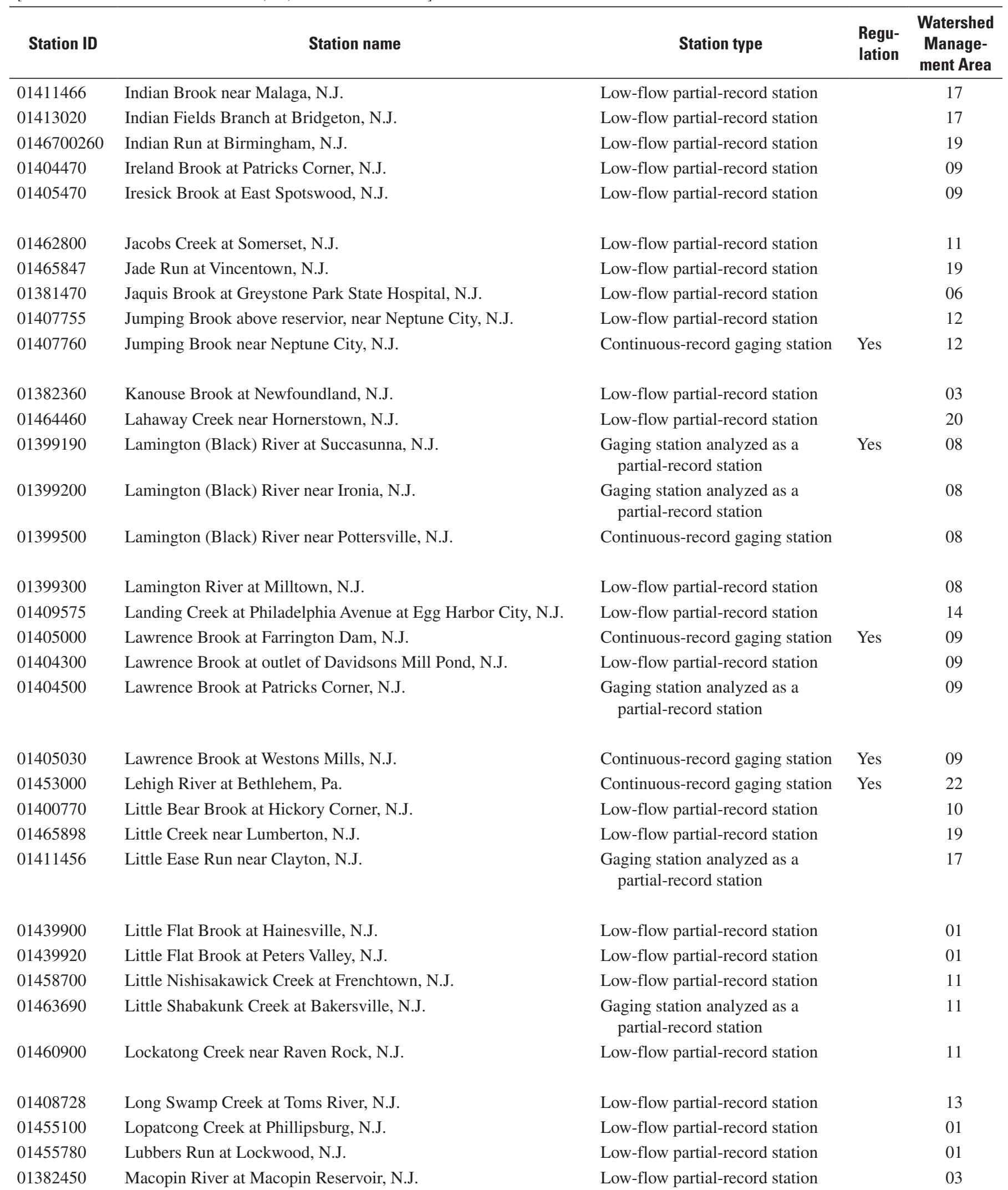


Table 1-2. Index, by station name, of selected continuous-record streamflow-gaging stations, low-flow partial-record stations, and gaging stations analyzed as a partial-record stations in New Jersey, New York, and Pennsylvania.-Continued

[Stations are listed in downstream order; ID, identification number]

\begin{tabular}{|c|c|c|c|c|}
\hline Station ID & Station name & Station type & $\begin{array}{l}\text { Regu- } \\
\text { lation }\end{array}$ & $\begin{array}{c}\text { Watershed } \\
\text { Manage- } \\
\text { ment Area }\end{array}$ \\
\hline 01407065 & Mahoras Brook at Hendrickson Corners, N.J. & Low-flow partial-record station & & 12 \\
\hline 01387480 & Mahwah River at Suffern, N.Y. & Low-flow partial-record station & & 24 \\
\hline 01482530 & Major Run at Sharptown, N.J. & Low-flow partial-record station & & 17 \\
\hline 01381550 & Malapardis Brook at Whippany, N.J. & Low-flow partial-record station & & 06 \\
\hline 01405440 & Manalapan Brook at Bridge Street at Spotswood, N.J. & Low-flow partial-record station & & 09 \\
\hline 01405340 & Manalapan Brook at Federal Road near Manalapan, N.J. & Low-flow partial-record station & & 09 \\
\hline 01408460 & Manapaqua Brook at Lakehurst, N.J. & Low-flow partial-record station & & 13 \\
\hline 01408030 & Manasquan River at Allenwood, N.J. & Low-flow partial-record station & & 12 \\
\hline 01408000 & Manasquan River at Squankum, N.J. & Continuous-record gaging station & & 12 \\
\hline 01407900 & Manasquan River at West Farms, N.J. & Low-flow partial-record station & & 12 \\
\hline 01408029 & Manasquan River near Allenwood, N.J. & $\begin{array}{l}\text { Gaging station analyzed as a } \\
\text { partial-record station }\end{array}$ & Yes & 12 \\
\hline 01407830 & Manasquan River near Georgia, N.J. & Low-flow partial-record station & & 12 \\
\hline 01474950 & Mantua Creek at Glassboro, N.J. & Low-flow partial-record station & & 18 \\
\hline 01474970 & Mantua Creek at Greentree Road, at Glassboro, N.J. & Low-flow partial-record station & & 18 \\
\hline 01405302 & Matchaponix Brook at Mundy Avenue at Spotswood, N.J. & Low-flow partial-record station & & 09 \\
\hline 01405300 & Matchaponix Brook at Spotswood, N.J. & $\begin{array}{l}\text { Gaging station analyzed as a } \\
\text { partial-record station }\end{array}$ & & 09 \\
\hline 01405290 & Matchaponix Brook at Texas, N.J. & Low-flow partial-record station & & 09 \\
\hline 01405240 & Matchaponix Brook near Englishtown, N.J. & Low-flow partial-record station & & 09 \\
\hline 01411485 & Maurice River at Brotmanville, N.J. & $\begin{array}{l}\text { Gaging station analyzed as a } \\
\text { partial-record station }\end{array}$ & & 17 \\
\hline 01411500 & Maurice River at Norma, N.J. & Continuous-record gaging station & & 17 \\
\hline 01411880 & Maurice River at Sharp Street at Millville, N.J. & Low-flow partial-record station & & 17 \\
\hline 01411878 & Maurice River at Union Lake Dam at Millville, N.J. & $\begin{array}{l}\text { Gaging station analyzed as a } \\
\text { partial-record station }\end{array}$ & & 17 \\
\hline 01411800 & Maurice River near Millville, N.J. & $\begin{array}{l}\text { Gaging station analyzed as a } \\
\text { partial-record station }\end{array}$ & & 17 \\
\hline 01466500 & Mcdonalds Branch in Lebanon State Forest, N.J. & Continuous-record gaging station & & 19 \\
\hline 01405180 & Mcgellairds Brook at Englishtown, N.J. & Low-flow partial-record station & & 09 \\
\hline
\end{tabular}


Table 1-2. Index, by station name, of selected continuous-record streamflow-gaging stations, low-flow partial-record stations, and gaging stations analyzed as a partial-record stations in New Jersey, New York, and Pennsylvania.—Continued

[Stations are listed in downstream order; ID, identification number]

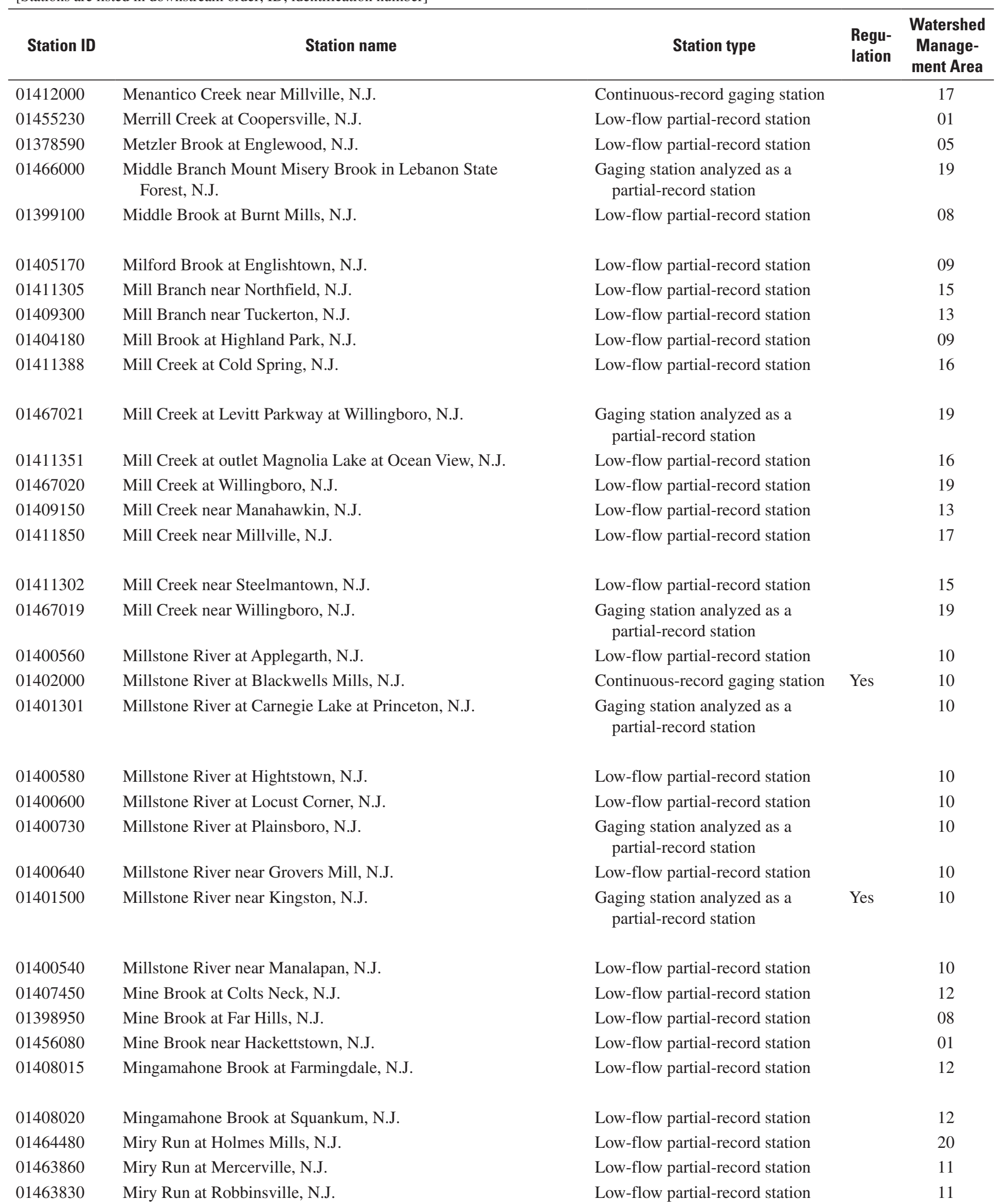


Table 1-2. Index, by station name, of selected continuous-record streamflow-gaging stations, low-flow partial-record stations, and gaging stations analyzed as a partial-record stations in New Jersey, New York, and Pennsylvania.-Continued

[Stations are listed in downstream order; ID, identification number]

\begin{tabular}{|c|c|c|c|c|}
\hline Station ID & Station name & Station type & $\begin{array}{l}\text { Regu- } \\
\text { lation }\end{array}$ & $\begin{array}{c}\text { Watershed } \\
\text { Manage- } \\
\text { ment Area }\end{array}$ \\
\hline 01407026 & Mohingson (Wilkson) Creek at Church Street, at Matawan, N.J. & Low-flow partial-record station & & 12 \\
\hline 01389765 & Molly Ann Brook at North Haledon, N.J. & Low-flow partial-record station & & 04 \\
\hline 01389790 & Molly Ann Brook at Paterson, N.J. & Low-flow partial-record station & & 04 \\
\hline 01462200 & Moores Creek near Titusville, N.J. & Low-flow partial-record station & & 11 \\
\hline 01382910 & Morsetown Brook at West Milford, N.J. & Low-flow partial-record station & & 03 \\
\hline 01445520 & Mountain Lake Brook near Pequest, N.J. & Low-flow partial-record station & & 01 \\
\hline 01411700 & Muddy Run at Centerton, N.J. & Low-flow partial-record station & & 17 \\
\hline 01411650 & Muddy Run near Elmer, N.J. & Low-flow partial-record station & & 17 \\
\hline 01396670 & Mulhockaway Creek Tributary at Van Syckel, N.J. & Low-flow partial-record station & & 08 \\
\hline 01409390 & Mullica River at Atsion, N.J. & Low-flow partial-record station & & 14 \\
\hline 01409387 & Mullica River at outlet of Atsion Lake, at Atsion, N.J. & Low-flow partial-record station & & 14 \\
\hline 01409375 & Mullica River near Atco, N.J. & Low-flow partial-record station & & 14 \\
\hline 01409400 & Mullica River near Batsto, N.J. & Continuous-record gaging station & & 14 \\
\hline 01409395 & Mullica River Tributary near Atsion, N.J. & Low-flow partial-record station & & 14 \\
\hline 01455500 & Musconetcong River at outlet of Lake Hopatcong, N.J. & Continuous-record gaging station & Yes & 01 \\
\hline 01457400 & Musconetcong River at Riegelsville, N.J. & Low-flow partial-record station & & 01 \\
\hline 01455550 & Musconetcong River at Stanhope, N.J. & Low-flow partial-record station & & 01 \\
\hline 01409411 & Nescochague Creek at Pleasant Mills, N.J. & Low-flow partial-record station & & 14 \\
\hline 01398000 & Neshanic River at Reaville, N.J. & Continuous-record gaging station & & 08 \\
\hline 01397800 & Neshanic River near Flemington, N.J. & Low-flow partial-record station & & 08 \\
\hline 01437500 & Neversink River at Godeffroy, N.Y. & Continuous-record gaging station & Yes & 21 \\
\hline 01467305 & Newton Creek at Collingswood, N.J. & Low-flow partial-record station & & 18 \\
\hline 01467312 & Newton Creek at West Collingswood, N.J. & Low-flow partial-record station & & 18 \\
\hline 01482510 & Nichomus Run near Woodstown, N.J. & Low-flow partial-record station & & 17 \\
\hline 01458600 & Nishisakawick Creek at Frenchtown, N.J. & Low-flow partial-record station & & 11 \\
\hline 01458570 & Nishisakawick Creek near Frenchtown, N.J. & Low-flow partial-record station & & 11 \\
\hline 01394600 & Nomahegan Brook near Mountainside, N.J. & Low-flow partial-record station & & 07 \\
\hline 01467350 & North Branch Big Timber Creek at Laurel Springs, N.J. & Low-flow partial-record station & & 18 \\
\hline 01467180 & North Branch Cooper River at Ellisburg, N.J. & Low-flow partial-record station & & 18 \\
\hline 01467160 & North Branch Cooper River near Marlton, N.J. & Low-flow partial-record station & & 18 \\
\hline
\end{tabular}


Table 1-2. Index, by station name, of selected continuous-record streamflow-gaging stations, low-flow partial-record stations, and gaging stations analyzed as a partial-record stations in New Jersey, New York, and Pennsylvania.—Continued

[Stations are listed in downstream order; ID, identification number]

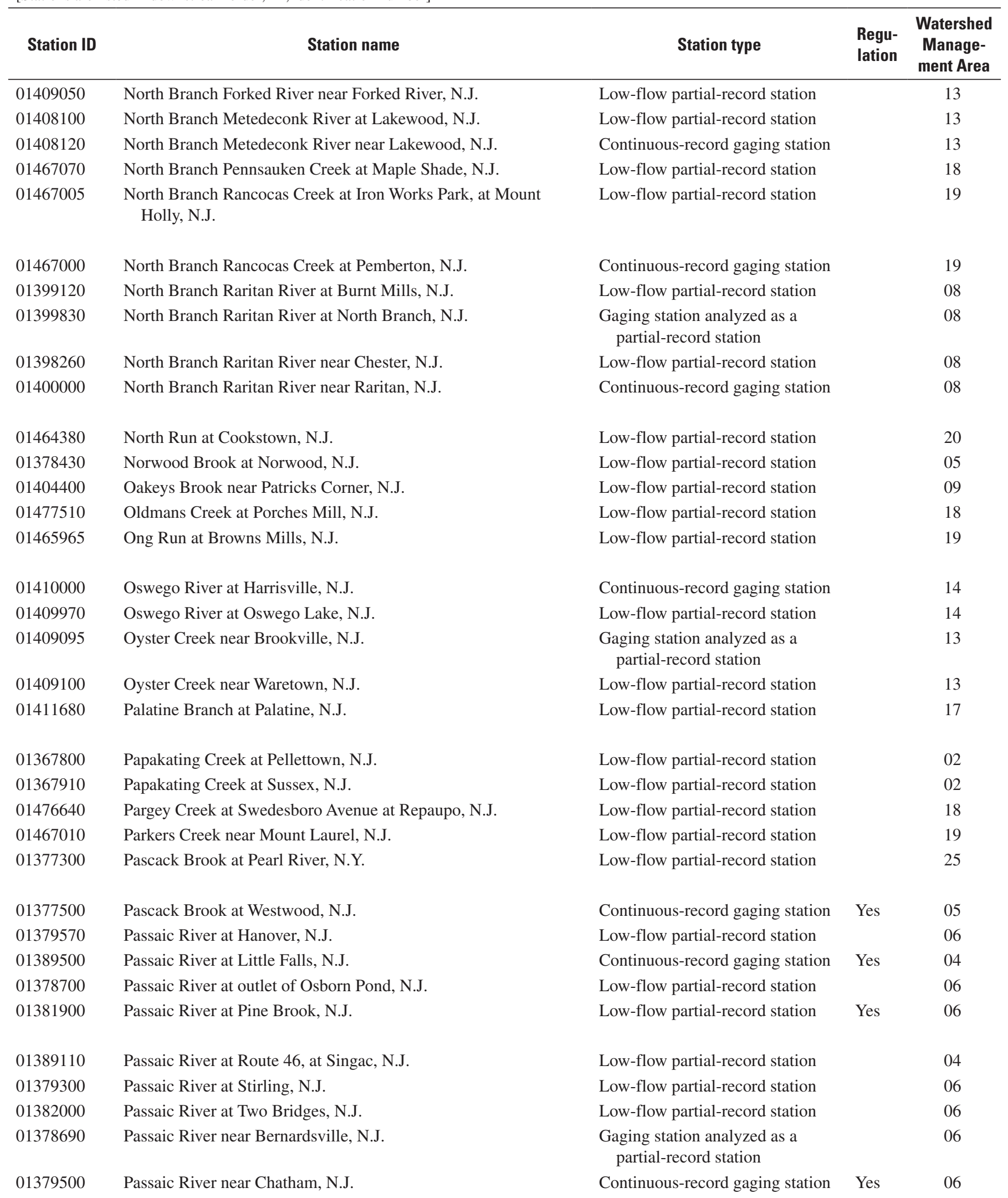


Table 1-2. Index, by station name, of selected continuous-record streamflow-gaging stations, low-flow partial-record stations, and gaging stations analyzed as a partial-record stations in New Jersey, New York, and Pennsylvania.—Continued

[Stations are listed in downstream order; ID, identification number]

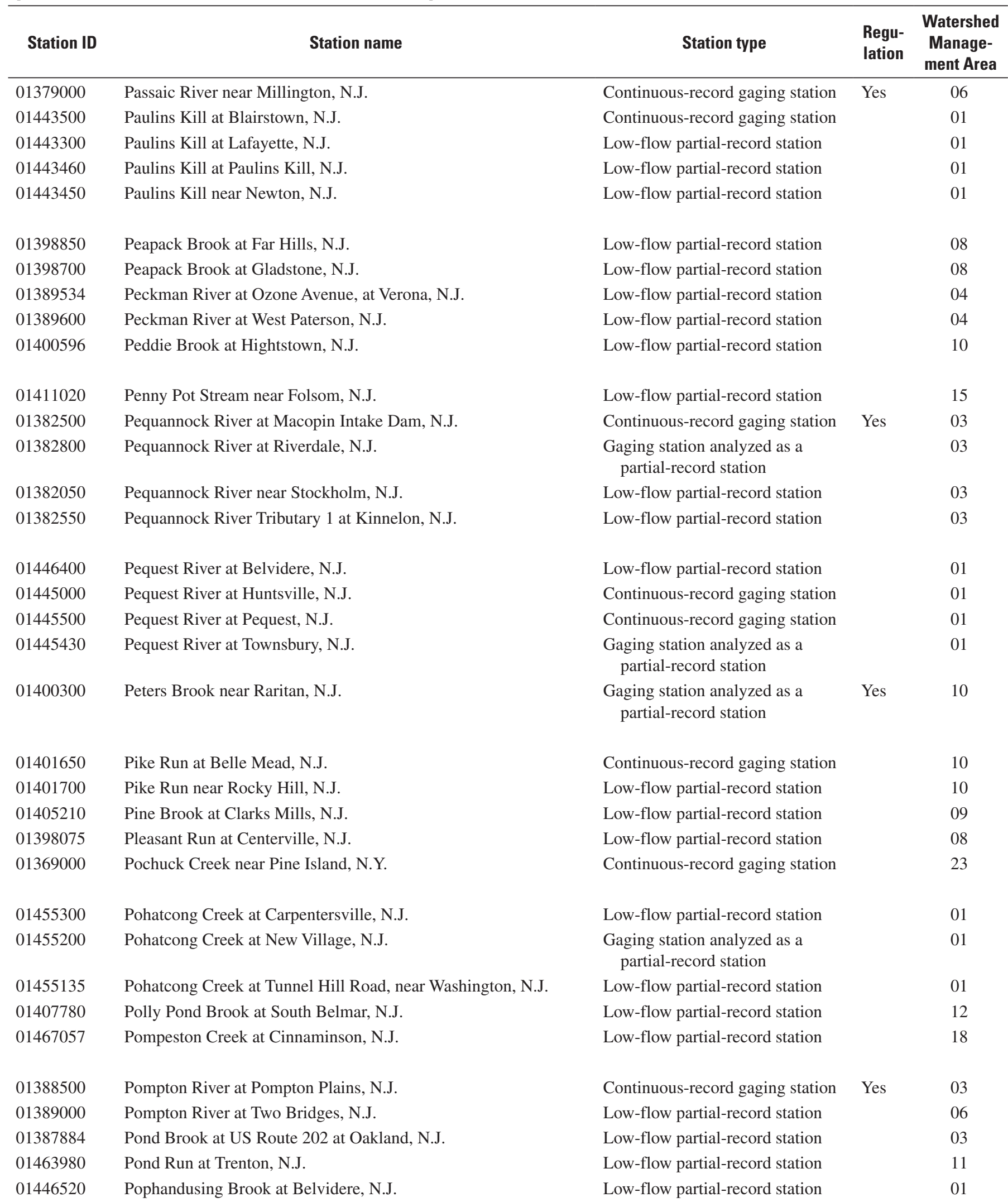


Table 1-2. Index, by station name, of selected continuous-record streamflow-gaging stations, low-flow partial-record stations, and gaging stations analyzed as a partial-record stations in New Jersey, New York, and Pennsylvania.-Continued

[Stations are listed in downstream order; ID, identification number]

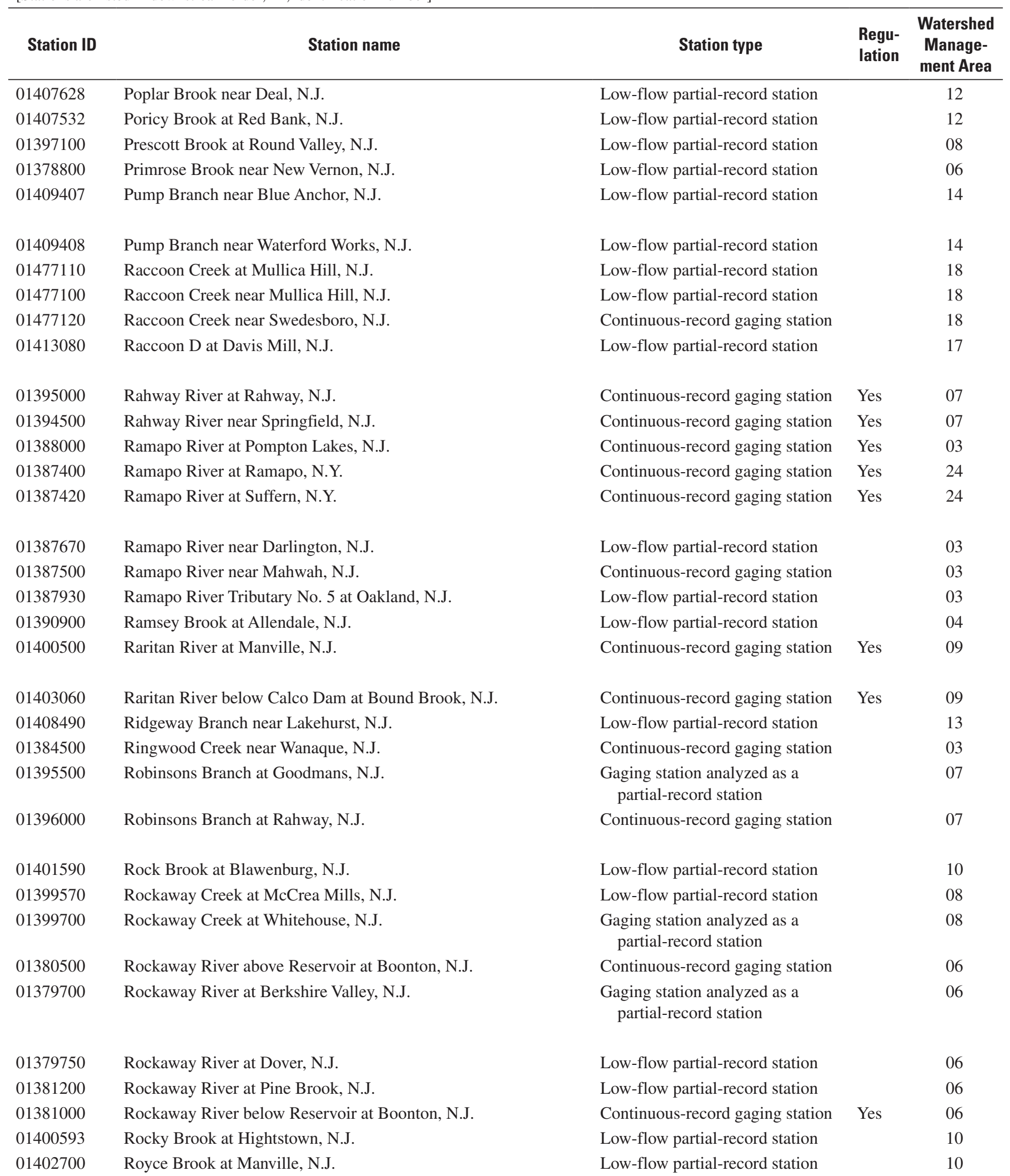


Table 1-2. Index, by station name, of selected continuous-record streamflow-gaging stations, low-flow partial-record stations, and gaging stations analyzed as a partial-record stations in New Jersey, New York, and Pennsylvania.—Continued

[Stations are listed in downstream order; ID, identification number]

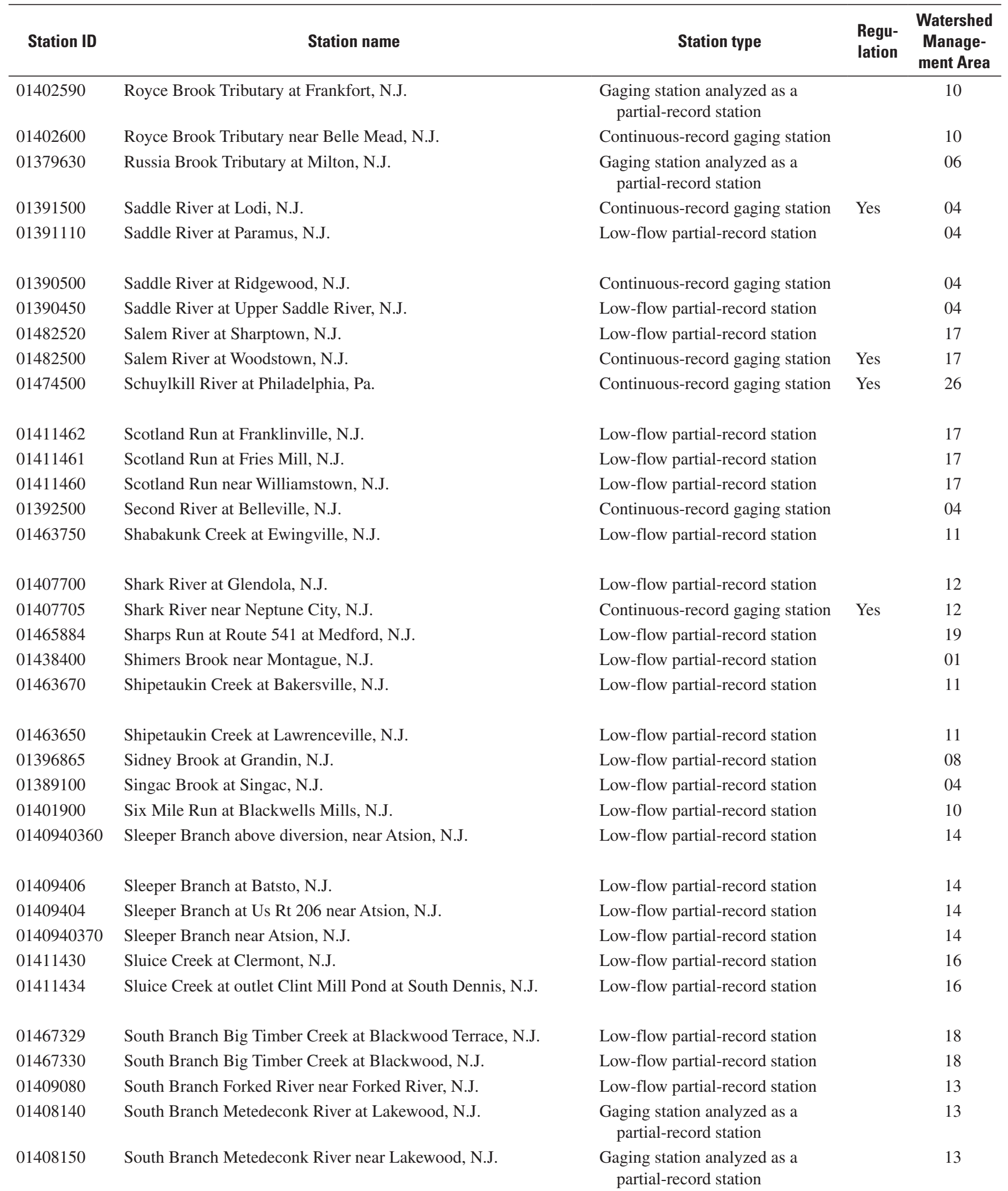


Table 1-2. Index, by station name, of selected continuous-record streamflow-gaging stations, low-flow partial-record stations, and gaging stations analyzed as a partial-record stations in New Jersey, New York, and Pennsylvania.-Continued

[Stations are listed in downstream order; ID, identification number]

\begin{tabular}{|c|c|c|c|c|}
\hline Station ID & Station name & Station type & $\begin{array}{l}\text { Regu- } \\
\text { lation }\end{array}$ & $\begin{array}{c}\text { Watershed } \\
\text { Manage- } \\
\text { ment Area }\end{array}$ \\
\hline 01467317 & South Branch Newton Creek at Haddon Heights, N.J. & Low-flow partial-record station & & 18 \\
\hline 01467081 & South Branch Pennsauken Creek at Cherry Hill, N.J. & Continuous-record gaging station & & 18 \\
\hline 01477118 & South Branch Raccoon Creek near Mullica Hill, N.J. & Low-flow partial-record station & & 18 \\
\hline 01396030 & South Branch Rahway River at Colonia, N.J. & Low-flow partial-record station & & 07 \\
\hline 01465850 & South Branch Rancocas Creek at Vincentown, N.J. & $\begin{array}{l}\text { Gaging station analyzed as a } \\
\text { partial-record station }\end{array}$ & & 19 \\
\hline 01396190 & South Branch Raritan River at Four Bridges, N.J. & $\begin{array}{l}\text { Gaging station analyzed as a } \\
\text { partial-record station }\end{array}$ & & 08 \\
\hline 01396280 & South Branch Raritan River at Middle Valley, N.J. & Low-flow partial-record station & & 08 \\
\hline 01396090 & South Branch Raritan River at outlet of Budd Lake, N.J. & Low-flow partial-record station & & 08 \\
\hline 01398102 & South Branch Raritan River at South Branch, N.J. & Low-flow partial-record station & & 08 \\
\hline 01397000 & South Branch Raritan River at Stanton, N.J. & Continuous-record gaging station & Yes & 08 \\
\hline 01396500 & South Branch Raritan River near High Bridge, N.J. & Continuous-record gaging station & & 08 \\
\hline 01396070 & South Branch Raritan River Tributary 6 at Budd Lake, N.J. & Low-flow partial-record station & & 08 \\
\hline 01465900 & Southwest Branch Rancocas at Eayerstown, N.J. & Low-flow partial-record station & & 19 \\
\hline 01465880 & Southwest Branch Rancocas Creek at Medford, N.J. & Low-flow partial-record station & & 19 \\
\hline 01409460 & Springers Brook near Atsion, N.J. & Low-flow partial-record station & & 14 \\
\hline 01409450 & Springers Brook near Indian Mills, N.J. & Low-flow partial-record station & & 14 \\
\hline 01391485 & Sprout Brook at Rochelle Park, N.J. & Low-flow partial-record station & & 04 \\
\hline 01396800 & Spruce Run at Clinton, N.J. & Continuous-record gaging station & Yes & 08 \\
\hline 01396580 & Spruce Run at Glen Gardner, N.J. & Continuous-record gaging station & & 08 \\
\hline 01396550 & Spruce Run at Newport, N.J. & Low-flow partial-record station & & 08 \\
\hline 01396600 & Spruce Run near Clinton, N.J. & Low-flow partial-record station & & 08 \\
\hline 01396588 & Spruce Run near Glen Gardner, N.J. & Low-flow partial-record station & & 08 \\
\hline 01396590 & Spruce Run near High Bridge, N.J. & Low-flow partial-record station & & 08 \\
\hline 01410865 & Squankum Branch at Malaga Road, near Williamstown, N.J. & Low-flow partial-record station & & 15 \\
\hline
\end{tabular}


Table 1-2. Index, by station name, of selected continuous-record streamflow-gaging stations, low-flow partial-record stations, and gaging stations analyzed as a partial-record stations in New Jersey, New York, and Pennsylvania.—Continued

[Stations are listed in downstream order; ID, identification number]

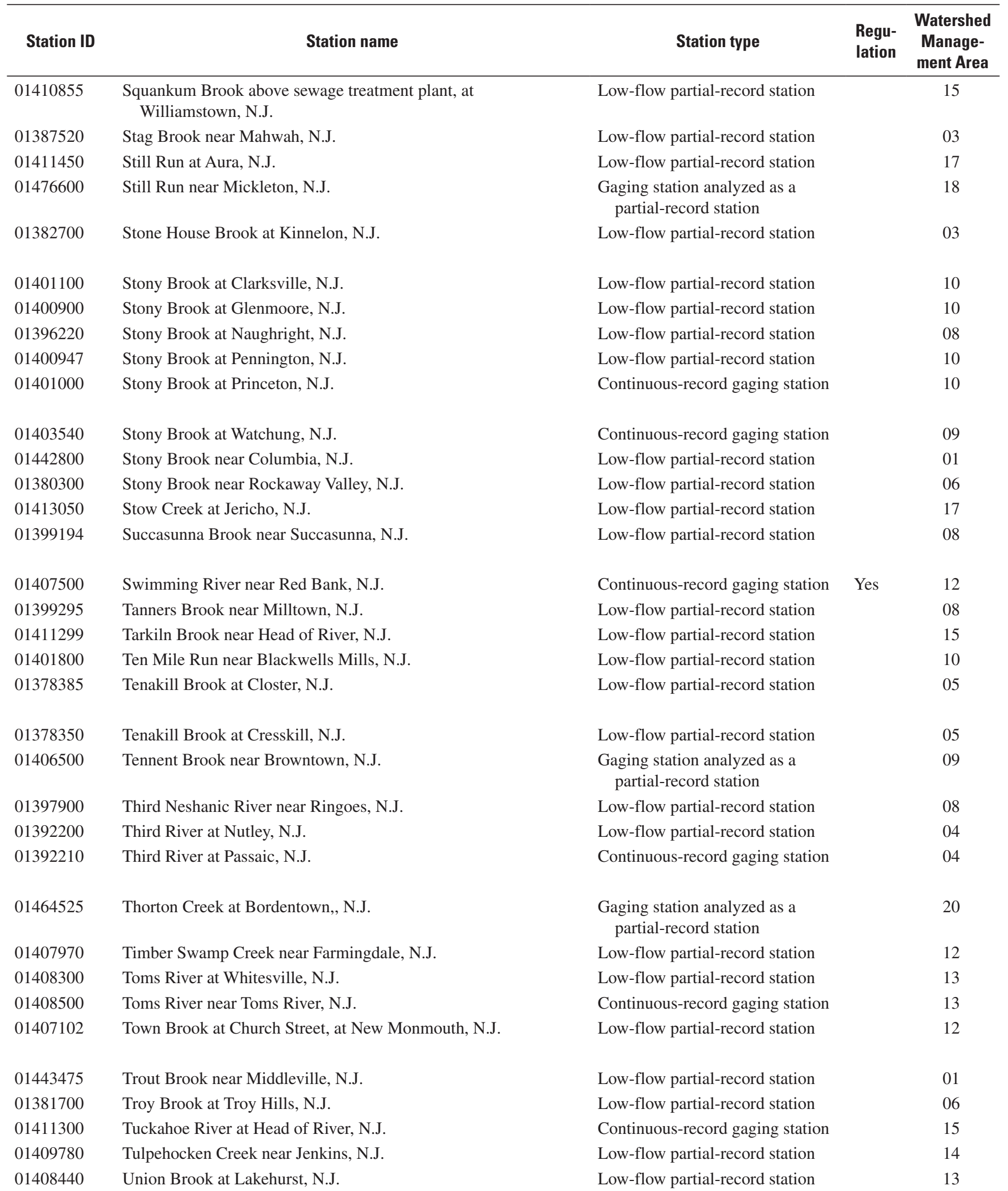


Table 1-2. Index, by station name, of selected continuous-record streamflow-gaging stations, low-flow partial-record stations, and gaging stations analyzed as a partial-record stations in New Jersey, New York, and Pennsylvania.-Continued

[Stations are listed in downstream order; ID, identification number]

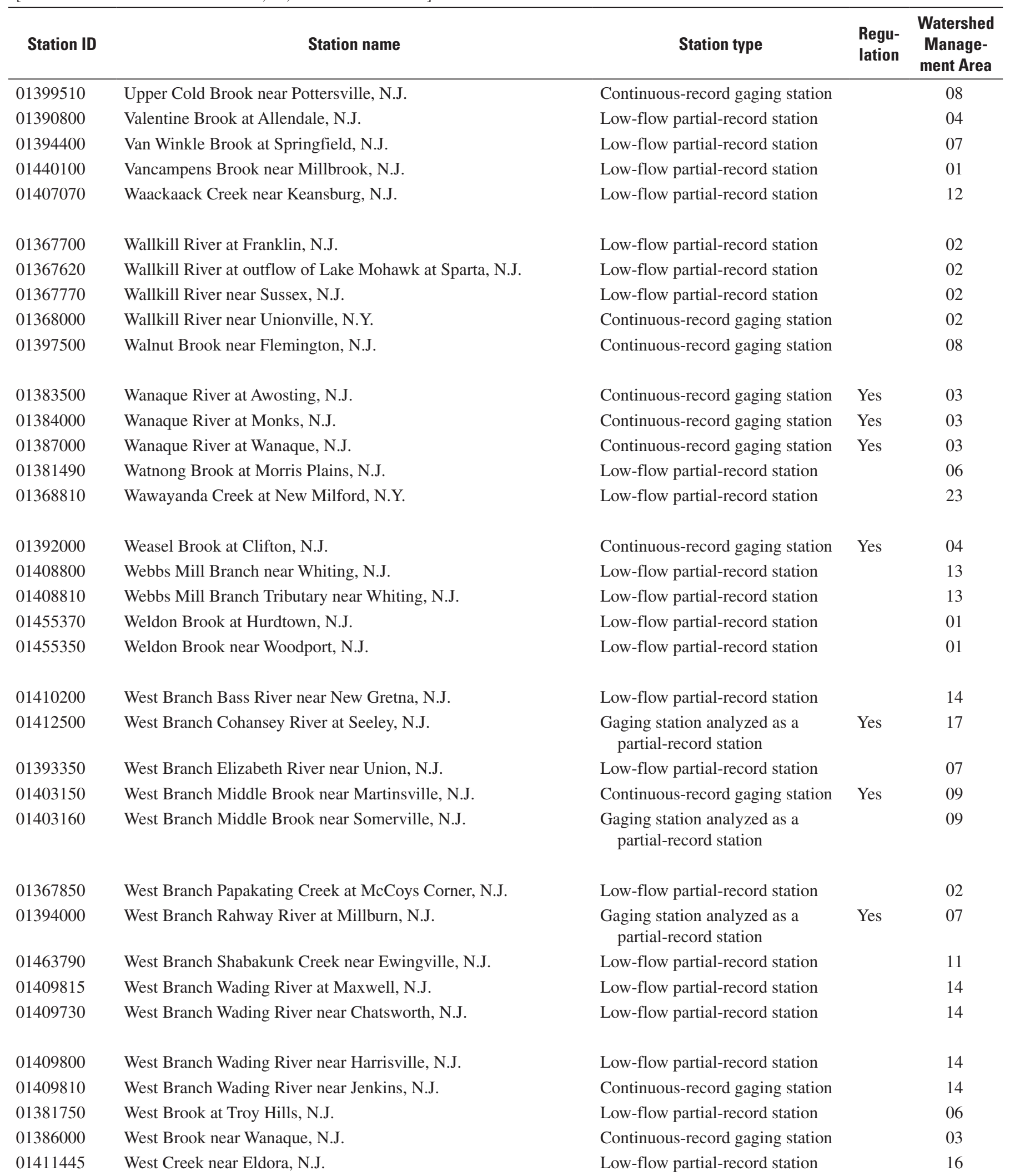


Table 1-2. Index, by station name, of selected continuous-record streamflow-gaging stations, low-flow partial-record stations, and gaging stations analyzed as a partial-record stations in New Jersey, New York, and Pennsylvania.-Continued

[Stations are listed in downstream order; ID, identification number]

\begin{tabular}{|c|c|c|c|c|}
\hline Station ID & Station name & Station type & $\begin{array}{l}\text { Regu- } \\
\text { lation }\end{array}$ & $\begin{array}{c}\text { Watershed } \\
\text { Manage- } \\
\text { ment Area }\end{array}$ \\
\hline 01409280 & Westecunk Creek at Stafford Forge, N.J. & $\begin{array}{l}\text { Gaging station analyzed as a } \\
\text { partial-record station }\end{array}$ & & 13 \\
\hline 01407618 & Whale Pond Brook near Oakhurst, N.J. & Low-flow partial-record station & & 12 \\
\hline 01381400 & Whippany River near Morristown, N.J. & $\begin{array}{l}\text { Gaging station analyzed as a } \\
\text { partial-record station }\end{array}$ & & 06 \\
\hline 01381800 & Whippany River near Pine Brook, N.J. & $\begin{array}{l}\text { Gaging station analyzed as a } \\
\text { partial-record station }\end{array}$ & & 06 \\
\hline 01461300 & Wickecheoke Creek at Stockton, N.J. & Low-flow partial-record station & & 11 \\
\hline 01409403 & Wildcat Branch at Chesilhurst, N.J. & Low-flow partial-record station & & 14 \\
\hline 0140940310 & Wildcat Branch near Chesilhurst, N.J. & Low-flow partial-record station & & 14 \\
\hline 01407250 & Willow Brook at Holmdel, N.J. & Low-flow partial-record station & & 12 \\
\hline 01378615 & Wolf Creek at Ridgefield, N.J. & Low-flow partial-record station & & 05 \\
\hline 01400850 & Woodsville Brook at Woodsville, N.J. & Low-flow partial-record station & & 10 \\
\hline
\end{tabular}



Appendix 2 


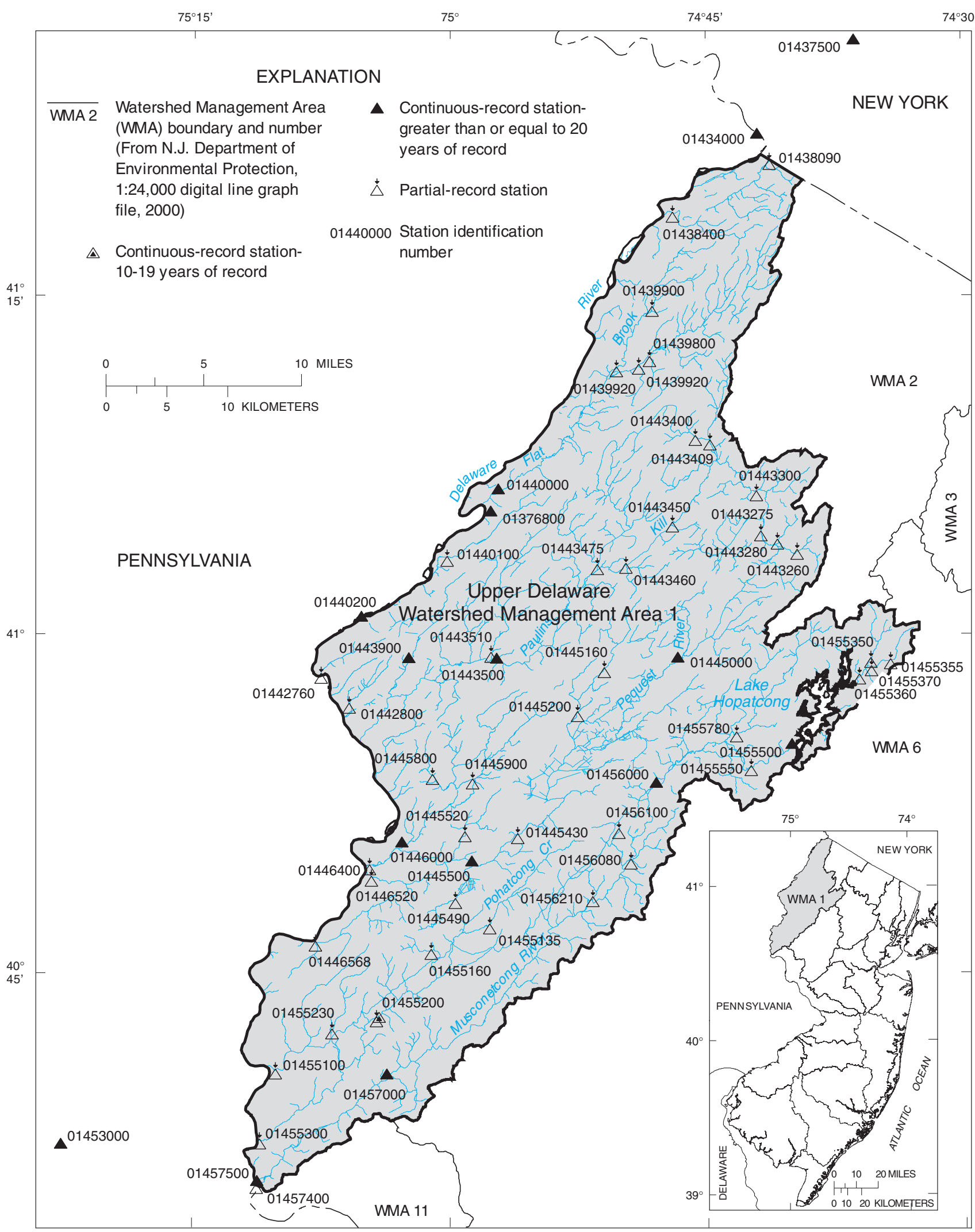

Base from U.S. Geological Survey digital line graph files, 1:24,000

Figure 2-1. Location of streamflow-gaging stations in Watershed Management Area 1 (Upper Delaware) in New Jersey and in New York. 


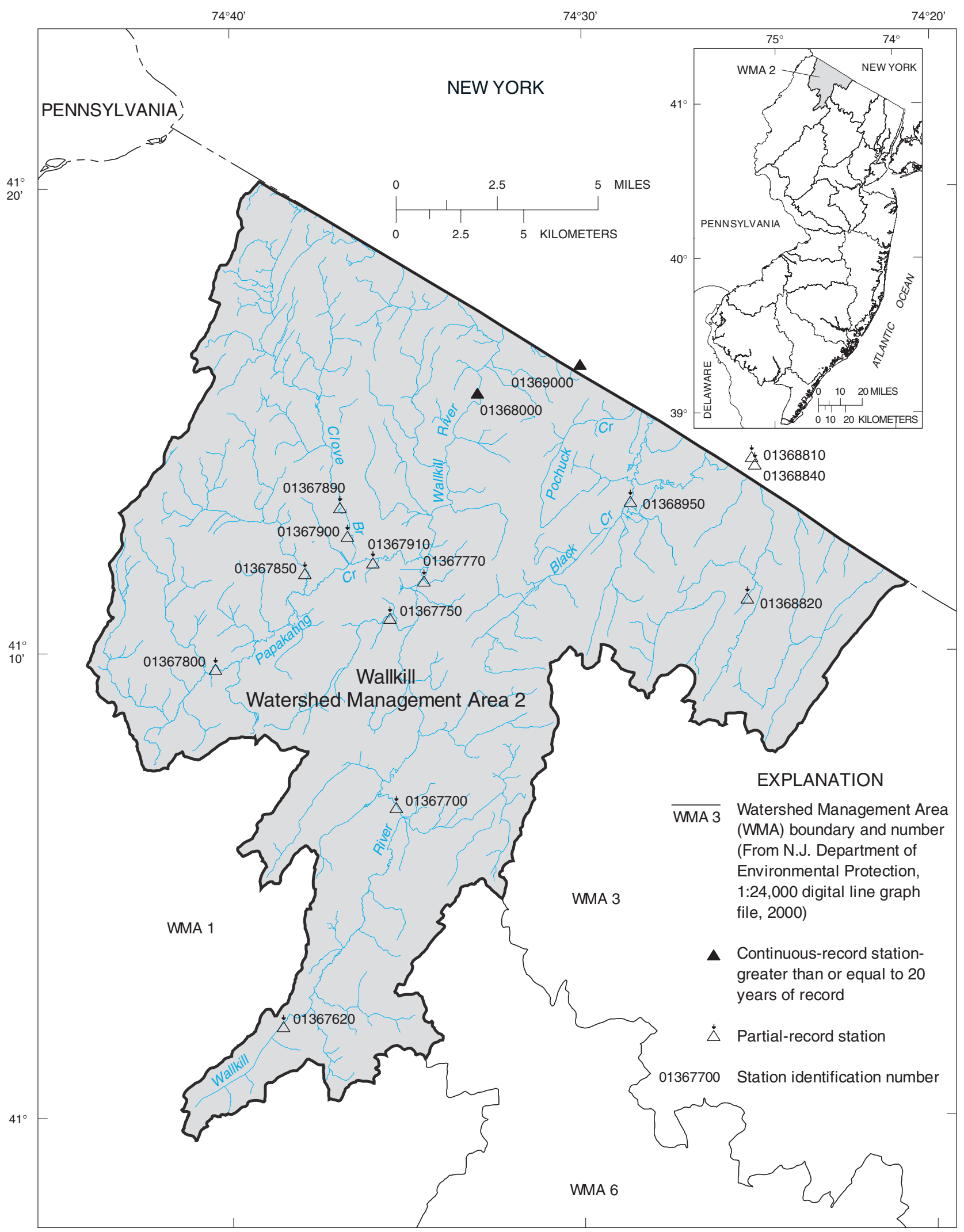

Base from U.S. Geological Survey digital line graph files, 1:24,000

Figure 2-2. Location of streamflow-gaging stations in Watershed Management Area 2 (Wallkill) in New Jersey and in New York. 


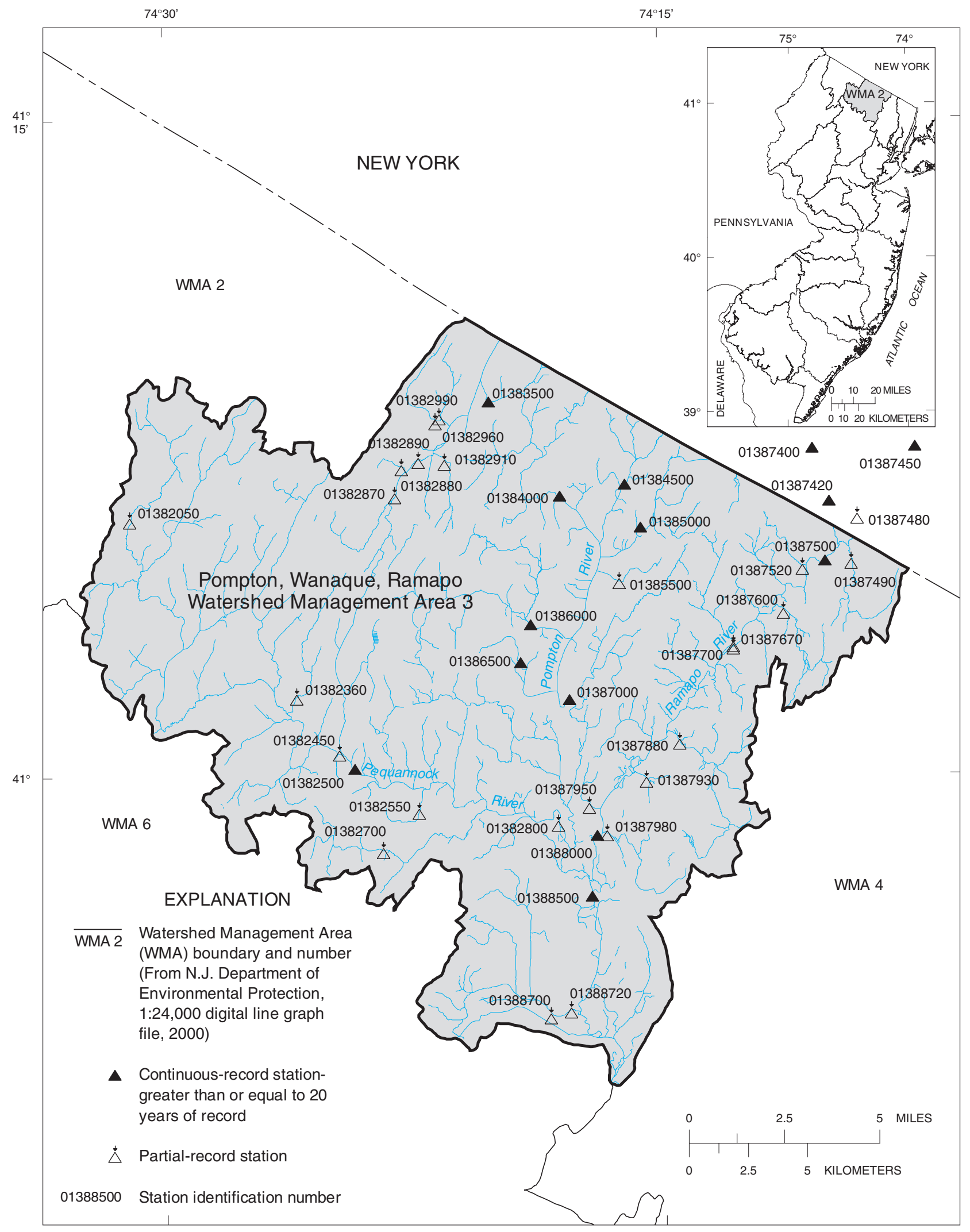

Base from U.S. Geological Survey

digital line graph files, 1:24,000

Figure 2-3. Location of streamflow-gaging stations in Watershed Management Area 3 (Pompton, Wanaque, Ramapo) in New Jersey and in New York. 


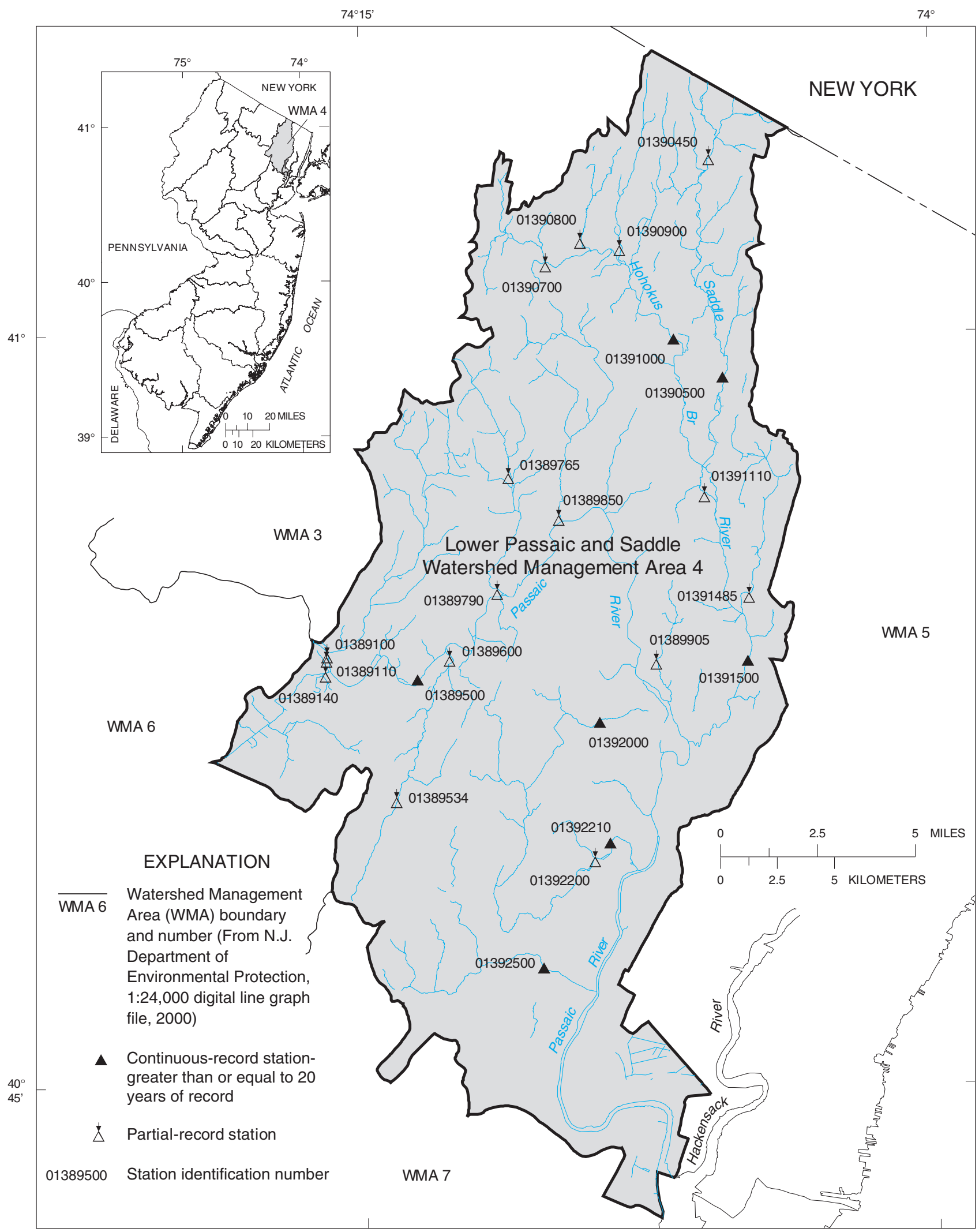

Base from U.S. Geological Survey

digital line graph files, 1:24,000

Figure 2-4. Location of streamflow-gaging stations in Watershed Management Area 4 (Lower Passaic and Saddle) in New Jersey. 


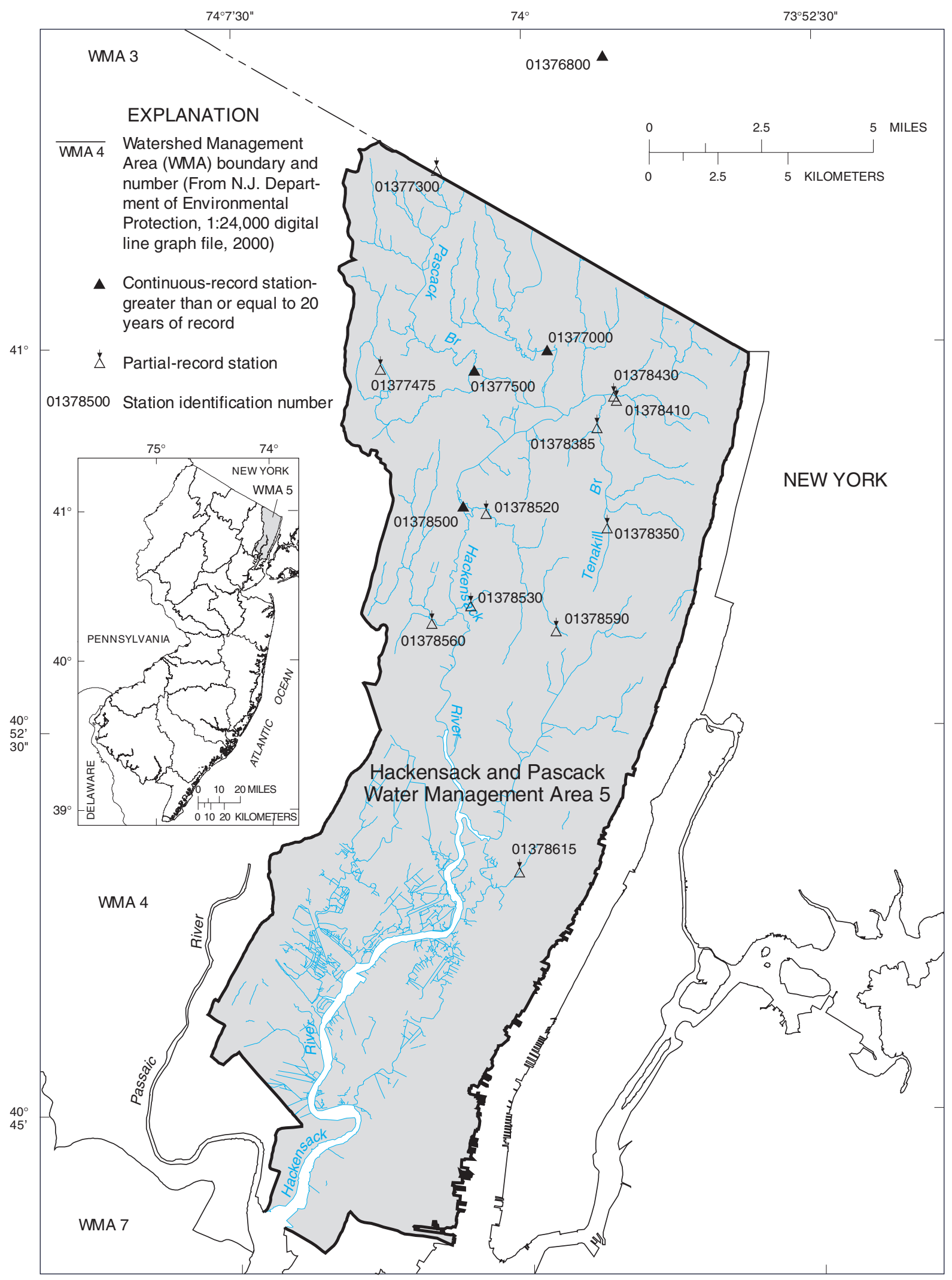

Base from U.S. Geological Survey digital line graph files, 1:24,000

Figure 2-5. Location of streamflow-gaging stations in Watershed Management Area 5 (Hackensack and Pascack) in New Jersey and in New York. 


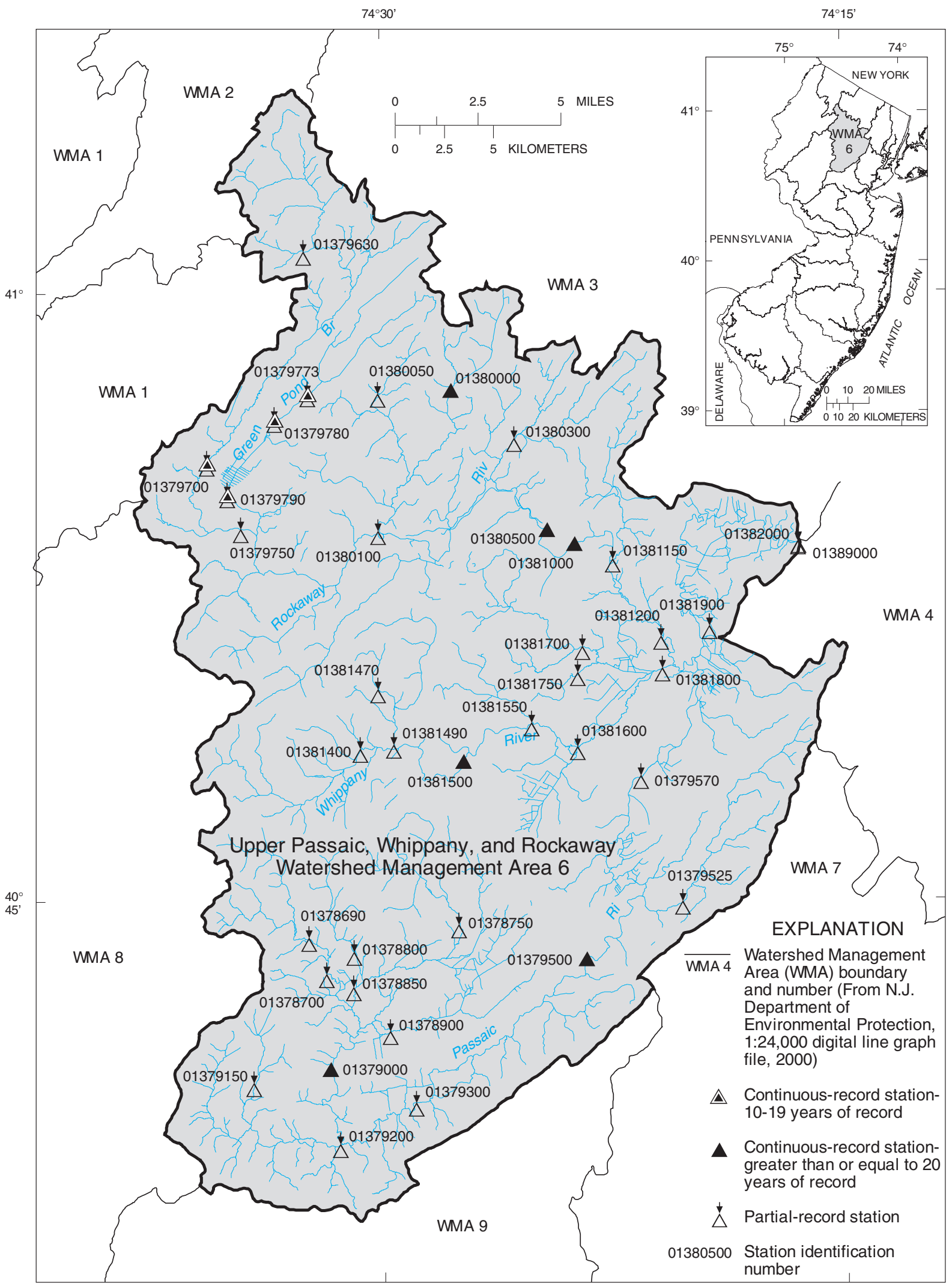

Base from U.S. Geological Survey digital line graph files, 1:24,000

Figure 2-6. Location of streamflow-gaging stations in Watershed Management Area 6 (Upper Passaic, Whippany, and Rockaway) in New Jersey. 


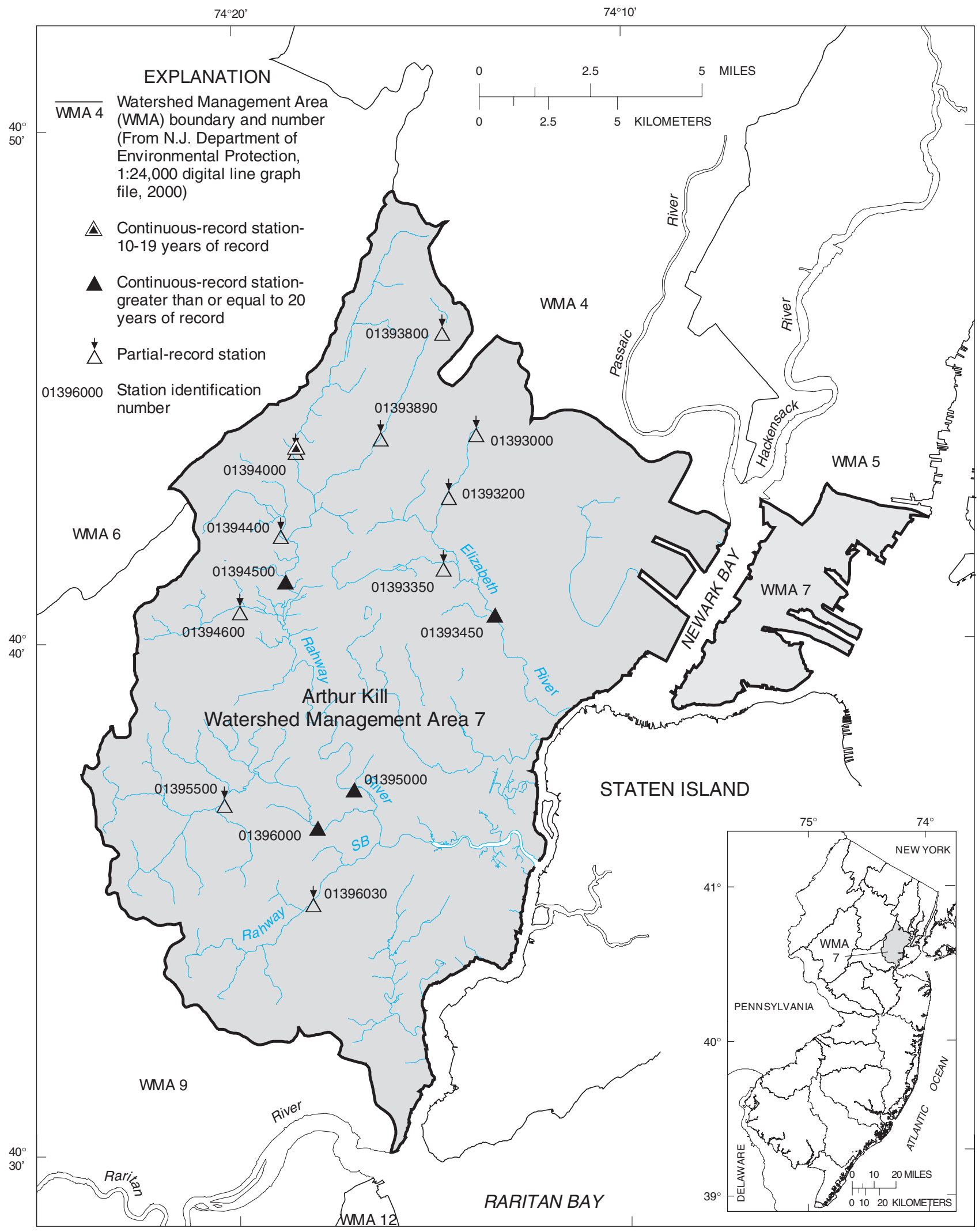

Base from U.S. Geological Survey digital line graph files, 1:24,000

Figure 2-7. Location of streamflow-gaging stations in Watershed Management Area 7 (Arthur Kill) in New Jersey. 


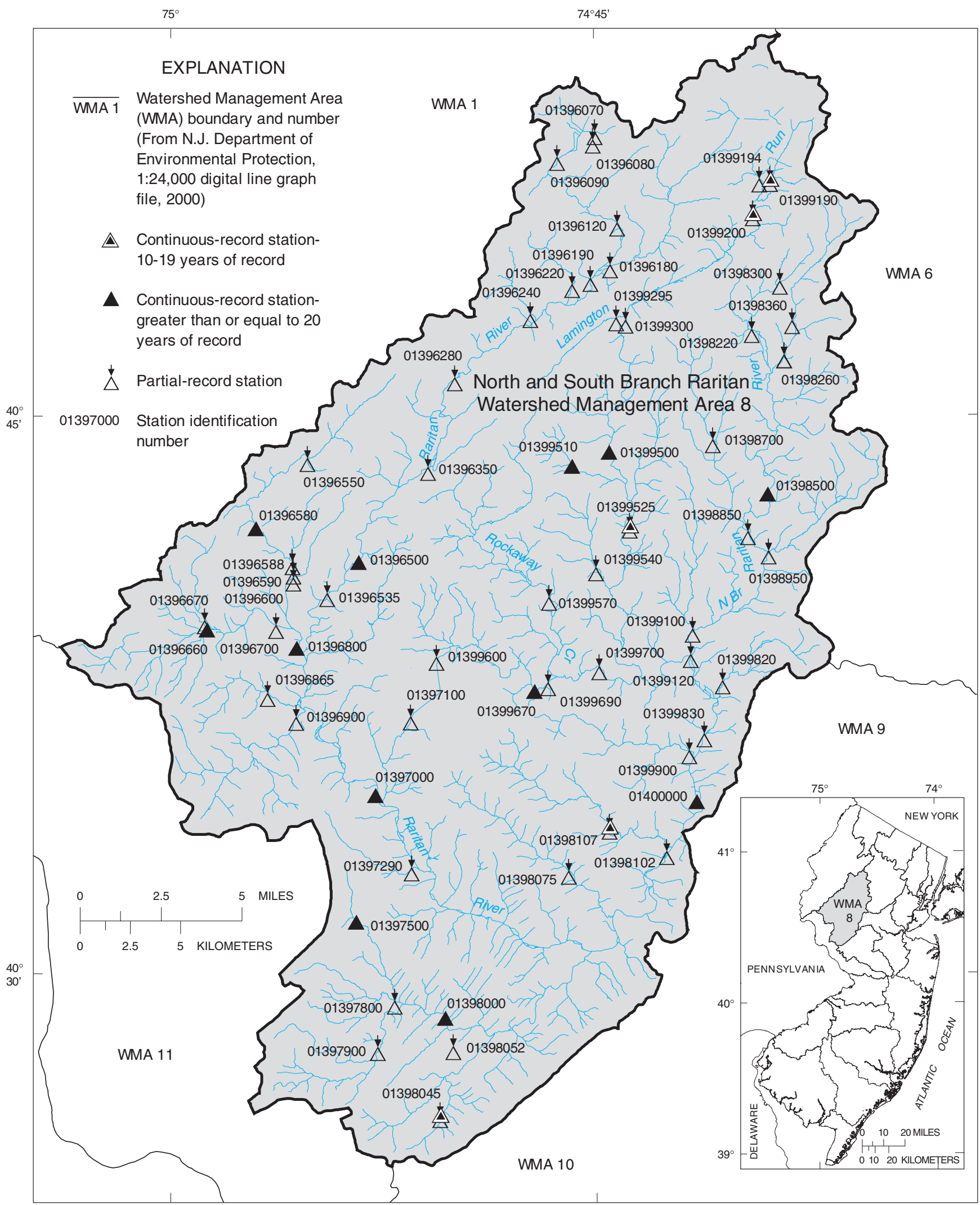

Base from U.S. Geological Survey digital line graph files, 1:24,000

Figure 2-8. Location of streamflow-gaging stations in Watershed Management Area 8 (North and South Branch Raritan) in New Jersey. 


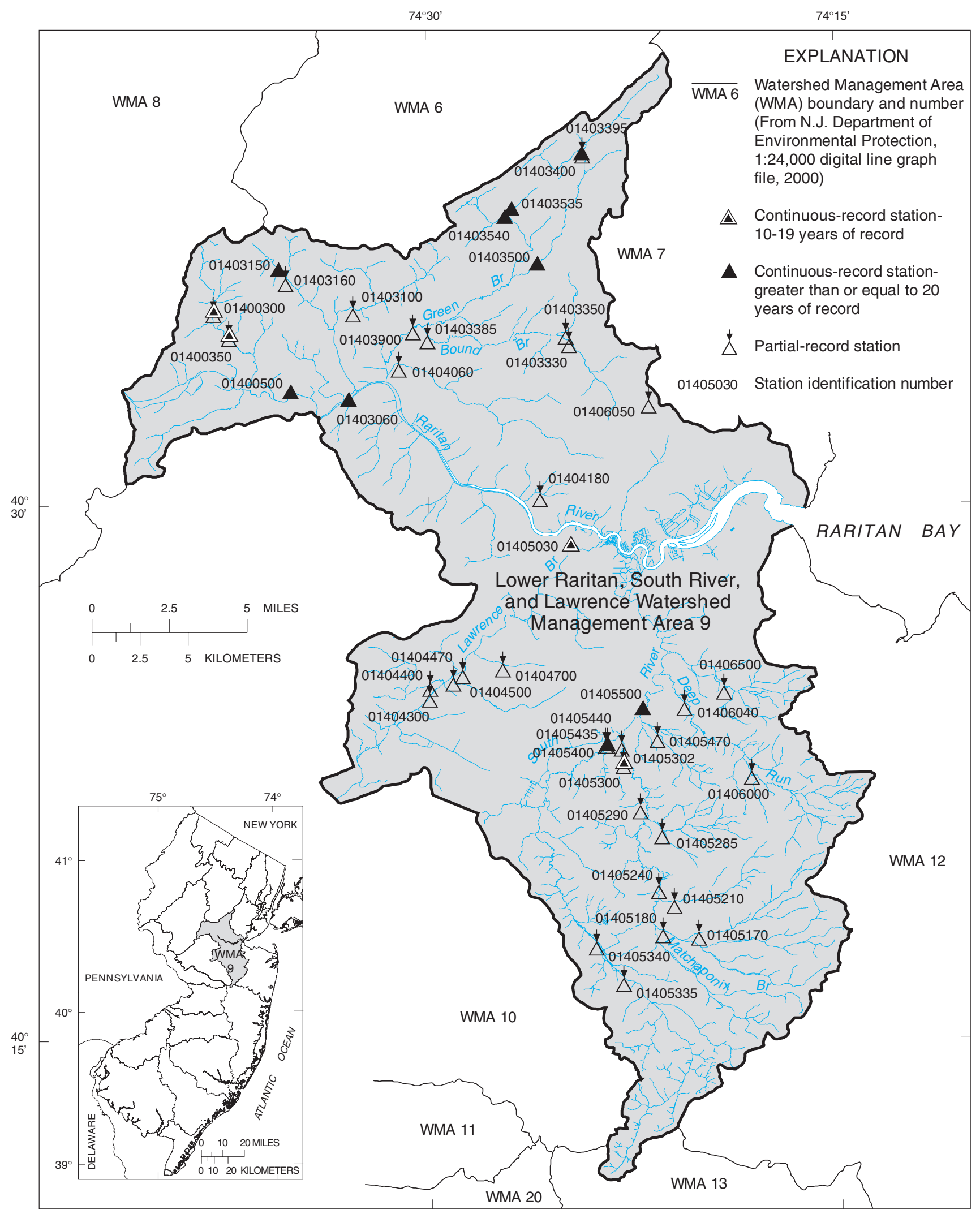

Base from U.S. Geological Survey digital line graph files, 1:24,000

Figure 2-9. Location of streamflow-gaging stations in Watershed Management Area 9 (Lower Raritan, South River and Lawrence) in New Jersey. 


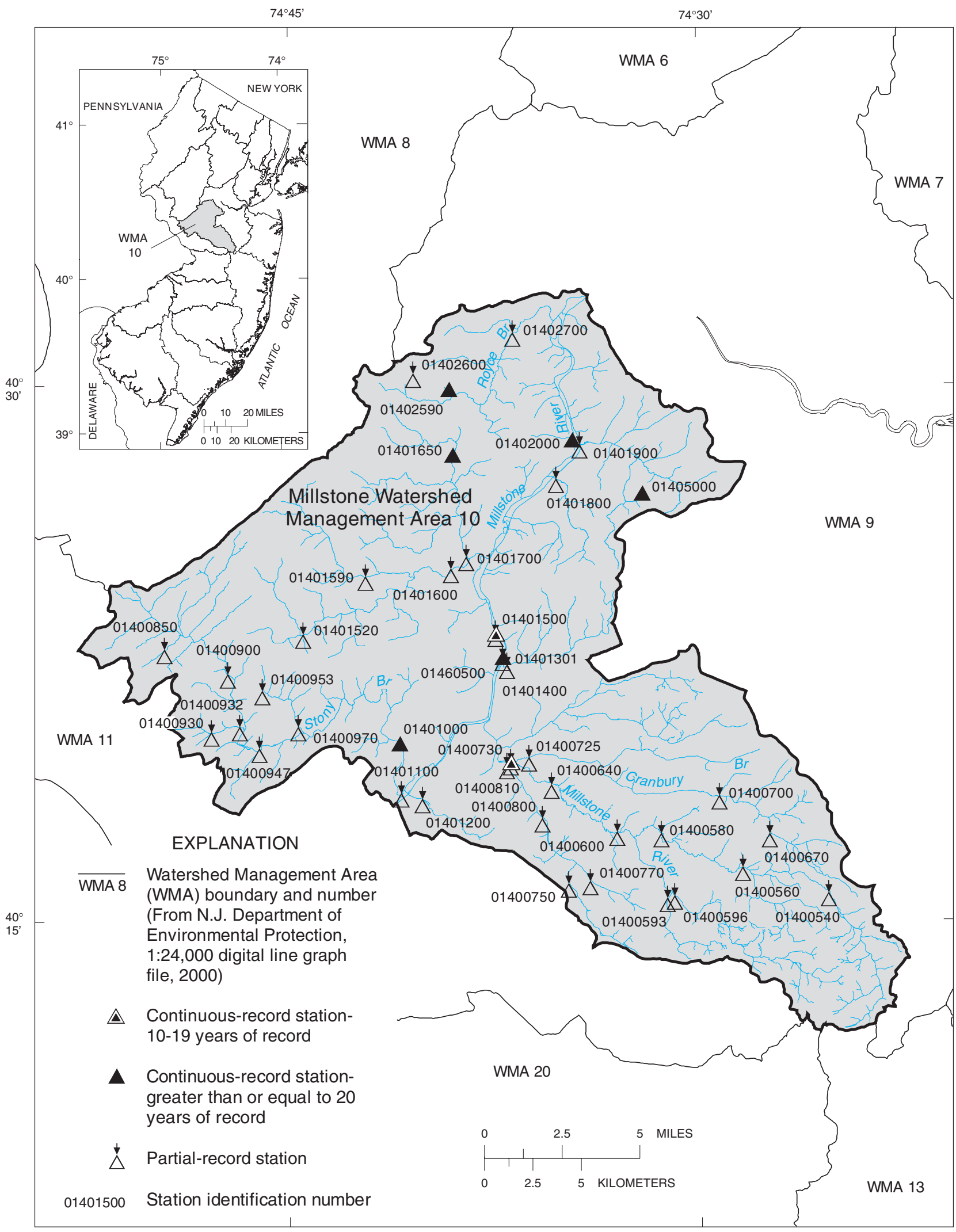

Base from U.S. Geological Survey

digital line graph files, 1:24,000

Figure 2-10. Location of streamflow-gaging stations in Watershed Management Area 10 (Millstone) in New Jersey. 


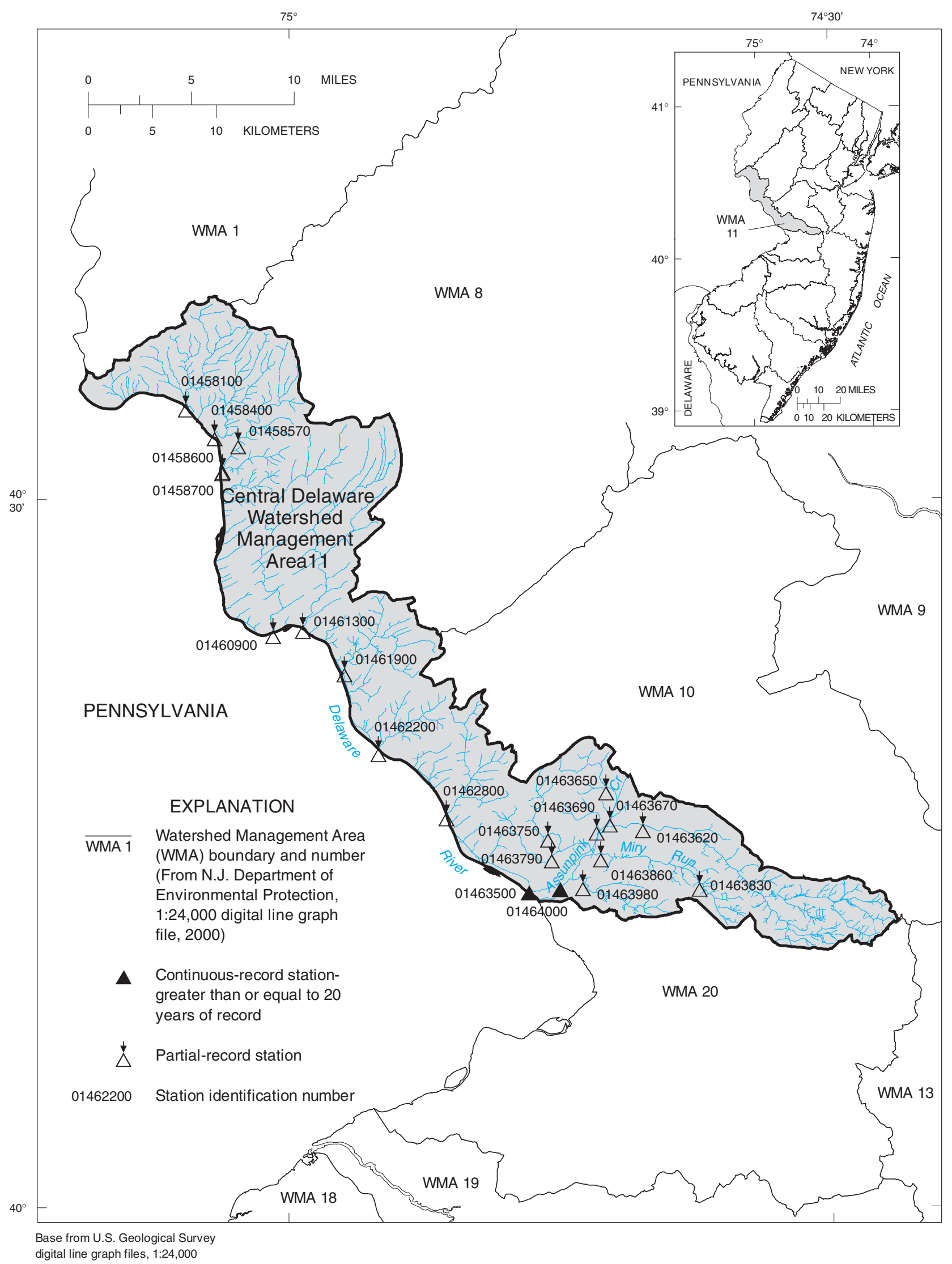

Figure 2-11. Location of streamflow-gaging stations in Watershed Management Area 11 (Central Delaware) in New Jersey. 


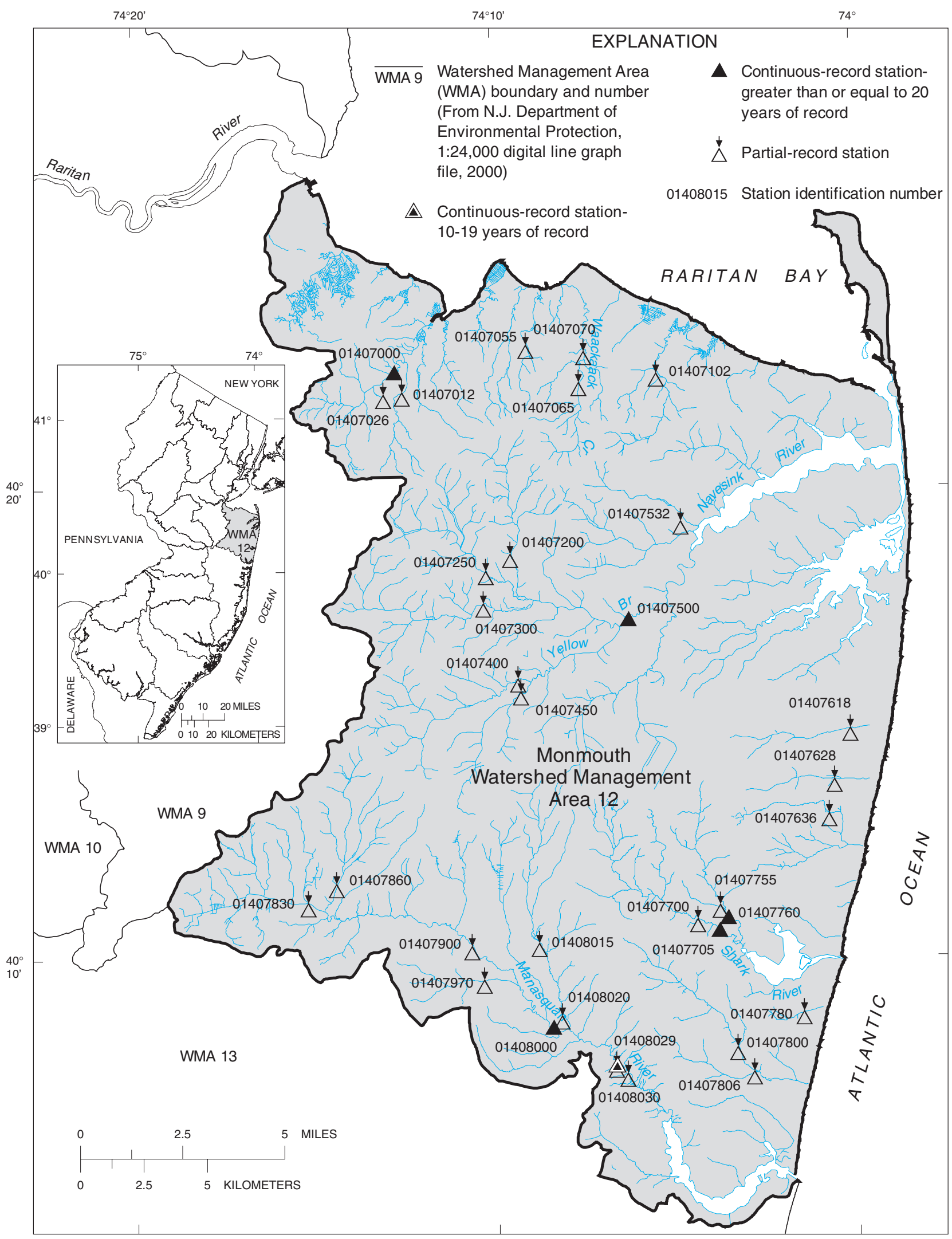

Base from U.S. Geological Survey digital line graph files, 1:24,000

Figure 2-12. Location of streamflow-gaging stations in Watershed Management Area 12 (Monmouth) in New Jersey. 


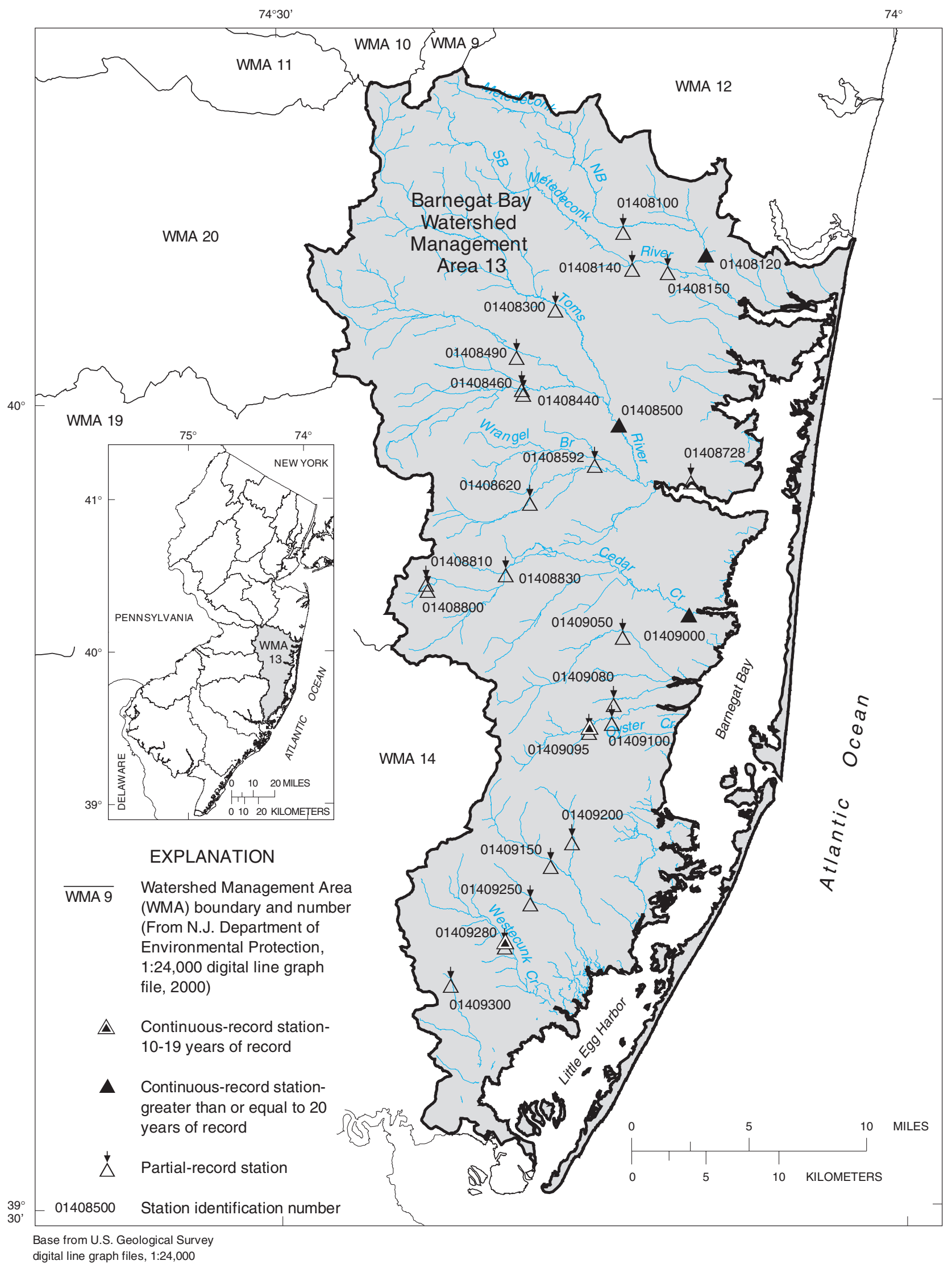

Figure 2-13. Location of streamflow-gaging stations in Watershed Management Area 13 (Barnegat Bay) in New Jersey. 


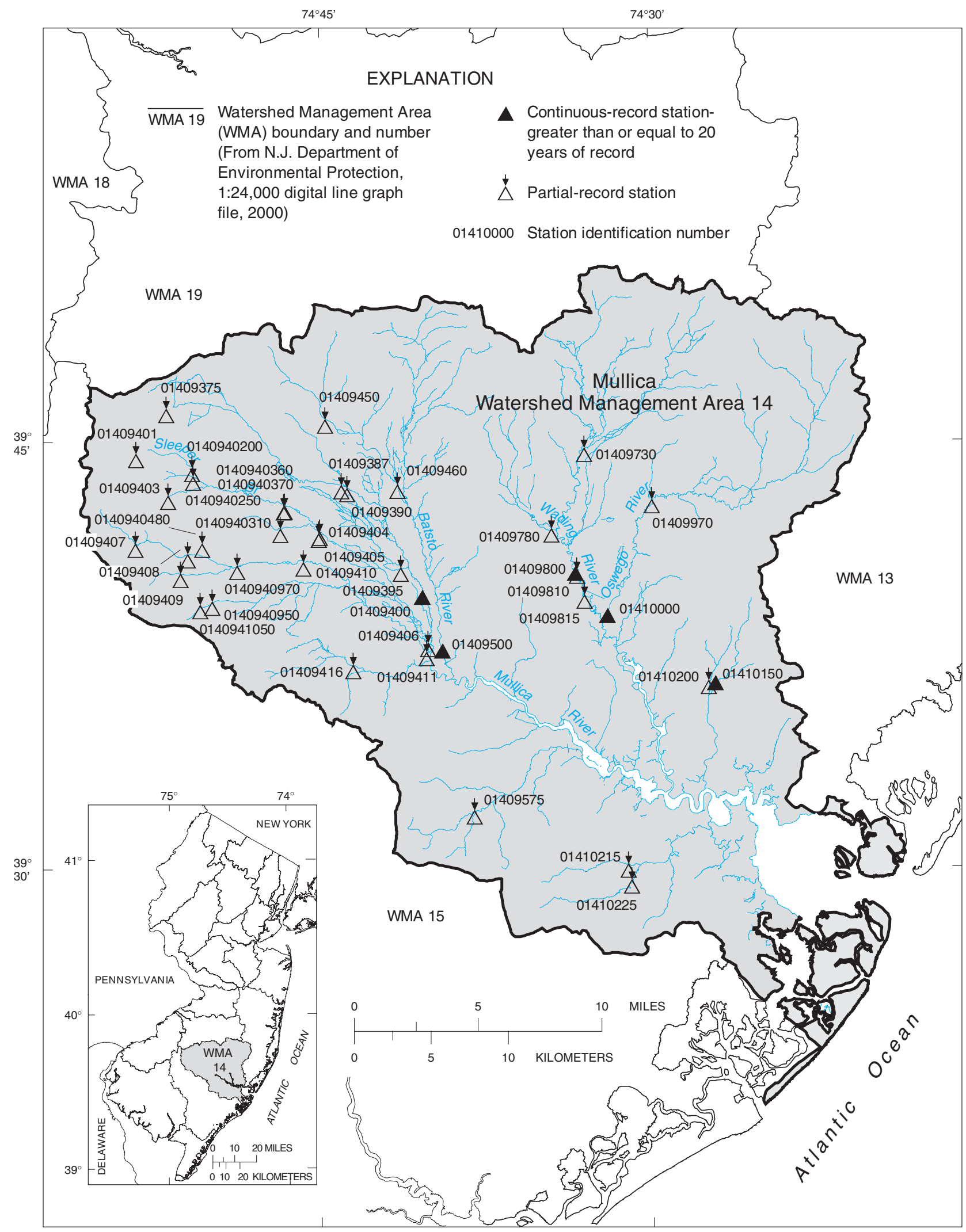

Base from U.S. Geological Survey digital line graph files, 1:24,000

Figure 2-14. Location of streamflow-gaging stations in Watershed Management Area 14 (Mullica) in New Jersey. 


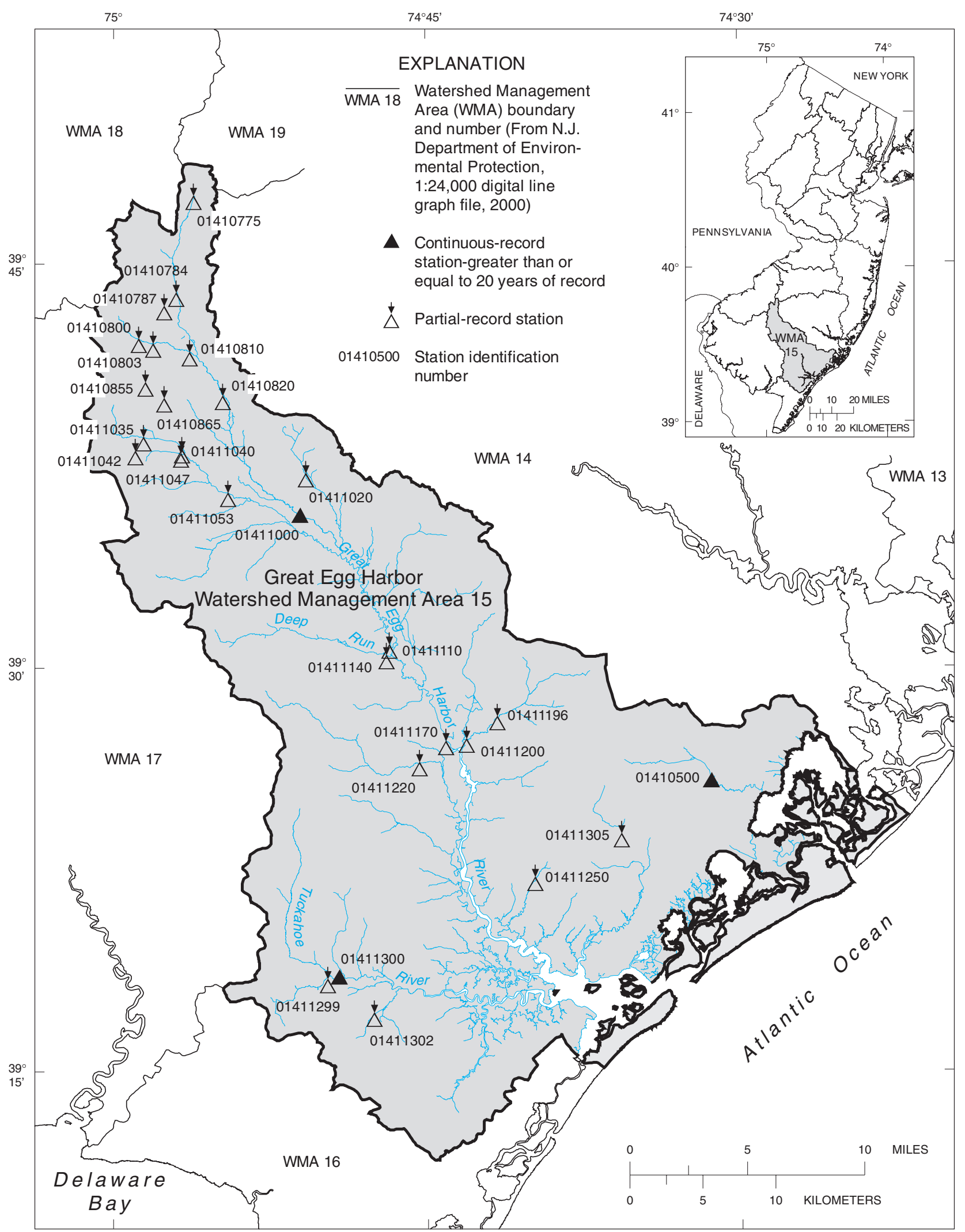

Base from U.S. Geological Survey digital line graph files, 1:24,000

Figure 2-15. Location of streamflow-gaging stations in Watershed Management Area 15 (Great Egg Harbor) in New Jersey. 


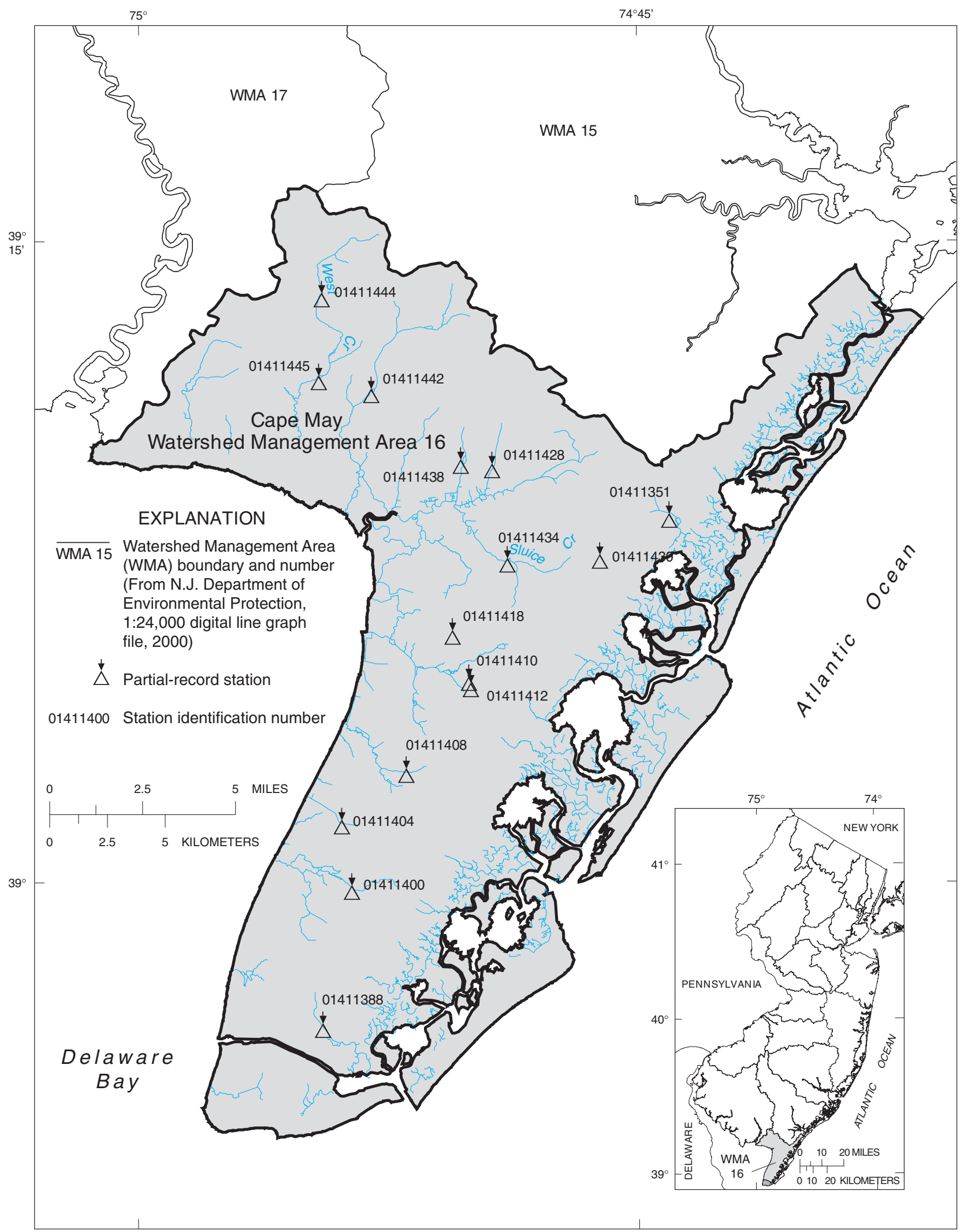

Base from U.S. Geological Survey digital line graph files, 1:24,000

Figure 2-16. Location of streamflow-gaging stations in Watershed Management Area 16 (Cape May) in New Jersey. 


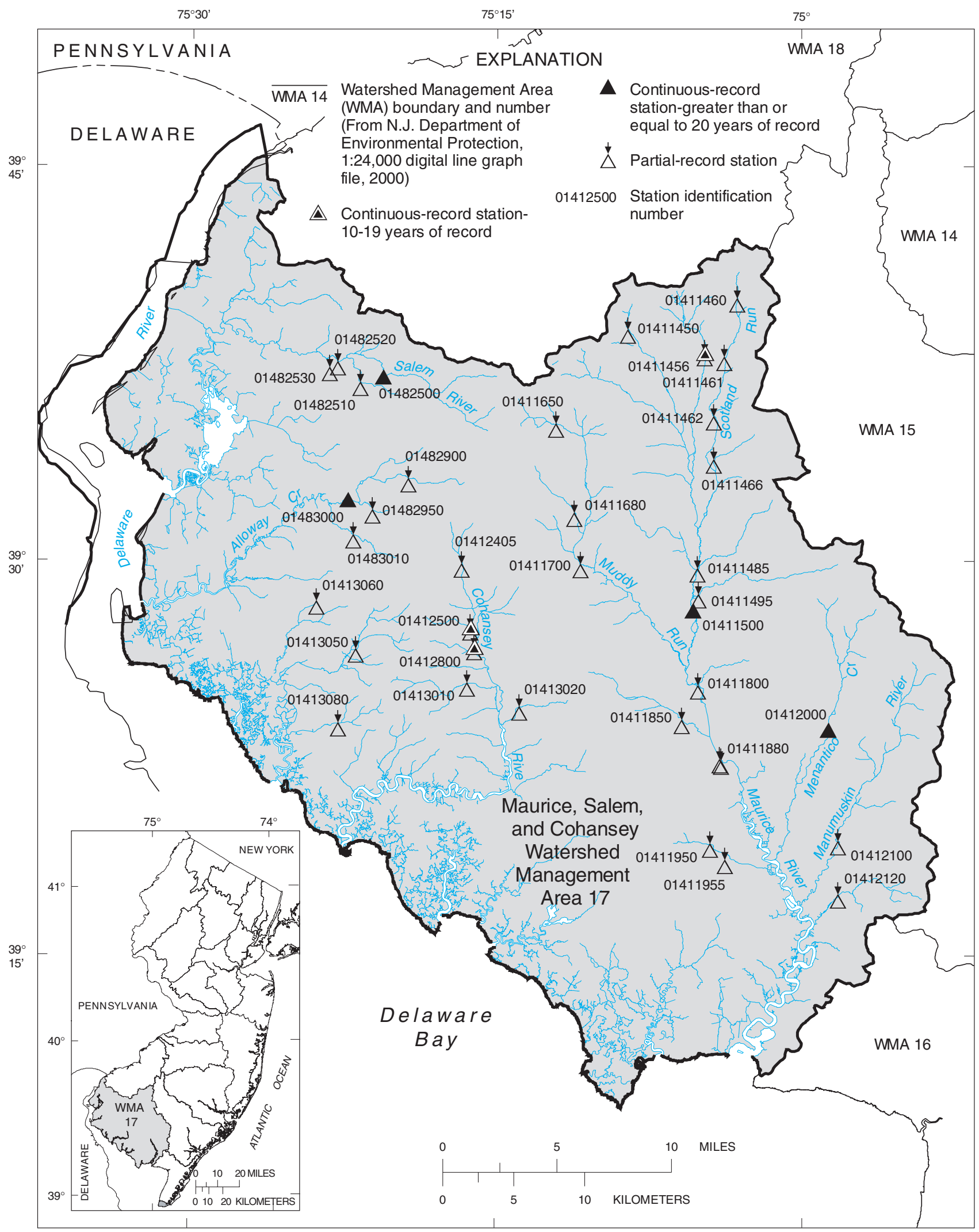

Base from U.S. Geological Survey digital line graph files, 1:24,000

Figure 2-17. Location of streamflow-gaging stations in Watershed Management Area 17 (Maurice, Salem, and Cohansey) in New Jersey. 


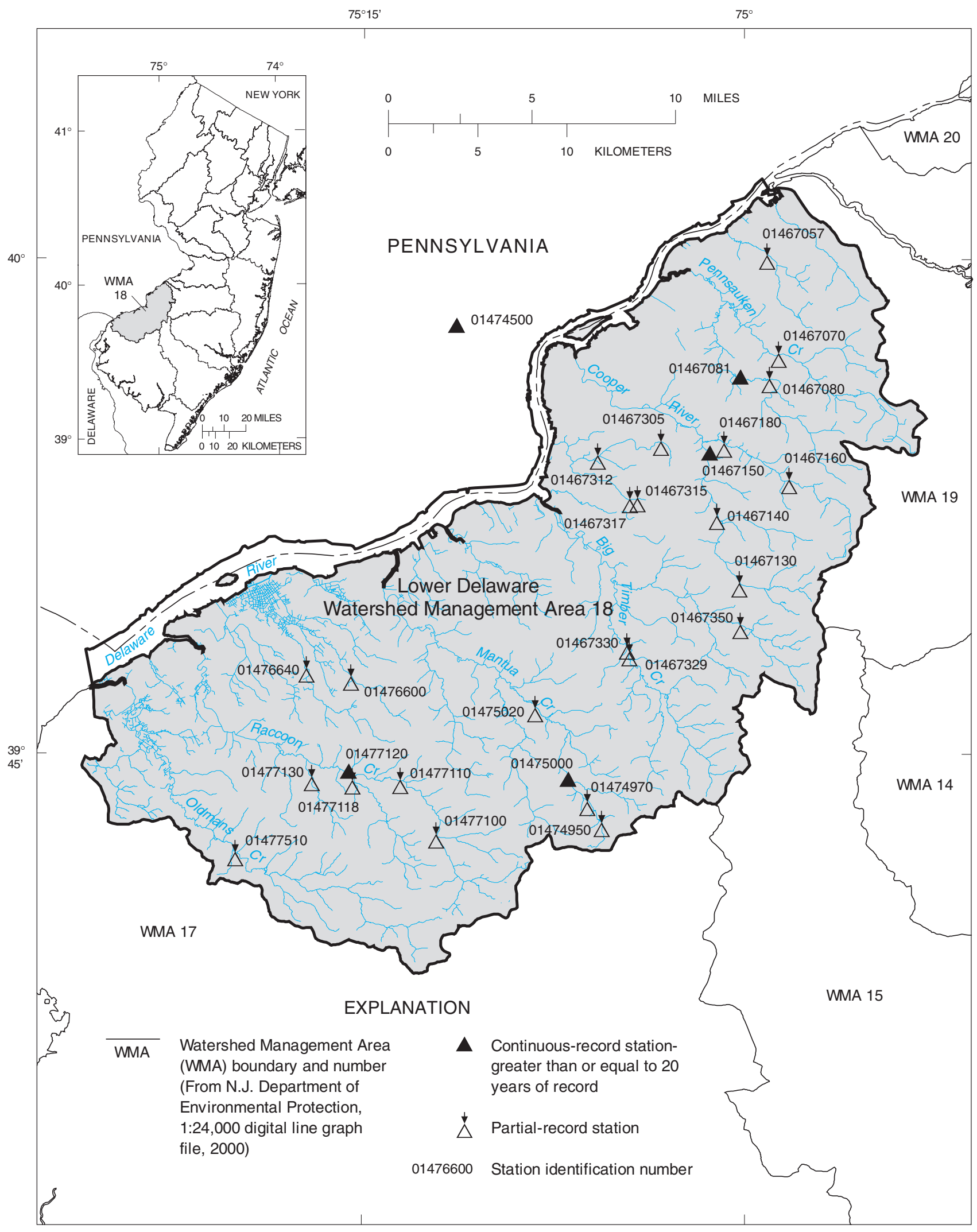

Base from U.S. Geological Survey digital line graph files, 1:24,000

Figure 2-18. Location of streamflow-gaging stations in Watershed Management Area 18 (Lower Delaware) in New Jersey and in Pennsylvania. 


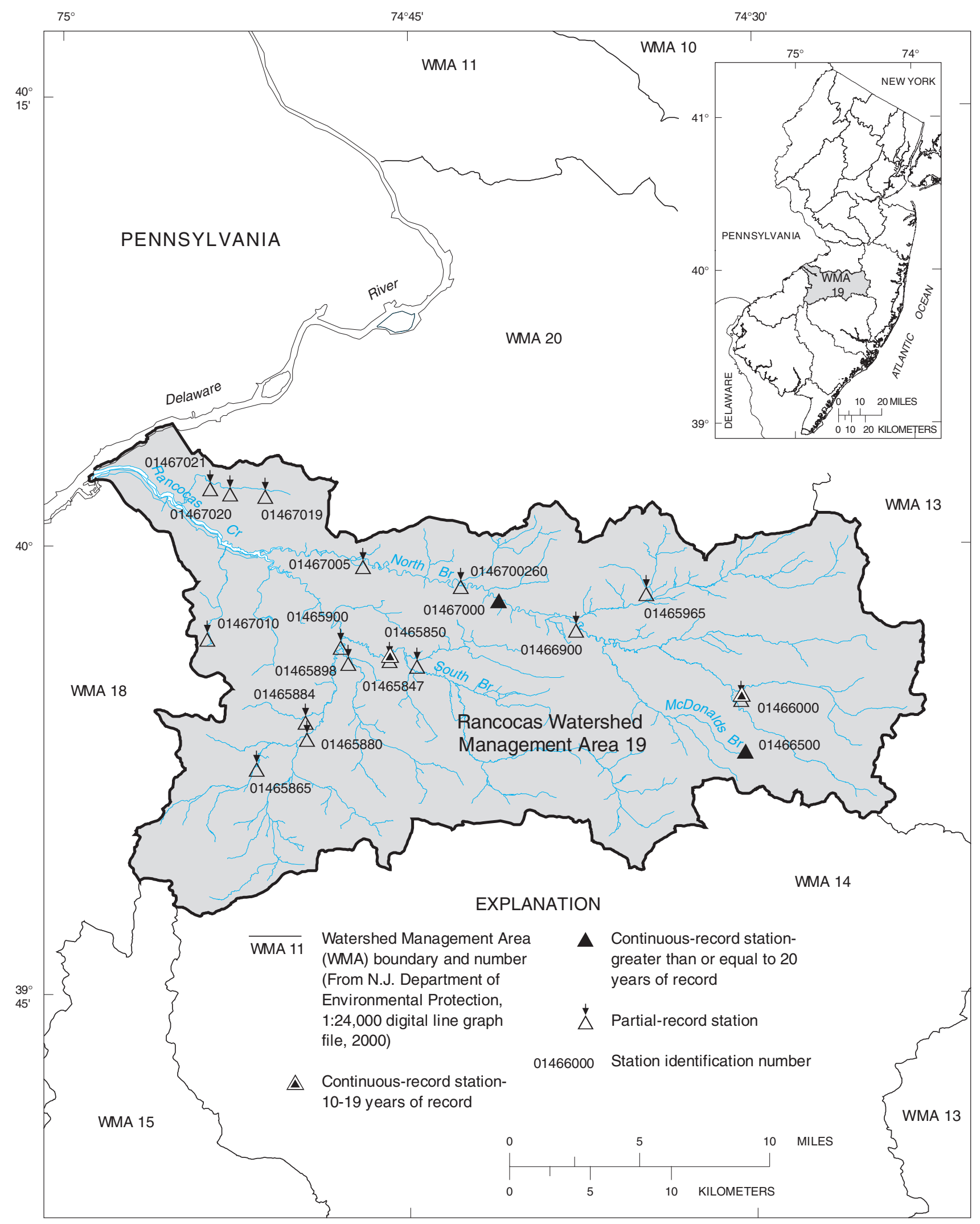

Base from U.S. Geological Survey

digital line graph files, 1:24,000

Figure 2-19. Location of streamflow-gaging stations in Watershed Management Area 19 (Rancocas) in New Jersey. 


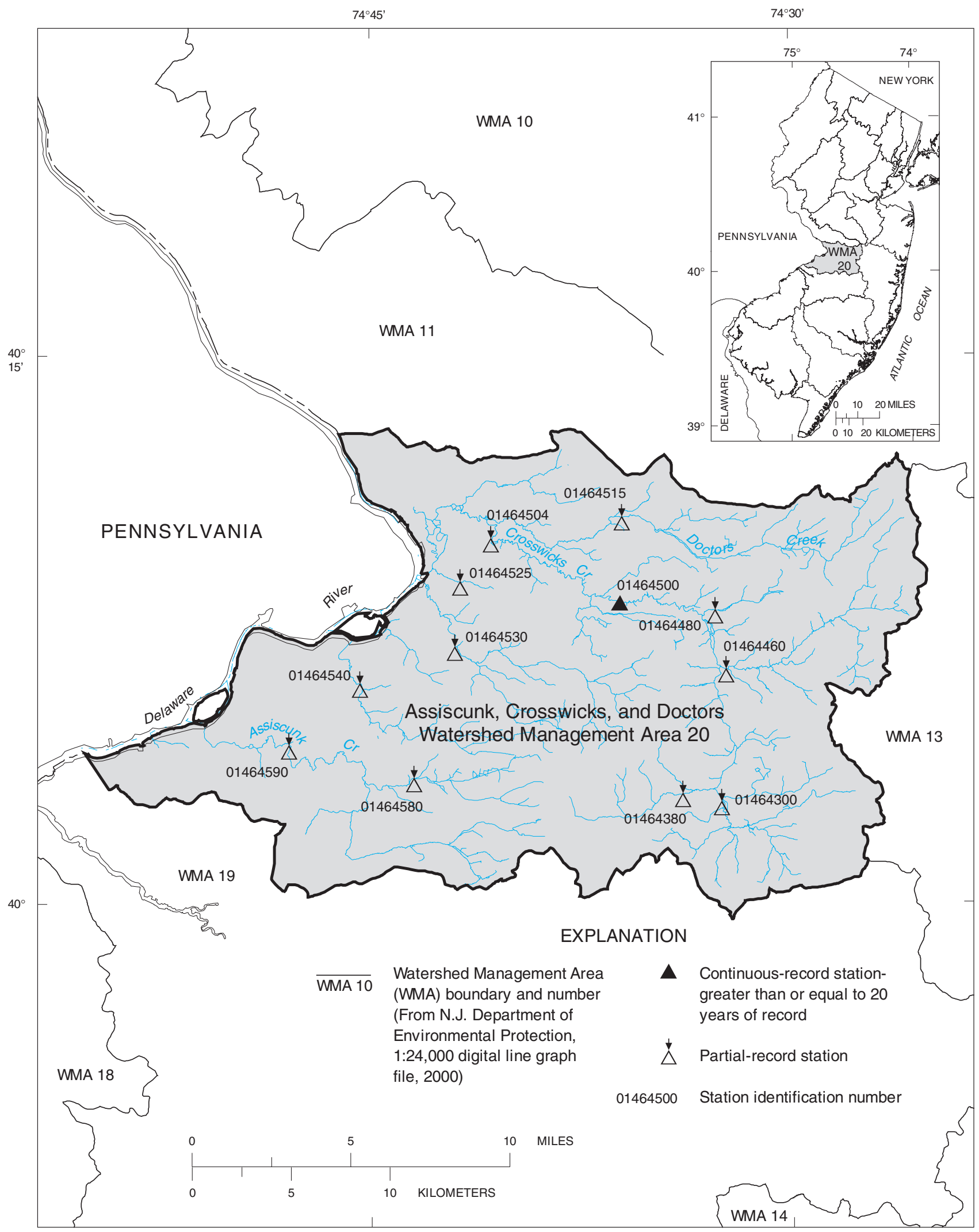

Base from U.S. Geological Survey digital line graph files, 1:24,000

Figure 2-20. Location of streamflow-gaging stations in Watershed Management Area 20 (Assiscunk, Crosswicks, and Doctors) in New Jersey. 

Appendix 3 


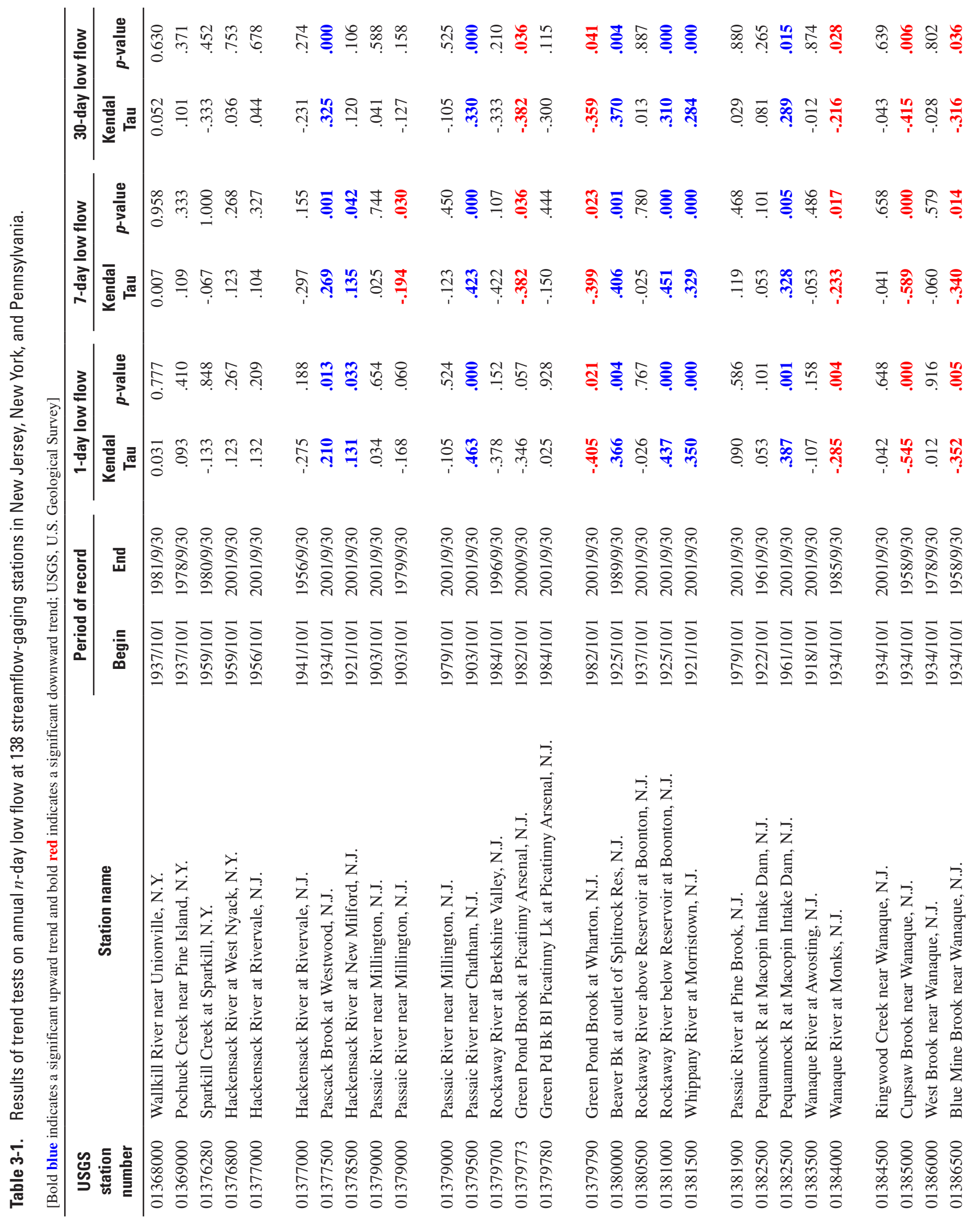




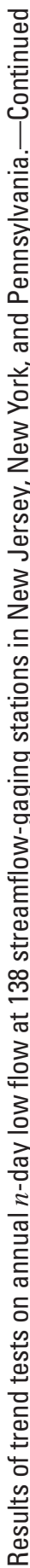

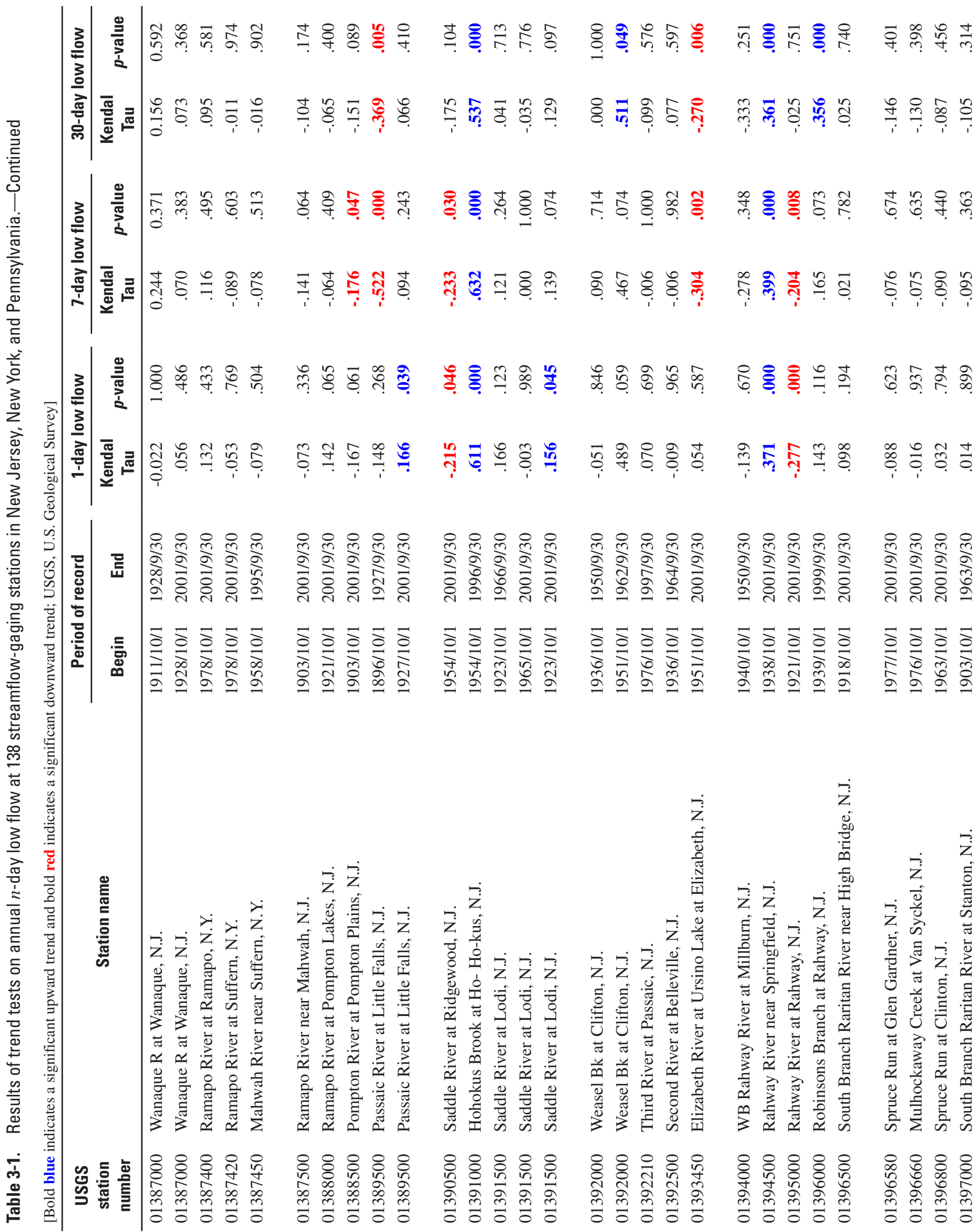




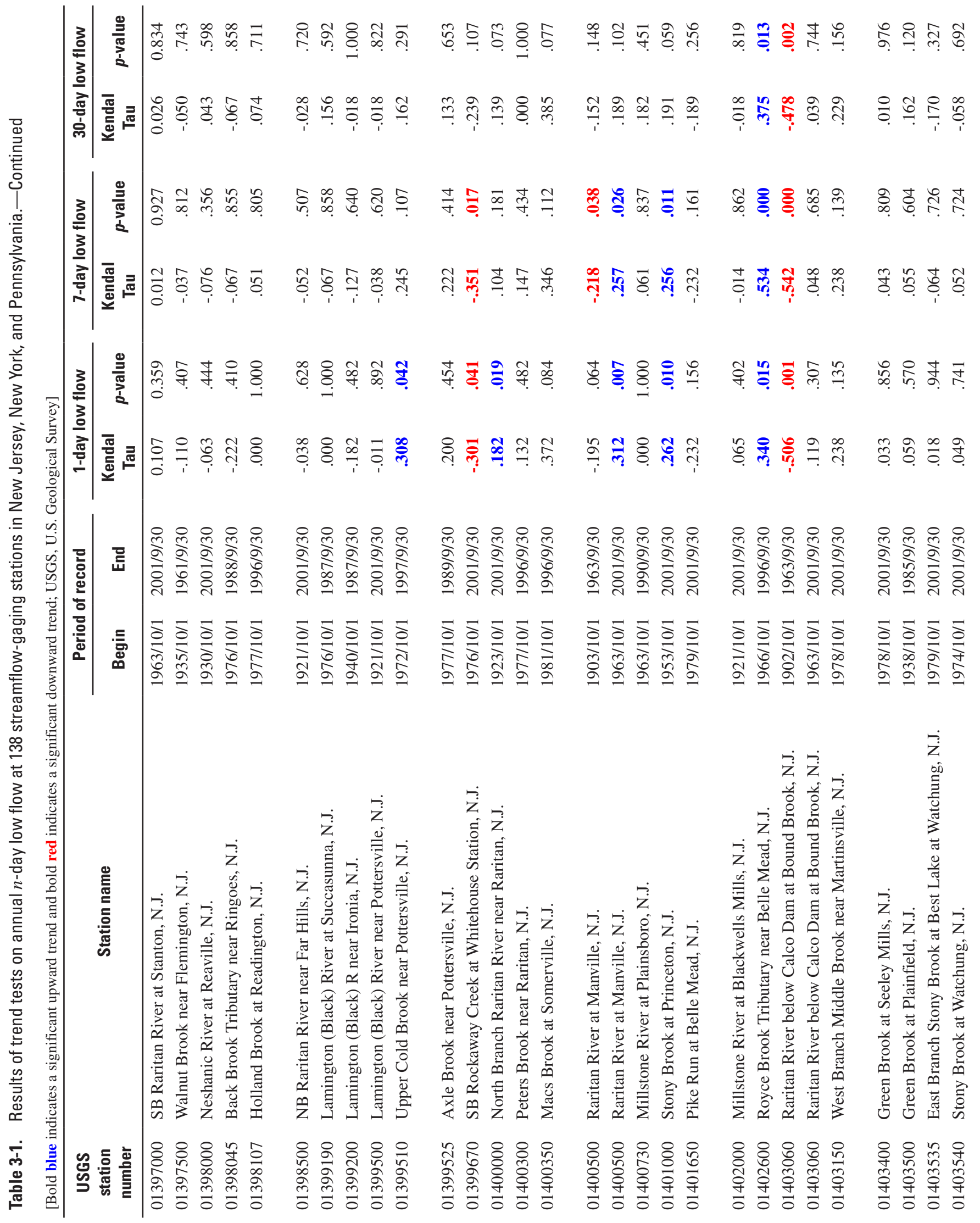




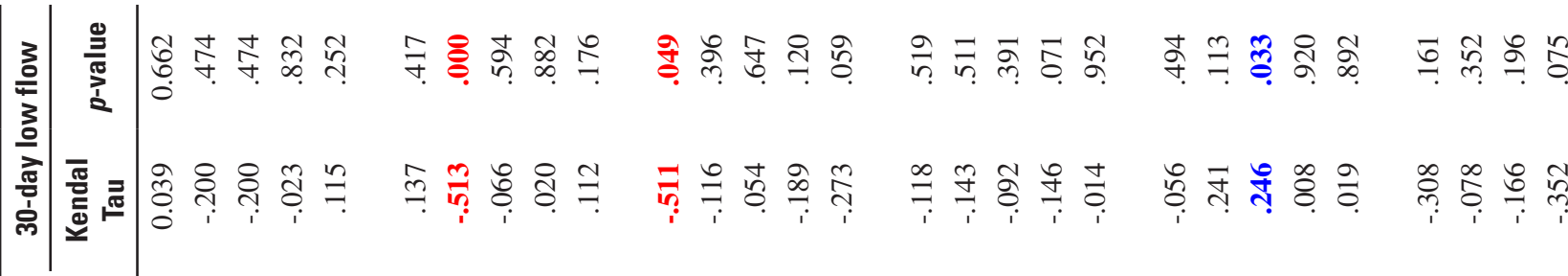

每

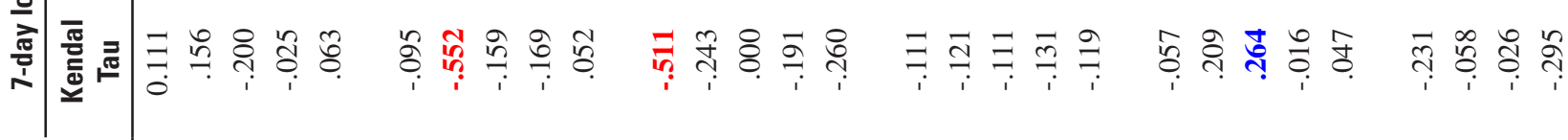

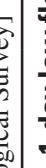

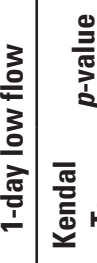

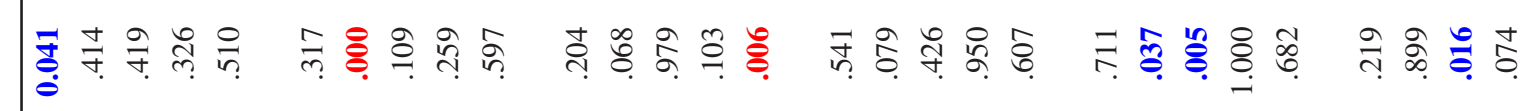

츤

총 तิ

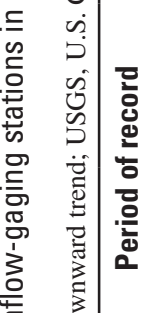

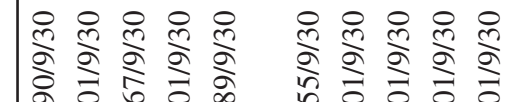

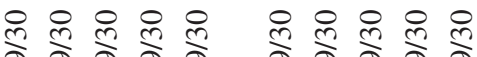

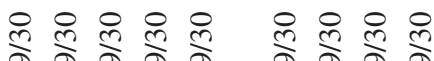

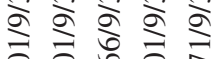

बे के ईू ई

बे बे बे

रे रे रे

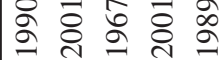

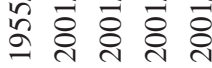

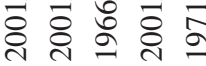

œ

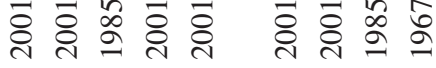

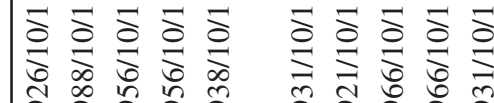

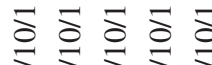

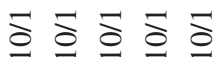

๖े

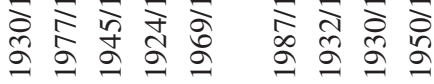

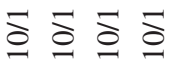

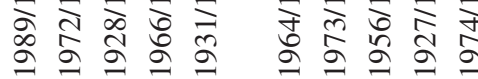

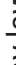

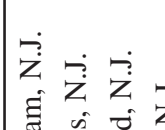

홇

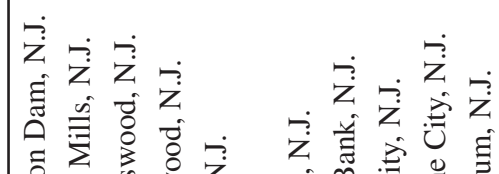

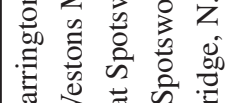

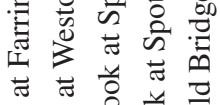

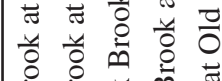

ติ

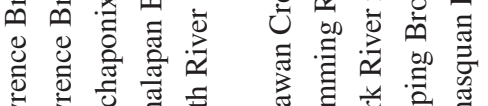

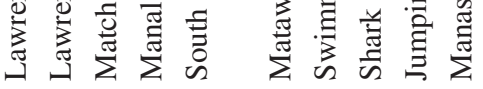

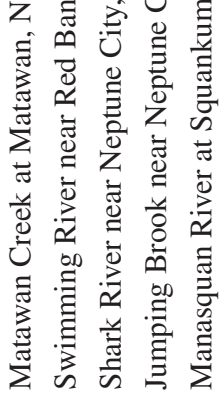

\&

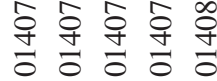

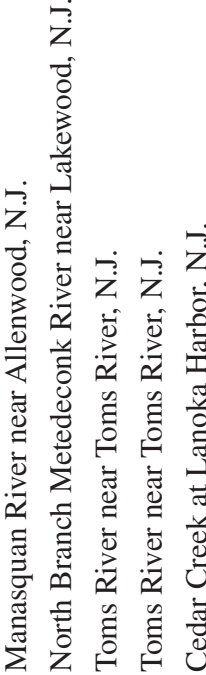

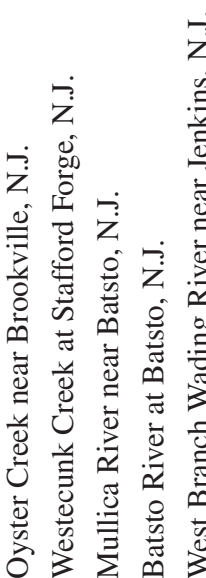

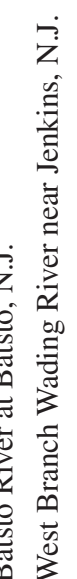

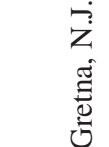

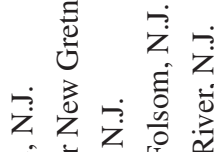

仓ี

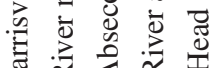

氜选远

芯氙芯

एँ

य च U

엥

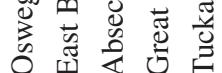

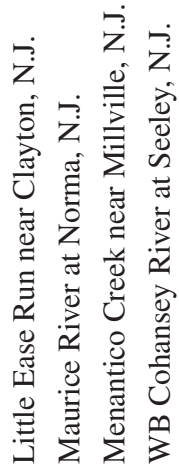

సิ ণ

そิ \& 8 \&

\&

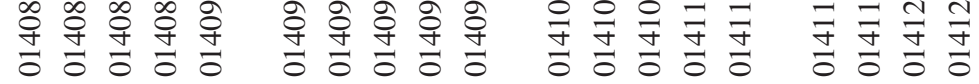




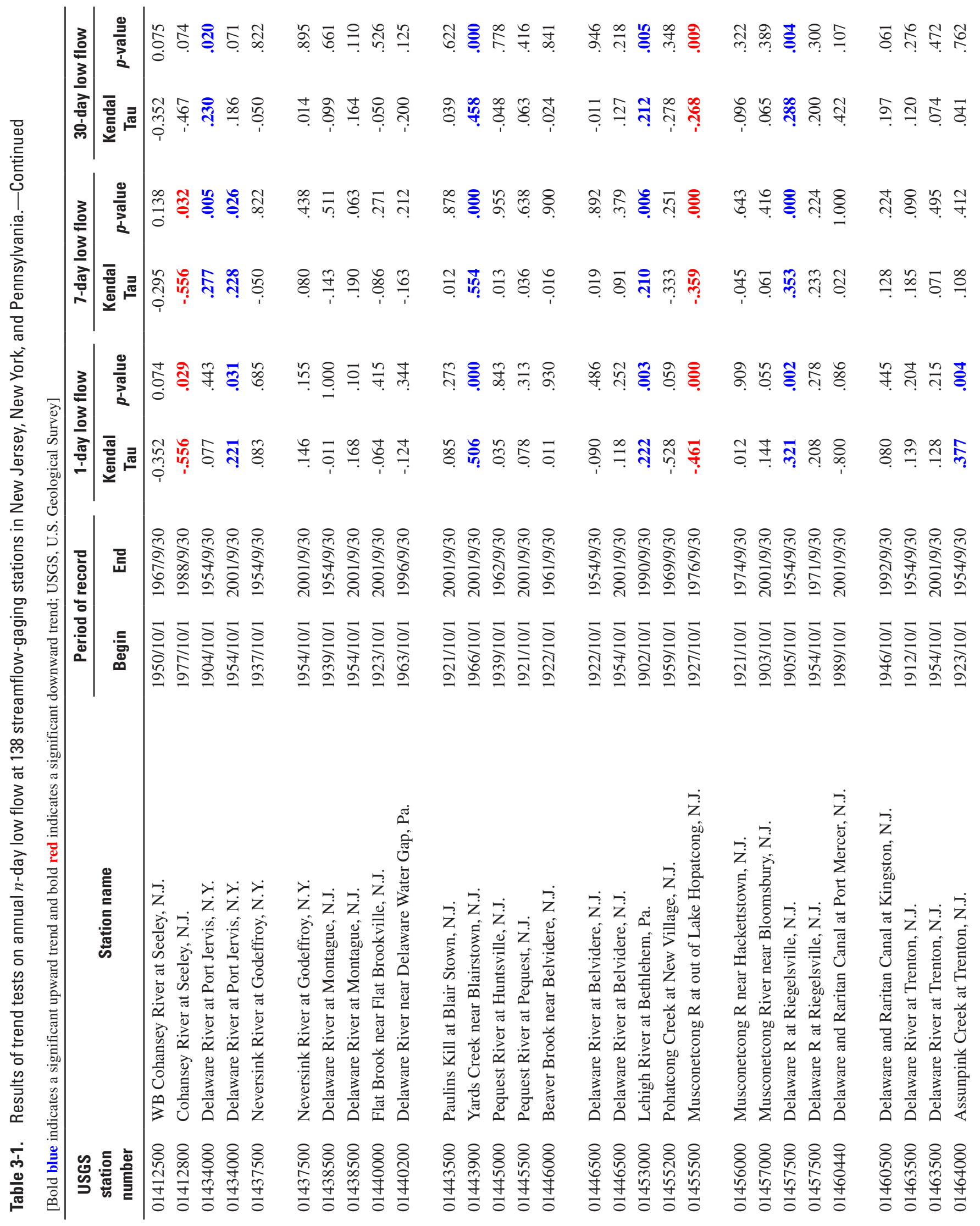




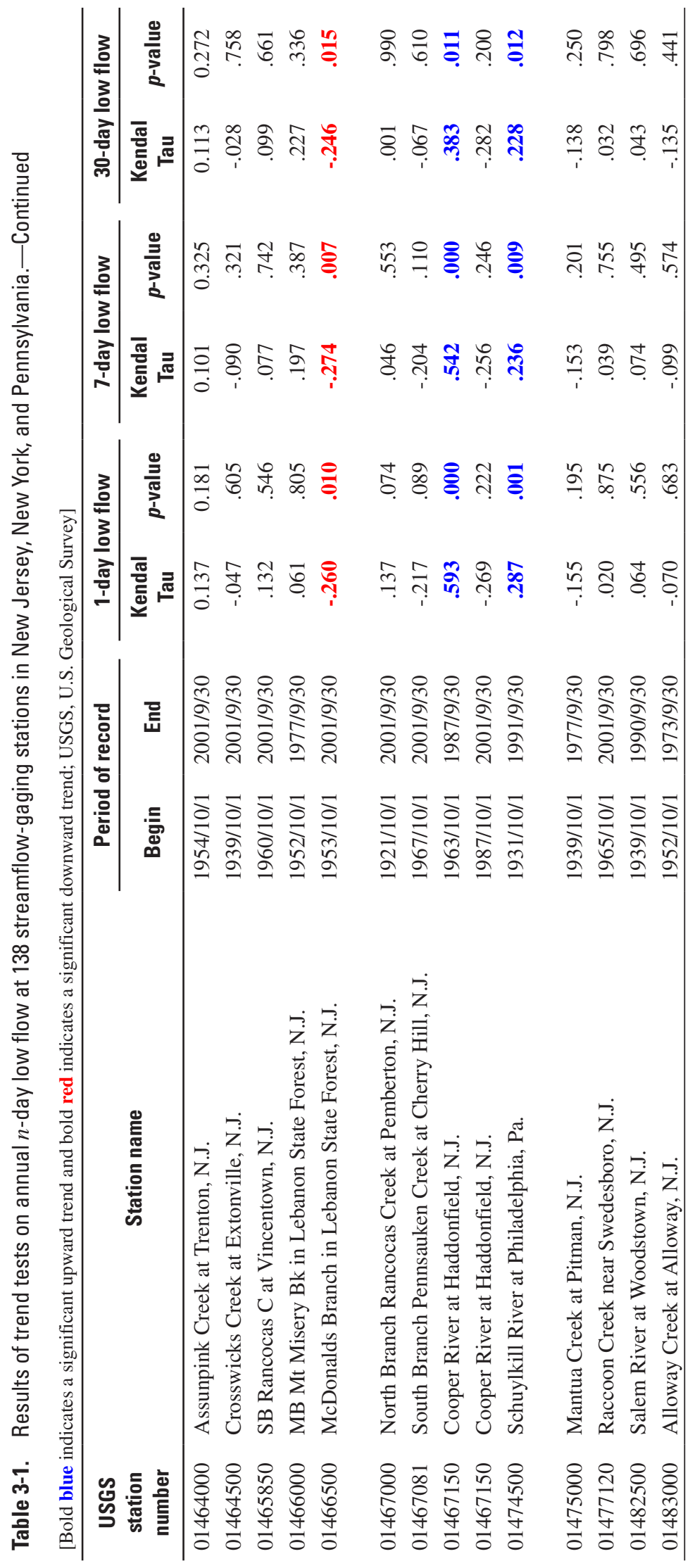




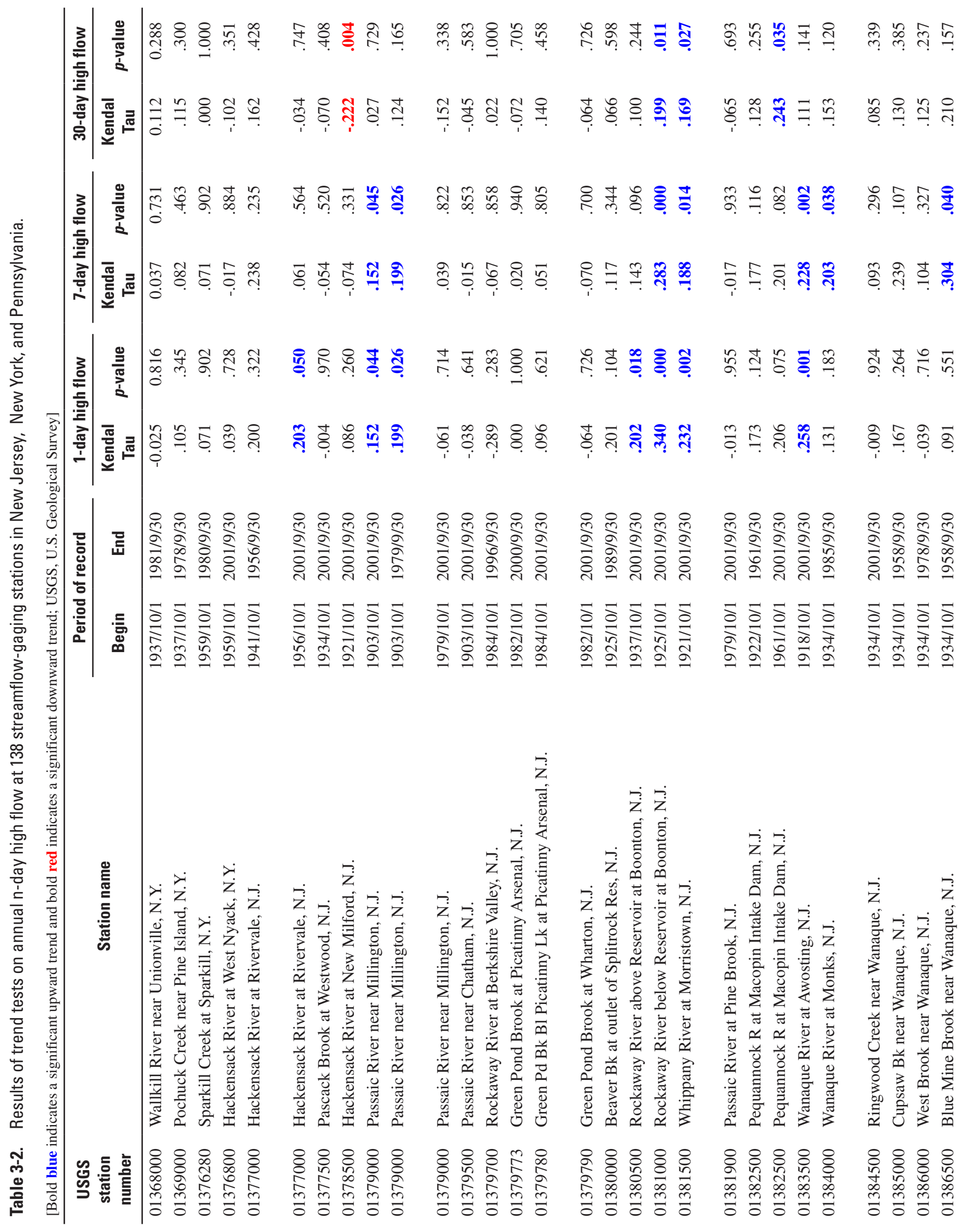




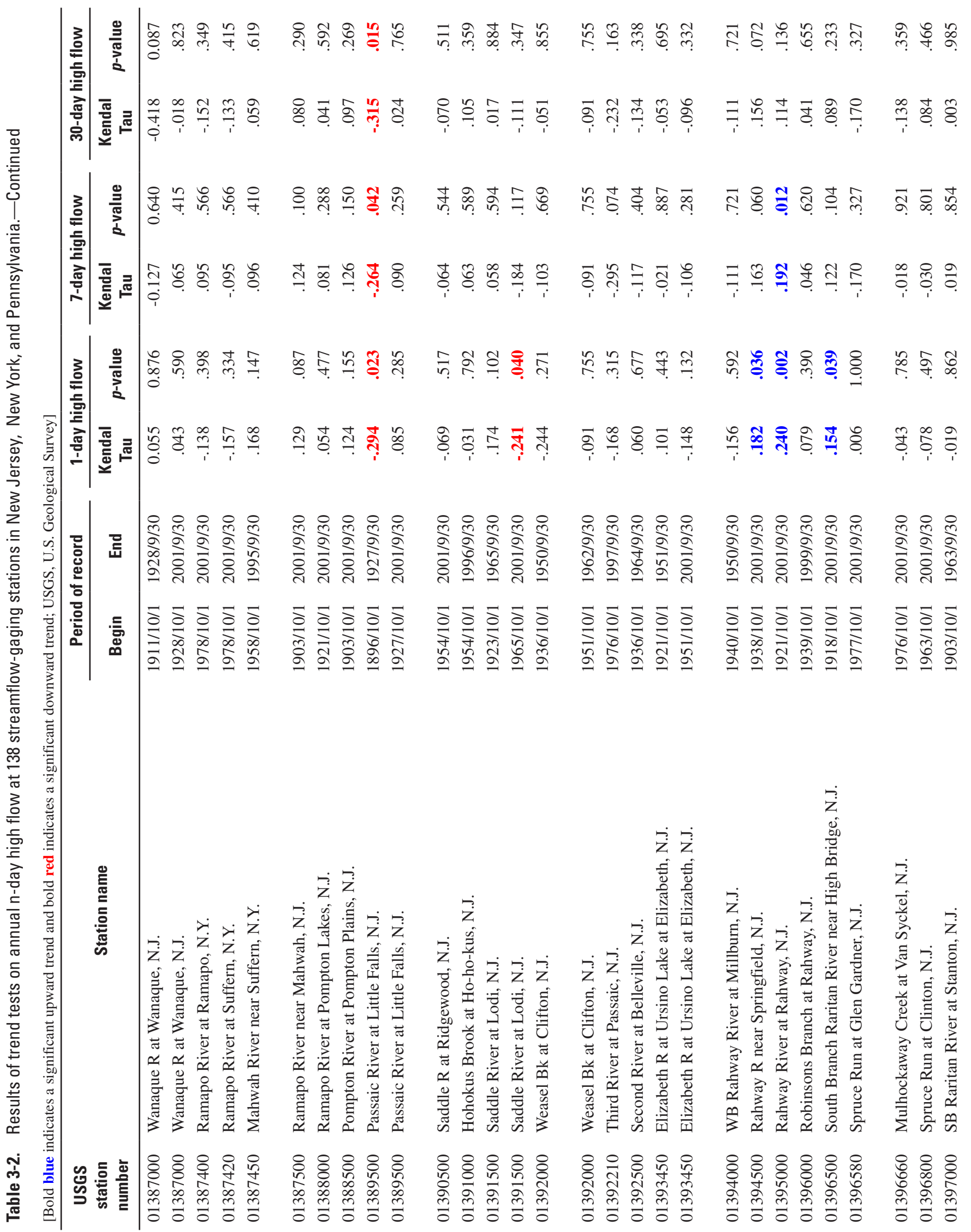




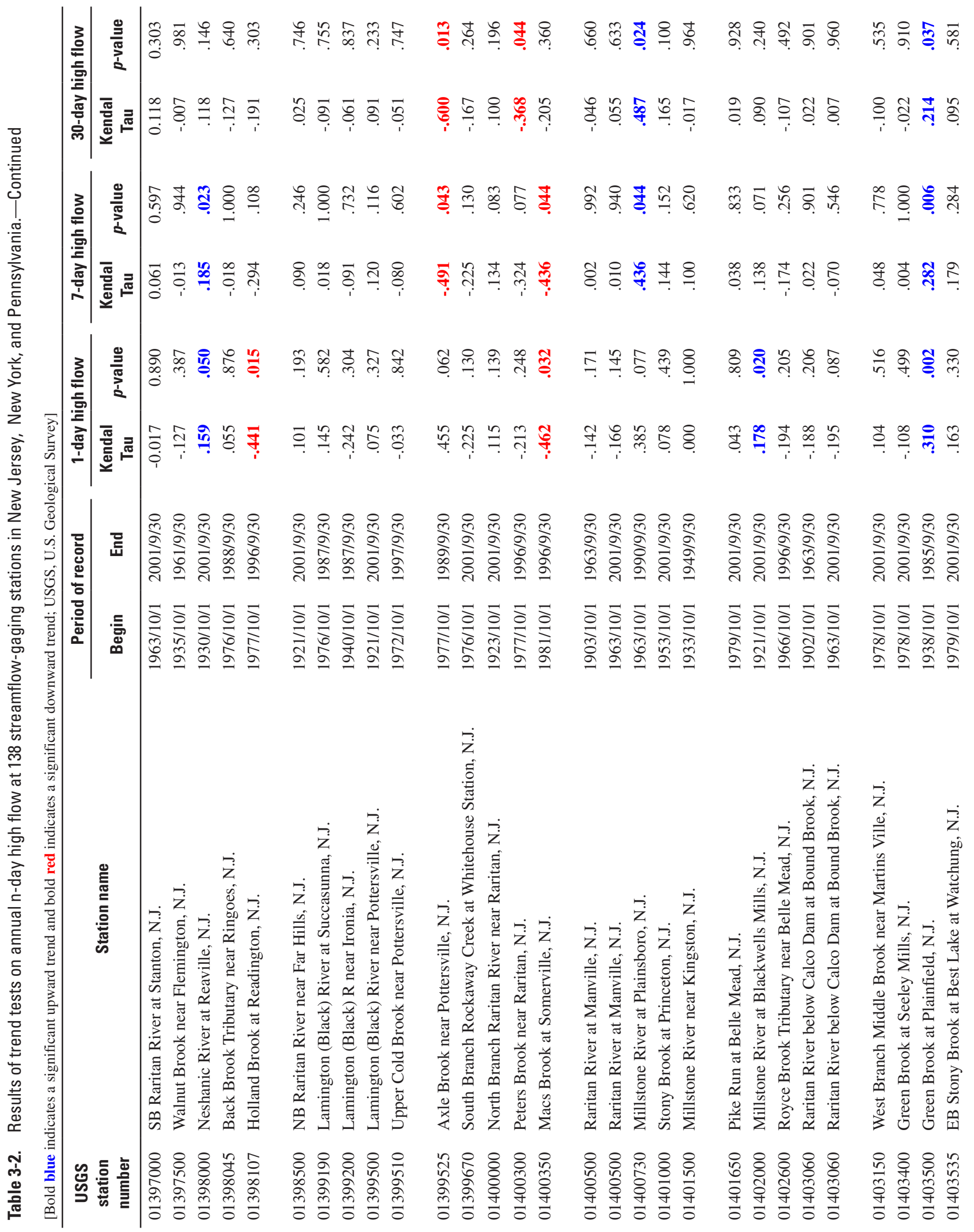




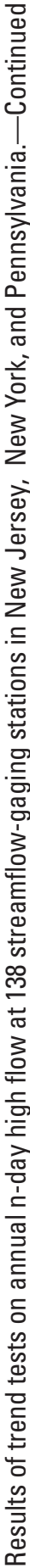

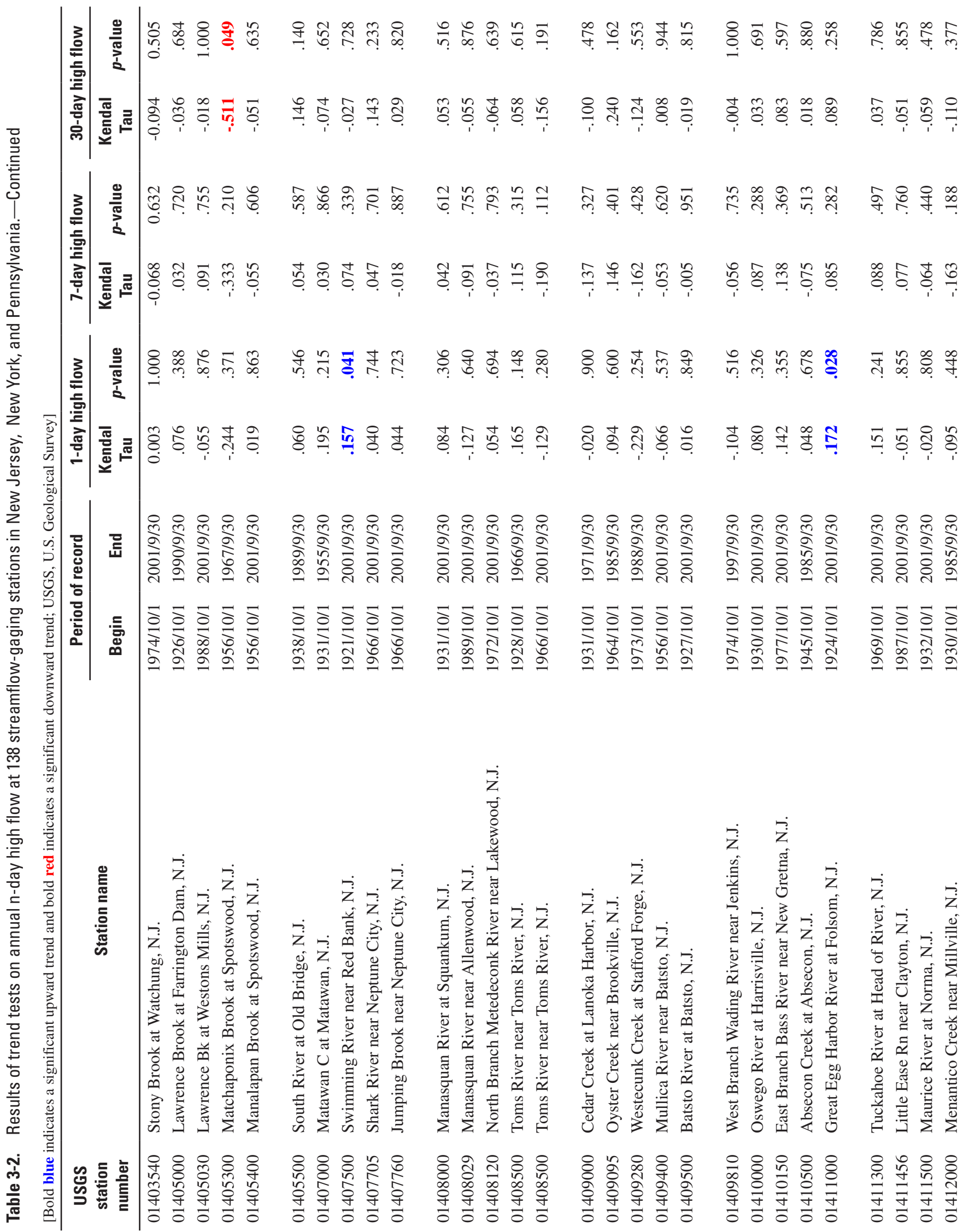




\begin{tabular}{|c|c|c|c|c|c|c|c|}
\hline$\underset{\substack{3\\
}}{2}$ & $\frac{0}{\frac{0}{E}}$ & 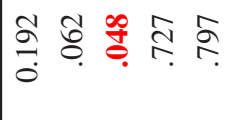 & ڤ్రి & 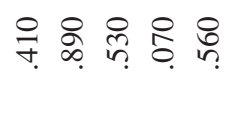 & 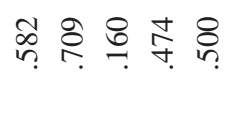 & ஓ \& & 宅 \\
\hline 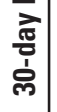 & 嵒 & 虫 & 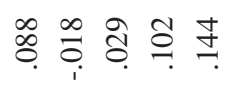 & ఫ্ & ஜֶ. & 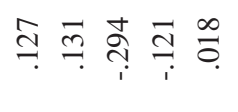 & 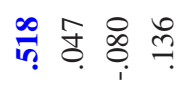 \\
\hline$\stackrel{3}{30}$ & 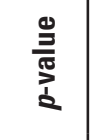 & ש̂. & 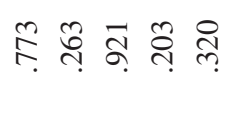 & 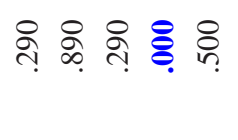 & \& & 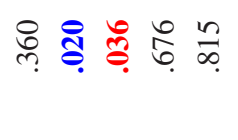 & 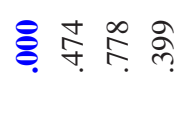 \\
\hline 产 & 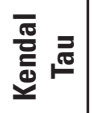 & 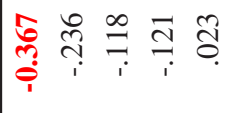 & 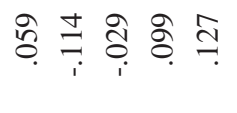 & oै & 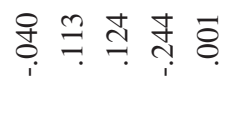 & 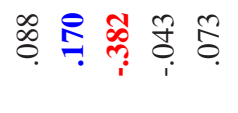 & 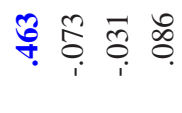 \\
\hline$\stackrel{3}{0}$ & 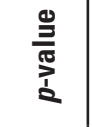 & 笑 & 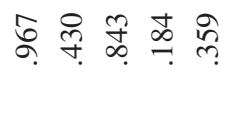 & : & 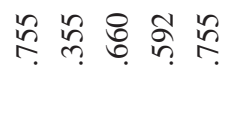 & 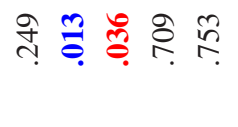 & 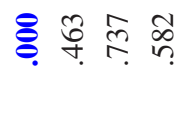 \\
\hline 产 & 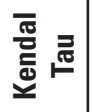 & 象 & $\stackrel{n}{0}_{i}^{\infty} \underset{i}{\infty} \underset{i}{\infty} \stackrel{\infty}{=} \stackrel{\infty}{=}$ & 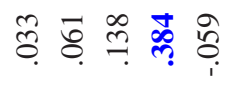 & है & 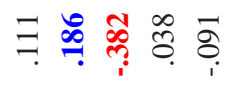 & ํ. \\
\hline 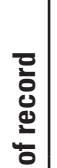 & 总 & 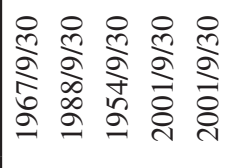 & 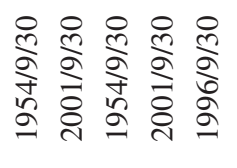 & 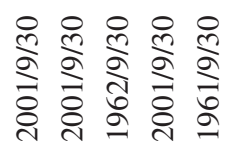 & 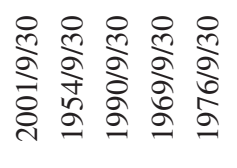 & 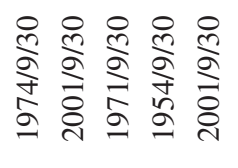 & 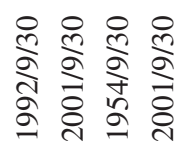 \\
\hline . & 言 & 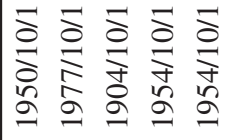 & 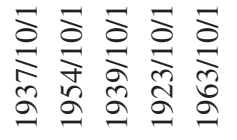 & 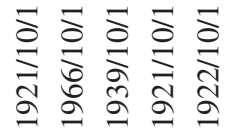 & 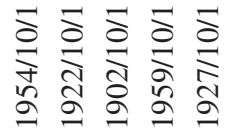 & 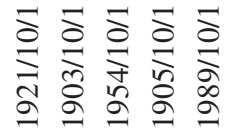 & 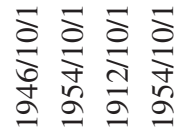 \\
\hline
\end{tabular}

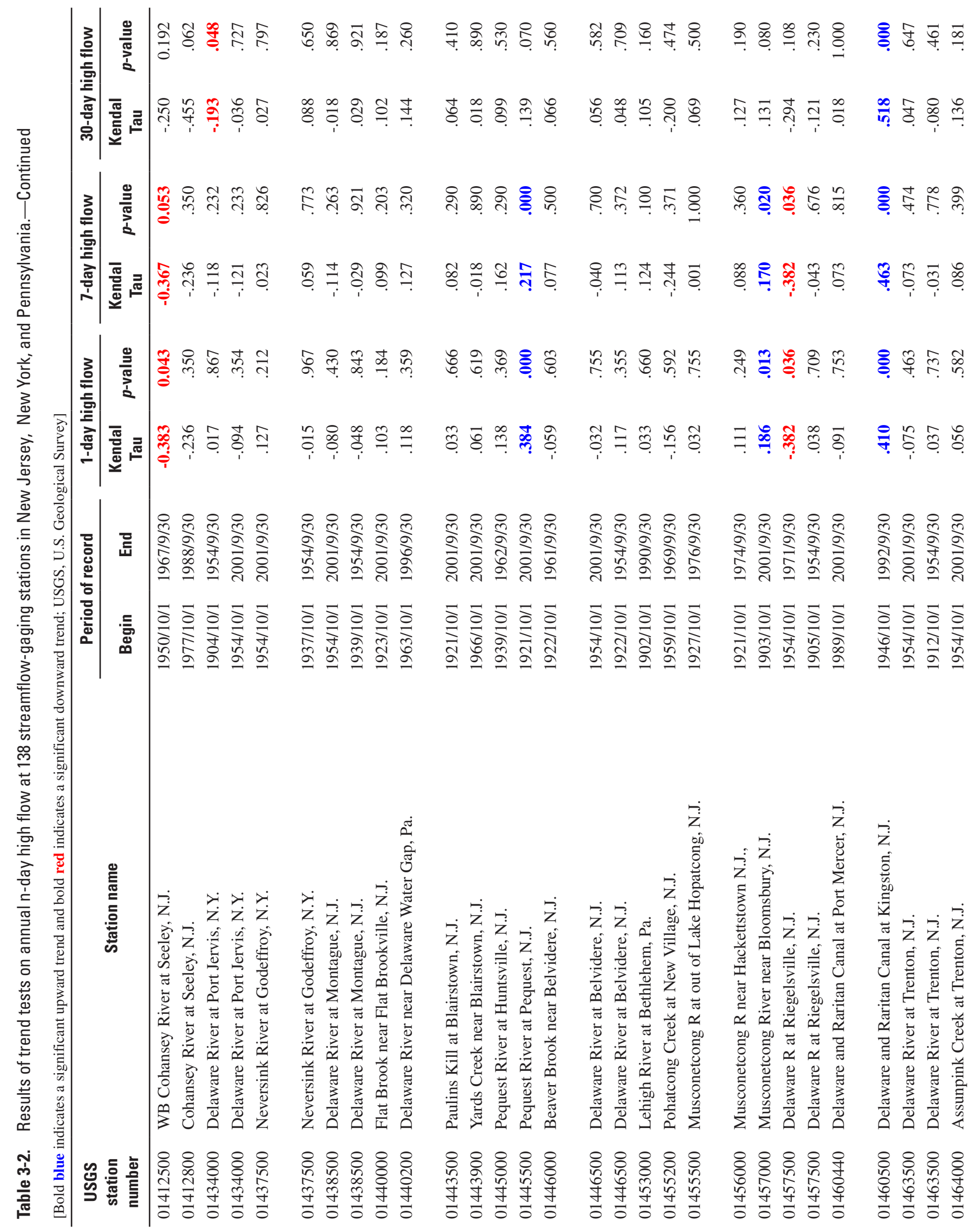




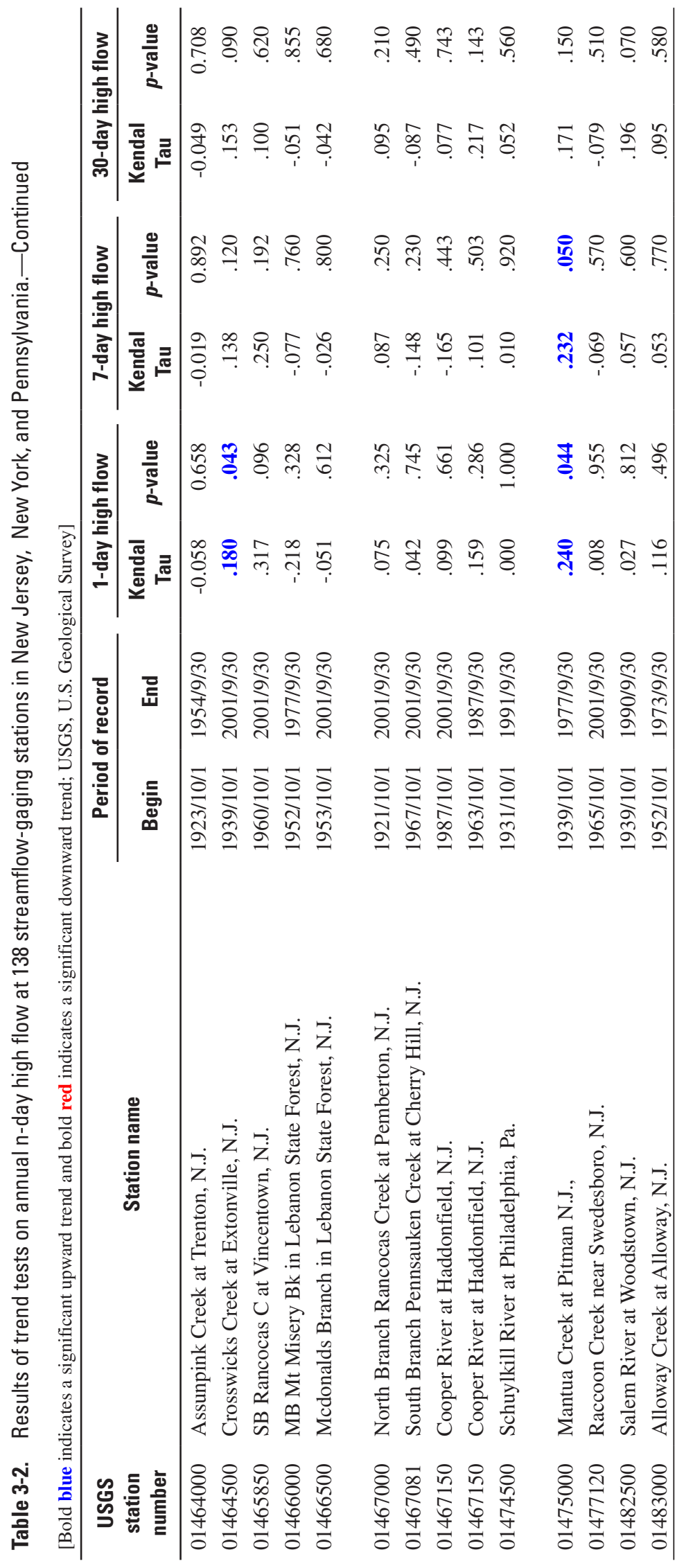


For additional information, write to:

Director

U.S. Geological Survey

New Jersey Water Science Center

Mountain View Office Park

810 Bear Tavern Rd., Suite 206

West Trenton, NJ 08628

or visit our Web site at:

http://nj.usgs.gov/ 